\title{
Discovery of a New Class of Macrocyclic Antagonists to the
}

\section{Human Motilin Receptor}

Eric Marsault,* Hamid R. Hoveyda, Mark L. Peterson, Carl Saint-Louis, Annick Landry, Martin Vézina, Luc Ouellet, Zhigang Wang, Mahesh Ramaseshan, Sylvie Beaubien, Kamel Benakli, Sophie Beauchemin, Robert Déziel, "Theo Peeters, and Graeme L. Fraser

Tranzyme Pharma Inc., 3001, 12e avenue Nord, Sherbrooke, PQ, Canada, J1H 5N4

\section{Supporting Information}

\section{TABLE OF CONTENTS}

1. General Procedure for macrocycle synthesis using RCM cyclative release $(\operatorname{method} B) \quad 2$

2. Synthesis of tether components of macrocycles 5

$\begin{array}{lr}\text { 3. Details of macrocycles synthesis } & 14\end{array}$

4. Characterization of Final Macrocycles 2

a. Analytical methods $\quad 21$

b. LC/MS and HRMS data 22

c. NMR characterization of selected macrocycles 24

$\begin{array}{lr}\text { 5. Biological assays } & 27\end{array}$

Appendix 1. LC-MS and NMR raw data for tether components $\begin{array}{ll}\text { of macrocycles } & 30\end{array}$

Appendix 2. Chromatograms and MS spectra for final macrocycles 39

Appendix $3 .{ }^{1} \mathrm{H}$ and ${ }^{13} \mathrm{C}$ NMR spectra of selected final macrocycles $\quad 83$ 


\section{General Procedure for macrocycle synthesis using method B}

Note: Typically, the Tyr side chain was protected as a tBu ester.

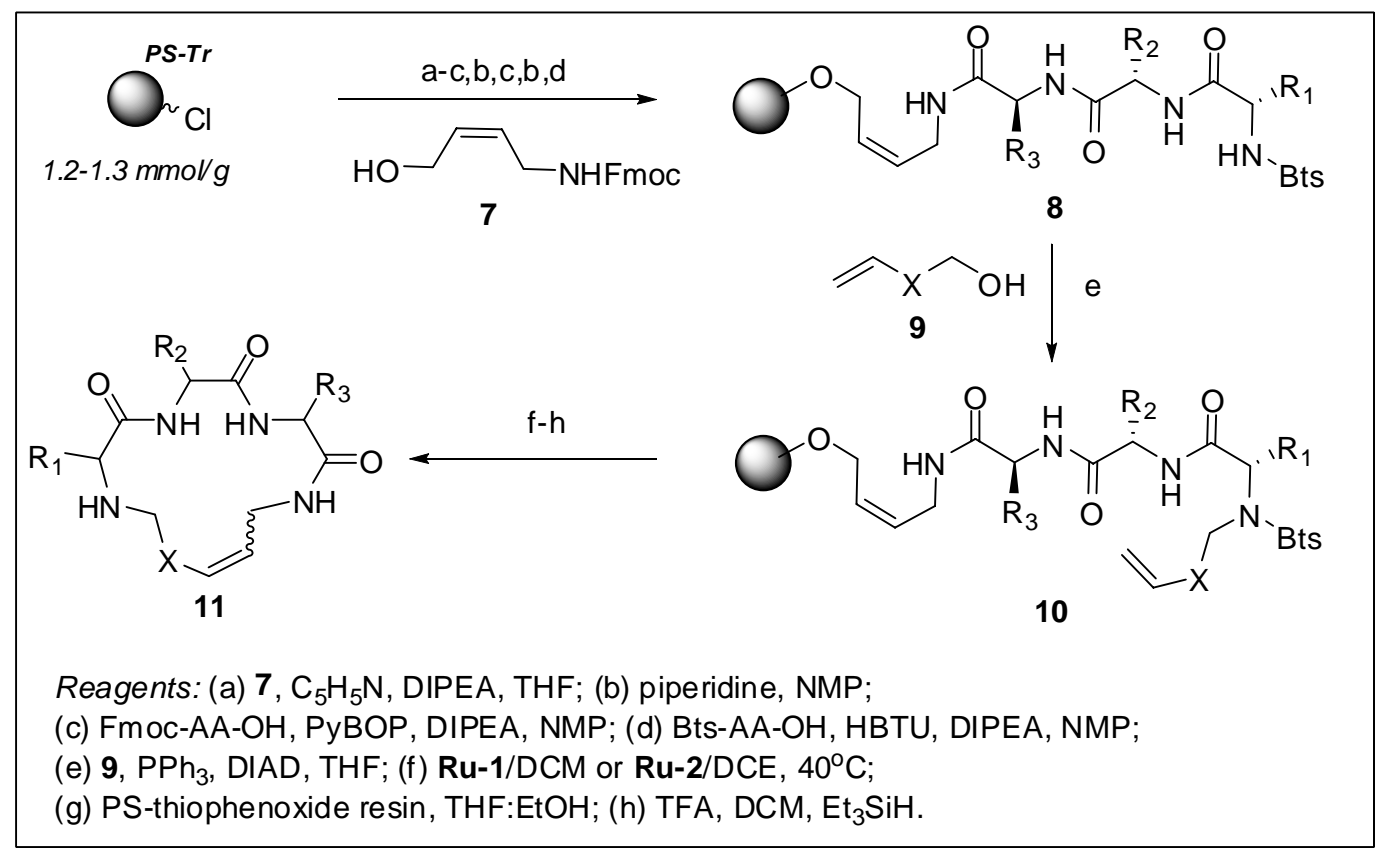

\section{a. Loading of RCM Linker on PS-TrtCl resin}

In a flame-dried round-bottom flask equipped with a magnetic stirrer and a condenser, was added the $\mathrm{TrtCl}$ resin under nitrogen, followed by anhydrous THF $(10 \mathrm{~mL} / \mathrm{g}$ of resin). Anhydrous pyridine (10 eq. with respect to the loading of the resin) and anhydrous DIPEA (5 eq.) were then added, followed promptly by the addition of the linker (5 eq.). The mixture was stirred gently at $60{ }^{\circ} \mathrm{C}$ under nitrogen for $24 \mathrm{~h}$. After cooling, the flask contents was transferred into a solid-phase peptide synthesis (SPPS) vessel for resin capping/washing steps. Resin wash procedure: $3 \times$ DCM/MeOH/DIPEA (17:2:1), 3x DCM, 2x NMP, 3x DCM, $1 \mathrm{x} \mathrm{Et}_{2} \mathrm{O}$. Resin was then dried in vacuo.

\section{b. Fmoc Deprotection of Linker}

A solution of $20 \%$ piperidine in NMP $(25 \mathrm{~mL} / \mathrm{g}$ of resin) was added to the Fmoc-protected resin in a SPPS vessel, and the mixture was agitated $2 \times 15$ min on an orbital shaker. Resin wash: 4x NMP.

\section{c. Coupling of $\mathrm{AA}_{3}$}

$\mathrm{FmocAA}_{3}$ (5 eq.) was introduced into a glass jar followed by NMP to make up a $0.2 \mathrm{M}$ solution. To this mixture was added PyBOP (5 eq.), and the resultant mixture was agitated until a homogenous solution was obtained. At this point, DIPEA (10 eq.) was added, followed by a quick agitation $(5 \mathrm{sec})$, and the mixture was transferred to a SPPS vessel that contains the Fmoc-deprotected linker resin. The SPPS vessel was agitated on an orbital shaker overnight. Resin wash procedure: 1x NMP, DCM, NMP, 2 x [(MeOH/DCM), (MeOH/THF)], 2x DCM. Test the completion of reaction using a qualitative ninhydrin test 
See step 3.b. above.

d. Deprotection of Fmoc- $A A_{3}$

e. Coupling of $\mathrm{AA}_{2}$

See step 3.c. above.

f. Deprotection of Fmoc-A $A_{2}$

See step 3.b. above.

g. Coupling of Bts- $A A_{1}$

Bts-A $A_{1}-\mathrm{OH}$ (5 eq.) was added into a glass jar followed by $\mathrm{X}$ ml of NMP to make up a $0.2 \mathrm{M}$ solution. To this solution was added HBTU (5 eq.), and the resultant mixture was agitated until a homogenous solution was obtained. At this point, DIPEA (10 eq.) was added, followed by a quick agitation $(5 \mathrm{sec})$, and the resultant mixture was transferred to a SPPS vessel containing the Fmoc-deprotected dipeptide loaded resin. The SPPS vessel was agitated on an orbital shaker overnight. Resin wash procedure: NMP, DCM, NMP, 2x [(MeOH/DCM), (MeOH/THF)], 2x DCM.

\section{h. Tether Attachment Step via Mitsunobu reaction}

The tether alcohol (5 eq. based on the actual loading of the resin) was added into a glass jar, followed by $\mathrm{X} \mathrm{ml}$ of dry THF to make up a $0.2 \mathrm{M}$ solution. To this mixture was added $\mathrm{PPh}_{3}$ and the mixture was agitated until a homogenous solution was obtained. The reagent mixture was transferred to a SPPS vessel containing the tripeptide loaded resin, which was then briefly agitated. DIAD (5 eq.) was then added to the SPPS vessel. The SPPS vessel was then shaken on an orbital overnight. Resin wash procedure: 2x DCM, Toluene, EtOH, Toluene, 2x [(MeOH/DCM), (MeOH/THF)], 2x DCM.

i. Macrocyclization via RCM (macrocycles 14a-c, 14e-j, 15b)

In a flame-dried round-bottom flask equipped with magnetic stirrer, and a condenser, was transferred the alkylated tripeptide (100 $\mathrm{mg}, 0.06 \mathrm{mmol}$ based on effective loading), followed by the RCM catalyst (10 mol\%), followed by DCM (Grubbs' second generation catalyst) or DCE (Hoveyda's second generation catalyst). The mixture was gently stirred at $40{ }^{\circ} \mathrm{C}$ under nitrogen for $24 \mathrm{~h}$. The mixture was then allowed to cool down to room temperature, then ca. 50 eq. of ethyl vinyl ether (EVE) and DMSO $(22 \mu \mathrm{L})$ was added to the mixture. The resultant mixture was stirred for $12 \mathrm{~h}$; then filtered and washed with DCM ( $3 \times 5 \mathrm{~mL})$. The volatiles were then removed. The crude was then dissolved in a minimal amount of DCM, and loaded t onto a silica plug. The mixture was eluted with EtOAc:hexanes. 
j. Olefin Hydrogenation (macrocycles $14 c, f, h, i, j$ and $\mathbf{1 5 b}$ )

Pd 5\%/alumina ( $11 \mathrm{mg}$ ) was weighed in a $5 \mathrm{~mL}$ round-bottom flask under nitrogen. 26 $\mu \mathrm{mol}$ of macrocycle were dissolved in $1 \mathrm{~mL}$ of EtOAc inside a vial. The latter solution was transferred to the Pd catalyst. The mixture was then shaken under hydrogen $(1 \mathrm{~atm})$ for $24 \mathrm{~h}$. The mixture was filtered through a small pad of Celite, and the volatiles removed in vacuo.

\section{k. Bts protection removal}

Please refer article experimental section.

l. Final Deprotection (macrocycles containing (D)Tyr)

Please refer article experimental section.

m. Purification

Please refer article experimental section. 


\section{Synthesis of tether components of macrocycles}

Please refer to Section 6 for copies of spectra and chromatograms.

a. Synthesis of tether alcohol 4 a (component of macrocycles $\mathbf{1}, \mathbf{1 2 a}-\mathbf{t}, \mathbf{1 3 b}$ )

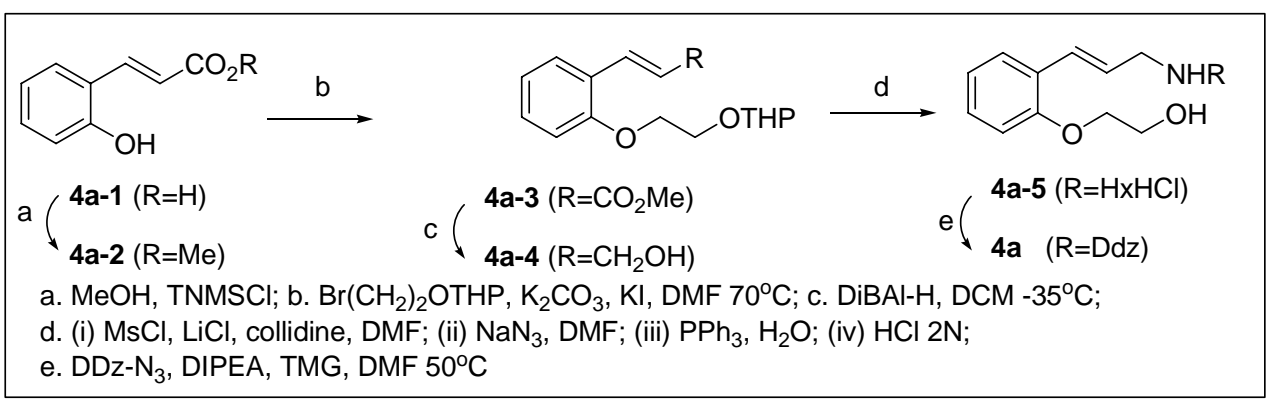

Step a. Chlorotrimethylsilane ( $116 \mathrm{~mL}, 0.91 \mathrm{~mol}, 1.5 \mathrm{eq})$ was added to a suspension of 2hydroxycinnamic acid 4a-1 (100 g, $0.61 \mathrm{~mol}, 1.0 \mathrm{eq})$ in methanol (500 mL, HPLC grade) over $30 \mathrm{~min}$ at $0^{\circ} \mathrm{C}$. The resulting mixture was stirred at room temperature overnight. After completion, the reaction mixture was evaporated to afford methyl 2hydroxycinnamate 2 as a white solid (108.5 g) in quantitative yield.

Step b. 3,4-Dihydro-2H-pyran (DHP, $140 \mathrm{~mL}, 1.54 \mathrm{~mol}, 2.52 \mathrm{eq}$ ) was added dropwise to bromoethanol $(108 \mathrm{~mL}, 1.51 \mathrm{~mol}, 2.5 \mathrm{eq})$ in a $2 \mathrm{~L}$ three-neck flask with mechanical stirring at $0^{\circ} \mathrm{C}$ over 2 hours. The resulting mixture was stirred for additional 1 hour at room temperature. Methyl 2-hydroxycinnamate 4a-2 (108 g, 0.61 mol, $1.0 \mathrm{eq})$, potassium carbonate $(92.2 \mathrm{~g}, 0.67 \mathrm{~mol}, 1.1 \mathrm{eq})$, potassium iodide $(20 \mathrm{~g}, 0.12 \mathrm{~mol}, 0.2 \mathrm{eq})$ and DMF (300 mL, spectrometric grade) were added to the above flask. The reaction mixture was stirred at $70^{\circ} \mathrm{C}$ (external temperature) for 24 hour. After cooling down to room temperature, ether $(450 \mathrm{~mL})$ was added. The inorganic salts were removed by filtration and washed with ether $(3 \times 50 \mathrm{~mL})$. The filtrate was diluted with hexane $(400 \mathrm{~mL})$ and washed with water $(3$ X $500 \mathrm{~mL})$, dried over anhydrous magnesium sulfate, filtered and evaporated. The crude ester (desired product 3 and excess $\mathrm{Br}-\mathrm{C}_{2} \mathrm{H}_{4}-\mathrm{OTHP}$ ) was used for subsequent reduction without any purification.

Step c. DIBAL (1.525 L, $1.525 \mathrm{~mol}, 2.5 \mathrm{eq}, 1.0 \mathrm{M}$ in DCM) was added slowly to a solution of crude ester 4a-3 (0.61 mol based on the theoretical yield) in anhydrous DCM $(610 \mathrm{~mL})$ at $-35^{\circ} \mathrm{C}$ with mechanical stirring over 1.5 hours. The resulting mixture was stirred for 1.5 hours at $-35^{\circ} \mathrm{C}$, then 1.5 hours at $0^{\circ} \mathrm{C} . \mathrm{Na}_{2} \mathrm{SO}_{4} \bullet 10 \mathrm{H}_{2} \mathrm{O}(100 \mathrm{~g}, 0.5 \mathrm{eq})$

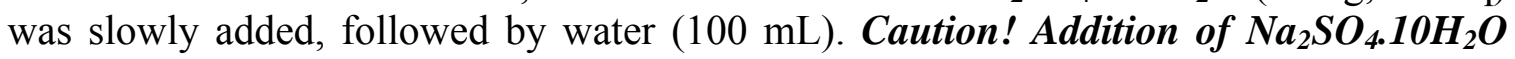
and water should be done very slowly, since extensive bubbling occurs during both steps. Adequate protection should be used. Since the mixture becomes thicker as reaction progresses, more DCM may be added to ensure efficient stirring. The mixture was then allowed to warm up to room temperature and stirred for 10 minutes, after which it was filtered. After washing the filter cake with DCM, the solid was extracted o/n using a Soxhlet apparatus. The original filtrate was evaporated to give a first fraction of the product, and the soxhlet extraction solvent was evaporated to obtain a second fraction. 
Both fractions were combined and purified on a dry-pack column (EtOAc/Hexane/triethylamine: 20/80/0.5) to give pure alcohol $\mathbf{4 a - 4}$ as a yellowish oil (yield: $90 \%$ ).

Step d. To a mixture of allylic alcohol 4a-4 (28 g, $0.100 \mathrm{~mol}, 1.0 \mathrm{eq})$ and collidine $(0.115$ mol, $1.15 \mathrm{eq}$ ) in $200 \mathrm{~mL}$ of anhydrous DMF under $\mathrm{N}_{2}$, was added anhydrous $\mathrm{LiCl}$ (4.69 $\mathrm{g}, 0.110 \mathrm{~mol}, 1.1$ eq.) dissolved in $100 \mathrm{~mL}$ of anhydrous DMF. The mixture was then cooled to $0^{\circ} \mathrm{C}$, and $\mathrm{MsCl}$ (13.3 g, $0.115 \mathrm{~mol}, 1.15$ eq., freshly distilled), was added dropwise. Reaction was allowed to heat up to room temperature, and a thick precipitate appeared. When the reaction was complete, $\mathrm{NaN}_{3}(32.7 \mathrm{~g}, 0.500 \mathrm{~mol}, 5.0 \mathrm{eq}$.) was added. The reaction mixture was stirred at room temperature $\mathrm{o} / \mathrm{n}$, then followed by NMR. When the reaction was complete, the mixture was poured on an ice-cooled water bath $(400 \mathrm{~mL})$, and extracted with $3 \times 300 \mathrm{~mL}$ ether:hexanes (1:1). The combined organic phases were then washed twice with $200 \mathrm{~mL}$ citrate buffer, twice with $200 \mathrm{~mL}$ saturated sodium bicarbonate $\mathrm{NaHCO}_{3}$, and finally with $200 \mathrm{~mL}$ brine. The organic layer was dried on magnesium sulfate and concentrated under vacuum. The allylic azide was obtained pure in $90 \%$ combined yield, and used as such for the following step.

$\mathrm{PPh}_{3}(25.9 \mathrm{~g}, 0.099 \mathrm{~mol}, 1.5 \mathrm{eq})$ was added in portions at $0^{\circ} \mathrm{C}$ to a solution of the allylic azide $(20.0 \mathrm{~g}, 0.066 \mathrm{~mol}, 1.0 \mathrm{eq}$.) dissolved in $100 \mathrm{~mL}$ of THF. The solution was stirred for 30 minutes at $0^{\circ} \mathrm{C}$ and 6-12 hours at room temperature. Water $(12 \mathrm{~mL})$ was added and the resulting solution was heated at $60^{\circ} \mathrm{C}$ for 4 hours. The solution was then cooled down to room temperature, $2 \mathrm{~N} \mathrm{HCl}(165 \mathrm{~mL}, 5$ eq.) was added and the mixture was stirred for $3 \mathrm{~h}$ at $\mathrm{rt}$. THF was removed in vacuo, then the remaining aqueous phase was extracted twice with $200 \mathrm{~mL}$ toluene, twice with $200 \mathrm{~mL}$ EtOAc, twice with toluene again and twice with EtOAc. The aqueous phase was cooled down to $0^{\circ} \mathrm{C}$, then a $5 \mathrm{~N}$ $\mathrm{NaOH}$ solution was added dropwise, until $\mathrm{pH}$ reached 12. It was extracted with $6 \times 200 \mathrm{~mL}$ EtOAc. The organic layers were dried on $\mathrm{MgSO}_{4}$, then the solvent was removed to yield an off-white solid. The latter was azeotroped three times with toluene. The crude product 4a-5 was used for the next reaction without further purification. Yield: $85-95 \%$.

Step e. A mixture of the crude aminoalocohol 4a-5 (0.28 mol., 73g), Ddz- $\mathrm{N}_{3}(83 \mathrm{~g}, 0.31$ mol, 1.1 eq) N,N,N',N'-tetramethylguanidine ( $43 \mathrm{~mL}, 0.34 \mathrm{~mol}, 1.2 \mathrm{eq}$ ) and DIPEA (60 $\mathrm{mL}, 0.34 \mathrm{mmol}, 1.2$ eq.) in degassed drisolv DMF $(180 \mathrm{~mL})$ was stirred for 24 hours at $50^{\circ} \mathrm{C}$. After the reaction was complete, the reaction mixture was poured in water $(400$ $\mathrm{mL})$. The aqueous phase was extracted with ether $(4 \mathrm{X} 200 \mathrm{~mL})$. The combined organic phases were washed with water ( 3 X $500 \mathrm{~mL}$ ) and brine (1 X $500 \mathrm{~mL})$, dried over $\mathrm{MgSO}_{4}$ and concentrated. The crude was purified by a dry-pack column (recommended column conditions: EtOAc/Hexane/triethylamine: $35 / 65 / 0.5$ to $65 / 35 / 0.5$ ) to give 4 a as a pale yellow syrup (yield: 102g, 87\%).

${ }^{1} \mathrm{H}$ NMR (300 MHz, DMSO-d 6 ) $\delta$ ppm 7.35-7.42 (m, 1H); $7.19(\mathrm{t}, 1 \mathrm{H}) ; 6.95(\mathrm{~d}, 1 \mathrm{H})$; $6.87(\mathrm{t}, 1 \mathrm{H}) ; 6.75(\mathrm{~d}, 1 \mathrm{H}) ; 6.43(\mathrm{~d}, 2 \mathrm{~h}) ; 6.35(\mathrm{~d}, 1 \mathrm{H}) ; 6.18(\mathrm{dt}, 1 \mathrm{H}) ; 4.82(\mathrm{t}, 1 \mathrm{H}) ; 3.97(\mathrm{t}$, $2 \mathrm{H}) ; 3.80-3.60$ (m, 10H); $1.62(\mathrm{~s}, 6 \mathrm{H})$.

${ }^{13} \mathrm{C}$ NMR (75.5 MHz, DMSO-d 6 ) $\delta$ ppm $160.8 ; 156.2 ; 155.4 ; 150.3 ; 129.2 ; 128.2 ; 127.0$; $125.9 ; 125.4 ; 121.2 ; 113.1 ; 103.4 ; 98.4 ; 80.1 ; 70.6 ; 60.4 ; 55.8 ; 43.2 ; 29.8$. LC-MS (Grad A4, CI) 7.56 min., 438 (M+23); 179 (carbinol cation). 
b. Synthesis of Ddz-4b (tether component of macrocycles 14m, 16a-i, 17a-g

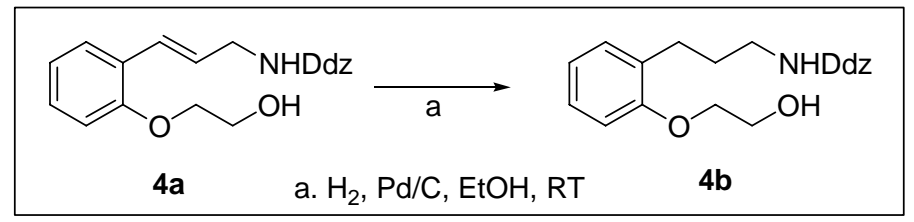

Step a. Tether $\mathbf{4 b}$ was obtained by hydrogenation of Ddz-tether $4 \mathbf{a}$ over $\mathrm{Pd} / \mathrm{C} \%$ in EtOH, at atmospheric pressure.

${ }^{1} \mathrm{H}$ NMR (300 MHz, $\left.\mathrm{CDCl}_{3}\right) \delta$ ppm 7.19-7.01, (m, 2H), 6.92-9.83 (m, 2H), 6.53 (bs, $2 \mathrm{H}), 6.34(\mathrm{t}, 1 \mathrm{H}), 5.17(\mathrm{bt}, 1 \mathrm{H}), 4.08(\mathrm{~m}, 2 \mathrm{H}), 3.98(\mathrm{~m}, 2 \mathrm{H}), 3.79(\mathrm{~s}, 6 \mathrm{H}), 3.01(\mathrm{bq}, 2 \mathrm{H})$, $2.66(\mathrm{t}, 3 \mathrm{H}), 1.26(\mathrm{bs}, 8 \mathrm{H})$;

${ }^{13} \mathrm{C} \mathrm{NMR}\left(\mathrm{CDCl}_{3}\right) \delta \mathrm{ppm} 160.9,156.8,155.6,149.6,130.4,127.5,121.2,111.7,103.2$, 98.4, 80., 69.7, 61.6, 55.5, 40.3, 30.5, 29.3, $27.4 \mathrm{ppm}$.

LC-MS (Grad A4) 7.90 min. 440 (M+23); 179 (Ddz cation); 196 (Ddz carbinol).

c. Synthesis of tethers $4 c \& 4 d$ (component of macrocycle $14 \mathbf{k} \& 14 d$, resp.)

$d$.

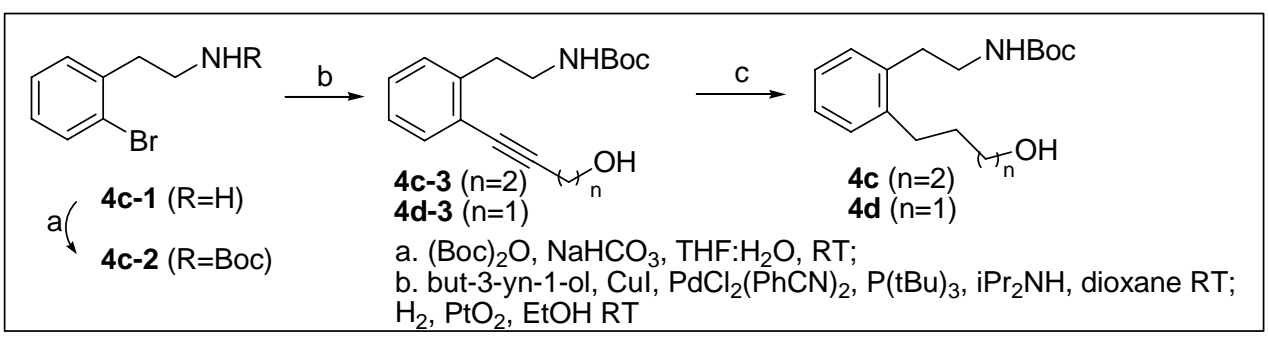

Step a. To a solution of 2-bromophenethylamine 4c-1 (5.0g, $25.0 \mathrm{mmol}, 1.0$ eq.) in 125 $\mathrm{mL} \mathrm{THF} / \mathrm{H}_{2} \mathrm{O}$ (1:1) mixture was added sodium bicarbonate (2.3g, $27.5 \mathrm{mmol}, 1.1$ eq.). The mixture was then cooled to $0^{\circ} \mathrm{C}$ and $\mathrm{Boc}$ anhydride $(5.5 \mathrm{~g} 25.0 \mathrm{mmol}, 1.0$ eq.) was added in one portion. The mixture was stirred at $0^{\circ} \mathrm{C}$ during 1 hour and allowed to warm up to room temperature and stirred overnight. The solvent was evaporated under reduced pressure and the residue was taken in $\mathrm{AcOEt} / \mathrm{H}_{2} \mathrm{O}$ (1:1) mixture. The separated organic phase was washed twice with $\mathrm{H}_{2} \mathrm{O}$, twice with saturated sodium chloride, dried over magnesium sulfate, filtered and evaporated under reduced pressure. The resulting yellow oil was diluted in DCM and evaporated 3 times under reduced pressure to give $7.5 \mathrm{~g}$ of 4c-2 as a white solid in quantitative yield.

Step b. To a flame dried flask under argon atmosphere was added 4c-2 $(6.3 \mathrm{~g}, 21.0 \mathrm{mmol}$, 1.0 eq.), recrystallized copper (I) iodide $(80.0 \mathrm{mg}, 0.42 \mathrm{mmol}, 0.02$ eq.) and dichlorobis(benzonitrile) palladium (II) $(242 \mathrm{mg}, 0.63 \mathrm{mmol}, 0.03 \mathrm{eq}$.). The flask was purged with argon (5-10 minutes) and $20 \mathrm{~mL}$ of anhydrous 1,4-Dioxane were added followed by tri-tert-butylphosphine $10 \%(\mathrm{w} / \mathrm{w})$ solution in Hexane $(385 \mathrm{uL}, 1.26 \mathrm{mmol}$, 0.06 eq.) and diisopropylamine $(3.6 \mathrm{~mL}, 25.2 \mathrm{mmol}, 1.2$ eq.). The mixture was then purged again with argon (5-10 minutes) and 3-butynol ( $2.4 \mathrm{~mL}, 31.5 \mathrm{mmol}, 1.5$ eq.) was added dropwise to the mixture and stirred 24 hours at room temperature under argon. The mixture was diluted with AcOEt, filtered on a silica gel pad and washed with AcOEt 
until there was no material coming out. The solvent was evaporated under reduced pressure and the crude was purified by flash chromatography to give $5.5 \mathrm{~g}$ of $4 \mathrm{c}-3 \mathrm{as}$ a pale-yellow oil in $90 \%$ yield.

Step c. To a solution of Boc-amino alcohol 4c-3 (6.1 g, $21.1 \mathrm{mmol}, 1.0$ eq.) in EtOH 95\% under nitrogen was added platinum (IV) oxide (445 mg, $2.11 \mathrm{mmol}, 0.1$ eq.). The mixture was then stirred 16 hours at $80 \mathrm{psi} \mathrm{H}_{2}$. When the reaction was complete, nitrogen was bubbled for 10 minutes to remove excess of hydrogen. The solvent was evaporated under reduced pressure, diluted with EtOAc, filtered on a silica gel pad and washed with EtOAc until there was no material coming out. The solvent was evaporated under reduced pressure and the crude purified by flash chromatography to give $4.5 \mathrm{~g}$ of $4 \mathrm{c}$ as pale yellow oil in $75 \%$ yield.

${ }^{1} \mathrm{H}$ NMR $\left(300 \mathrm{MHz}, \mathrm{CDCl}_{3}\right) \delta \mathrm{ppm} 7.18-7.11,(\mathrm{~m}, 4 \mathrm{H}), 4.65,(\mathrm{bs}, 1 \mathrm{H}), 3.72-3.65,(\mathrm{t}, 2 \mathrm{H})$, $3.32(\mathrm{bs}, 2 \mathrm{H}), 2.85-2.80,(\mathrm{t}, 2 \mathrm{H}), 2.70-2.65,(\mathrm{t}, 2 \mathrm{H}), 1.71-1.66(\mathrm{~m}, 4 \mathrm{H}), 1.44(\mathrm{~s}, 9 \mathrm{H})$.

LC-MS (Grad A4, CI) 7.24 min.; 316 (M+23); 194 (M-Boc).

e. Synthesis of tether Boc-4d (component of macrocycle 14b)

Step a. The same method as for tether Boc-4c was used, except that propargyl alcohol was used in the Sonogashira coupling.

${ }^{1} \mathrm{H} \mathrm{NMR}\left(\mathrm{CDCl}_{3}\right) \delta$ 7.20-7.12, (m, 4H), 4.73, (bs, 1H), 3.73-3.69, (t, 2H), 3.35-3.28 (bq, $2 \mathrm{H}), 2.87-2.77,(\mathrm{q}, 2 \mathrm{H}), 1.91-1.82(\mathrm{dt}, 4 \mathrm{H}), 1.46$ (s, 9H).

\section{f. Synthesis of tether 4 e (component of macrocycle 14e-h)}

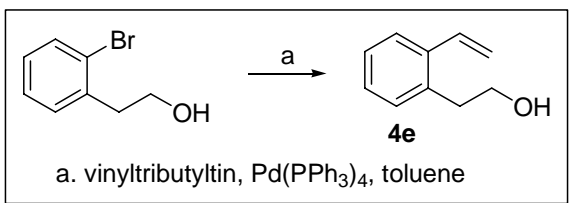

Step a. To a solution of bromophenethole $(2.0 \mathrm{~mL}, 14.9 \mathrm{mmol}, 1.0$ eq. $)$ in toluene (50 $\mathrm{mL})$ were added tetrakistriphenylphosphine palladium(0) $(347 \mathrm{mg}, 0.30 \mathrm{mmol}, 0.02$ eq.) and vinyltributyltin $(6.5 \mathrm{~mL}, 22.4 \mathrm{mmol}, 1.5 \mathrm{eq}$.). The resulting mixture was stirred at reflux for $24 \mathrm{hr}$ under $\mathrm{N}_{2}$. The reaction mixture was cooled down to room temperature and a saturated KF solution was added. The aqueous phase was extracted with DCM (4X) and the organic phase was extracted with brine. The organic phase was dried over $\mathrm{MgSO}_{4}$ and concentrated. The compound was purified by flash (30\% AcOEt, $70 \%$ hexane) to give a colorless oil. Purity was assessed by ${ }^{1} \mathrm{H}$ NMR (yield : 100\%).

${ }^{1} \mathrm{HNMR}\left(300 \mathrm{MHz}, \mathrm{CDCl}_{3}\right) \delta \mathrm{ppm}$ 7.57-7.45 (1H, m, Ph), 7.30-7.15 (3H, m, Ph), 7.05 $\left(\mathrm{dd}, 1 \mathrm{H}, \mathrm{PhC} \underline{\mathrm{H}}=\mathrm{CH}_{2}\right), 5.65(1 \mathrm{H}, \mathrm{dd}, \mathrm{PhCH}=\mathrm{C} \underline{H} \mathrm{H}), 5.32(1 \mathrm{H} . \mathrm{dd}, \mathrm{PhCH}=\mathrm{CH} \underline{\mathrm{H}}), 4.85(2 \mathrm{H}$, t, $\left.\mathrm{PhCH}_{2} \underline{\mathrm{C}}_{2} \mathrm{OH}\right), 2.98\left(2 \mathrm{H}, \mathrm{t}, \mathrm{PhC}_{2} \mathrm{CH}_{2} \mathrm{OH}\right), 1.50$ (1H, s, O프). 
g. Synthesis of tether 4 (component of macrocycle 14a-c)

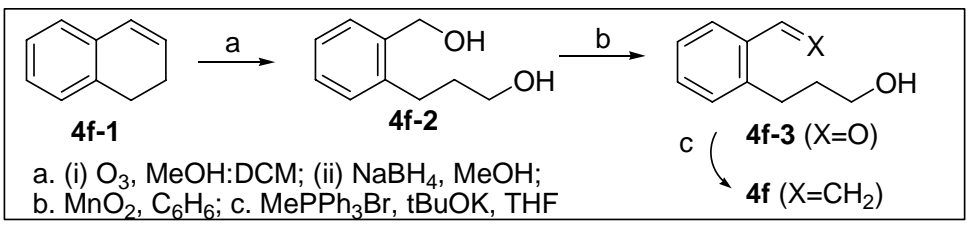

Step a. 1,2-dihydronaphtalene (5.0 g, $38.4 \mathrm{mmol}, 1.0$ eq. $)$ was dissolved in $200 \mathrm{~mL}$ of DCM : $\mathrm{MeOH}(1: 1)$ and the solution was cooled to $-78^{\circ} \mathrm{C} \cdot \mathrm{O}_{3}$ was bubbled through the solution until a blue color developed. Excess of $\mathrm{O}_{3}$ was then removed by bubbling $\mathrm{N}_{2}$ through the solution until the blue color had dissipated. Sodium borohydride ( $2.9 \mathrm{~g}, 76.8 \mathrm{mmol}, 2.0$ eq.) was added slowly and the mixture was stirred at room temperature $1 \mathrm{hr}$. A saturated ammonium chloride solution was added slowly and the aqueous phase was extracted with DCM (3X). The organic phase was dried over $\mathrm{MgSO}_{4}$, filtered and concentrated. Diol $\mathbf{4 f - 2}$ was obtained as a yellow oil (yield $=100 \%$ ).

Step b. To a solution of diol $\mathbf{4 f - 2}(6.38 \mathrm{~g}, 38.4 \mathrm{mmol}, 1.0$ eq.) in benzene (200 $\mathrm{mL}$ ) was added $\mathrm{MnO}_{2} 85 \%$ (16.7 g, $192 \mathrm{mmol}, 5.0$ eq.) and the mixture was stirred $1 \mathrm{hr}$. The reaction was checked by TLC and $\mathrm{MnO}_{2}$ (5 eq.) was added at each hour until the reaction was finished. The $\mathrm{MnO}_{2}$ was filtrated on celite and the celite was washed with AcOEt. The organic phase was concentrated and the crude 4f-3 used as such for the next step.

Step c. To a suspension of the $\mathrm{MePPh}_{3} \mathrm{Br}(30.2 \mathrm{~g}, 84.5 \mathrm{mmol}, 2.2$ eq.) in THF $(200 \mathrm{~mL})$ was added t-BuOK by portion $(9.5 \mathrm{~g}, 84.5 \mathrm{mmol}, 2.2 \mathrm{eq}$.$) and the resulting$ mixture was stirred at room temperature $2 \mathrm{hr}^{7}$. The reaction mixture was cooled to $78^{\circ}$ and the aldehyde $\mathbf{4 f - 3}$ (6.3 g, $38.4 \mathrm{mmol}, 1.0 \mathrm{eq}$. (based on the theorical yield)) was added over $10 \mathrm{~min}$. The mixture was stirred overnight at room temperature ${ }^{8}$. An ammonium chloride solution saturated was added and the aqueous phase was extracted with AcOEt (3X). The organic phase was dried over $\mathrm{MgSO}_{4}$, filtrated and concentrated. The compound was purified by flash (40\% AcOEt, $60 \%$ hexane) to give a yellow oil. NMR is taken to verify the compound (yield : 73\%, 2 steps).

${ }^{1} \mathrm{H}$ NMR $\left(300 \mathrm{MHz}, \mathrm{CDCl}_{3}\right) \delta \mathrm{ppm} 7.55-7.45(1 \mathrm{H}, \mathrm{m}, \mathrm{Ph}), 7.25-7.10(3 \mathrm{H}, \mathrm{m}, \mathrm{Ph})$, $7.05\left(\mathrm{dd}, 1 \mathrm{H}, \mathrm{PhC} \underline{\mathrm{H}}=\mathrm{CH}_{2}\right), 5.65(1 \mathrm{H}, \mathrm{dd}, \mathrm{PhCH}=\mathrm{C} \underline{\mathrm{H}}), 5.30(1 \mathrm{H} . \mathrm{dd}, \mathrm{PhCH}=\mathrm{CH} \underline{\mathrm{H}})$, $3.70\left(2 \mathrm{H}, \mathrm{t}, \mathrm{PhCH}_{2} \mathrm{CH}_{2} \mathrm{CH}_{2} \mathrm{OH}\right), 2.80\left(2 \mathrm{H}, \mathrm{t}, \mathrm{PhC}_{2} \mathrm{CH}_{2} \mathrm{CH}_{2} \mathrm{OH}\right), 1.90-1.80(2 \mathrm{H}, \mathrm{m}$, $\left.\mathrm{PhCH}_{2} \mathrm{CH}_{2} \mathrm{CH}_{2} \mathrm{OH}\right), 1.45$ (1H, s, O푸). 
h. Synthesis of tether $4 \mathrm{~g}$ (component of macrocycle 15a)

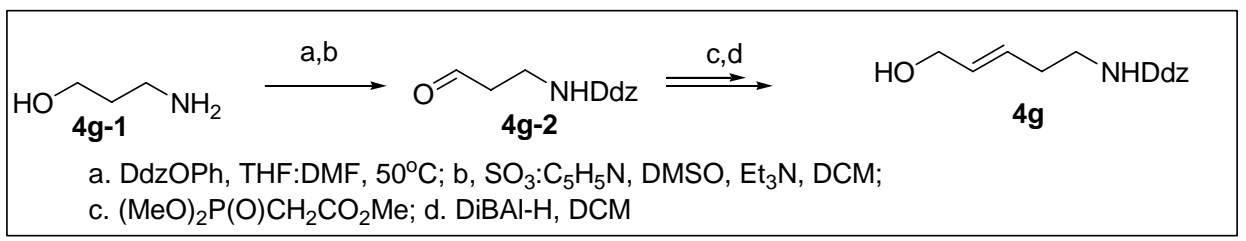

Step a. A solution of Ddz-OPh (100 g, 0.316 mol, 1.0 eq.) and 3-amino-1-propanol 4g-1 (2.0 eq.) in $1 / 1(\mathrm{v} / \mathrm{v}) \mathrm{DMF} / \mathrm{THF}(135 \mathrm{~mL})$ was stirred overnight at $50^{\circ} \mathrm{C}$. After removal of THF under reduced pressure, the residue was dissolved in ether $(400 \mathrm{ml})$ and washed with brine $(2 \times 100 \mathrm{ml})$. The brine phase was extracted with ether $(2 \times 100 \mathrm{~mL})$. The combined organic phase was washed with $1 \mathrm{~N} \mathrm{NaOH}$ solution saturated with $\mathrm{NaCl}(5 \mathrm{X}$ $100 \mathrm{ml})$, brine (1 X $100 \mathrm{ml}$ ), dried over magnesium sulfate, filtered and evaporated under reduced pressure to afford the crude 3-Ddz-amino-1-propanol. The alcohol was used as such in the following step.

Step b. Dimethyl sulfoxide (3 eq.) and triethylamine (3.5 eq.) were added to a solution of 3-Ddz-amino-1-propanol ( $84 \mathrm{~g}, 0.28 \mathrm{~mol}, 1 \mathrm{eq}$.) in dichloromethane $(250 \mathrm{~mL})$ at $0^{\circ} \mathrm{C}$. Sulfur trioxide pyridine complex (1.75 eq.) was then added in several portions. After the addition, the reaction mixture was stirred at $\mathrm{RT}$ and quenched by adding water $(150 \mathrm{~mL})$. Ether $(400 \mathrm{~mL})$ was then added to the reaction mixture. The separated aqueous phase was extracted with ether $(2 \mathrm{X} 100 \mathrm{~mL})$. The combined organic phase was washed with brine ( $3 \mathrm{X} 300 \mathrm{~mL}$ ), dried over magnesium sulfate, filtered and evaporated under reduced pressure to afford the crude 3 - Ddz-aminopropionaldehyde $\mathbf{4 g - 2}$ in quantitative yield.

Step c. To a solution of the crude aldehyde $\mathbf{4 g - 2}(0.28 \mathrm{~mol}, 1$ eq.) in acetonitrile $(500 \mathrm{~mL}$, HPLC grade), trimethyl phosphonoacetate (1.5 eq.) and anhydrous lithium hydroxide (1.5 eq.) were added at $0^{\circ} \mathrm{C}$ and then stirred overnight at room temperature. After removal of the volatiles by evaporation under reduced pressure, the residue was dissolved in ether $(400 \mathrm{~mL})$ and washed with water $(1 \mathrm{X} 100 \mathrm{~mL}), 1 \mathrm{~N}$ sodium hydroxide $(2 \mathrm{X} 100 \mathrm{~mL})$, brine (1 X $200 \mathrm{~mL})$, dried over magnesium sulfate, filtered and evaporated under reduced pressure. The crude was purified by a dry-pack column to afford the relatively pure trans- , -unsaturated ester (recommended column conditions:Hexanes/ ethyl acetate/ triethylamine: $75 / 25 / 0.5$ to $60 / 40 / 0.5, \sim 300 \mathrm{~g}$ of crude product can be separated by one dry-pack column ( $\sim 3 \mathrm{~L}$ silica gel).

Step d. Diisobutylaluminium hydride (1.0 $\mathrm{M}$ in dichloromethane, 3 eq.) was added dropwise to a solution of the ester $(0.24 \mathrm{~mol}, 1$ eq. $)$ in dry dichloromethane $(240 \mathrm{~mL}$, concentration: $1 \mathrm{M}$ ) at -30 to $-50^{\circ} \mathrm{C}$ (bath temp). The resulting mixture was stirred for additional 0.5-1 hour at the same temperature and warmed up to $0^{\circ} \mathrm{C}$ and stirred for another $0.5-1$ hour. Methanol ( $210 \mathrm{~mL}, 20 \mathrm{eq}$.) was added slowly, followed by ether (600 $\mathrm{mL}$ ), and water (43 $\mathrm{mL}, 10$ eq.) in $10 \mathrm{~min}$. After stirring for $20-30 \mathrm{~min}$, anhydrous magnesium sulfate $(\sim 20 \mathrm{~g})$ was added and stirred for several min. The mixture was filtered and the solid was continuously extracted with dichloromethane by Soxhlet extractor. The filtrate was evaporated under reduced pressure. The residue was purified 
by dry-pack column (recommended column condition: hexane/ethyl acetate/triethylamine: $60 / 40 / 0.5$ to $40 / 60 / 0.5, \mathrm{v} / \mathrm{v}$ ) to give the desired compound $\mathbf{4 g}$. The overall yield from Ddz-OPh is $45-53 \%$.

${ }^{1} \mathrm{H}$ NMR (300 MHz, DMSO-d 6 ) $\delta$ ppm 1.6 (s, 6H, 2 X CH3), 2.05 (m, 2H, CH2), 2.9 (m, $2 \mathrm{H}, \mathrm{CH} 2), 3.7$ (s, 6H, 2 X OCH3), 3.9 (m, 2H, CH2OH), $4.6(\mathrm{~m}, 1 \mathrm{H}, \mathrm{OH}), 5.5(\mathrm{~m}, 2 \mathrm{H}, 2$ $\mathrm{X} \mathrm{CH}), 6.3-6.5(\mathrm{~m}, 3 \mathrm{H}, 3 \mathrm{X} \mathrm{CH}), 7.1(\mathrm{~b}, 1 \mathrm{H}, \mathrm{NH})$.

${ }^{13} \mathrm{C}$ NMR $(75.5 \mathrm{MHz}$, DMSO-d 6 ) $\delta$ ppm $160.8 ; 155.3 ; 149.4 ; 132.0 ; 129.1 ; 103.3 ; 98.2$; $80.7 ; 63.6 ; 55.5 ; 40.1 ; 33.0 ; 29.3$.

LC-MS (Grad A4, CI) 6.45 min.; 357 (M+23); 179 (Ddz cation).

i. Synthesis of RCM tether $\mathbf{4 h}$ (component of macrocycle 14i)

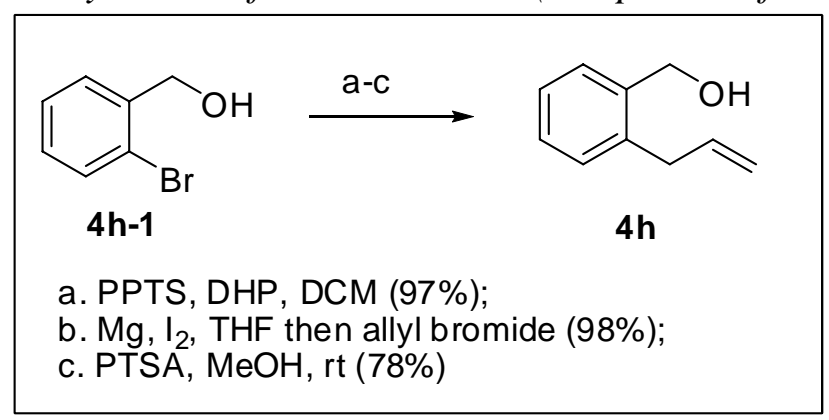

Tether $\mathbf{4 h}$ was synthesized using the procedure of Franz et al. ${ }^{1}$ with minor modifications.

j. Preparation of RCM tether $\mathbf{4 i}$ (component of macrocycle 17e)

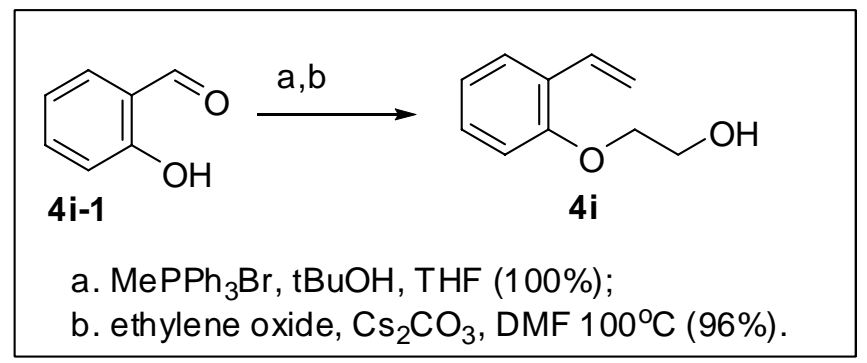

To a suspension of $\mathrm{MePPh}_{3} \mathrm{Br}(85.7 \mathrm{~g}, 240 \mathrm{mmol}, 2.2$ eq.) in THF $(500 \mathrm{~mL})$ was added tBuOK by portion $(26.9 \mathrm{~g}, 240 \mathrm{mmol}, 2.2 \mathrm{eq}$.) and the resulting mixture was stirred at room temperature $2 \mathrm{hr}$. The reaction mixture was cooled to $-78^{\circ} \mathrm{C}$ and salicylaldehyde (11.6 mL, $109 \mathrm{mmol}, 1.0 \mathrm{eq}$ ) was added over $10 \mathrm{~min}$. The mixture was stirred overnight at room temperature. A saturated ammonium chloride solution was added and the aqueous phase was extracted with ether (3X). The organic phase was dried over $\mathrm{MgSO}_{4}$, filtered and concentrated. The compound was purified by flash (30\% AcOEt, $70 \%$ hexane) to give a yellow oil. Identity and purity were assessed by ${ }^{1} \mathrm{H}$ NMR (yield : $100 \%)$.

To a solution of alcohol $\left(2.0 \mathrm{~g}, 16.7 \mathrm{mmol}, 1.0 \mathrm{eq}\right.$.) in DMF at $0^{\circ} \mathrm{C}$ was added cesium carbonate $(1.1 \mathrm{~g}, 3.34 \mathrm{mmol}, 0.2$ eq. $)$ ans the mixture was stirred at $0^{\circ} \mathrm{C}$ for $15 \mathrm{~min}$. The

\footnotetext{
${ }^{1}$ Franz, J. A.; Barrows, R. D.; Camaioni, D. M. J. Am. Chem. Soc. 1984, 106, 3964-3967.
} 
mixture was warmed at $100^{\circ} \mathrm{C}$ and ethylene carbonate was added. The resulting mixture was stirred at $100^{\circ} \mathrm{C}$ overnight. The solution was cooled to room temperature and water was added. The aqueous phase was extracted with ether (3X). The organic phase was extracted with brine (3X), dried with $\mathrm{MgSO}_{4}$, filtrated and concentrated. A yellow syrup was obtained (yield $=96 \%$ ). Purity was assessed by NMR.

${ }^{1} \mathrm{H}$ NMR $\left(300 \mathrm{MHz}, \mathrm{CDCl}_{3}\right) \delta(\mathrm{ppm}) 7.50(1 \mathrm{H}, \mathrm{dd}, \mathrm{Ph}), 7.22(1 \mathrm{H}, \mathrm{td}, \mathrm{Ph}), 7.05(\mathrm{dd}, 1 \mathrm{H}$, $\left.\mathrm{PhCH}=\mathrm{CH}_{2}\right), 6.98(1 \mathrm{H}, \mathrm{t}, \mathrm{Ph}), 7.90(1 \mathrm{H}, \mathrm{d}, \mathrm{Ph}), 5.75(1 \mathrm{H}, \mathrm{dd}, \mathrm{PhCH}=\mathrm{CH} H), 5.30(1 \mathrm{H}$. $\mathrm{dd}, \quad \mathrm{PhCH}=\mathrm{CH} \underline{\mathrm{H}}), \quad 4.15-4.10 \quad\left(2 \mathrm{H}, \quad \mathrm{m}, \quad \mathrm{PhOC}_{2} \mathrm{CH}_{2} \mathrm{OH}\right), \quad 4.05-3.95 \quad(2 \mathrm{H}, \quad \mathrm{m}$, $\left.\mathrm{PhOCH}_{2} \underline{\mathrm{C}}_{2} \mathrm{OH}\right), 2.05(1 \mathrm{H}, \mathrm{s}, \mathrm{OH})$.

k. Synthesis of RCM linker 7 (component of macrocycles $\mathbf{1 4 b}, \boldsymbol{c}, \boldsymbol{g}, \mathbf{h}, \mathbf{1 5 b}$ and 17e)

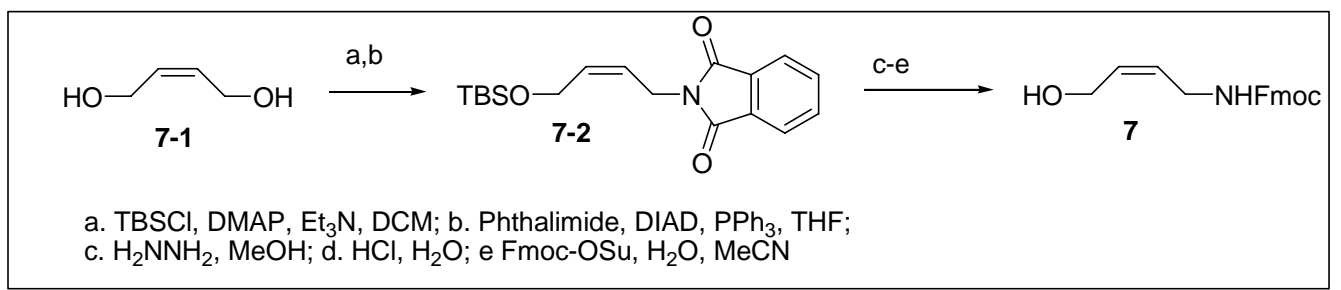

Step a. To a solution of diol 7-1 (50 g, $567 \mathrm{mmol}, 1.0 \mathrm{eq})$ in $\mathrm{CH}_{2} \mathrm{Cl}_{2}(1.5 \mathrm{~L})$ were added $\mathrm{Et}_{3} \mathrm{~N}(34.5 \mathrm{~mL}, 341 \mathrm{mmol}, 0.6 \mathrm{eq})$ and DMAP (1.73 g, $\left.14.2 \mathrm{mmol}, 0.025 \mathrm{eq}\right)$. TBDMSCl (42.8 g, $284 \mathrm{mmol}, 0.5 \mathrm{eq})$ in $\mathrm{CH}_{2} \mathrm{Cl}_{2}(100 \mathrm{~mL}$ ) was added over $4 \mathrm{~h}$ with a syringe pump at room temperature. The reaction mixture was stirred overnight, washed with water, aqueous $\mathrm{NH}_{4} \mathrm{Cl}$ and brine, and dried over $\mathrm{MgSO}_{4}$, filtered and evaporated. The residue was purified by flash (30\% AcOEt, $70 \%$ hexane) to give the alcohol the monoprotected diol (yield : 73\%).

Step $\boldsymbol{b}$. To a solution of the monoprotected diol $(18 \mathrm{~g}, 89 \mathrm{mmol}, 1.0 \mathrm{eq})$ in THF (180 mL) at $0^{\circ} \mathrm{C}$ were added $\mathrm{PPh}_{3}(30.4 \mathrm{~g}, 116 \mathrm{mmol}, 1.3 \mathrm{eq})$ and Phthalimide $(19.6 \mathrm{~g}, 134 \mathrm{mmole}$, $1.5 \mathrm{eq})$. Then DIAD $(22,8 \mathrm{~mL}, 116 \mathrm{mmole}, 1.3 \mathrm{eq})$ was added over $10 \mathrm{~min}$ at $0^{\circ} \mathrm{C}$. After one hour at $0^{\circ} \mathrm{C}$ the reaction was warmed up until room temperature and stirred overnight. The resulting mixture was concentrated and the residue was purified by flash chromatography (10\% AcOEt/Hexane) to give phthalimide 7-2 ( yield 95-100\%).

Steps c-e. To a solution of phthalimide 7-2 $(1.5 \mathrm{~g}, 4.7 \mathrm{mmole})$ in methanol $(87 \mathrm{~mL})$ at room temperature was added hydrazine $(17.4 \mathrm{mmole}, 558$ 1). The mixture was stirred $\mathrm{O} / \mathrm{N}$. The solution was concentrated under reduced pressure. Ethanol $(100 \mathrm{~mL})$ was added and the mixture was concentrated. This step was repeated twice. Methylene chloride $(80 \mathrm{~mL}$ ) was added to the residue then the solide was filtered (The solide was washed with with methylene chloride $(80 \mathrm{~mL})$ ), to give the amine as an oil (yield: $100 \%$ ). A solution of $\mathrm{HCl} 2 \mathrm{~N}(327 \mathrm{~mL}, 655 \mathrm{mmol}, 5.0$ eq) was added to the amine and the resulting mixture was stirred at room temperature for $2 \mathrm{~h}$. THF was evaporated and the aqueous phase was extracted with ether $(5 \mathrm{X} 150 \mathrm{~mL})$ and $\mathrm{CHCl}_{3}(3 \mathrm{X} 150 \mathrm{~mL})$.

The aqueous phase was neutralized to $\mathrm{pH}=8$ with $\mathrm{NaOH} 10 \mathrm{~N}$. $\mathrm{CH}_{3} \mathrm{CN}(400 \mathrm{~mL})$ was added to this aqueous solution and Fmoc-Suc $(41.9 \mathrm{~g}, 124 \mathrm{mmol}, 0.95 \mathrm{eq})$ in $\mathrm{CH}_{3} \mathrm{CN}$ 
(400 $\mathrm{mL})$ was added slowly $(50 \mathrm{~min})$. The solution was stirred at room temperature overnight ${ }^{5}$. The aqueous phase was extracted with ether and the combined organic phase was dried over $\mathrm{MgSO}_{4}$ and concentrated. The solid obtained was mixed with water (120 $\mathrm{mL}$ ), stirred $30 \mathrm{~min}$, filtered (to remove succinimide) and dried overnight on the pump. The solid was purified by flash chromatography $\left(50 \%\right.$ AcOEt, 50\% hexane ${ }^{8}$ to $70 \%$ AcOEt, 30\% hexane) to give compound 7 (C3 linker) as a white solid (yield : 68\% for 3 steps).

${ }^{1} \mathrm{H} \mathrm{NMR}\left(300 \mathrm{MHz}, \mathrm{CDCl}_{3}\right) \delta \mathrm{ppm} 7.8(\mathrm{~d}, 2 \mathrm{H}), 7.6(\mathrm{~d}, 2 \mathrm{H}), 7.4(\mathrm{t}, 2 \mathrm{H}), 7.3(\mathrm{t}, 2 \mathrm{H}), 5.9-$ $5.7(1 \mathrm{H}, \mathrm{m}), 5.6-5.5(1 \mathrm{H}, \mathrm{m}), 5.0(1 \mathrm{H}$, broad $), 4.4(2 \mathrm{H}, \mathrm{d}), 4.2(2 \mathrm{H}, \mathrm{d}), 3.9(2 \mathrm{H}$, broad), 2.1 (1H, broad).

${ }^{13} \mathrm{C} \mathrm{NMR}\left(75.5 \mathrm{MHz}, \mathrm{CDCl}_{3}\right) \delta \mathrm{ppm} 156.8,144.1,141.5,131.9,128.3,127.9,127.3$, 125.2, 120.2, 67.0, 58.0, 47.4, 38.0.

LC-MS (Grad A4, CI) 7.25 min.; $310(\mathrm{M}+1)$; 179 (fluorene cation).

\section{l. Preparation of RCM linker 8 (component of macrocycles 14a,e,f,i)}

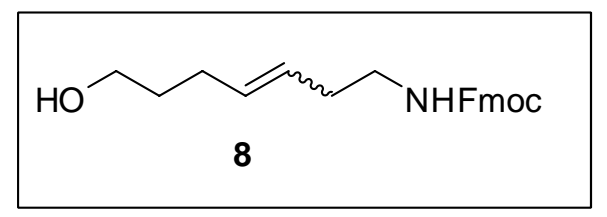

RCM linker 8 was prepared by selective cross-metathesis as described by Hoveyda and Vézina. $^{2}$

\footnotetext{
${ }^{2}$ Hoveyda, H. R.; Vézina, M. Org. Lett. 2005, 7, 2113-2116.
} 


\section{Details of Macrocycles syntheses}

\section{a) Synthesis of macrocycles 1, 12a-t, 14d, 14k-n, 15a, 16a-i, 17c,d}

These macrocycles were synthesized using method A as described.

\section{b) Synthesis of macrocycles 14a-c, 14e-i, 15b}

These macrocycles were synthesized using method B as described. Only macrocycles 14c,f,h,i and 15b underwent final hydrogenation of the unsaturation. Macrocycle 15b was synthesized using linker 7 and hex-6-en-1-ol as a tether.

\section{c) Synthesis of linear peptides 13a,b}

Linear peptides 13a,b were synthesized using method A up to Mitsunobu step (13b) or up to tripeptide stage (13a), except that a Rink amide resin was used. After cleavage, acetylation $\left(\mathrm{Ac}_{2} \mathrm{O}\right.$, DIPEA, DCM) gave the desired product, which was purified by RP-HPLC.

\section{d) Synthesis of macrocycles 17a,b}

Macrocycles 17a,b were synthesized with method A with the following modifications:

- instead of a Ddz- or Boc- amino acid, a THP-protected hydroxyacid was used.

- coupling reagent was DIC in THF for anchoring of the THP-protected hydroxyacid

- for THP deprotection, a solution of $25 \mathrm{mg}$ PTSA in $5 \mathrm{ml}$ of DCM:MeOH $(97: 3)$ was prepared, and the minikan shaken on this solution for $1 \mathrm{~h}$ twice. Washings were done as described.

- For ester bond formation, the protected amino acid was anchored using DIC ( 1 eq. wrt amino acid) and DMAP (0.05 eq. wrt amino acid), in NMP, the rest is as detailed in procedure $A$.

- For Bts removal, a 1:1 mixture of PS-thiophenoxide and PS-thiophenol resin was used, in DMF. The rest is as detailed in procedure A. 


\section{e) Synthesis of macrocycle 17e}

Macrocycle 17e was synthesized according to the scheme below.

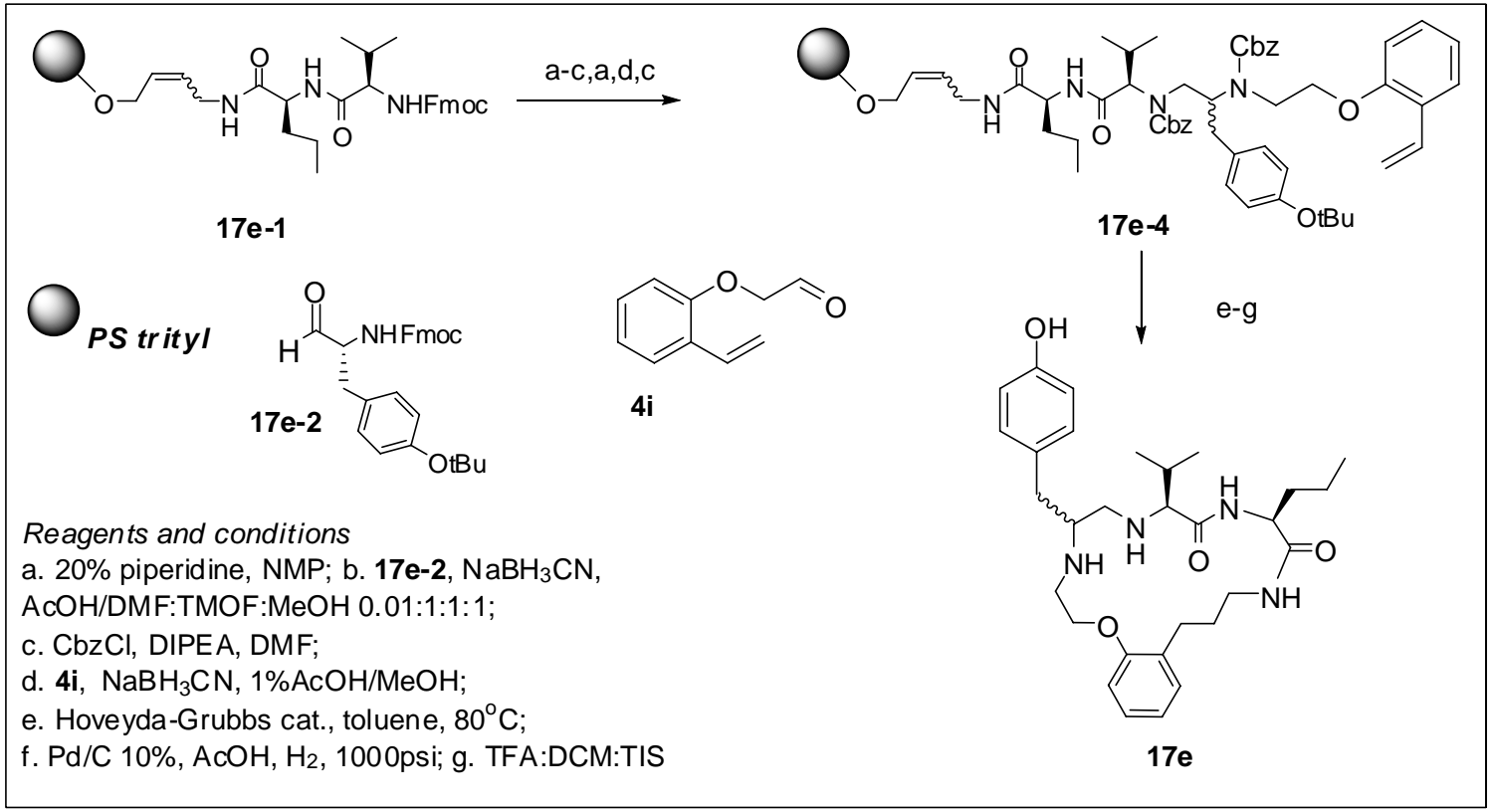

Essentially, synthesis of $\mathbf{1 7 e - 1}$ follows the procedure for method B. Compound 17e-2 was synthesized as describe din the literature. ${ }^{3}$

Steps $a, b$

The following stock solutions were prepared first.

Solution A: $100 \mathrm{~mL}$ of $1 \% \mathrm{AcOH}$ in TMOF.

Solution B: $100 \mathrm{~mL}$ of $1 \% \mathrm{AcOH}$ in $\mathrm{DMF} / \mathrm{TMOF} / \mathrm{MeOH}(1: 1: 1)$. After deprotection of Fmoc group in 17e-1 with $20 \%$ piperdine in DMF, $2.0 \mathrm{~g}(1.5 \mathrm{mmol})$ of resin were washed 6 times with solution A, dried and transferred into a $100 \mathrm{~mL}$ round bottom flask under $\mathrm{N}_{2}$ atmosphere. $4.6 \mathrm{~g}$ (10.5 mmol, $7.0 \mathrm{eq})$ of aldehyde 17e-2 were dissolved in $25 \mathrm{~mL}$ of solution $\mathrm{B}$ and added to the resin. The mixture was stirred at $50^{\circ} \mathrm{C}$ for 45 minutes. 1.0 gram (15.8 mmol, $10.5 \mathrm{eq})$ of $\mathrm{NaBH}_{3} \mathrm{CN}$ was dissolved in $10 \mathrm{~mL}$ of solution $\mathrm{B}$ and added to the above mixture. The contents were stirred for an additional 2.5 hours at $50^{\circ} \mathrm{C}$. The resin was then washed with DMF (5x), alternate cycles of DCM/MeOH (2x), DCM (5x) and dried in vacuo. $10 \mathrm{mg}$ of resin was cleaved and the ELSD result showed $86 \%$ of desired product with $8 \%$ of starting material.

Step c

To the above resin $(1.5 \mathrm{mmol})$ was added $50 \mathrm{~mL}$ of DMF (drisolv), followed by $4.0 \mathrm{~mL}$ (23mmol, $15 \mathrm{eq})$ of DIPEA and $2.1 \mathrm{~mL}(15 \mathrm{mmol}, 10 \mathrm{eq})$ of $\mathrm{CbzCl}$. The mixture was shaken on an orbital shaker overnight. The resin was then washed with DMF $(5 \mathrm{x})$, $\mathrm{DCM} / \mathrm{MeOH}$ alternate cycles $(4 \mathrm{x}), \mathrm{DCM}(5 \mathrm{x})$ and dried. $10 \mathrm{mg}$ of resin was cleaved and the ELSD showed the desired product.

\footnotetext{
${ }^{3}$ Fehrentz et al. Synthesis 1983, 676; Wen et al. Tetrahedron : Asymmetry 1998, 9, 1855
} 


\section{Steps $a, d$}

After cleavage of the Fmoc group in standard conditions (step b), $1.73 \mathrm{~g}(1.2 \mathrm{mmol})$ of resin was washed 5 times with $1 \% \mathrm{AcOH}$ in $\mathrm{MeOH}$. To this resin was added a solution made of $300 \mathrm{mg}(1.8 \mathrm{mmol}, 1.5 \mathrm{eq})$ of aldehyde $4 \mathbf{i}$ in $15 \mathrm{~mL}$ of MeOH (drisolv) and $5 \mathrm{~mL}$ of TMOF. This was followed by addition of $0.24 \mathrm{~mL}(2.4 \mathrm{mmol}, 2.0 \mathrm{eq})$ of borane:pyridine complex and the reaction was kept shaking on the orbital shaker for 24 hours. The resin was washed with the following solvent systems: $\mathrm{MeOH}(10 \mathrm{x})$, $\mathrm{DMF} / \mathrm{MeOH}$ alternate cycles $(5 \mathrm{x}), \mathrm{THF} / \mathrm{MeOH}$ alternate cycles $(3 \mathrm{x})$, THF $(2 \mathrm{x})$, $\mathrm{DCM} / \mathrm{MeOH}$ alternate cycles $(3 \mathrm{x}), \mathrm{CHCl}_{3}(2 \mathrm{x}), \mathrm{DCM}(4 \mathrm{x})$.

To 1.7 gram $(1.2 \mathrm{mmol})$ of the above resin was added $30 \mathrm{~mL}$ of DMF (drisolv) followed by $2.8 \mathrm{~mL}$ DIPEA (16 mmol, $13 \mathrm{eq})$ and $1.7 \mathrm{~mL}(12 \mathrm{mmol}, 10 \mathrm{eq})$ of $\mathrm{CbzCl}$. The mixture was shaken overnight. The resin was washed with DMF $(5 x), \mathrm{DCM} / \mathrm{MeOH}$ alternate cycles (3x) and DCM (5x) and dried at pump. $50 \mathrm{mg}$ of resin was cleaved for ELSD analysis. The analysis showed the desired product 17e-4 to be formed.

\section{Step e}

This step was carried out using Hoveyda-Grubbs second generation catalyst as indicated in procedure $\mathrm{B}$.

\section{Step $f$}

$94 \mathrm{mg}$ ( $0.11 \mathrm{mmols})$ of bis-Cbz macrocycle was dissolved in $15 \mathrm{~mL}$ of glacial $\mathrm{AcOH}$ in a $50 \mathrm{~mL}$ beaker and $188 \mathrm{mg}$ of $\mathrm{Pd}$ on $10 \% \mathrm{C}$ was added. After degassing, the solution was stirred under 1000psi of $\mathrm{H}_{2}$ for $7 \mathrm{~h}$. The reaction mixture was then filtered through celite and the celite was washed twice with $10 \mathrm{~mL}$ glacial $\mathrm{AcOH}$. The filtrate was then evaporated and the compound dried in vacuo. ELSD analysis showed the formation of the desired product.

\section{Step $g$}

This step was carried out following the procedure for method B. 


\section{f) Synthesis of macrocycle 17f}

The procedure of Vidal et $a .^{2}$ was used with modifications for the synthesis of building block 17f-6, as indicated below. Otherwise, method A was used for the synthesis of macrocycle 17f. At the end of the synthesis, the benzyl protection was removed by hydrogenolysis as indicated in the synthesis of macrocycle 17e (p. 15).

\section{Synthesis of N-Boc-3-(4-cyanophenyl)oxaziridine (17f-4) ${ }^{4}$}

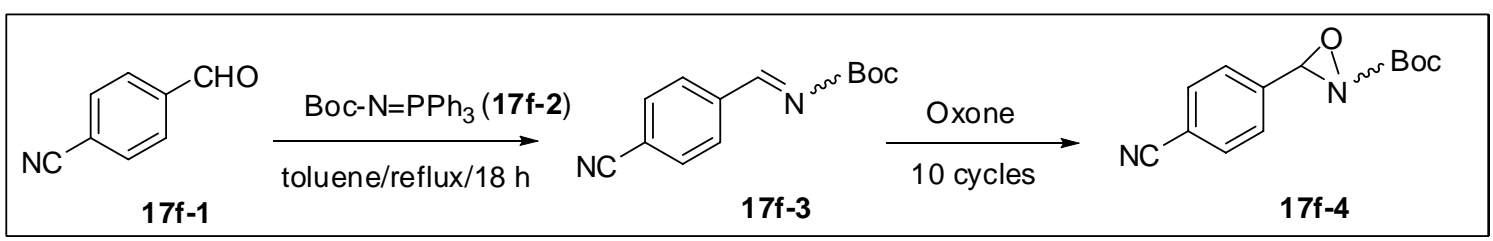

To a solution of iminophosphane (17f-2, $32 \mathrm{~g}, 85 \mathrm{mmol}, 1.05$ equiv) in toluene (dry, 50 $\mathrm{mL}$ ) was added 4-cyanobenzaldehyde $\left(7,10.6 \mathrm{~g}, 80.8 \mathrm{mmol}, 1.0\right.$ equiv) under $\mathrm{N}_{2}$. The mixture was heated to reflux (oil bath: $136^{\circ} \mathrm{C}$ ) for $18 \mathrm{~h}$. The oil bath was removed and the solution was allowed to be cooled to room temperature. Hexane (dry, $50 \mathrm{~mL}$ ) was added, triphenylphosphane oxide was precipitated and was removed by filtration. The white solid was eluted with hexane (dry, $30 \mathrm{~mL}$ ). The combined organic phase was concentrated by rotary evaporator ${ }^{5}$ and vacuum drying to give the residue which was used immediately for the next oxidation without further purification. ${ }^{6}$

To a solution of crude imine (17f-3, $13.1 \mathrm{~g})$ in $\mathrm{CHCl}_{3}{ }^{7}(200 \mathrm{~mL})$ was added a pre-cooled solution of $\mathrm{K}_{2} \mathrm{CO}_{3}(45 \mathrm{~g})$ in $\mathrm{H}_{2} \mathrm{O}(350 \mathrm{~mL})$. The solution was vigorously stirred by mechanical stirrer and cooled to $0-4{ }^{\circ} \mathrm{C}$ with external ice- $\mathrm{H}_{2} \mathrm{O}$ bath. A pre-cooled solution of $\mathrm{Oxone}^{8}(70 \mathrm{~g})$ in $\mathrm{H}_{2} \mathrm{O}(700 \mathrm{~mL})$ was added in $10 \mathrm{~min}$. The mixture was stirred at $0-4{ }^{\circ} \mathrm{C}$ for $50 \mathrm{~min}$. The aqueous phase was discarded, and the fresh solutions

of $\mathrm{K}_{2} \mathrm{CO}_{3}$ and Oxone were added as same as above. Total 10 cycles were needed. ${ }^{9}$ The layers were separated. Organic phase was washed with $\mathrm{H}_{2} \mathrm{O}(2 \times 100 \mathrm{~mL})$, dried over anhydrous $\mathrm{Na}_{2} \mathrm{SO}_{4}$. The solution was concentrated by rotary evaporator and vacuum drying to give the crude product which was purified by column chromatography of silicagel (hexane/ether 10/1,5/1,3/1) to afford $6.6 \mathrm{~g}$ (33\% based on 17f-1) of $\mathbf{1 7 f - 4}$ as a white solid. ${ }^{10}$

Data for 17f-4:

$\underline{\mathrm{HNMR}}\left(\mathrm{CDCl}_{3}, 300 \mathrm{MHz}\right)$ :

\footnotetext{
${ }^{4}$ (a) Vidal, J.; Guy, L.; Sterin, S.; Collet, A. J. Org. Chem. 1993, 58, 4791-4793. Vidal, J.; Damestoy, S.; Guy, L.; Hannachi, J.-C.; Aubry, A.; Collet, A. Chem. Eur. J. 1997, 3, 1691-1709.

${ }^{5}$ The vacuum was generated by vacuum line and not by water aspirator.

${ }^{6}$ The crude product was passed through a short column of silicagel quickly according to reference 8 . This will result in very low yield.

${ }^{7} \mathrm{CHCl}_{3}$ was passed through a pad of $\mathrm{K}_{2} \mathrm{CO}_{3}$ to remove traces of acid.

${ }^{8}$ Use of a freshly opened bottle of Oxone is recommended.

${ }^{9}$ The reaction was not completed under 6 cycles (reference 8). The un-oxidized imine 17f-3 was hydrolyzed to aldehyde 17f-1 during silicagel column chromatography purification. 17f-1 was extremely difficult to be separated from desired product oxiziridine $\mathbf{1 7 f}-\mathbf{4}$.

${ }^{10} 96 \%$ desired product, $4 \%$ 4-cyanobenzaldehyde from ${ }^{1} \mathrm{HNMR}$
} 
$7.72(\mathrm{~m}, 2 \mathrm{H}), 7.61(\mathrm{~m}, 2 \mathrm{H}), 5.35(\mathrm{~s}, 1 \times 0.11 \mathrm{H}$, cis isomer $), 5.07(\mathrm{~s}, 1 \times 0.89 \mathrm{H}$, trans isomer), $1.55(\mathrm{~s}, 9 \times 0.89 \mathrm{H}$, trans isomer), $1.16(\mathrm{~s}, 9 \times 0.11 \mathrm{H}$, cis isomer)

\section{Synthesis of Hydrazinopeptide 17f-6 Building Block ${ }^{11}$}

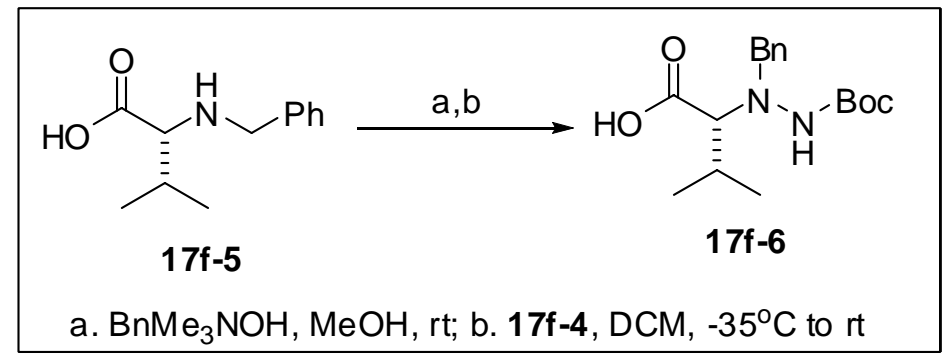

To a suspension of Bn-(D)-Val-OH 17f-5 (1.036 g, 5.0 mmol, 1.0 equiv) in MeOH (dry, $5.0 \mathrm{~mL})$ was added a solution of benzyltrimethylammonium hydroxide $(2.2 \mathrm{~g}, 40 \% \mathrm{wt}$ in $\mathrm{MeOH}, 1.05$ equiv) ${ }^{12}$ under $\mathrm{N}_{2}$. This suspension became a colorless homogenous solution, and was stirred at room temperature for $30 \mathrm{~min}$. The solvent was completely removed by vacuum line. ${ }^{13}$ DCM (dry, $5.0 \mathrm{~mL}$ ) was added under $\mathrm{N}_{2}$. The solution was cooled to $-35{ }^{\circ} \mathrm{C}$ (DCE-dry ice). A solution of oxaziridine $\mathbf{1 7 f}-4$ (1.85 g, $7.5 \mathrm{mmol}, 1.5$ equiv) in DCM (dry, $5.0 \mathrm{~mL}$ ) was then added dropwise by syringe. The solution was stirred at $-35{ }^{\circ} \mathrm{C}$ for $1.0 \mathrm{~h}$, was then allowed to warm to room temperature, and stirred at room temperature overnight $(\sim 16 \mathrm{~h})$. The solvent was removed by rotary evaporator and vacuum drying to give the residue. $\mathrm{H}_{2} \mathrm{O}(20 \mathrm{~mL})$ was added and stirred at room temperature for $10 \mathrm{~min}$. The yellow solid was removed by filtration, eluted with $\mathrm{H}_{2} \mathrm{O}(8.0$ $\mathrm{mL})$. The combined aqueous phase was extracted with ether $(2 \times 10 \mathrm{~mL})$. The basic aqueous solution was acidified with $\mathrm{KHSO}_{4}(\sim 800 \mathrm{mg})$ to $\mathrm{pH} 2-3$. The acidified aqueous solution was extracted with DCM $(3 \times 15 \mathrm{~mL})$. The DCM extracted solution was concentrated by rotary evaporator and vacuum drying to afford $1.40 \mathrm{~g}(87 \%)^{14}$ of $\mathbf{1 7 f - 6}$ as a white solid.

Data for 17f-6:

${ }^{1} \mathrm{HNMR}\left(\mathrm{CDCl}_{3}, 300 \mathrm{MHz}\right)$ :

$7.33(\mathrm{~m}, 5 \mathrm{H}), 3.97(\mathrm{~m}, 2 \mathrm{H}), 3.17(\mathrm{~s}, \mathrm{br}, 1 \mathrm{H}), 2.12(\mathrm{~m}, 1 \mathrm{H}), 1.38(\mathrm{~s}, 9 \mathrm{H}), 1.11$ $(\mathrm{d}, J=6.5,3 \mathrm{H}), 0.98(\mathrm{~d}, J=6.5,3 \mathrm{H})$

$\underline{\mathrm{MS}}$

$$
\mathrm{M}^{+}+\mathrm{H}^{+}-\text {Boc: } 223 \text { (ELSD 100\%; CLND 97\%) }
$$

\footnotetext{
${ }^{11}$ Guy, L.; Vidal, J.; Collet, A. J. Med. Chem. 1998, 41, 4833-4843.

${ }^{12}$ More solution needs to be added until homogenous solution formed

${ }^{13}$ residual $\mathrm{MeOH}$ will jeopadize the subsequent amination reaction.

${ }^{14}$ Yield for $2.0 \mathrm{mmol}$ scale reaction is $68 \%$ that is same as what reported in reference 16 .
} 


\section{g) Synthesis of macrocycle $17 \mathrm{~g}$}

Macrocycle 14m (5 mg) was stirred in the presence of aq. formaldehyde (20 eq.) and $\mathrm{NaBH}_{3} \mathrm{CN}$ (10 eq.) in MeCN overnight. $\mathrm{pH}$ was kept around 5.5 by addition of small amounts of acetic acid. Crude was poured in $\mathrm{NaOH} 0.1 \mathrm{M}$ and extracted with AcOEt four times. The combined organic fractions were dried on $\mathrm{MgSO} 4$ and the solvent was evaporated. Product was purified by RP-HPLC. 


\section{Characterization of Final Macrocycles}

Purity of all macrocycles was ascertained by LC-MS using the method described below. Selected macrocycles were run in chiral HPLC (UV detection) using two reverse-phase columns. A copy of chromatograms (UV, ELSD \& CLND detectors as well as MS) is provided in Section 8.

Identity of final compounds was confirmed by HRMS. Selected macrocycles were further characterized by ${ }^{1} \mathrm{H}$ and ${ }^{13} \mathrm{C}$ NMR, description of spectra is summarized in section $5 \mathrm{~b}$. A copy of ${ }^{1} \mathrm{H}$ and ${ }^{13} \mathrm{C}$ NMR spectra is provided in Section 8 .

Table 1 (section 5a) summarizes the results of HRMS, HPLC purities and chiral HPLC results. 


\section{a. Analytical methods}

Analyses were performed by LC/MS, using UV, ELSD and CLND detector and the following instruments:

MS:

HPLC:

UV detector:

ELSD detector:

CLND detector:

Column:
Micromass LC Platform

Waters HPLC 2695 Separation Module

Waters PDA 996

Polymer Lab ELSD PL-ELS-1000 detector

Antek CLND 8060 detector

XTerra MS C18 3.5 m 4.6X50 mm Column

Analytical method for final QC of building blocks (Grad A4)

5 minutes gradient from $5 \%$ to $65 \%$ methanol $/ 0.1 \%$ TFA in water

4 minutes at $65 \%$ methanol/ $0.1 \%$ TFA in water

5 minutes gradient from $65 \%$ to $90 \%$ methanol $/ 0.1 \%$ TFA in water

3 minutes at $90 \%$ methanol/ $0.1 \%$ TFA in water

0.5 minutes gradient from $90 \%$ to $5 \%$ methanol/0.1\% TFA in water

2.5 minutes at $5 \%$ methanol $/ 0.1 \%$ TFA in water

Flow: $1 \mathrm{ml} / \mathrm{min}$

Column Temperature: $35^{\circ} \mathrm{C}$

Samples Temperature: $20{ }^{\circ} \mathrm{C}$

QC of final macrocycles (Grad B4).

6 minutes gradient from 5\% to $50 \%$ methanol/0.1\% TFA in water

3 minutes at $50 \%$ methanol $/ 0.1 \%$ TFA in water

5 minutes gradient from $50 \%$ to $90 \%$ methanol $/ 0.1 \%$ TFA in water

3 minutes at $90 \%$ methanol $/ 0.1 \%$ TFA in water

0.5 minutes gradient from $90 \%$ to $5 \%$ methanol/ $0.1 \%$ TFA in water

2.5 minutes at $5 \%$ methanol $/ 0.1 \%$ TFA in water

Flow: $1 \mathrm{ml} / \mathrm{min}$

Column Temperature: $35^{\circ} \mathrm{C}$

Samples Temperature: $20{ }^{\circ} \mathrm{C}$ 


\section{b. LC/MS and HRMS data}

\section{Table 1: analytical results}

\begin{tabular}{|c|c|c|c|c|c|c|c|}
\hline \multirow{2}{*}{$\begin{array}{l}\text { Compound } \\
\text { Number }\end{array}$} & \multicolumn{3}{|c|}{ HRMS } & \multicolumn{3}{|c|}{ Purity (\%) } & \multirow{2}{*}{$\begin{array}{c}\text { RT } \\
\text { (min) }\end{array}$} \\
\hline & formula & calc. & found & UV & ELSD & CLND & \\
\hline 1 & $\mathrm{C} 30 \mathrm{H} 40 \mathrm{~N} 4 \mathrm{O} 5$ & 536.2998 & $536.2995 \pm 0.0016$ & 99.4 & 100 & 100 & 7.86 \\
\hline $12 a$ & $\mathrm{C} 24 \mathrm{H} 36 \mathrm{~N} 4 \mathrm{O} 4$ & 444.2736 & $444.2744 \pm 0.0013$ & 92.2 & 93.9 & 88 & 7.76 \\
\hline $12 b$ & $\mathrm{C} 30 \mathrm{H} 40 \mathrm{~N} 4 \mathrm{O} 5$ & 536.2998 & $536.2995 \pm 0.0016$ & 100 & 100 & 100 & 7.49 \\
\hline $12 \mathrm{c}$ & $\mathrm{C} 26 \mathrm{H} 40 \mathrm{~N} 4 \mathrm{O} 4$ & 472.3049 & $472.3038 \pm 0.0014$ & & & & \\
\hline $12 d$ & $\mathrm{C} 27 \mathrm{H} 43 \mathrm{~N} 5 \mathrm{O} 4$ & 501.3315 & $501.3309 \pm 0.0015$ & 91.7 & 92.4 & 86.5 & 7.06 \\
\hline $12 e$ & C28H34N4O5 & 506.2529 & $506.2538=$ & & & & \\
\hline $12 f$ & $\mathrm{C} 30 \mathrm{H} 40 \mathrm{~N} 4 \mathrm{O} 4$ & 520.3049 & 520.3057 & 96.0 & 100 & 93.4 & 9.31 \\
\hline $12 \mathrm{~g}$ & C28H36N4O5 & 508.2685 & $508.2681 \pm 0.0015$ & 100 & 100 & 96.8 & 7.65 \\
\hline $12 \mathrm{~h}$ & 5 & 0.2998 & 536.30 & 100 & 100 & 99.4 & 7.68 \\
\hline $12 \mathbf{i}$ & 55 & 530.2529 & 530.25 & 90.9 & 97.1 & 96.9 & 7.64 \\
\hline 12j & D6 & 524.2635 & 524.26 & 88.4 & 98.9 & 87.1 & 7.15 \\
\hline $12 \mathrm{k}$ & C34 & 584.2998 & $584.2974 \pm 0.0017$ & 98.1 & 100 & 100 & 9.71 \\
\hline $12 m$ & 1405 & 508.2685 & $508.2691 \pm 0.0015$ & 100 & 100 & 100 & 7.24 \\
\hline $12 n$ & 105 & 536.2998 & 536.29 & 88.7 & 85.6 & 94.0 & 8.17 \\
\hline $12 p$ & C28 & 524.2635 & 524.2626 & 98.9 & 100 & 100 & 5.88 \\
\hline $12 q$ & C31H43N5O5 & 565.3264 & $565.3260 \pm 0.0017$ & 98.9 & 100 & 100 & 5.66 \\
\hline $12 r$ & $29 \mathrm{H} 34 \mathrm{~N} 4 \mathrm{O} 6(\mathrm{M}-\mathrm{H} 2 \mathrm{O})$ & 534.2478 & $534.2468 \pm$ & 86.9 & 100 & 100 & 6.65 \\
\hline $12 \mathrm{~s}$ & $\mathrm{C} 34 \mathrm{H} 42 \mathrm{~N} 4 \mathrm{O} 5$ & 586.3155 & $586.3145 \pm 0.0017$ & 100 & 100 & 100.0 & 9.15 \\
\hline $12 t$ & 405 & $\mid 550.3155$ & 550.3150 & 99.3 & 100 & 100 & 8.64 \\
\hline $13 \mathbf{a}$ & & $N / A$ & & 97.1 & 98.3 & 100 & 7.06 \\
\hline $13 b$ & $\mathrm{C} 32 \mathrm{H}$ & | 596.3448 | & 596 & 83.7 & 100 & 100 & 8.34 \\
\hline $14 a$ & $\mathrm{C} 32 \mathrm{H}$ & 548.3362 & 548.33 & 100 & 100 & 97 & \\
\hline $14 b$ & $\mathrm{C} 31 \mathrm{H} 42 \mathrm{~N} 4 \mathrm{O} 4$ & 534.3206 & $534.3201 \pm$ & 100 & 100 & 100 & $8.15^{a}$ \\
\hline $14 c$ & $\mathrm{C} 32 \mathrm{H} 46 \mathrm{~N} 4 \mathrm{O} 4$ & | 550.3519| & $550.3508 \pm 0.0016$ & 85.6 & 100 & 97.9 & $8.11^{b}$ \\
\hline 14 & & 522.3206 & 522.32 & 97 & 99 & 96 & 8.2 \\
\hline $14 \mathrm{e}$ & 404 & 534.3206 & $534.3217 \pm$ & 98 & 100 & 100 & 8.12 \\
\hline $14 f$ & $\mathrm{C} 31 \mathrm{H} 44 \mathrm{~N} 4 \mathrm{O} 4$ & | 536.3362| & $536.3351 \pm 0.0016$ & 99.2 & 100 & 100 & 8.3 \\
\hline $14 \mathrm{~g}$ & $\mathrm{C} 30 \mathrm{H} 40 \mathrm{~N} 4 \mathrm{O} 4$ & 520.3049 & $520.3057 \pm 0.0016$ & 100 & 100 & 100 & $7.58^{c}$ \\
\hline $14 \mathrm{~h}$ & $\mathrm{C} 31 \mathrm{H} 44 \mathrm{~N} 4 \mathrm{O} 4$ & | 536.3362| & $536.3356 \pm 0.0016$ & 99 & 100 & 100 & $8.02^{d}$ \\
\hline $14 i$ & $\mathrm{C} 30 \mathrm{H} 42 \mathrm{~N} 4 \mathrm{O} 4$ & 522.3206 & $522.3214 \pm c$ & 97 & 100 & 100 & 8.15 \\
\hline $14 k$ & $\mathrm{C} 31 \mathrm{H} 44 \mathrm{~N} 4 \mathrm{O} 4$ & 536.3362 & $536.3372 \pm 0.0016$ & 97 & 100 & 100 & 8.65 \\
\hline $14 \mathrm{~m}$ & $\mathrm{C} 30 \mathrm{H} 42 \mathrm{~N} 4 \mathrm{O} 5$ & | 538.3155 | & $538.3145 \pm 0.0016$ & 100 & 100 & 100 & 7.9 \\
\hline $14 n$ & $\mathrm{C} 29 \mathrm{H} 40 \mathrm{~N} 4 \mathrm{O} 5$ & 524.2998 & $524.3008 \pm 0.0016$ & 92.5 & 100 & 100 & $7.70^{\mathrm{e}}$ \\
\hline
\end{tabular}

(a) Two diastereomers observed, ratio 1:2 (Rt 7.82, $8.15 \mathrm{~min}$.)

(b) Two diastereomers observed, ratio 16:1 (Rt 7.84, $8.10 \mathrm{~min}$.)

(c) Two diastereoemrs observed, ratio 1:1 (Rt 7.58, $7.93 \mathrm{~min}$.)

(d) Two disatereomers observed, ratio 3:1 (Rt 7.60, $8.02 \mathrm{~min}$.)

(e) Two diastereomers observed, ratio 3:1 (Rt 7.70/8.44 min.) 


\section{(f) Table 1 (cont'd)}

\begin{tabular}{|c|c|c|c|c|c|c|c|}
\hline $\begin{array}{c}\text { Compound } \\
\text { Number }\end{array}$ & formula & calc. & found & Purity (\%) & RT \\
\hline $\mathbf{1 5 a}$ & C24H36N4O4 & 444.2736 & $444.2744 \pm 0.0013$ & 96.6 & 100 & 100 & 6.79 \\
$\mathbf{1 5 b}$ & C27H44N4O4 & 488.3362 & $488.3372 \pm 0.0014$ & 83.2 & 75.2 & 75 & $7.87^{\mathrm{a}}$ \\
$\mathbf{1 6 a}$ & C30H42N4O4 & 522.3206 & $522.3198 \pm 0.0016$ & 85.3 & 100 & 89.7 & 9.37 \\
$\mathbf{1 6 b}$ & C3OH48N4O4 & 528.3675 & $528.3663 \pm 0.0016$ & 100 & 100 & 100 & 11.21 \\
$\mathbf{1 6 c}$ & C29H4ON4O4 & 508.3049 & $508.3040 \pm 0.0015$ & 100 & 100 & 100 & 8.45 \\
$\mathbf{1 6 d}$ & C31H44N4O4 & 536.3362 & $536.3356 \pm 0.0016$ & 99.1 & 100 & 97.7 & 10.60 \\
$\mathbf{1 6 e}$ & C32H43N5O4 & 561.3315 & $561.3309 \pm 0.0017$ & 98.4 & 100 & 99.3 & 10.05 \\
$\mathbf{1 6 f}$ & C34H44N4O4 & 572.3362 & $572.3356 \pm 0.0017$ & 86 & 96 & 100 & 11.7 \\
$\mathbf{1 6 i}$ & C31H44N4O5 & 552.3311 & $552.3321 \pm 0.0016$ & 98.8 & 100 & 100 & 9.45 \\
$\mathbf{1 6 g}$ & C32H42N4O4S & 578.2927 & $578.2922 \pm 0.0017$ & 99.5 & 100 & 100 & 11.65 \\
$\mathbf{1 6 h}$ & C34H44N4O4 & 572.3362 & $572.3351 \pm 0.0017$ & 100 & 100 & 100 & 11.72 \\
$\mathbf{1 7 a}$ & C30H41N3O6 & 539.2995 & $539.2990 \pm 0.0016$ & 97.7 & 100 & 100 & 12.41 \\
$\mathbf{1 7 b}$ & C30H41N3O6 & 539.2995 & $539.3000 \pm 0.0016$ & 93 & 100 & 100 & 9.89 \\
$\mathbf{1 7 c}$ & C31H44N4O5 & 552.3311 & $552.3316 \pm 0.0016$ & 92.7 & 100 & 100 & 8.14 \\
$\mathbf{1 7 d}$ & C32H46N4O5 & 566.3468 & $566.3455 \pm 0.0017$ & 99 & 98 & 99 & $11.37^{b}$ \\
$\mathbf{1 7 e}$ & C30H44N4O4 & 524.3362 & $524.3354 \pm 0.0016$ & 94 & 98 & 99 & 7.6 \\
$\mathbf{1 7 f}$ & C30H43N5O5 & 553.3264 & $553.3252 \pm 0.0016$ & NA & 91 & 78.3 & 7.98 \\
$\mathbf{1 7 g}$ & C31H44N4O5 & 552.3311 & $552.3321 \pm 0.0016$ & 100 & 100 & 100 & 7.78 \\
\hline
\end{tabular}

(a) Two diastereomers observed, ratio 1:6.5 (Rt 7.42, $7.87 \mathrm{~min}$.)

(b) Two diastereomers observed, ratio 2:1 (Rt 11.37, $12.29 \mathrm{~min}$.) 


\section{c. NMR characterization of selected macrocycles}

\section{Macrocycle 1}

${ }^{1} \mathrm{H}$ NMR (300 MHz, CD $\left.3 \mathrm{OD}\right) \delta(\mathrm{ppm}) 8.81$ (d, 1H, $\left.9 \mathrm{~Hz}\right) ; 7.69$ (d, 1H, $\left.6 \mathrm{~Hz}\right) ; 7.25-7.19$ $(\mathrm{m}, 3 \mathrm{H}) ; 6.97$ (d, 1H, $7 \mathrm{~Hz}) ; 6.94(\mathrm{~d}, 1 \mathrm{H}, 7 \mathrm{~Hz}) ; 6.73-6.70(\mathrm{~m}, 2 \mathrm{H}) ; 6.57$ (d, 1H, $16 \mathrm{~Hz})$; 6.24 (dt, 1H, $16 \mathrm{~Hz}, 6 \mathrm{~Hz}) ; 4.48-4.41(\mathrm{~m}, 2 \mathrm{H}) ; 4.36-4.25(\mathrm{~m}, 2 \mathrm{H}) ; 4.12$ (dt, 1H, $16 \mathrm{~Hz}, 7$ $\mathrm{Hz}) ; 3.80$ (d, 1H, $9 \mathrm{~Hz})$; 3.59-3.35 (m, 4H); 3.26 (d, 2H, $5 \mathrm{~Hz}) ; 2.11-2.01$ (m, 2H); $1.67-$ 1.31 (m, 3H); 1.13 (d, 3H, $7 \mathrm{~Hz}) ; 1.02$ (d, 3, $7 \mathrm{~Hz}) ; 0.96$ (t, 3H, $7 \mathrm{~Hz})$.

${ }^{13} \mathrm{C}$ NMR (75.5 MHz, CD $\left.{ }_{3} \mathrm{OD}\right) \delta$ (ppm) $174.34 ; 173.54 ; 169.13 ; 158.60 ; 156.56 ; 132.48$; $130.61 ; 130.36 ; 129.81 ; 128.36 ; 128.32 ; 127.48 ; 124.00 ; 122.85 ; 116.83 ; 112.62 ; 64.32$; $63.89 ; 61.78 ; 54.18 ; 48.11 ; 43.96 ; 36.81 ; 34.32 ; 30.23 ; 20.55 ; 20.22 ; 19.35 ; 13.67$.

\section{Macrocycle $12 f$}

${ }^{1} \mathrm{H}$ NMR (300 MHz, CD3OD) $\delta(\mathrm{ppm}) 8.80$ (d, 1H, $\left.9 \mathrm{~Hz}\right) ; 7.73$ (d, 1H, $\left.6 \mathrm{~Hz}\right) ; 7.45-7.405$ $(\mathrm{m}, 2 \mathrm{H}) ; 7.35-7.31(\mathrm{~m}, 3 \mathrm{H}) ; 7.26-7.20(\mathrm{~m}, 2 \mathrm{H}) ; 6.63(\mathrm{~d}, 1 \mathrm{H}, 16 \mathrm{~Hz}) ; 6.30(\mathrm{dt}, 1 \mathrm{H}, 16 \mathrm{~Hz}$, $6 \mathrm{~Hz}) ; 4.51-4.40(\mathrm{~m}, 2 \mathrm{H}) ; 4.38-4.33(\mathrm{~m}, 1 \mathrm{H}) ; 4.27$ (dd, 1H, $10 \mathrm{~Hz} ; 2 \mathrm{~Hz}) ; 4.10$ (dt, 1H, 16 $\mathrm{Hz}, 7 \mathrm{~Hz}) ; 3.82$ (d, 1H, $9 \mathrm{~Hz}) ; 3.56$ (dt, 1H, $13 \mathrm{~Hz}, 2 \mathrm{~Hz}) ; 3.49-3.30$ (m, 4H); 2.12-2.00 $(\mathrm{m}, 2 \mathrm{H}) ; 1.64-1.30(\mathrm{~m}, 3 \mathrm{H}) ; 1.12(\mathrm{~d}, 3 \mathrm{H}, 7 \mathrm{~Hz}) ; 1.01$ (d, 3H, $7 \mathrm{~Hz}) ; 0.96$ (t, 3H, $7 \mathrm{~Hz})$.

${ }^{13} \mathrm{C}$ NMR (75.5 MHz, CD $\left.{ }_{3} \mathrm{OD}\right) \delta(\mathrm{ppm}) 174.38 ; 173.45 ; 169.09 ; 156.67 ; 134.25 ; 131.36$; $130.64 ; 130.44 ; 130.17 ; 129.86 ; 129.20 ; 128.30 ; 127.50 ; 122.87 ; 112.63 ; 64.39 ; 63.87$; $61.94 ; 51.21 ; 48.39 ; 44.07 ; 37.73 ; 34.37 ; 30.34 ; 20.60 ; 20.23 ; 19.34 ; 13.73$.

\section{Macrocycle 12t}

${ }^{1} \mathrm{H}$ NMR (300 MHz, CD $\left.3 \mathrm{OD}\right) \delta(\mathrm{ppm}) 8.83$ (d, 1H, $\left.9 \mathrm{~Hz}\right) ; 7.70$ (d, 1H, $\left.7 \mathrm{~Hz}\right) ; 7.25-7.18$ (m, 4H); 6.96 (dd, 2H, $7 \mathrm{~Hz}, 5 \mathrm{~Hz}) ; 6.72$ (d, 2H, $8 \mathrm{~Hz}) ; 6.57$ (d, 1H, $16 \mathrm{~Hz}) ; 6.23$ (dt, 1H, $16 \mathrm{~Hz}, 7 \mathrm{~Hz}) ; 4.51$ (ddd, 1H, $12 \mathrm{~Hz} ; 9 \mathrm{~Hz}, 3 \mathrm{~Hz}) ; 4.43$ (t, 1H, $5 \mathrm{~Hz}) ; 4.38-4.24$ (m, 2H); $4.11(\mathrm{dt}, 1 \mathrm{H}, 15 \mathrm{~Hz}, 7 \mathrm{~Hz}) ; 3.57$ (dt, 1H, 13Hz, $1 \mathrm{~Hz}) ; 3.49-3.37$ (m, 2H); 3.27 (d, 2H, 5 $\mathrm{Hz})$; 2.12-2.00 (m, 1H); 1.85 (ddd, 1H, $13 \mathrm{~Hz}, 10 \mathrm{hz}, 3 \mathrm{~Hz}$ ); 1.77-1.67 (m, 1H); 1.58 (dt, $1 \mathrm{H}, 13 \mathrm{~Hz}, 3 \mathrm{~Hz}) ; 1.13$ (d, 3H, $6 \mathrm{~Hz}) ; 1.02$ (d, 3H, $7 \mathrm{~Hz}) ; 0.98$ (d, 3H, $6 \mathrm{~Hz}) ; 0.94$ (d, 3H, $6 \mathrm{~Hz})$.

${ }^{13} \mathrm{C}$ NMR (75.5 MHz, CD $\left.{ }_{3} \mathrm{OD}\right) \mathrm{d}(\mathrm{ppm}) 174.66 ; 173.42 ; 169.11 ; 158.62 ; 156.57 ; 132.51$; $130.65 ; 130.44 ; 129.82 ; 128.38 ; 127.47 ; 123.96 ; 122.86 ; 116.85 ; 122.64 ; 64.32 ; 63.92$;

$61.76 ; 52.87 ; 48.09 ; 44.03 ; 44.03 ; 41.27 ; 36.80 ; 30.24 ; 25.93 ; 23.89 ; 20.77 ; 20.25 ; 19.27$.

\section{Macrocycle 14d}

${ }^{1} \mathrm{H}$ NMR $\left(300 \mathrm{MHz}, \mathrm{CD}_{3} \mathrm{OD}\right) \delta(\mathrm{ppm}) 8.68(\mathrm{~d}, 1 \mathrm{H}, 9 \mathrm{~Hz}): 8.04(\mathrm{t}, 1 \mathrm{H}, 6 \mathrm{~Hz}) ; 7.28 \mathrm{~d}, 2 \mathrm{H}$, $8 \mathrm{~Hz}) ; 7.20-7.12(\mathrm{~m}, 4 \mathrm{H}) ; 6.78$ (d, 2H, $8 \mathrm{~Hz}) ; 4.45$ (dt, 1H, $11 \mathrm{~Hz} ; 3 \mathrm{~Hz}) ; 4.34$ (t, 1H, 7 $\mathrm{Hz}) ; 3.79$ (d, 1H, $8 \mathrm{~Hz})$; 3.62-3.49 (m, 1H); 3.32-3.26 (m, 2H); 3.22-3.14 (m, 3H); 2.99$2.73(\mathrm{~m}, 3 \mathrm{H}) ; 2.53-2.42(\mathrm{~m}, 1 \mathrm{H}) ; 2.12-1.28(\mathrm{~m}, 9 \mathrm{H}) ; 1.01-0.94(\mathrm{~m}, 9 \mathrm{H})$.

${ }^{13} \mathrm{C}$ NMR (75.5 MHz, CD $\left.{ }_{3} \mathrm{OD}\right) \delta$ (ppm) $173.97 ; 173.94 ; 173.13 ; 173.04 ; 169.33 ; 158.59$; $141.10 ; 137.48 ; 132.11 ; 130.67 ; 130.07 ; 127.92 ; 127.55 ; 125.37 ; 116.94 ; 63.53 ; 63.49$; $62.21 ; 53.98 ; 53.89 ; 47.20 ; 41.88 ; 36.92 ; 33.96 ; 33.45 ; 32.26 ; 30.44 ; 28.93 ; 26.78 ; 20.49$; $19.95 ; 19.41 ; 13.74$. 


\section{Macrocycle 14m}

${ }^{1} \mathrm{H} \mathrm{NMR}\left(300 \mathrm{MHz}, \mathrm{CD}_{3} \mathrm{OD}\right) \delta(\mathrm{ppm}) 8.84(\mathrm{~d}, 1 \mathrm{H}, 9 \mathrm{~Hz}) ; 7.46$ (d, 1H, $\left.6 \mathrm{~Hz}\right) ; 7.20-7.09$ (m, 4H); 6.90 (t, 2H, $8 \mathrm{~Hz}) ; 6.66$ (d, 2H, $8 \mathrm{~Hz}) ; 4.48$ (t, 1H, $4 \mathrm{~Hz}) ; 4.47-4.38(\mathrm{~m}, 1 \mathrm{H})$; 4.26 (d, 2H, $7 \mathrm{~Hz}) ; 3.81$ (d, 1H, $9 \mathrm{~Hz}) ; 3.63$ (d, 1H); 3.43-3.23 (m, 4H); 2.84 (dt, 1H. 13 $\mathrm{Hz} ; 6 \mathrm{~Hz}) ; 2.74-2.68 \mathrm{~m}, 1 \mathrm{H}) ; 2.20$ (dt, 1H, $12 \mathrm{~Hz} ; 3 \mathrm{~Hz}) ; 2.12-2.04$ (m, 2H); 1.66-1.29 (m, 5H); 1.16 (d, 3H, $7 \mathrm{~Hz}) ; 1.04$ (d, 3H, $7 \mathrm{~Hz}) ; 0.97$ (t, 3H, $7 \mathrm{~Hz})$.

${ }^{13} \mathrm{NMR}\left(75.5 \mathrm{MHz}, \mathrm{CD}_{3} \mathrm{OD}\right) \delta(\mathrm{ppm}) 174.87 ; 173.62 ; 158.66 ; 156.59 ; 132.65 ; 131.60$; $131.41 ; 128.60 ; 123.36$; $122.82 ; 116.86 ; 111.51 ; 64.09 ; 63.20 ; 61.37$; 54.26; 48.30; $42.69 ; 36.81 ; 34.32 ; 31.20 ; 30.14 ; 29.01 ; 20.58 ; 20.29 ; 19.43 ; 12.67$.

\section{Macrocycle 16b}

${ }^{1} \mathrm{H}$ NMR $\left(300 \mathrm{MHz}, \mathrm{CD}_{3} \mathrm{OD}\right) \delta(\mathrm{ppm}) 8.76(\mathrm{~d}, 1 \mathrm{H}, 9 \mathrm{~Hz}) ; 7.91(\mathrm{~d}, 1 \mathrm{H}, 6 \mathrm{~Hz}) ; 7.21-7.16$ (m, 2H); 6.94-6.89 (m, 2H); 4.40-4.14 (m, 4H); $3.86(\mathrm{~d}, 1 \mathrm{H}, 8 \mathrm{~Hz}) ; 3.60-3.53(\mathrm{~m}, 2 \mathrm{H})$; 3.35-3.26 (m, 2H); 3.17-3.08 (m, 1H); 3.03 (dd, $1 \mathrm{H}, 13 \mathrm{~Hz} ; 5 \mathrm{~Hz}) ; 2.56$ (dt, 1H, $13 \mathrm{~Hz} ; 3$ $\mathrm{Hz}) ; 2.28-1.98$ (m, 3H); 1.90-1.12 (m, 9H); 1.14 (d, 3H, $7 \mathrm{~Hz}) ; 1.05$ (d, 3H, $7 \mathrm{~Hz}) ; 0.95$ (t, $3 \mathrm{H}, 7 \mathrm{~Hz})$.

${ }^{13} \mathrm{C}$ NMR $\left(75.5 \mathrm{MHz}, \mathrm{CD}_{3} \mathrm{OD}\right) \delta(\mathrm{ppm}) 174.80 ; 173.26 ; 156.97 ; 131.81 ; 131.37 ; 128.49$; $122.70 ; 111.56 ; 63.59 ; 60.05 ; 54.13 ; 48.63 ; 42.61 ; 39.67 ; 34.47 ; 34.38 ; 34.15 ; 33.67$; $30.87 ; 30.40 ; 29.16 ; 27.32 ; 27.19 ; 26.99 ; 20.56 ; 20.20 ; 19.21 ; 13.69$.

\section{Macrocycle 16e}

${ }^{1} \mathrm{H}$ NMR $\left(300 \mathrm{MHz}, \mathrm{CD}_{3} \mathrm{OD}\right) \delta(\mathrm{ppm}) 10.7(\mathrm{~s}, 1 \mathrm{H}) ; 8.80(\mathrm{~d}, 1 \mathrm{H}, 9 \mathrm{~Hz}) ; 7.75(\mathrm{~d}, 1 \mathrm{H}, 9$ $\mathrm{Hz}) ; 7.54$ (d, 1H, $6 \mathrm{~Hz}) ; 7.38-7.36$ (m, 2H); 7.15-7.06 (m, 2H); 7.05-6.99 (m, 2H); 6.88$6.82(\mathrm{~m}, 2 \mathrm{H}) ; 4.57(\mathrm{t}, 1 \mathrm{H}, 6 \mathrm{~Hz}) ; 4.43-4.35(\mathrm{~m}, 1 \mathrm{H}) ; 4.27-4.18(\mathrm{~m}, 2 \mathrm{H}) ; 3.80(\mathrm{~d}, 1 \mathrm{H}, 9$ $\mathrm{Hz}) ; 3.64-3.55$ (m, 3H); 3.44-3.25 (m, 2H); 2.50 (dt, $1 \mathrm{H}, 12 \mathrm{~Hz} ; 6 \mathrm{~Hz}) ; 2.77-2.55$ (m, $1 \mathrm{H}) ; 2.22-1.87$ (m, 3H); 1.64-1.29 (m, 5H); 1.12 (d, 3H, $6 \mathrm{~Hz}) ; 1.03$ (d, 3H, $6 \mathrm{~Hz}) ; 0.96$ $(\mathrm{t}, 3 \mathrm{H}, 6 \mathrm{~Hz})$.

${ }^{13} \mathrm{C}$ NMR $\left(75.5 \mathrm{MHz}, \mathrm{CD}_{3} \mathrm{OD}\right) \delta(\mathrm{ppm}) 174.68 ; 173.66 ; 169.41 ; 156.68 ; 138.05 ; 31.41$; $131.28 ; 128.49 ; 127.45 ; 123.01 ; 122.62 ; 120.72 ; 118.94 ; 112.73 ; 111.46 ; 105.67 ; 63.98$; $63.37 ; 61.82 ; 54.35 ; 42.14 ; 34.15 ; 31.02 ; 30.16 ; 28.82 ; 27.86 ; 20.59 ; 20.23 ; 19.37 ; 13.69$.

\section{Macrocycle $16 \mathrm{~g}$}

${ }^{1} \mathrm{H}$ NMR $\left(300 \mathrm{MHz}, \mathrm{CD}_{3} \mathrm{OD}\right) \delta(\mathrm{ppm}) 8.75(\mathrm{~d}, 1 \mathrm{H}, 9 \mathrm{~Hz}) ; 8.03(\mathrm{~d}, 1 \mathrm{H}, 9 \mathrm{~Hz}) ; 7.92(\mathrm{~d}$, $1 \mathrm{H}, 6 \mathrm{~Hz}) ; 7.78$ (s, 1H); 7.73 (bd, 1H, $6 \mathrm{~Hz}) ; 7.48-7.36$ (m, $2 \mathrm{H}): 7.20-7.10$ (m, 2H); 6.93-6.86 (m, 2H); $4.54(\mathrm{t}, 1 \mathrm{H}, 6 \mathrm{~Hz}) ; 4.45-4.37(\mathrm{~m}, 1 \mathrm{H}) ; 4.28-4.23(\mathrm{~m}, 2 \mathrm{H}) ; 3.84(\mathrm{~d}$, $1 \mathrm{H}) ; 3.65-3.59$ (m, 3H); 3.50-3.35 (m, 2H); 2.36 (dt, $1 \mathrm{H}, 12 \mathrm{~Hz} ; 3 \mathrm{~Hz}) ; 2.12-1.97$ (m, 2H); 1.97-1.77 (m, 1H); 1.77-1.28 (m, H); 1.09 (d, 3H, $6 \mathrm{~Hz}) ; 1.00$ (d, 3H, $6 \mathrm{~Hz}) ; 0.97$ (t, $3 \mathrm{H}, 9 \mathrm{~Hz})$.

${ }^{13} \mathrm{C}$ NMR $\left(75.5 \mathrm{MHz}, \mathrm{CD}_{3} \mathrm{OD}\right) \delta(\mathrm{ppm}) 174.71 ; 173.10 ; 156.85 ; 141.86 ; 139.78 ; 131.57$; 131.36 ; $128.73 ; 128.48 ; 125.87 ; 125.73 ; 124.02 ; 122.69 ; 111.52 ; 63.84 ; 63.57 ; 60.99$; $54.18 ; 48.71 ; 42.50 ; 34.20 ; 30.91 ; 30.52 ; 30.37 ; 29.01 ; 20.56 ; 20.09 ; 19.22 ; 13.70$. 


\section{Macrocycle 16h}

${ }^{1} \mathrm{H}$ NMR (300 MHz, CD $\left.3 \mathrm{OD}\right) \delta(\mathrm{ppm}) 8.70$ (d, 1H, $\left.6 \mathrm{~Hz}\right) ; 8.26$ (d, 1H, $\left.9 \mathrm{~Hz}\right) ; 7.95-7.86$ $(\mathrm{m}, 3 \mathrm{H})$; 7.66-7.60 (m, 2H); 7.56-7.46 (m, 2H); 7.20-7.13 (m, 2H); 6.93-6.86 (m, 2H); 4.50 (t, 1H, $6 \mathrm{~Hz}) ; 4.45-4.37(\mathrm{~m}, 1 \mathrm{H}) ; 4.24-4.20(\mathrm{~m}, 2 \mathrm{H}) ; 3.85-3.79(\mathrm{~m}, 2 \mathrm{H}) ; 3.65$ (dd, $1 \mathrm{H}, 15 \mathrm{~Hz} ; 9 \mathrm{~Hz}) ; 3.58-3.49$ (m, 2H); 3.65-3.47 (m, 1H); 3.09-2.98 m, 1H); 2.89 (dt, 1H, 12 z; $6 \mathrm{~Hz}) ; 2.47$ (dt, 1H, 12 Hz; $3 \mathrm{~Hz}) ; 2.13-1.71$ (m, 4H); 1.68-1.28 (m, $3 \mathrm{H}) ; 0.99$ (d, $3 \mathrm{H}, 6 \mathrm{~Hz}) ; 0.98$ (t, 3H, $6 \mathrm{~Hz}) ; 0.90$ (d, 3H, $6 \mathrm{~Hz})$.

${ }^{13} \mathrm{C}$ NMR (75.5 MHz, CD $\left.{ }_{3} \mathrm{OD}\right) \delta$ (ppm) $174.70 ; 157.02 ; 135.56 ; 133.18 ; 131.68 ; 131.25$; $130.39 ; 130.15 ; 129.75 ; 128.43 ; 127.99 ; 127.09 ; 126.84 ; 124.34 ; 122.60 ; 111.56 ; 63.50$; $61.82 ; 54.20 ; 42.33 ; 42.15 ; 34.95 ; 34.16 ; 30.75 ; 30.39 ; 29.14 ; 20.57 ; 19.92 ; 19.00 ; 13.71$.

\section{Macrocycle 16i}

${ }^{1} \mathrm{H}$ NMR (300 MHz, CD $\left.3 \mathrm{OD}\right) \delta(\mathrm{ppm}) 8.77$ (d, 1H, $\left.9 \mathrm{~Hz}\right) ; 7.75$ (d, 1H, $\left.3 \mathrm{~Hz}\right) ; 7.21-7.05$ (m, 4H); 6.87-6.73 (m, 4H); 4.46-4.38 (m, 1H); 4.15-4.00 (m, 3H); 3.79 (d, 1H, 12Hz); $3.74(\mathrm{~s}, 3 \mathrm{H}) ; 3.29-3.04(\mathrm{~m}, 5 \mathrm{H}) ; 2.71(\mathrm{dt}, 1 \mathrm{H}, 12 \mathrm{~Hz} ; 6 \mathrm{~Hz}) ; 2.63-2.53(\mathrm{~m}, 1 \mathrm{H}) ; 2.20$ (dt, $1 \mathrm{H}, 12 \mathrm{~Hz} ; 3 \mathrm{~Hz}) ; 2.13-1.98$ (m, 2H); 1.66-1.33 (m, 5H); 1.12 (s, 3H, $6 \mathrm{~Hz}) ; 1.02$ (d, 3H, $6 \mathrm{~Hz}) ; 0.96$ (t, 3H, $6 \mathrm{~Hz})$.

${ }^{1} 3 \mathrm{C}$ NMR (75.5 MHz, $\left.\mathrm{CD}_{3} \mathrm{OD}\right) \delta(\mathrm{ppm}) 174.80 ; 174.21 ; 160.44 ; 127.31 ; 132.47 ; 131.46$; $131.32 ; 128.43 ; 122.11 ; 114.89 ; 111.41 ; 65.88 ; 63.69 ; 61.48 ; 55.59 ; 54.20 ; 48.10 ; 42.40$; $38.48 ; 34.31 ; 31.32 ; 30.09 ; 29.08 ; 20.57 ; 20.26 ; 19.52 ; 13.67$.

\section{Macrocycle 16k}

${ }^{1} \mathrm{H}$ NMR (300 MHz, CD 3 OD) $\delta(\mathrm{ppm}) 7.48$ (d, 1H, $\left.5 \mathrm{~Hz}\right) ; 7.22-7.12(\mathrm{~m}, 4 \mathrm{H}) ; 6.91$ (t, 2H, $7 \mathrm{hz}$ ); 6.72-6.67 (m, 2H); 5.20 (dd, 1H, $7 \mathrm{~Hz}, 4 \mathrm{~Hz}) ; 4.46$ (t, 1H, $5 \mathrm{~Hz}) ; 4.30-4.23$ (m, $2 \mathrm{H}) ; 4.03$ (d, 1H, $8 \mathrm{~Hz}) ; 3.60$ (dt, 1H, $13 \mathrm{hz}, 1 \mathrm{~Hz}) ; 3.48-3.36(\mathrm{~m}, 2 \mathrm{H}) ; 3.28-3.24$ (m, 2H); 2.86-2.69 (m, 2H); 2.33 (dt, 1H, $11 \mathrm{~Hz} ; 5 \mathrm{~Hz}) ; 2.14$ (h, 1H, $7 \mathrm{~Hz}) ; 1.94-1.80$ (m, 2H); 1.67-1.57 (m, 2H); 1.45 (h, 2H, $7 \mathrm{~Hz}) ; 1.13$ (d, 3H, $7 \mathrm{~Hz}) ; 1.03$ (d, 3H, $7 \mathrm{~Hz}) ; 0.96$ (t, 3H, $7 \mathrm{~Hz})$.

${ }^{13} \mathrm{C}$ NMR (75.5 MHz, CD $\left.{ }_{3} \mathrm{OD}\right) \delta$ (ppm) $172.57 ; 172.26 ; 158.64 ; 156.73 ; 132.41 ; 131.55$; $131.32 ; 128.59 ; 122.76 ; 116.87 ; 111.57 ; 75.10 ; 63.35 ; 62.35 ; 61.68 ; 48.33 ; 42.16 ; 42.01$; $37.01 ; 34.99 ; 30.91 ; 30.54 ; 28.98 ; 19.81 ; 19.52 ; 18.95 ; 13.88$. 


\section{Biological assays}

a. Competitive radioligand binding assay (hMOT-r)

Materials:

Membranes were prepared from CHO cells stably transfected with the human motilin receptor and utilized at a quantity of $1.5 \mu \mathrm{g}$ /assay point. [PerkinElmer ${ }^{\mathrm{TM}}$ SignalScreen Product \#6110544]

$\left[{ }^{125} \mathrm{I}\right]$-Motilin (PerkinElmer, \#NEX-378); final concentration: 0.04-0.06 nM

Motilin (Bachem $\left.{ }^{\mathrm{TM}}, \# \mathrm{H}-4385\right)$; final concentration: $1 \mu \mathrm{M}$

Multiscreen Harvest plates-GF/B (Millipore ${ }^{\mathrm{TM}}$, \#MAHFB1H60)

Deep-well polypropylene titer plate (Beckman Coulter $^{\mathrm{TM}}$, \#267006)

TopSeal-A (PerkinElmer, \#6005185)

Bottom seal (Millipore, \#MATAH0P00)

MicroScint-0 (PerkinElmer, \#6013611)

Binding Buffer: $50 \mathrm{mM}$ Tris- $\mathrm{HCl}$ (pH 7.4), 10 mM MgCl $2,1 \mathrm{mM}$ EDTA, 0.1\% BSA

\section{Assay Volumes:}

$150 \mu \mathrm{L}$ of membranes diluted in binding buffer

$10 \mu \mathrm{L}$ of compound diluted in binding buffer

$10 \mu \mathrm{L}$ of radioligand ([ $\left.{ }^{125} \mathrm{I}\right]$-Motilin) diluted in binding buffer

Final Test Concentrations ( $\mathrm{N}=11)$ for Compounds:

$10,5,2,1,0.5,0.2,0.1,0.05,0.02,0.01,0.005 \mu \mathrm{M}$.

Compound Handling:

Compounds were provided frozen on dry ice at a stock concentration of $10 \mathrm{mM}$ diluted in $100 \% \mathrm{DMSO}$ and stored at $-20^{\circ} \mathrm{C}$ until the day of testing. On the test day, compounds were allowed to thaw at room temperature and than diluted in assay buffer according to the desired test concentrations. Under these conditions, the maximum final DMSO concentration in the assay was $0.5 \%$.

Assay Protocol:

In deep-well plates, diluted cell membranes $(1.5 \mu \mathrm{g} / \mathrm{mL})$ are combined with $10 \mu \mathrm{L}$ of either binding buffer (total binding, $\mathrm{N}=5$ ), $1 \mu \mathrm{M}$ motilin (non-specific binding, $\mathrm{N}=3$ ) or the appropriate concentration of test compound. The reaction is initiated by addition of $10 \mu$ of $\left[{ }^{125} \mathrm{I}\right]$-motilin (final conc. $0.04-0.06 \mathrm{nM}$ ) to each well. Plates are sealed with TopSeal-A, vortexed gently and incubated at room temperature for 2 hours. The reaction is arrested by filtering samples through pre-soaked $(0.3 \%$ polyethyleneimine, $2 \mathrm{~h})$

Multiscreen Harvest plates using a Tomtec Harvester, washed 9 times with $500 \mu \mathrm{L}$ of cold $50 \mathrm{mM}$ Tris- $\mathrm{HCl}$ ( $\mathrm{pH} 7.4$ ), and than plates are air-dried in a fumehood for 30 minutes. A bottom seal is applied to the plates prior to the addition of $25 \mu \mathrm{L}$ of MicroScint-0 to each well. Plates are than sealed with TopSeal-A and counted for $30 \mathrm{sec}$ per well on a TopCount Microplate Scintillation and Luminescence Counter (PerkinElmer) where results are expressed as counts per minute (cpm). 
Data are analyzed by GraphPad ${ }^{\mathrm{TM}}$ Prism (GraphPad Software, San Diego, CA) using a variable slope non-linear regression analysis. $K_{i}$ values were calculated using a $K_{d}$ value of $0.16 \mathrm{nM}$ for $\left[{ }^{125} \mathrm{I}\right]$-motilin (previously determined during membrane characterization).

$\mathrm{D}_{\max }=1$ - test concentration with maximal displacement - non-specific binding $\mathrm{x} 100$ total binding - non-specific binding

where total and non-specific binding represent the cpm obtained in the absence or presence of $1 \mu \mathrm{M}$ motilin, respectively.

Materials:

\section{b. Aequorin functional assay (hMOT-r)}

Membranes were prepared using AequoScreen ${ }^{\mathrm{TM}}$ (EUROSCREEN, Belgium) cell lines expressing the human motilin receptor (cell line ES-380-A; receptor accession

\#AF034632). This cell line is constructed by transfection of the human motilin receptor into CHO-K1 cells co-expressing $\mathrm{G}_{\alpha 16}$ and the mitochondrially targeted Aequorin (Ref \#ES-WT-A5).

Motilin (Bachem, \#H-4385)

Assay buffer: DMEM-F12 (Dulbeccoe's Modified Eagles Medium) with 15 mM HEPES and $0.1 \% \mathrm{BSA}(\mathrm{pH} 7.0)$

Coelenterazine (Molecular Probes ${ }^{\mathrm{TM}}$, Leiden, The Netherlands)

Final Test Concentrations $(\mathrm{N}=5)$ for Compounds:

$10,3.16,1,0.316,0.1 \mu \mathrm{M}$.

Compound Handling:

Compounds were provided as dry films at a quantity of approximately $1.2 \mu \mathrm{mol}$ in preformatted 96-well plates. Compounds were dissolved in 100\% DMSO at a concentration of $10 \mathrm{mM}$ and stored at $-20^{\circ} \mathrm{C}$ until further use. Daughter plates were prepared at a concentration of $500 \mu \mathrm{M}$ in $30 \%$ DMSO with $0.1 \%$ BSA and stored at $-20^{\circ} \mathrm{C}$ until testing. On the test day, compounds were allowed to thaw at room temperature and than diluted in assay buffer according to the desired test concentrations. Under these conditions, the maximum final DMSO concentration in the assay was $0.6 \%$.

Cell Preparation:

Cells are collected from culture plates with $\mathrm{Ca}^{2+}$ and $\mathrm{Mg}^{2+}$-free phosphate buffered saline (PBS) supplemented with $5 \mathrm{mM}$ EDTA, pelleted for 2 minutes at $1000 \mathrm{xg}$, resuspended in assay buffer (see above) at a density of $5 \times 10^{6}$ cells $/ \mathrm{mL}$ and incubated overnight in the presence of $5 \mu \mathrm{M}$ coelenterazine. After loading, cells were diluted with assay buffer to a concentration of $5 \times 10^{5}$ cells $/ \mathrm{mL}$.

Assay Protocol:

For agonist testing, $50 \mu \mathrm{l}$ of the cell suspension was mixed with $50 \mu \mathrm{l}$ of the appropriate concentration of test compound or motilin (reference agonist) in 96-well plates (duplicate samples). The emission of light resulting from receptor activation was recorded using the 
Functional Drug Screening System 6000 'FDSS 6000’ (Hamamatsu Photonics K.K., Japan).

For antagonist testing, an approximate EC80 concentration of motilin (i.e. $0.5 \mathrm{nM} ; 100$ $\mu \mathrm{L}$ ) was injected onto the cell suspension containing the test compounds (duplicate samples) 15-30 minutes after the end of agonist testing and the consequent emission of light resulting from receptor activation was measured as described in the paragraph above.

Results are expressed as Relative Light Units (RLU). Concentration response curves were analyzed using GraphPad Prism (GraphPad Software, San Diego, CA) by non-linear regression analysis (sigmoidal dose-response) based on the equation $\mathrm{E}=\mathrm{E}_{\max } /\left(1+\mathrm{EC}_{50} / \mathrm{C}\right) \mathrm{n}$ where $E$ is the measured RLU value at a given agonist concentration $(C), E_{\max }$ is the maximal response, $\mathrm{EC}_{50}$ is the concentration producing $50 \%$ stimulation and $\mathrm{n}$ is the slope index. For agonist testing, results for each concentration of test compound were expressed as percent activation relative to the signal induced by motilin at a concentration equal to the $\mathrm{EC}_{80}$ (i.e. $0.5 \mathrm{nM}$ ). For antagonist testing, results for each concentration of test compound were expressed as percent inhibition relative to the signal induced by motilin at a concentration equal to the $\mathrm{EC}_{80}$ (i.e. $0.5 \mathrm{nM}$ ).

\section{c. Ex vivo assay (rabbit duodenum contractility assay)}

Duodenal segments were vertically suspended in organ chambers of $10 \mathrm{~mL}$ filled with Krebs buffer and connected to an isotonic force transducer, with a preload of $1 \mathrm{~g}$. After a stabilization period, the muscle strips were challenged with $10^{-4} \mathrm{M}$ acetylcholine and washed. This was repeated until a stable maximal contraction was obtained (2-3 times), with an interval of at least 20 minutes.

After a stable base line was reached, test compounds were added to the bath. After 15 min incubation, a dose response to motilin was recorded by adding logarithmically increasing concentrations of motilin to the bath (final concentration $10^{-9}$ to $10^{-6} \mathrm{M}$ ). A blank experiment (no test compound present) was also performed. At the end of the dose response curve, a supramaximal dose of acetylcholine $\left(10^{-4} \mathrm{M}\right)$ was given and this response was used as a reference (100\% contraction).

The results of experiments at different concentrations of test compound were combined and analyzed to derive the $\mathrm{pA}_{2}$ value from the Schild plot. 


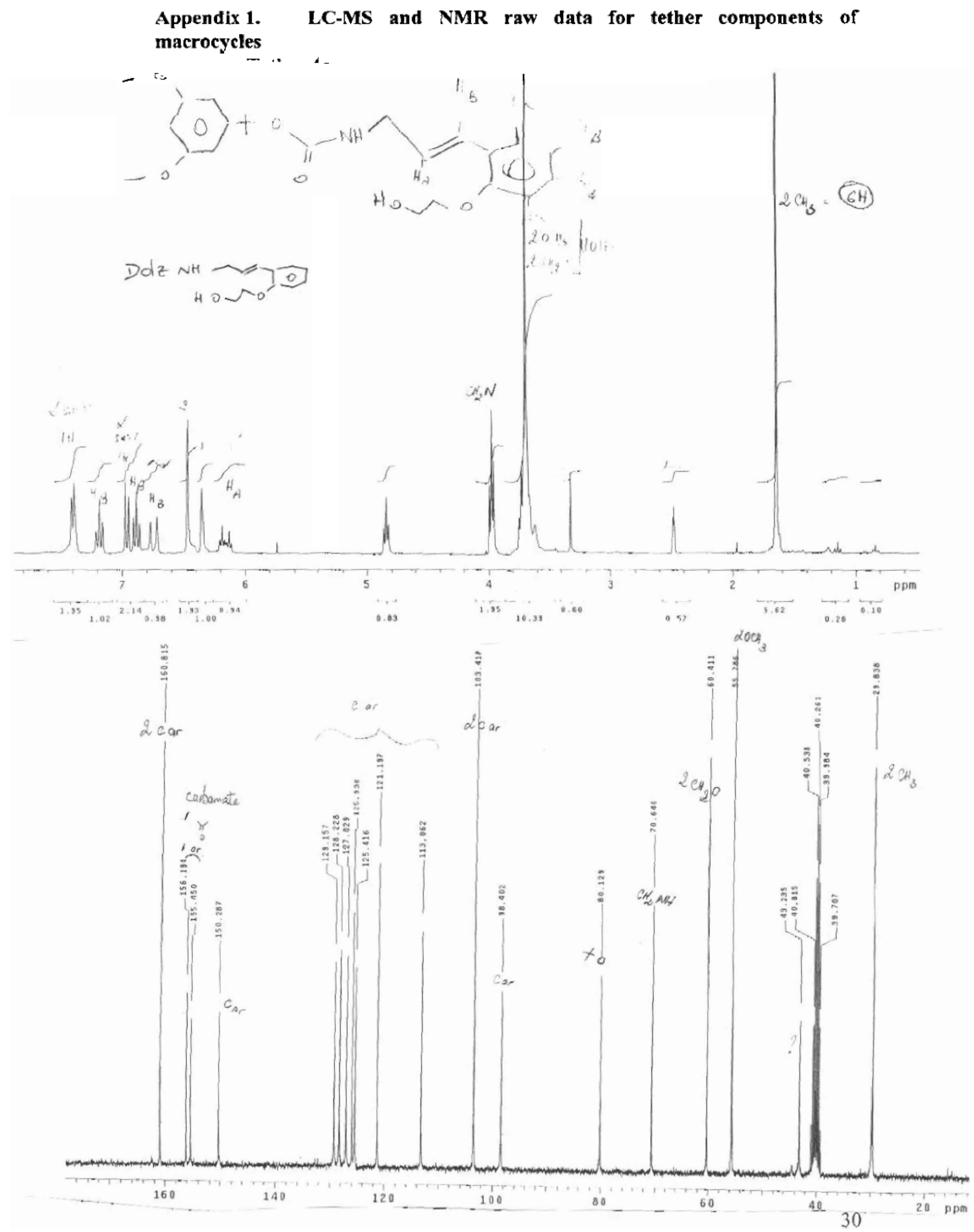




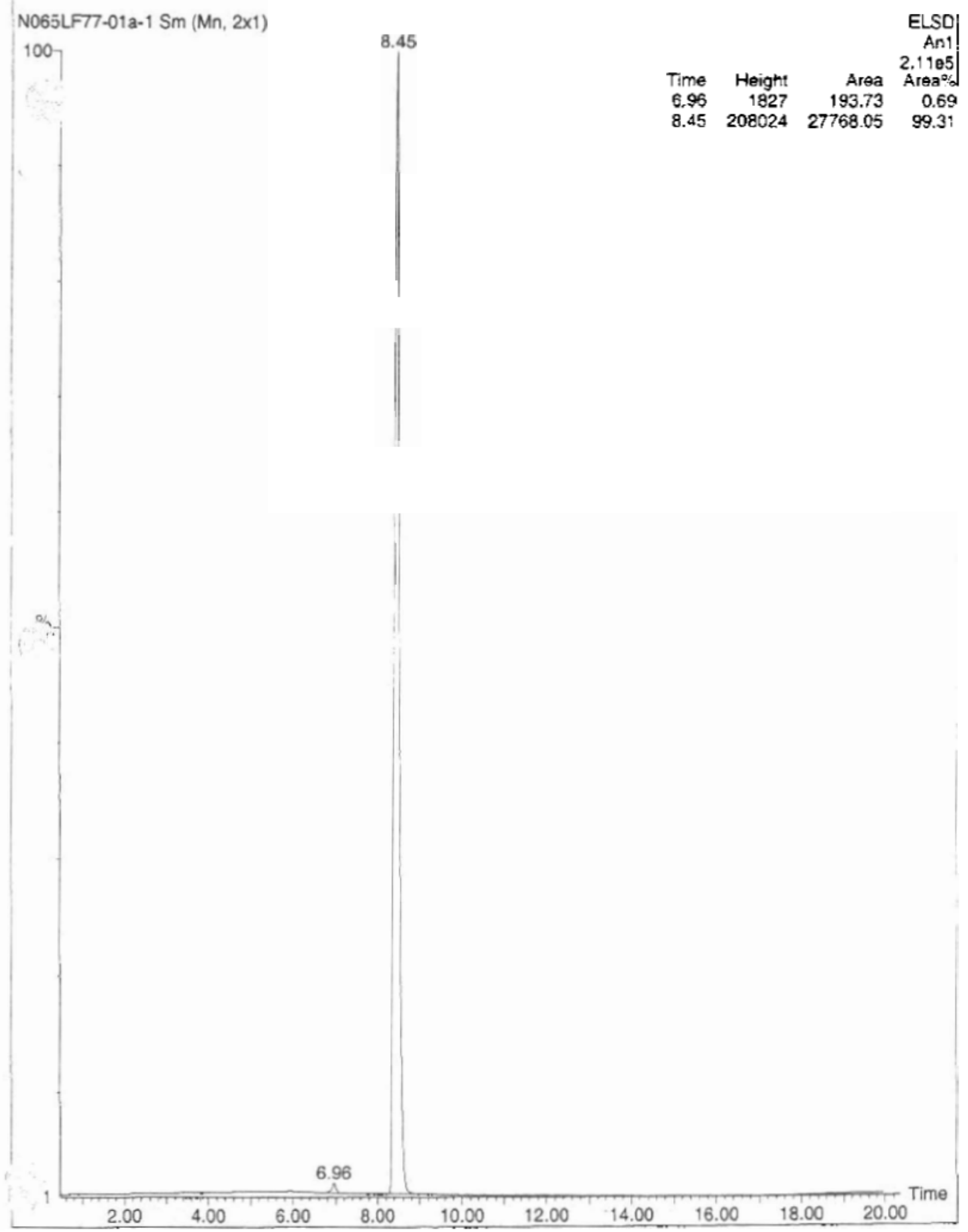


b. Tether $4 b$
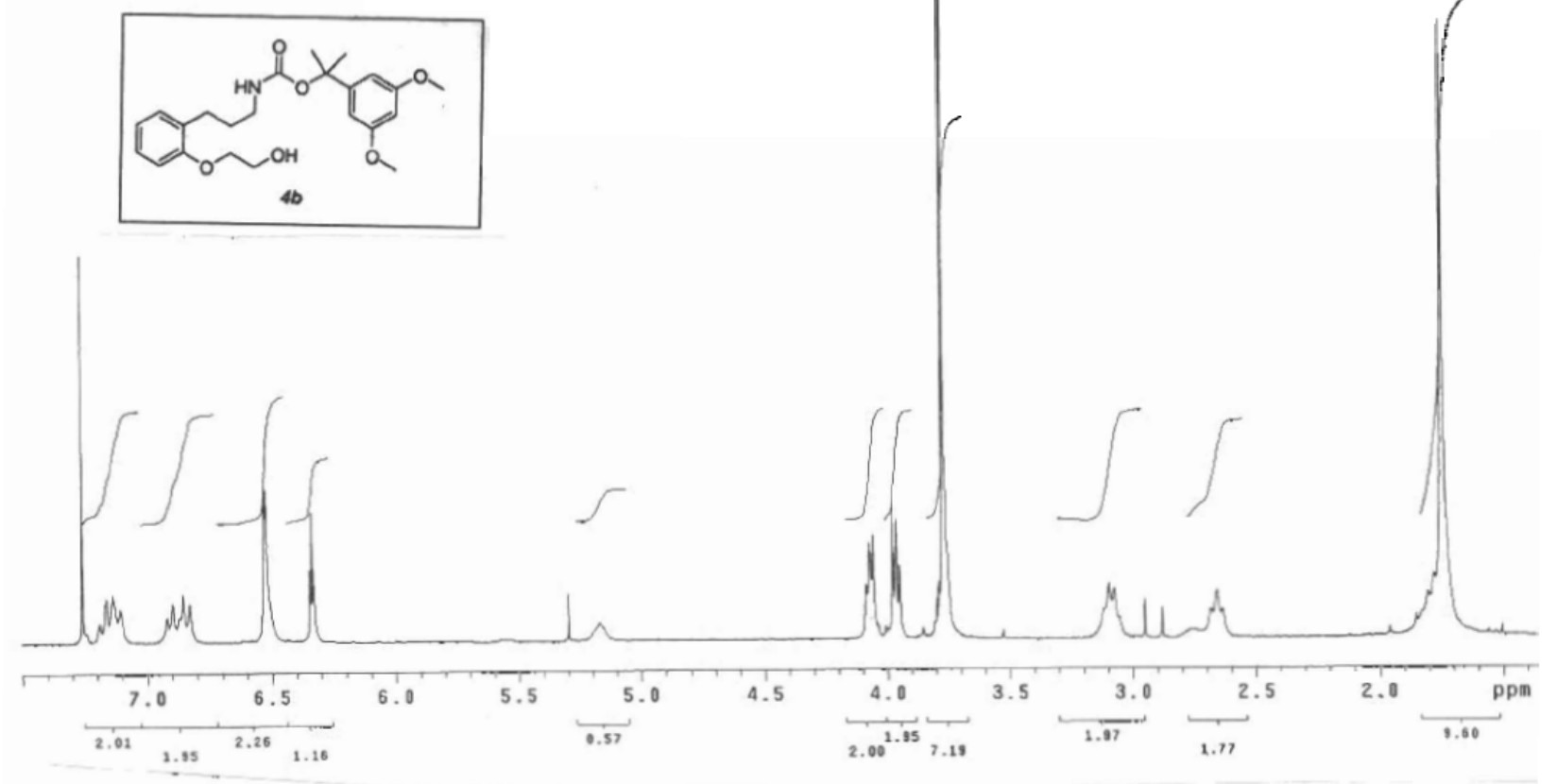

119

Archlve directory: /export/home/1uc/viorsys/data Fllet CaRBoN

Pulse Sequence: s2pur
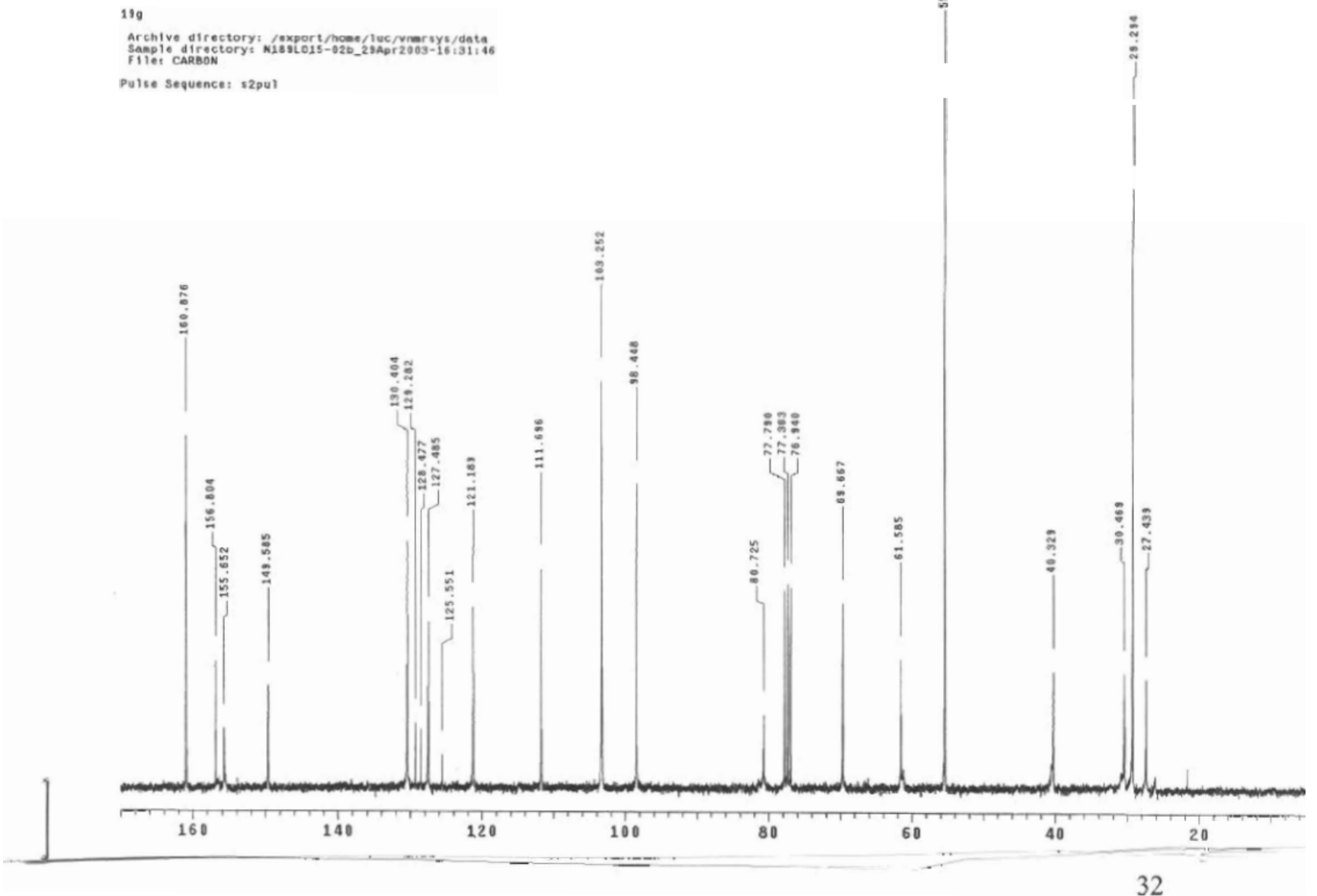

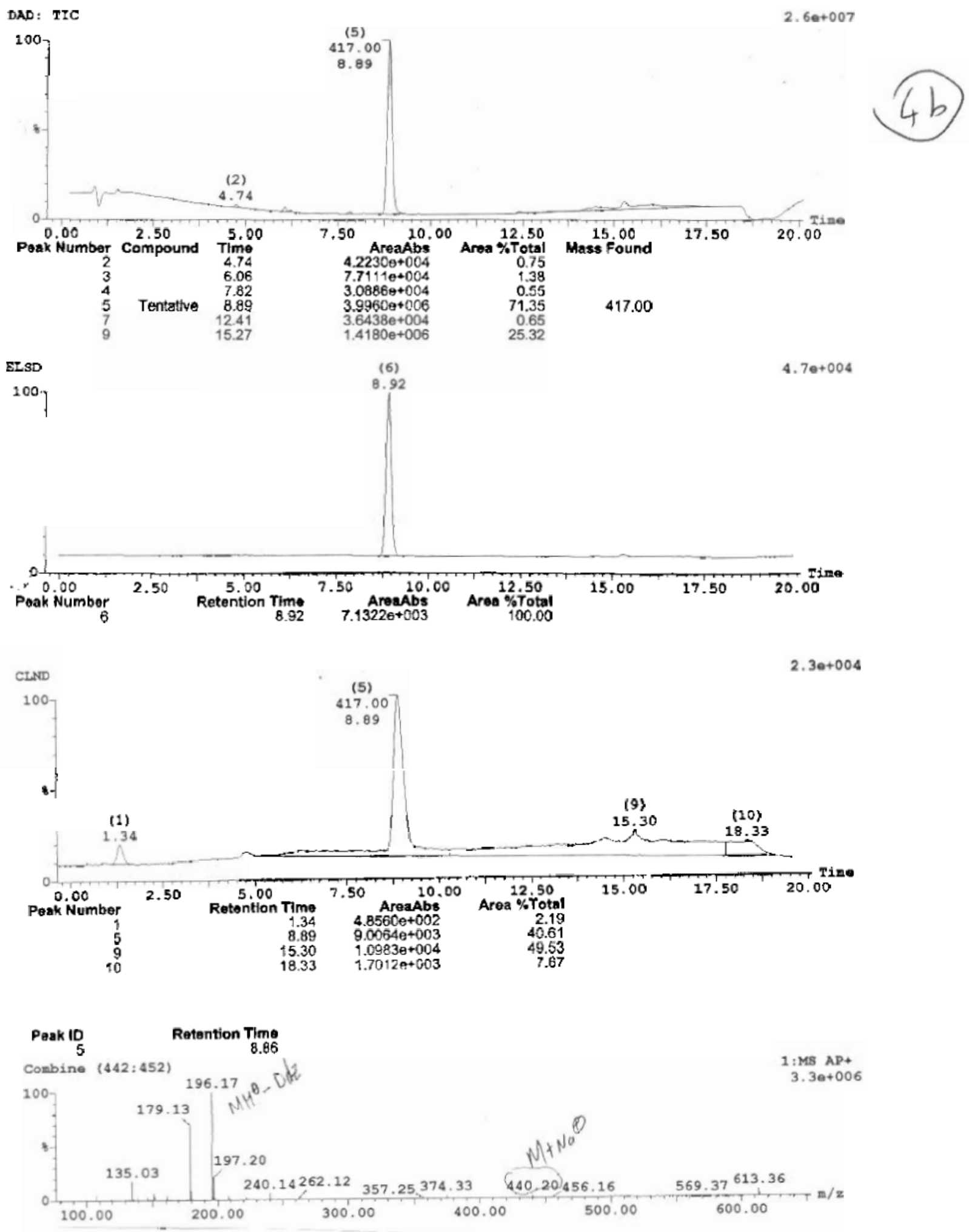


\section{c. Tether $4 c$}

$4 c$
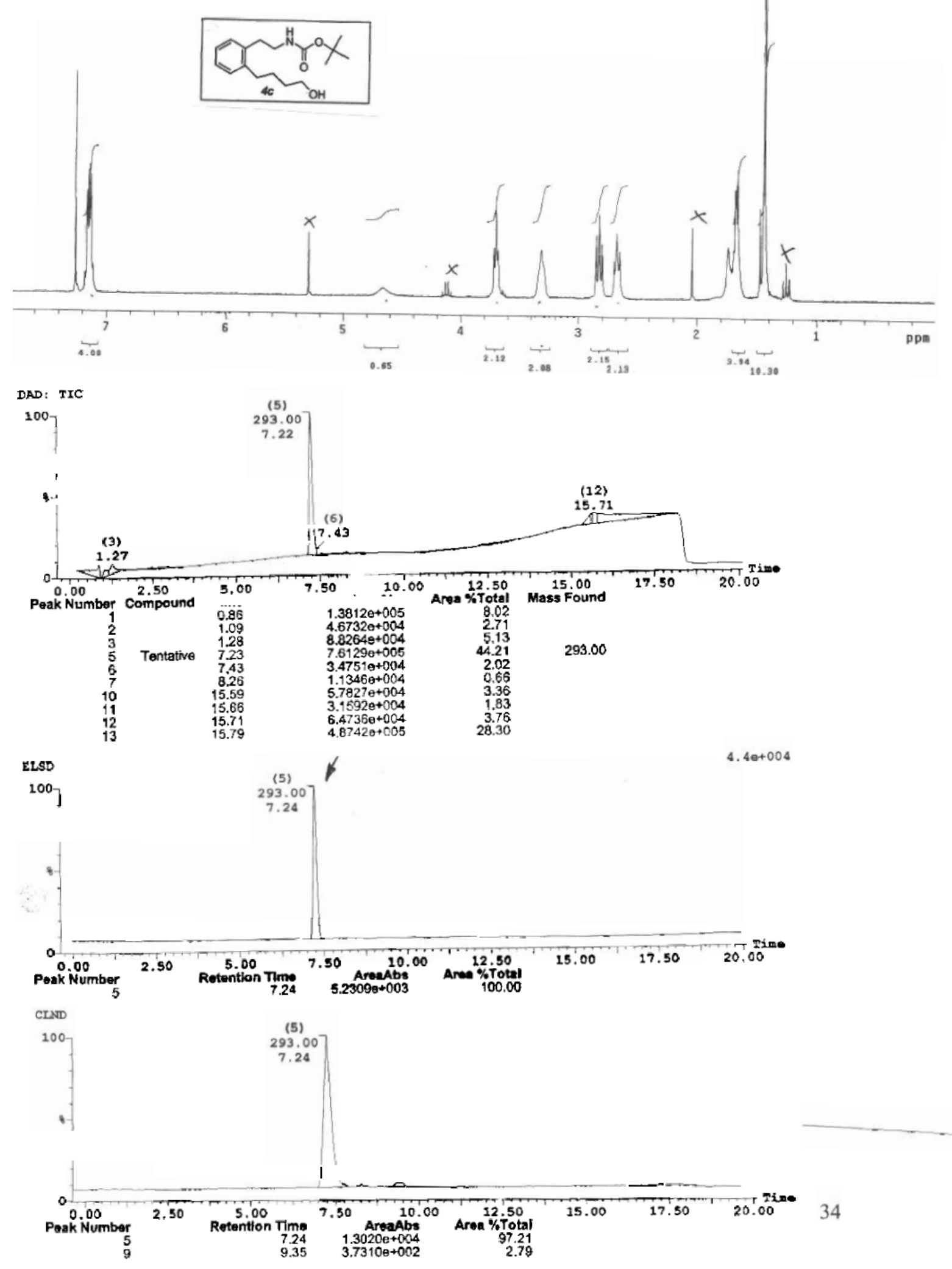


\section{d. Tether 4d}

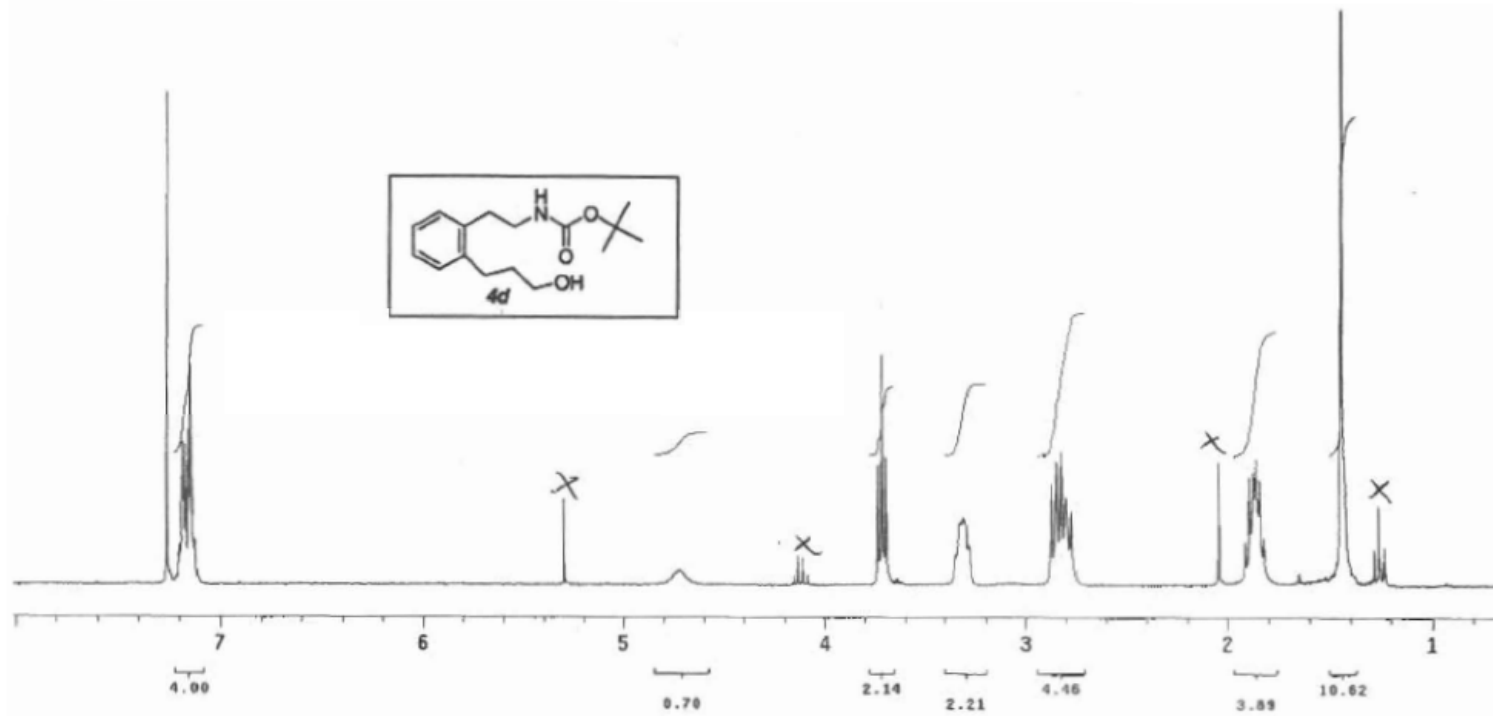

DAD: TIC
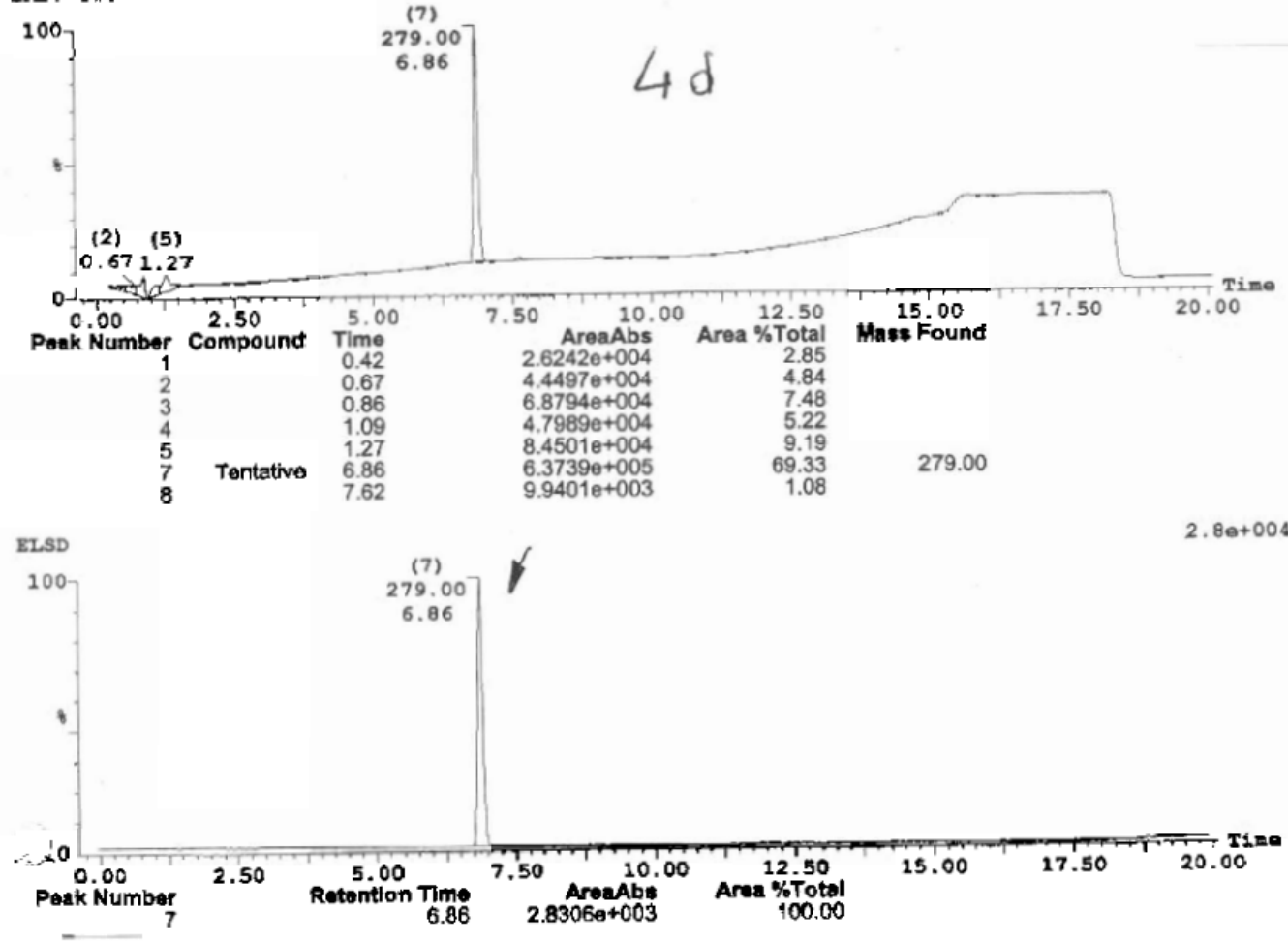

$6.862 .83060^{2} 003$

100.00

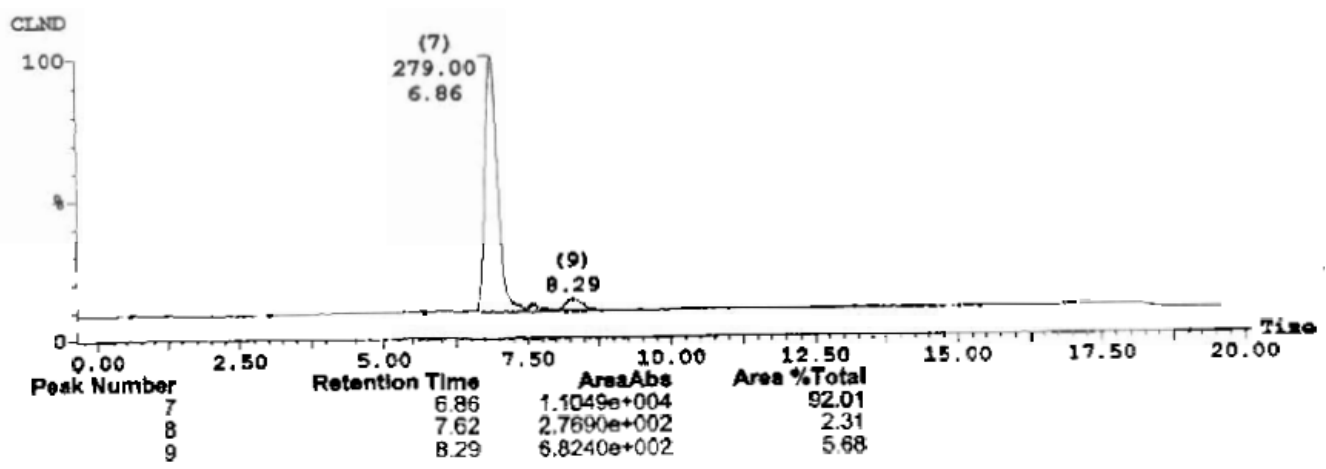


e. Tether $4 g$
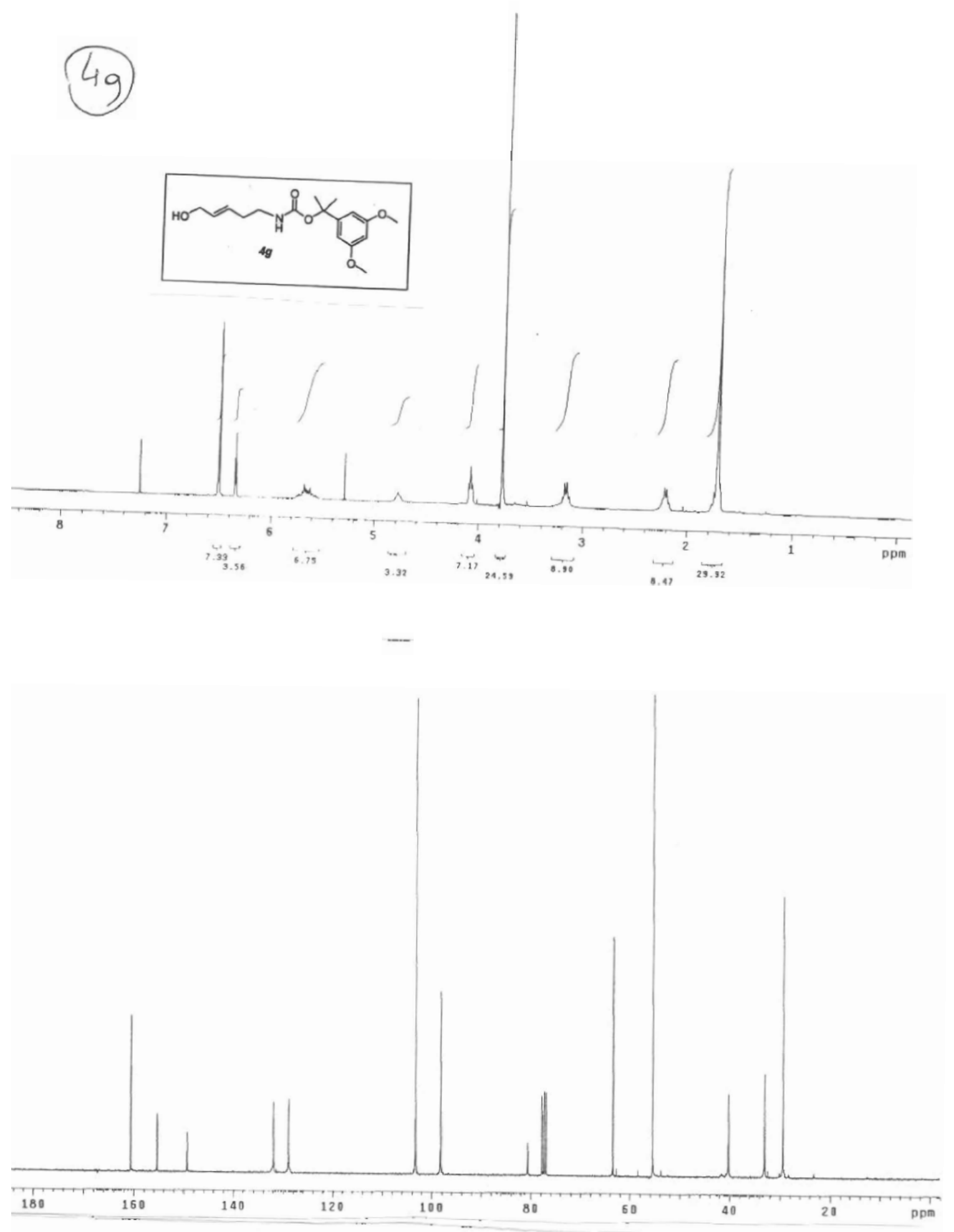


\section{f. Linker 7}

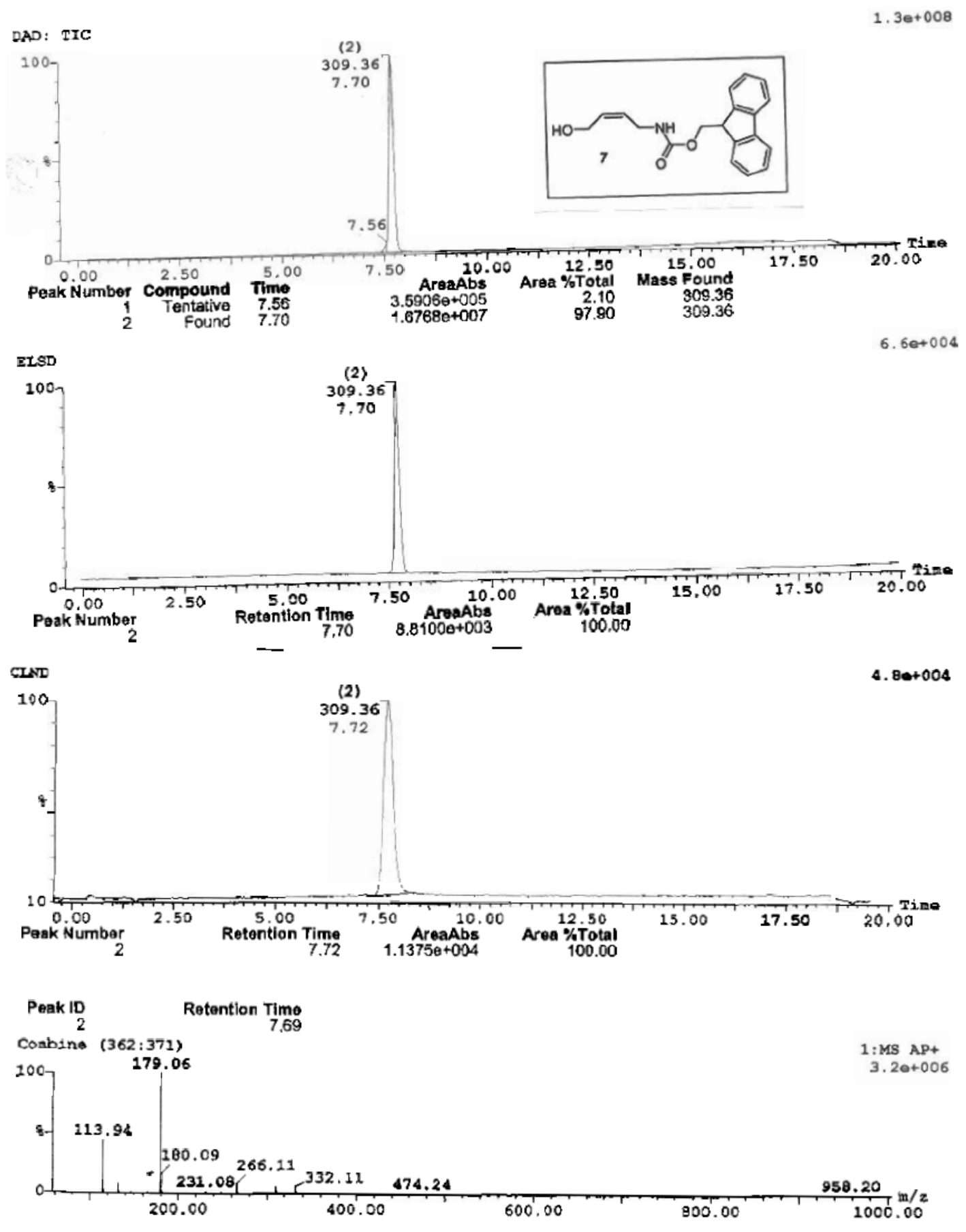



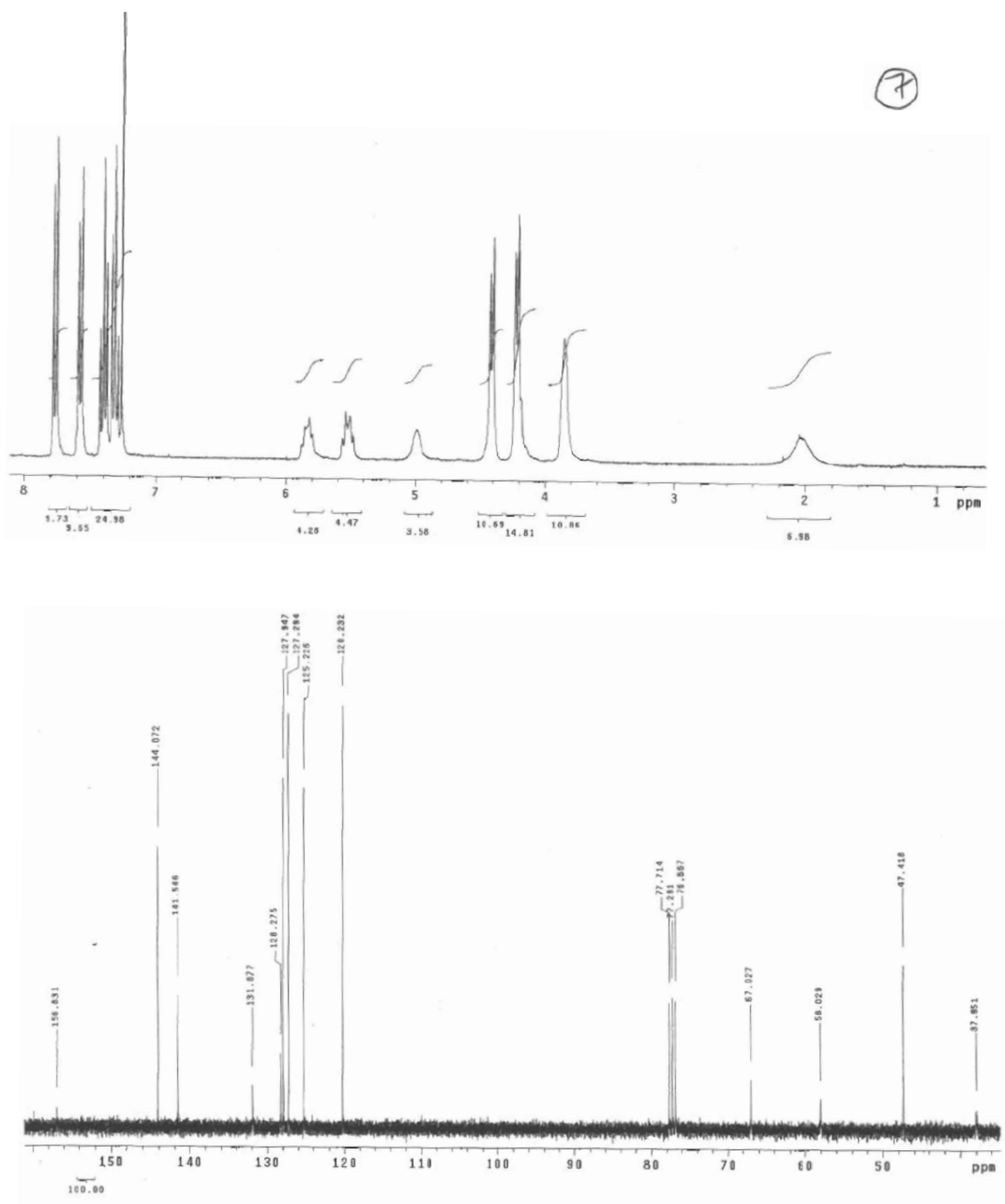


\section{Appendix 2. Chromatograms and MS spectra for final macrocycles}

a. Macrocycle 1
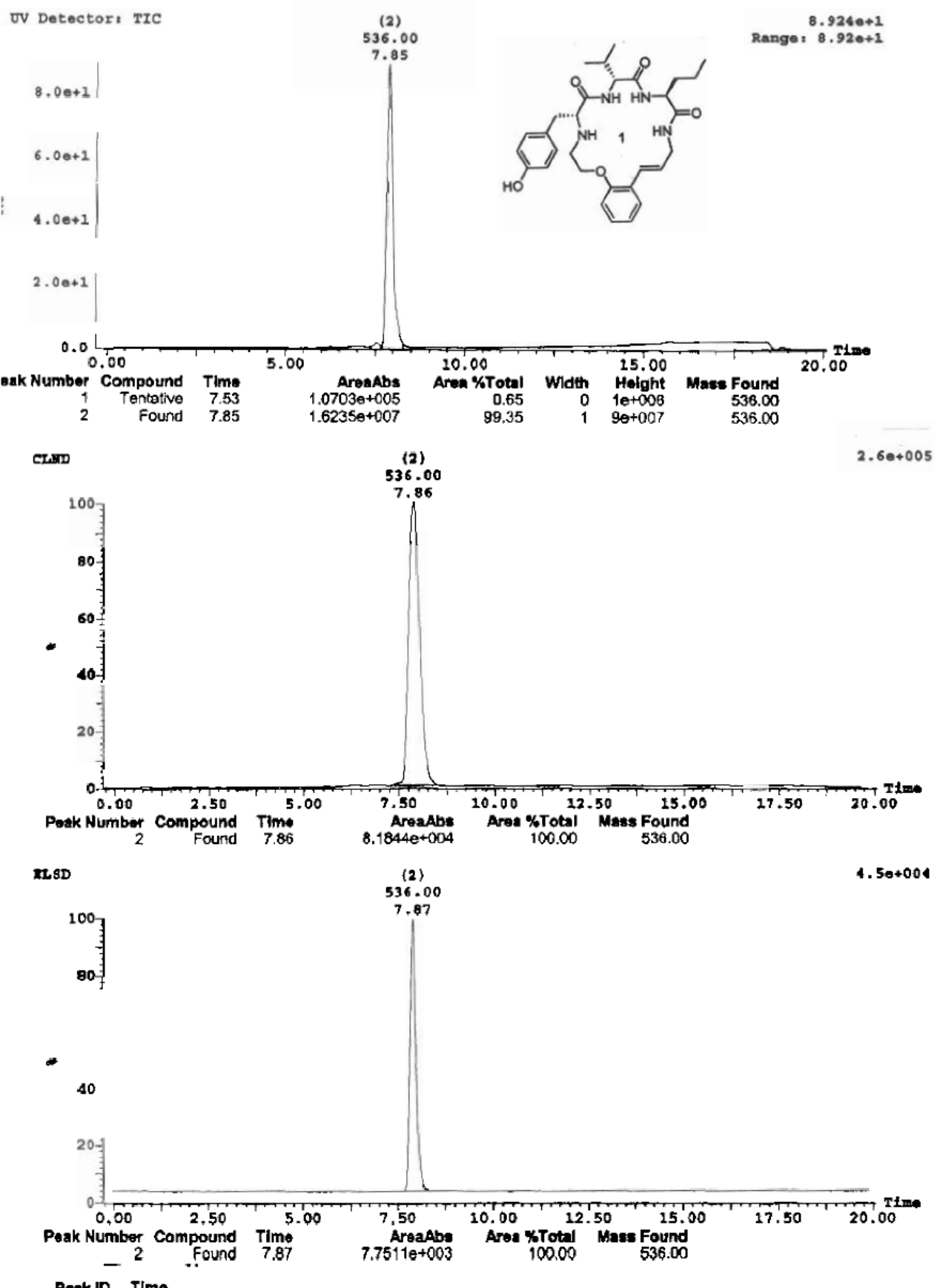

$\begin{array}{rr}\text { Peak ID Time } \\ 2 & 7.86\end{array}$

2. Combine $(301,309)$

$1: 103 \mathrm{NP} \cdot$

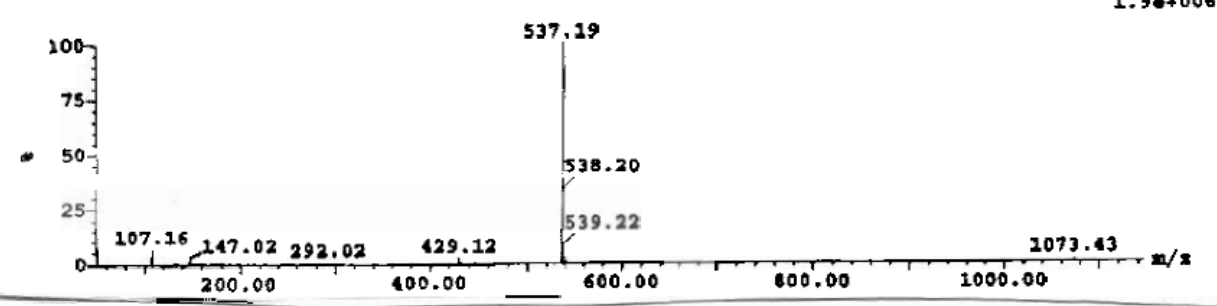




\section{b. Macrocycle 12a}

DAD: TIC
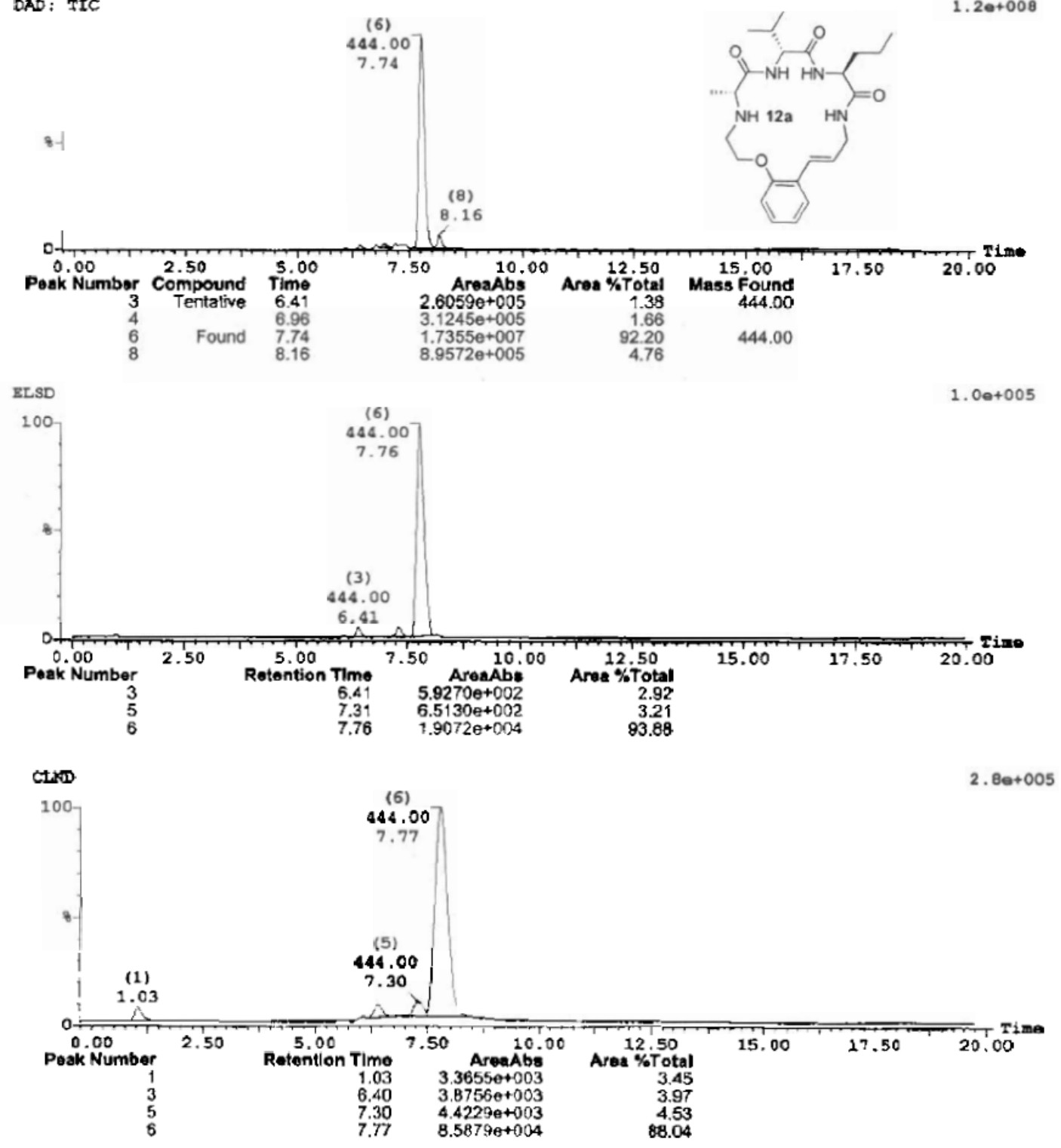

\section{Peak ID $\quad$ Retention Time}

Combine $(280: 286-(268: 271+308: 311)) \quad 1: M S$ AP+

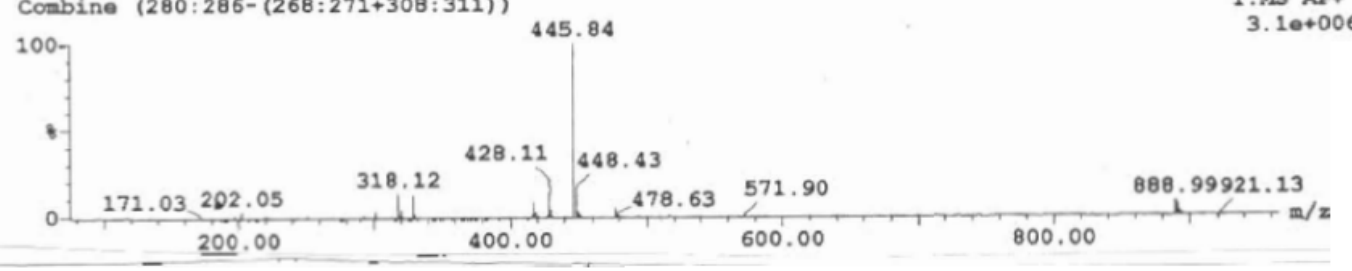




\section{c. Macrocycle 12b}

2. UV Dutactor: IIC

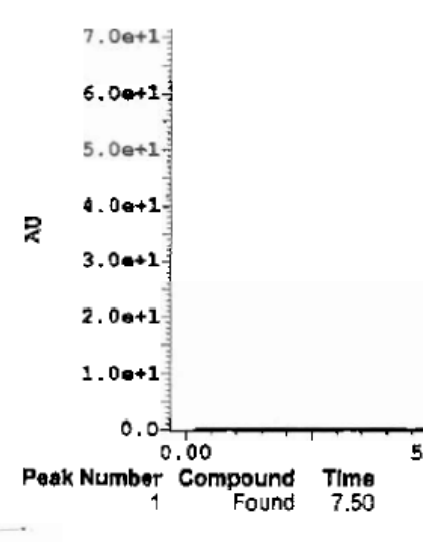

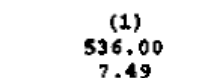

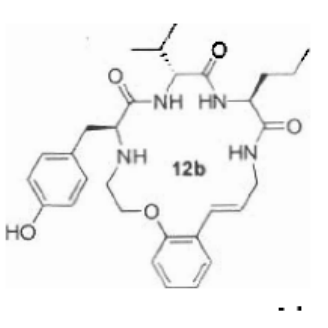

Range: $7.148 \theta+1$
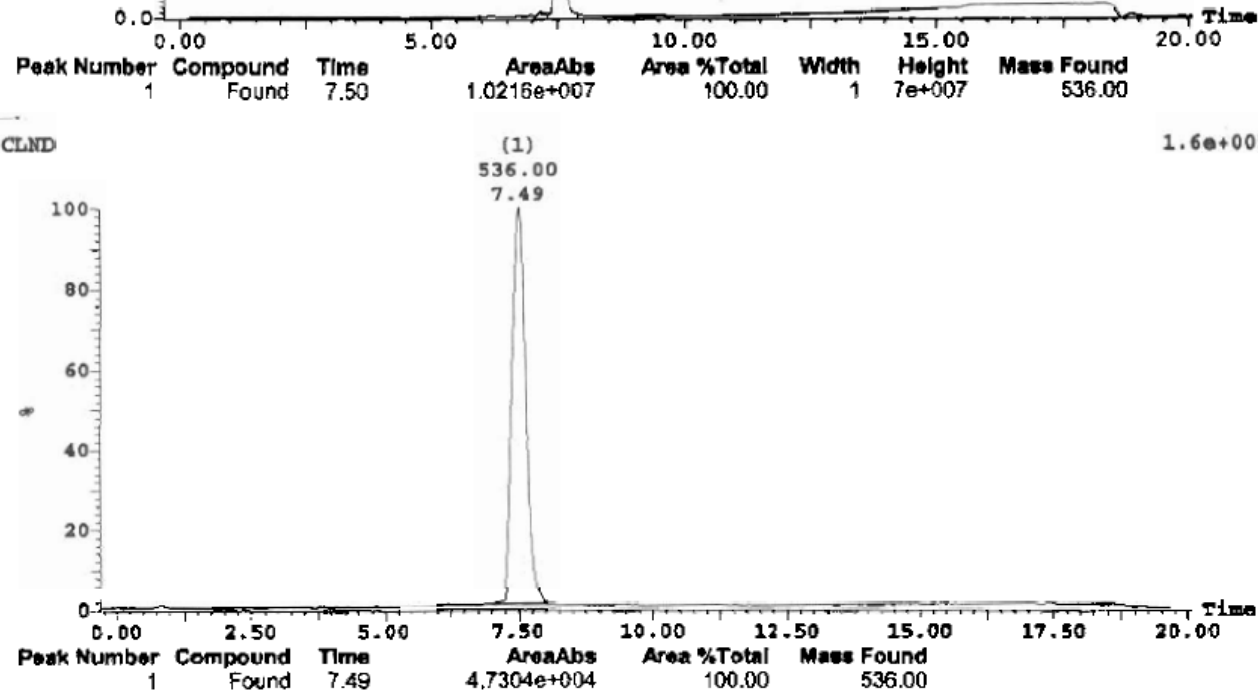

AreaAbs

$1.6 e+005$

6.00

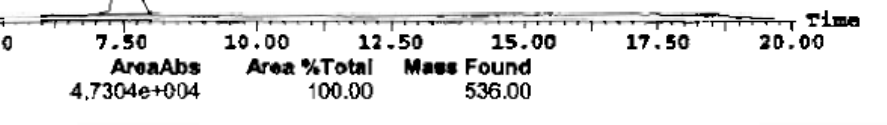

MLSD

(1)
536.00

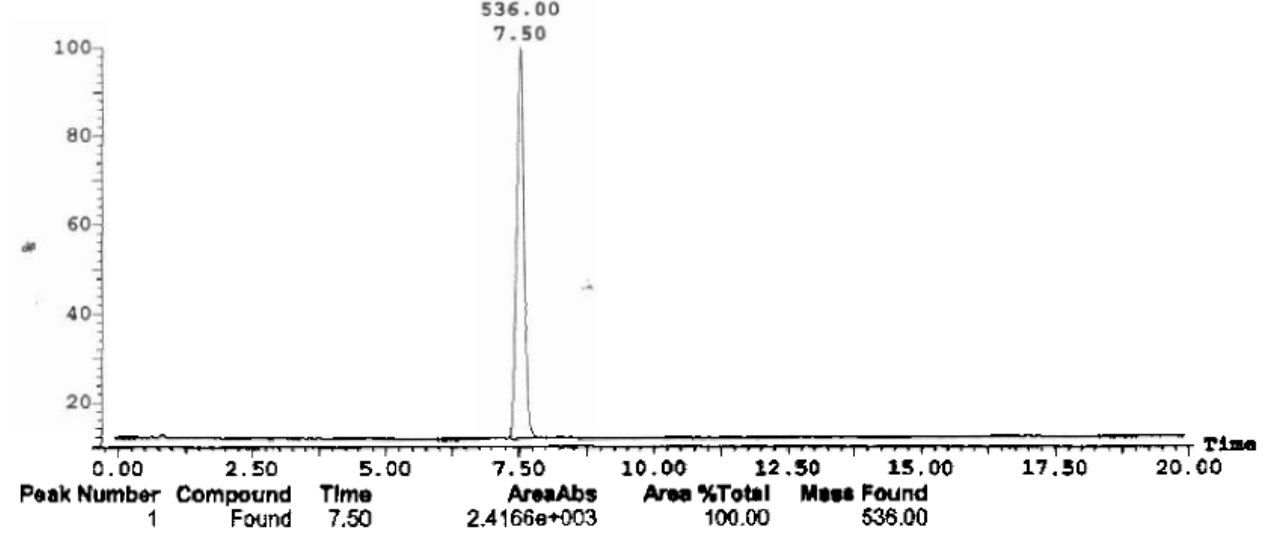

Peak ID Time

1: combine $(283,290)$

$1, \mathrm{KSSAP+}$

1. $3 e+006$

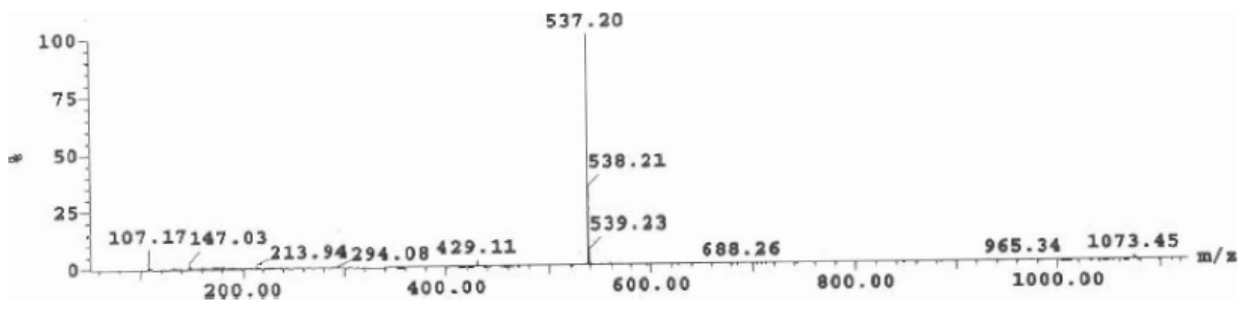




\section{Macrocycle 12d}

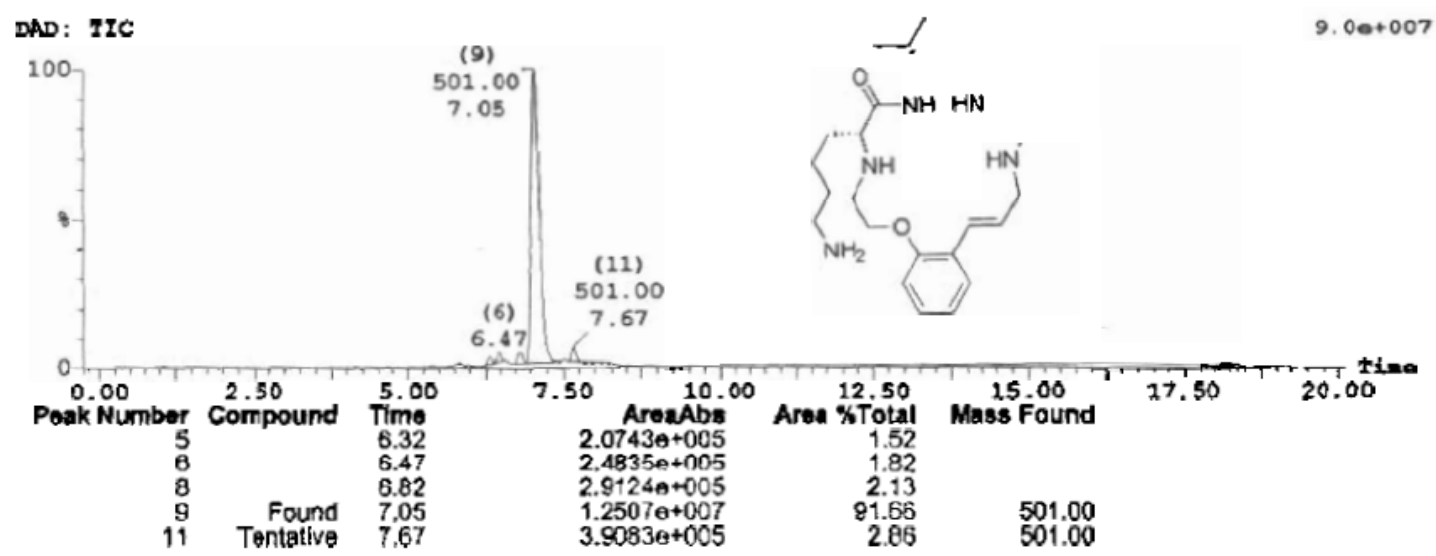

RZSD
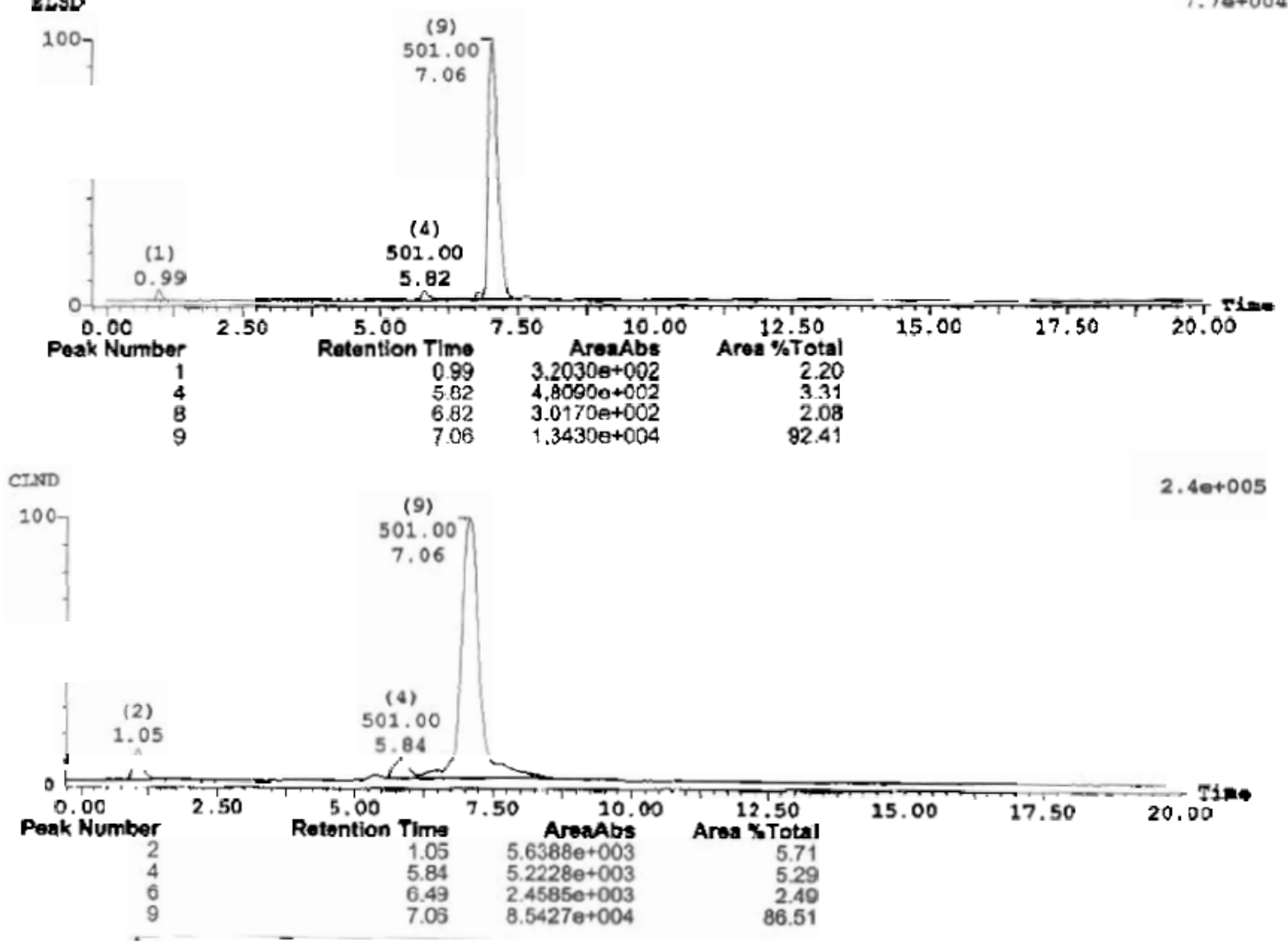

Peak ID Retention Time

Combin॰ (310:316-(290:294+369:372)) $1:$ MS AP+

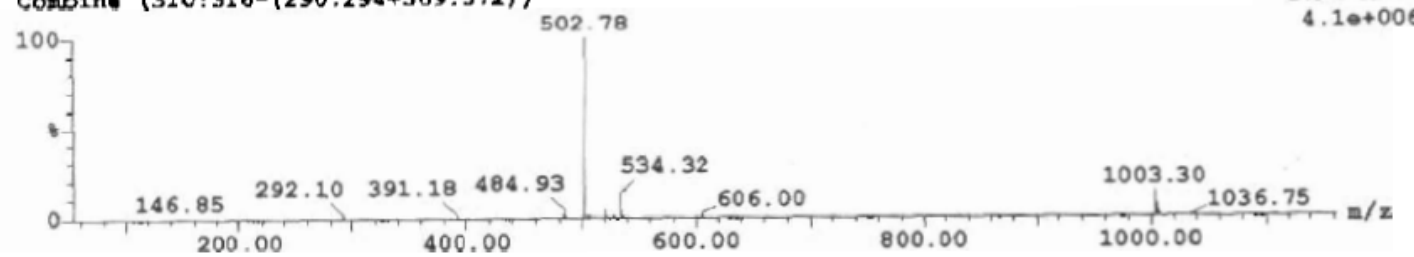


d. Macrocycle $12 \mathrm{f}$

(5)
520.00

$4.4720+1$

9.30

Range: $4.470+1$

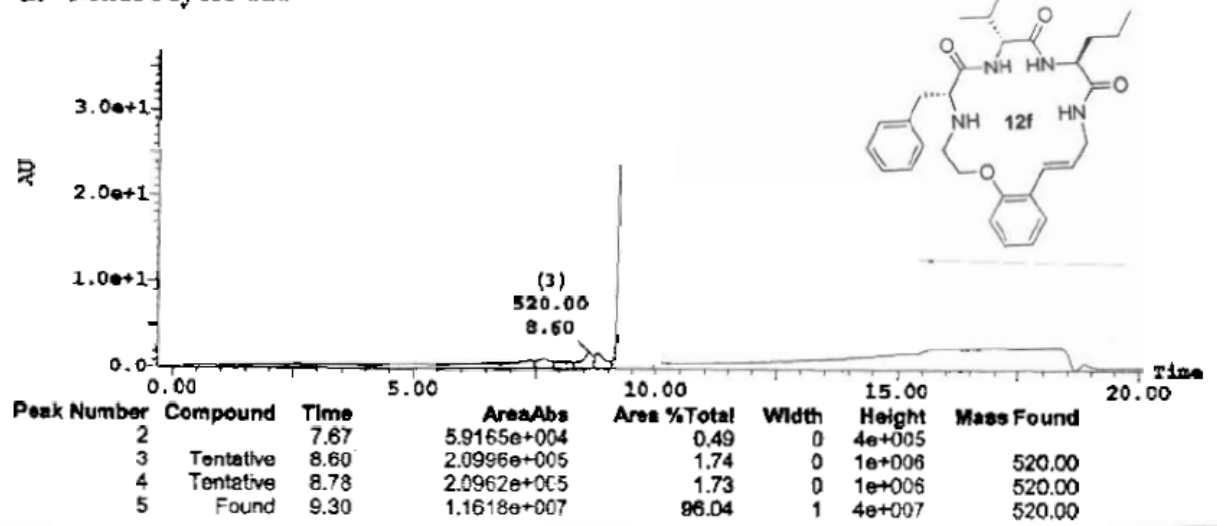

Cxam

(5)
520.00

$1.8 e+\overline{005}$

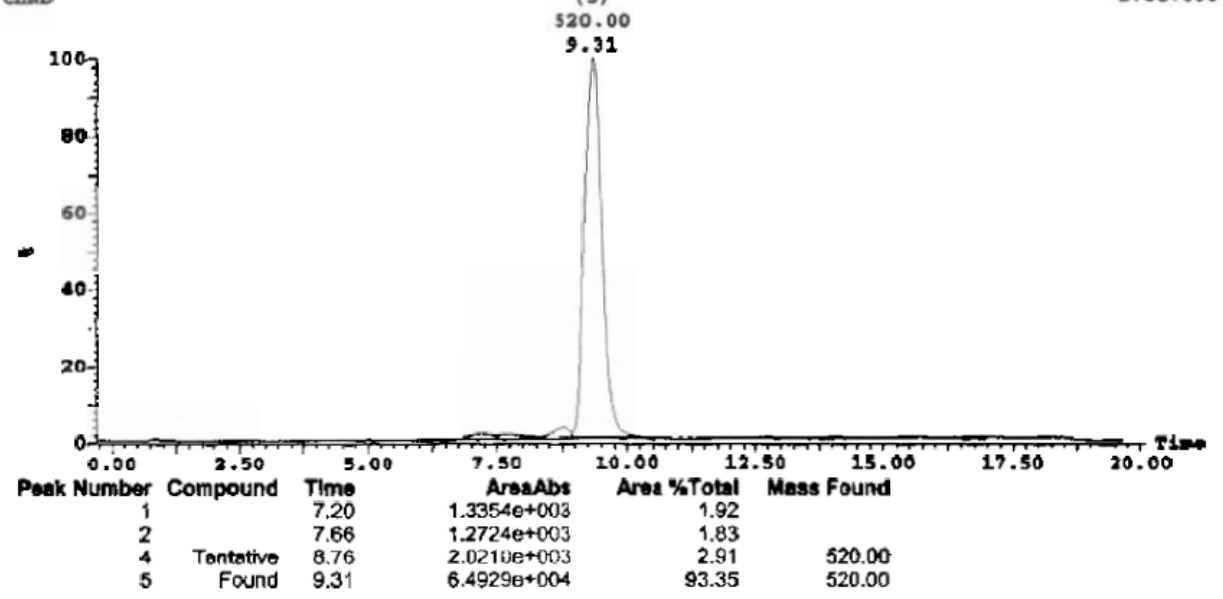

ILSD
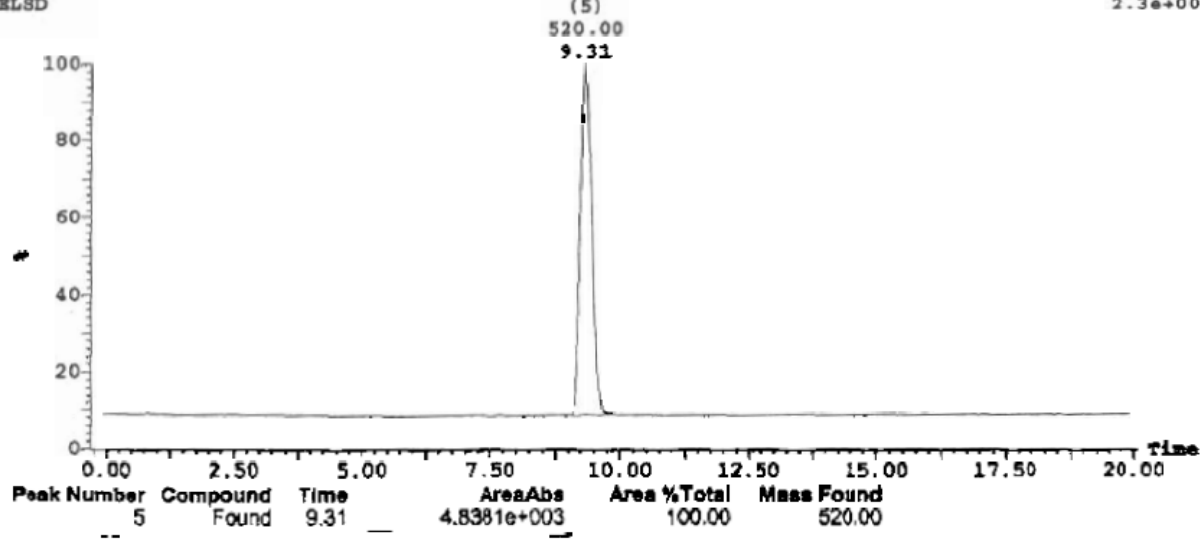

Peak ID $\begin{array}{rr}\text { Time } \\ \mathbf{9}\end{array}$

5. Combine (361,369)

$1 . \mathrm{KSBN+}$

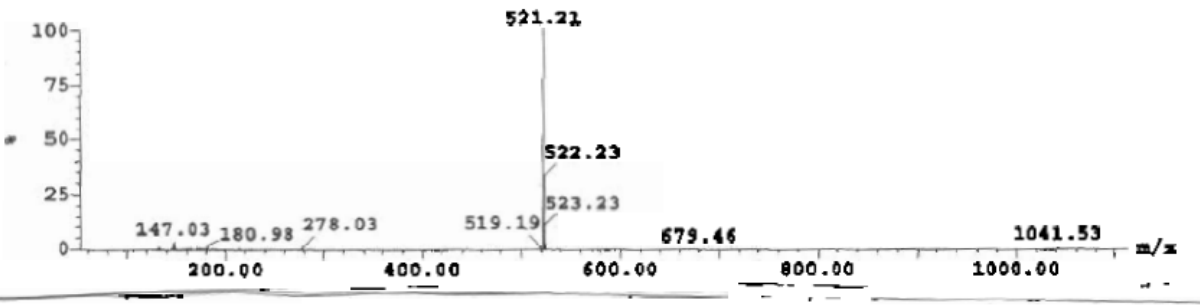




\section{e. Macrocycle 12g}
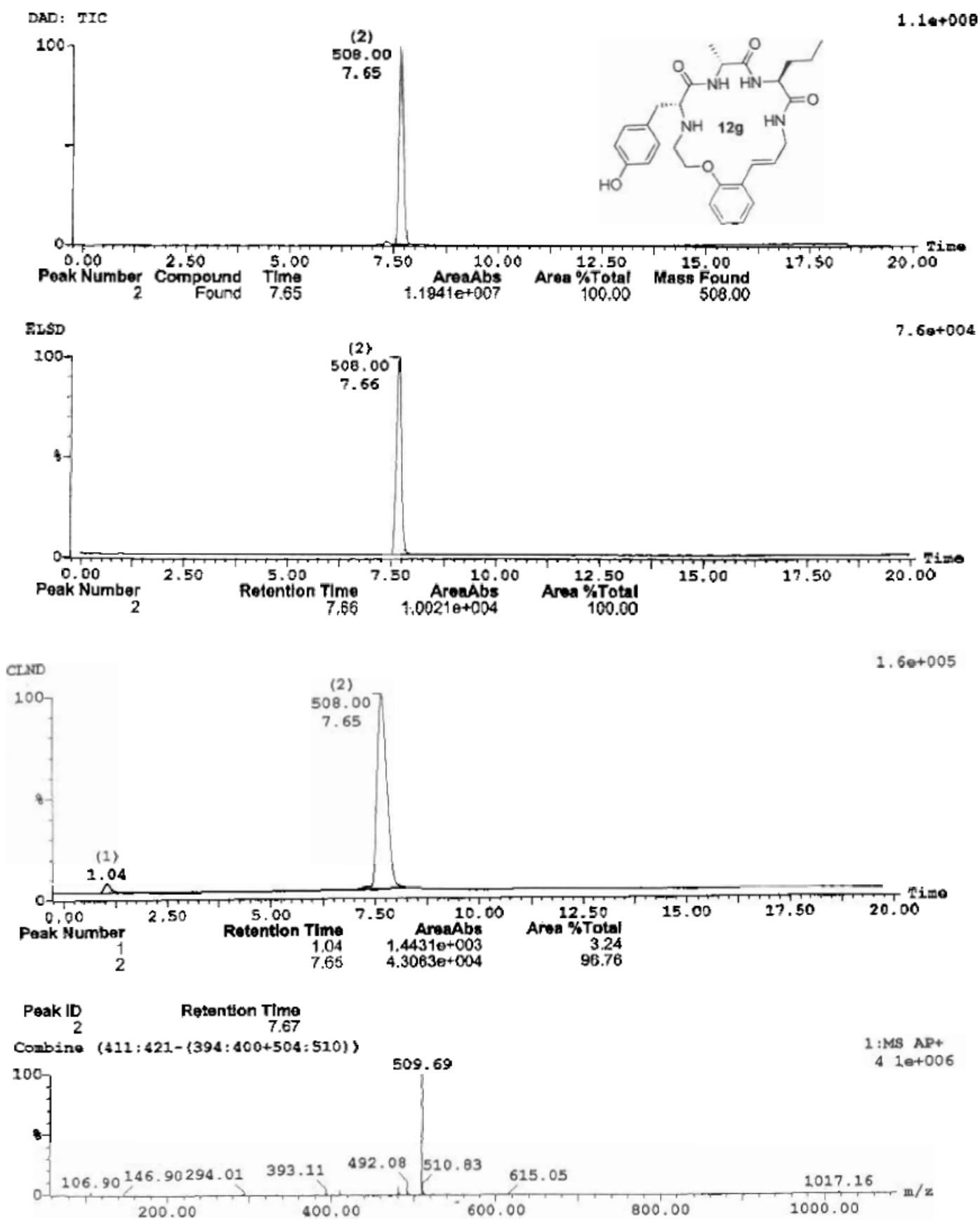


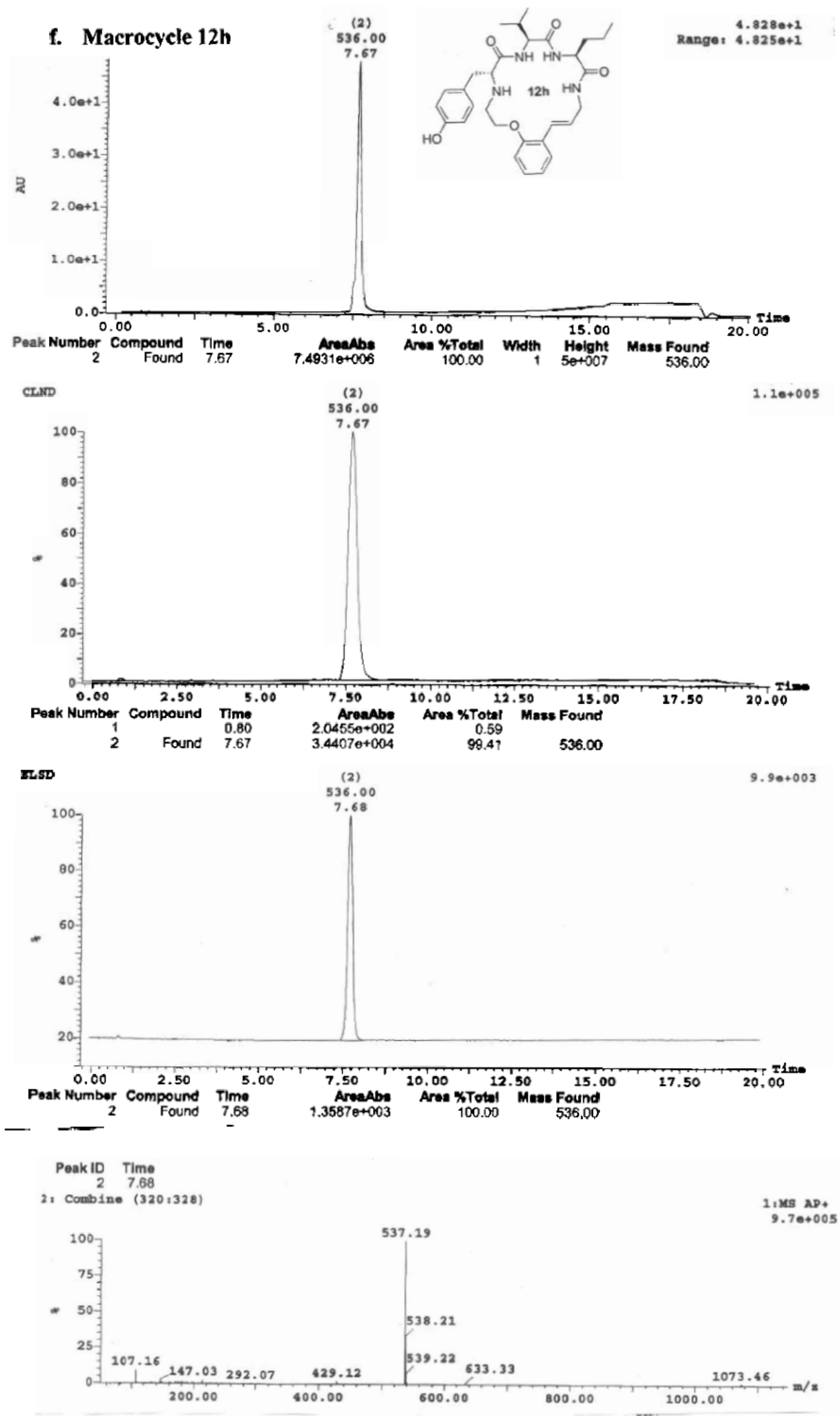




\section{g. Macrocycle 12i}
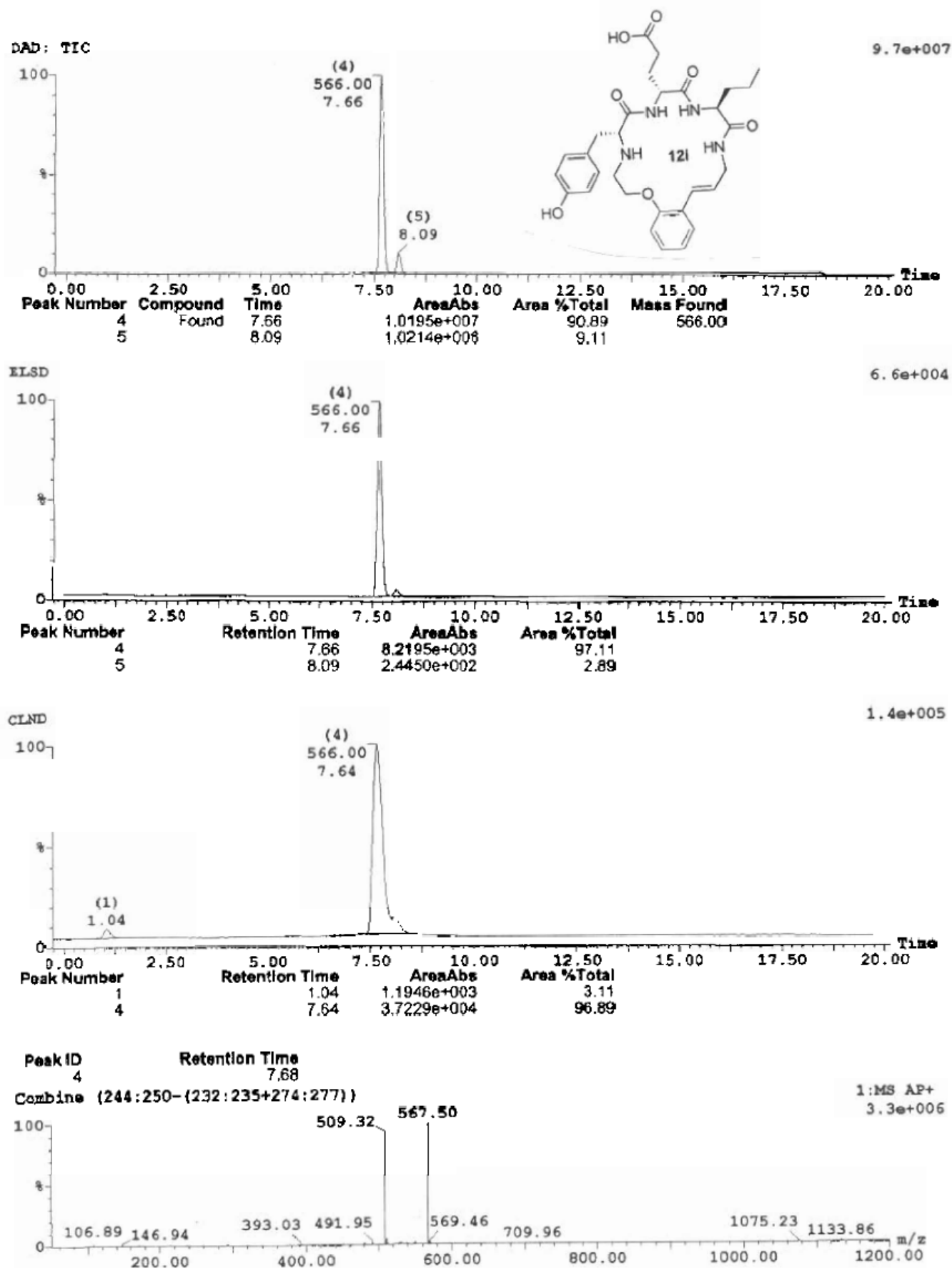


\section{h. Macrocycle 12j}
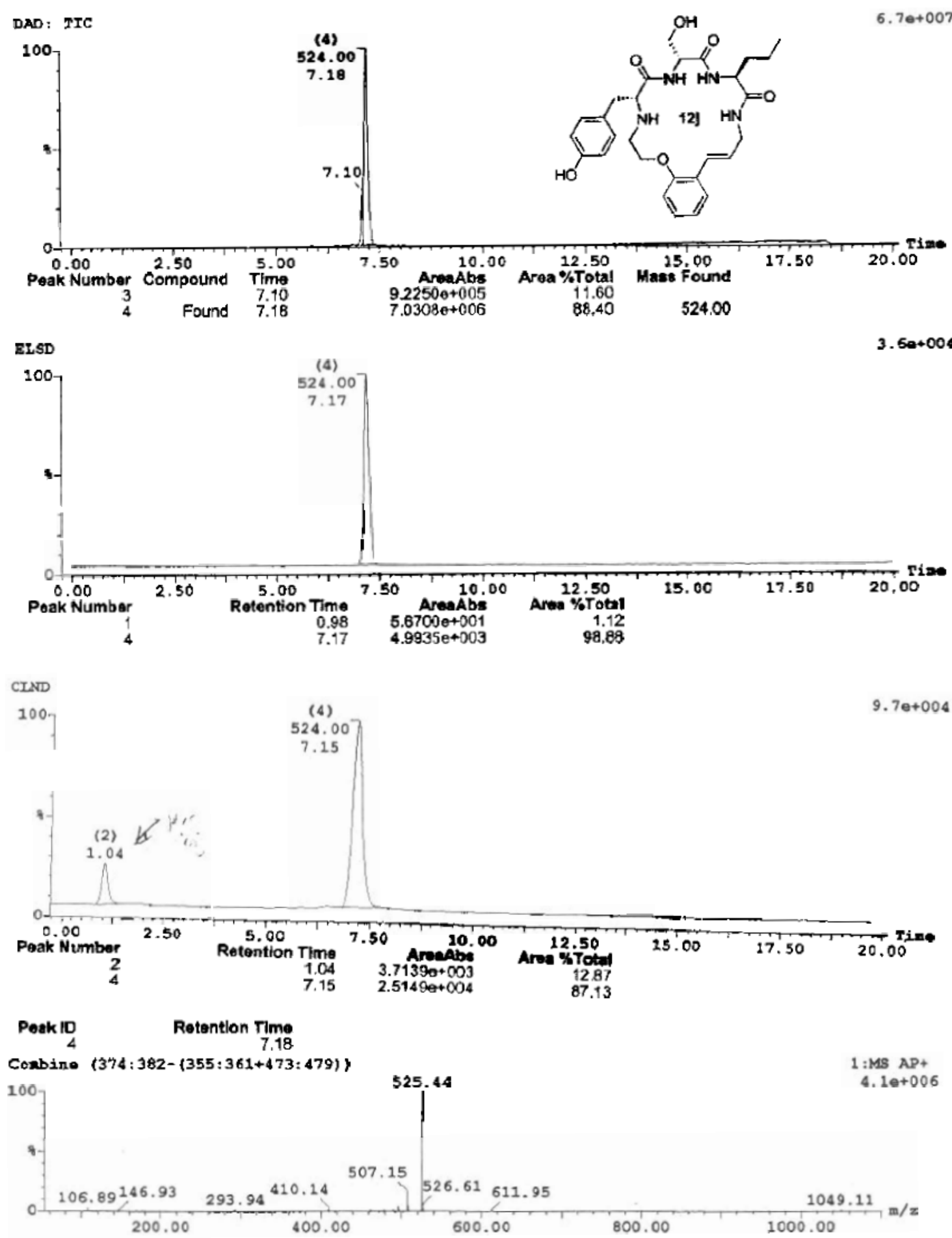


\section{i. Macrocycle 12k}
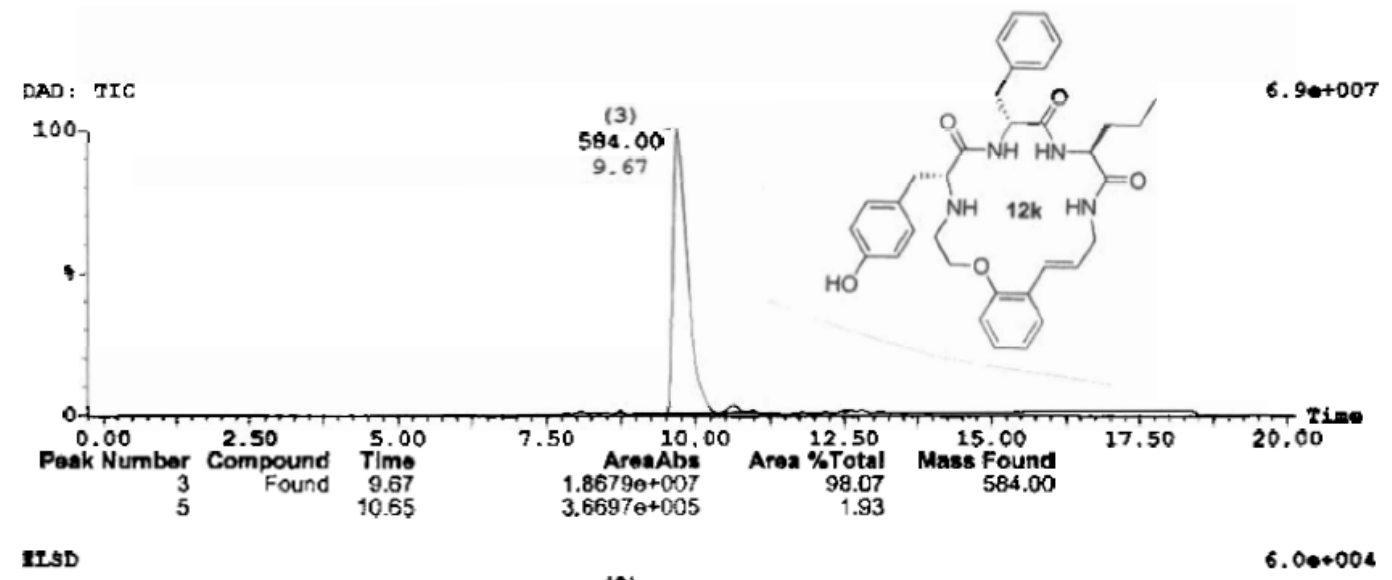

10

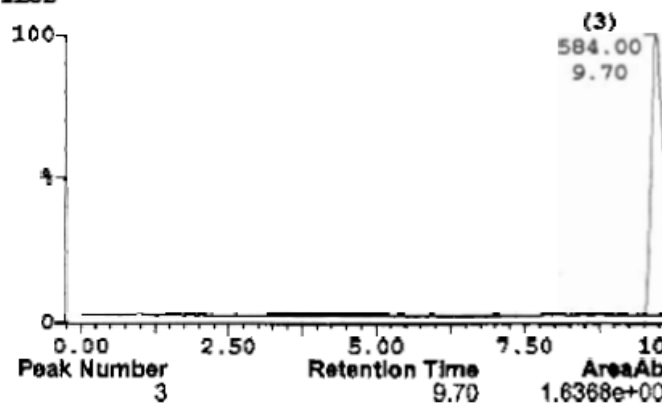

(3)

$6.00+004$
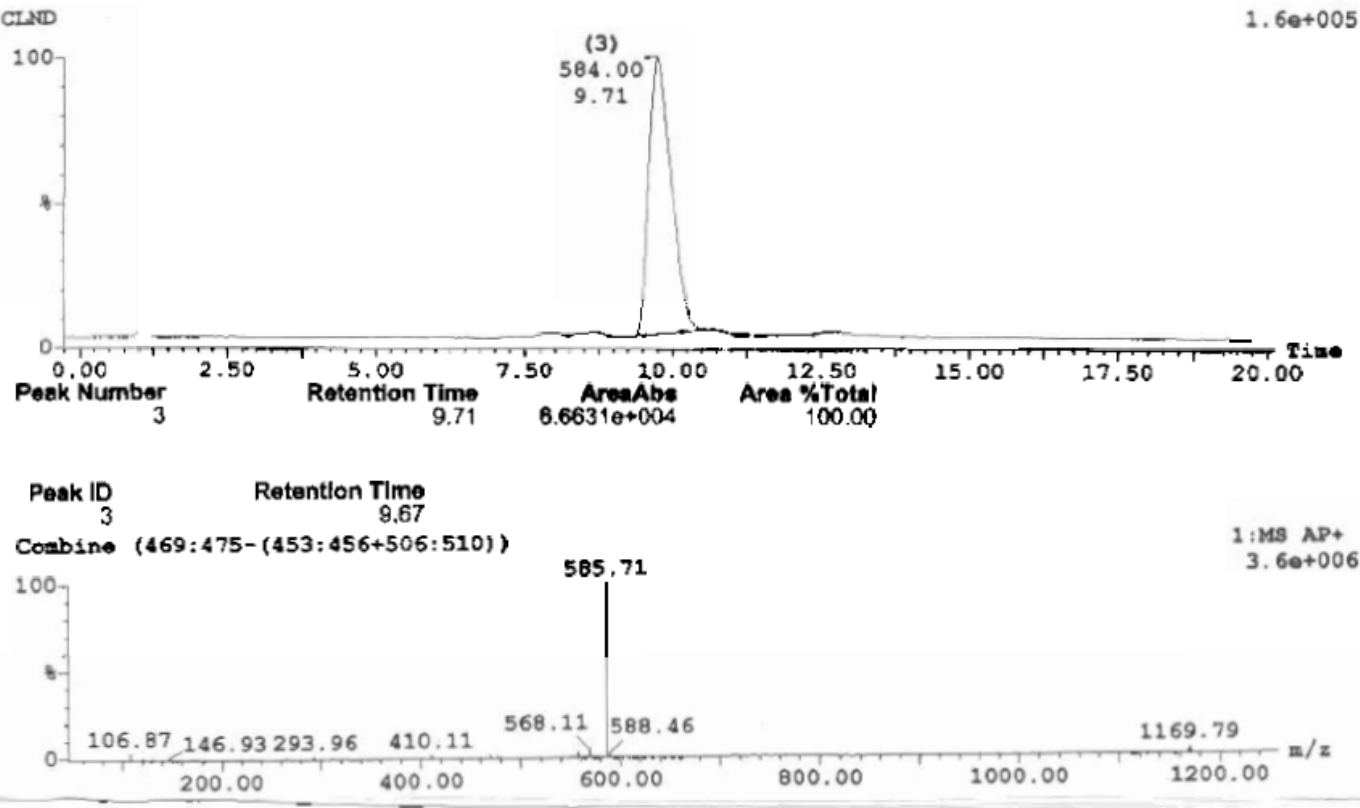


\section{j. Macrocycle $12 \mathrm{~m}$}

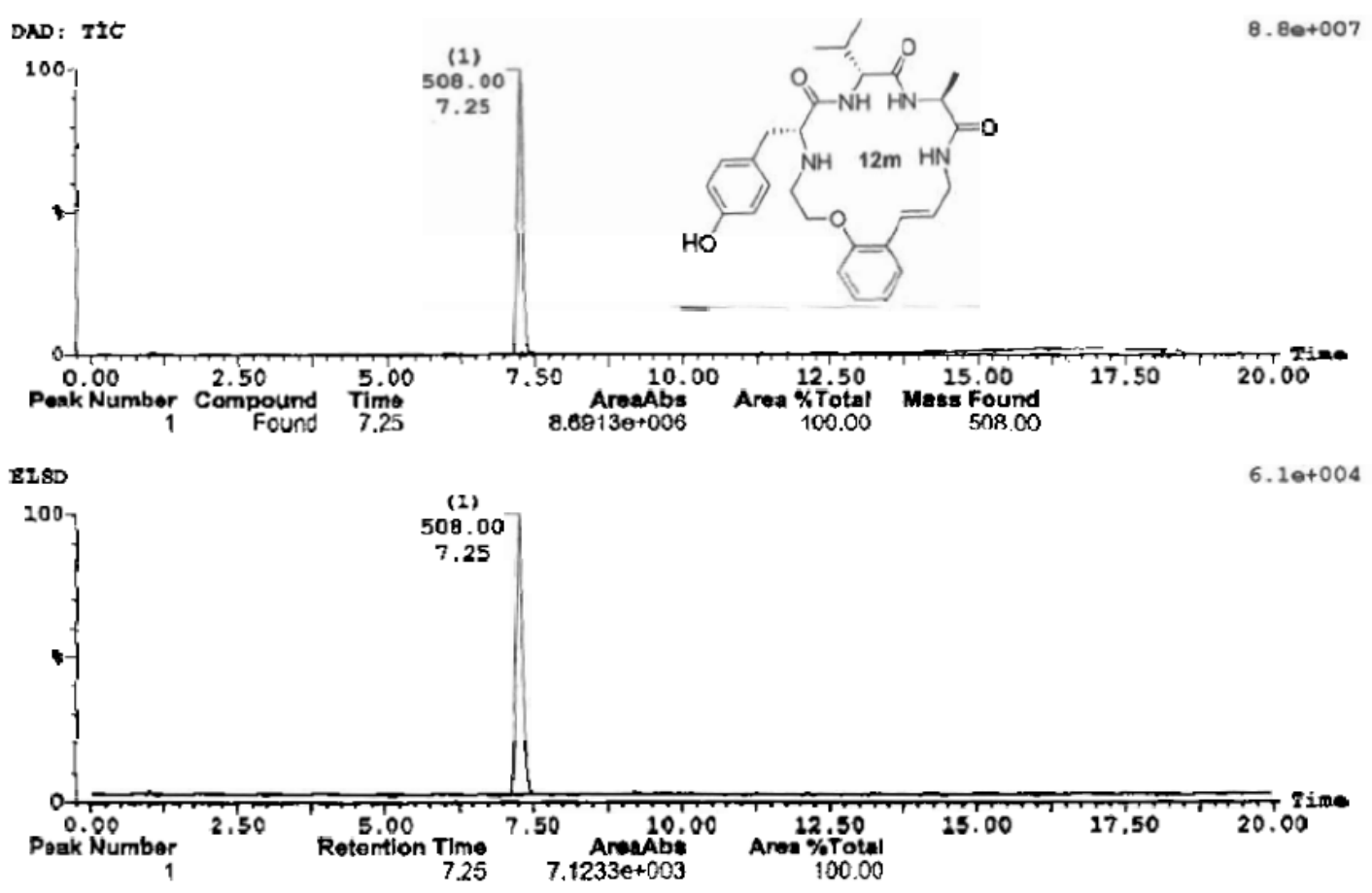

$\begin{array}{lll}\text { Openlynx Report - } & \text { Stucture ID:C-(D)Tyr-(D)Val-Ala-018 } & \text { File Name:NP000234-B1-Z-MS1-1 } \\ \text { Position:1:35 } & \text { Time:"7:07:40 } & \text { Description:Grod_B4 } \\ \text { Daks d'injection:28-Nov-2002 } & & \\ \text { Printed: Fri Nov } 29 \text { 08:51:34 2002 } & & \end{array}$

Printed: Fri Nov 29 08:51:34 2002

Sample Report (continued):

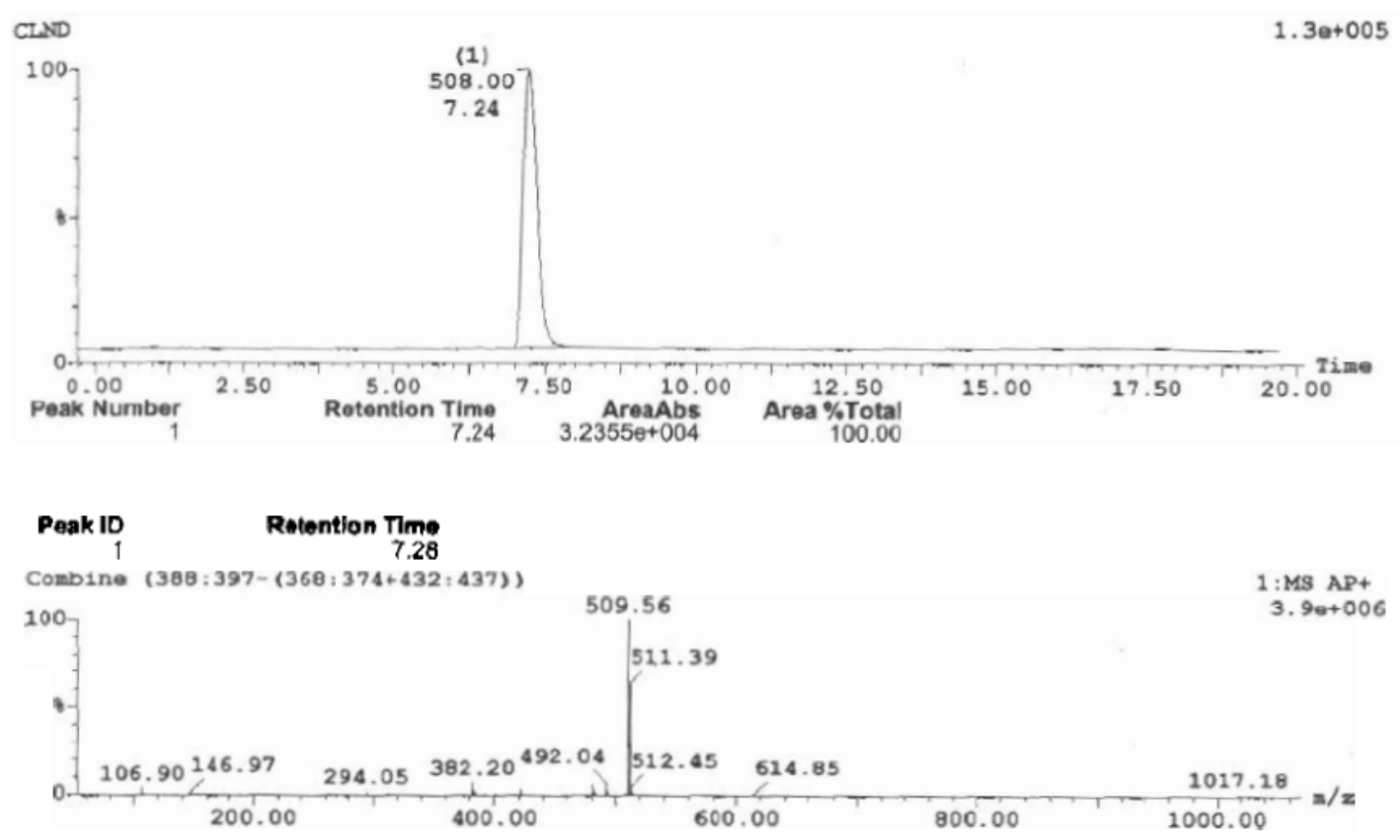




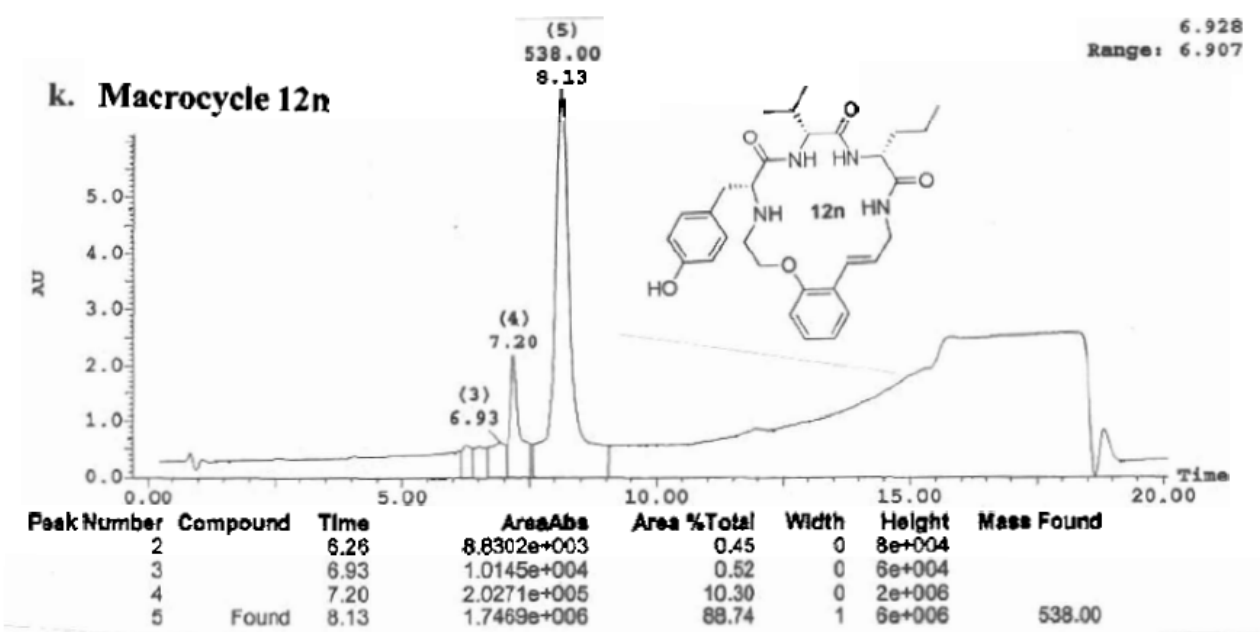

CIID

(5)
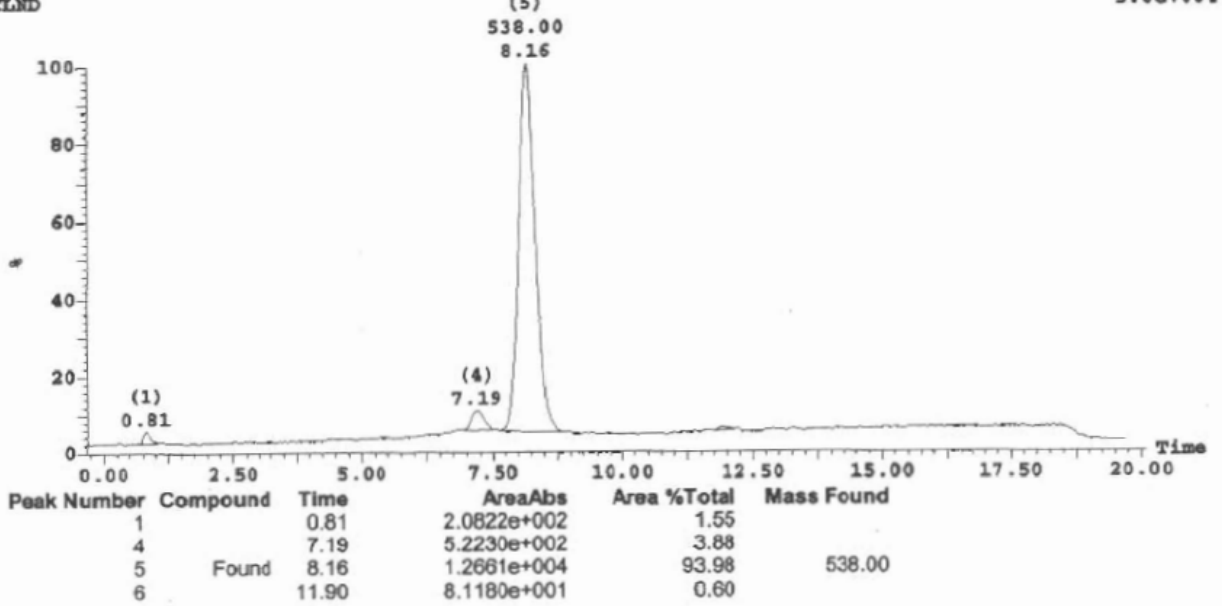

3L8D

(5)
538.00

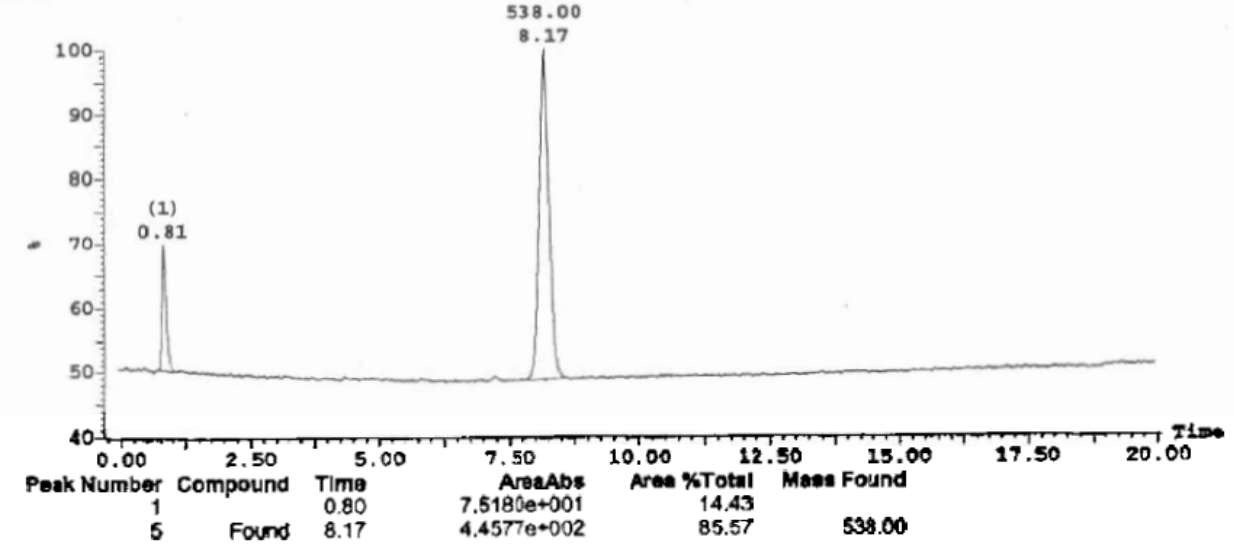

4. $06+003$

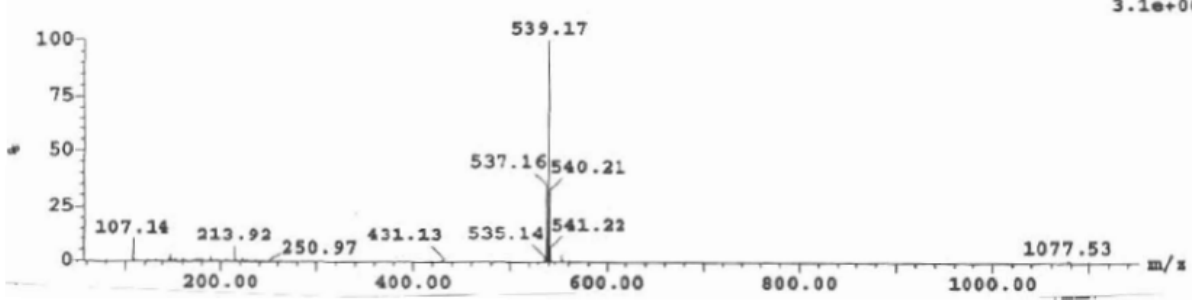




\section{Macrocycle 12p}
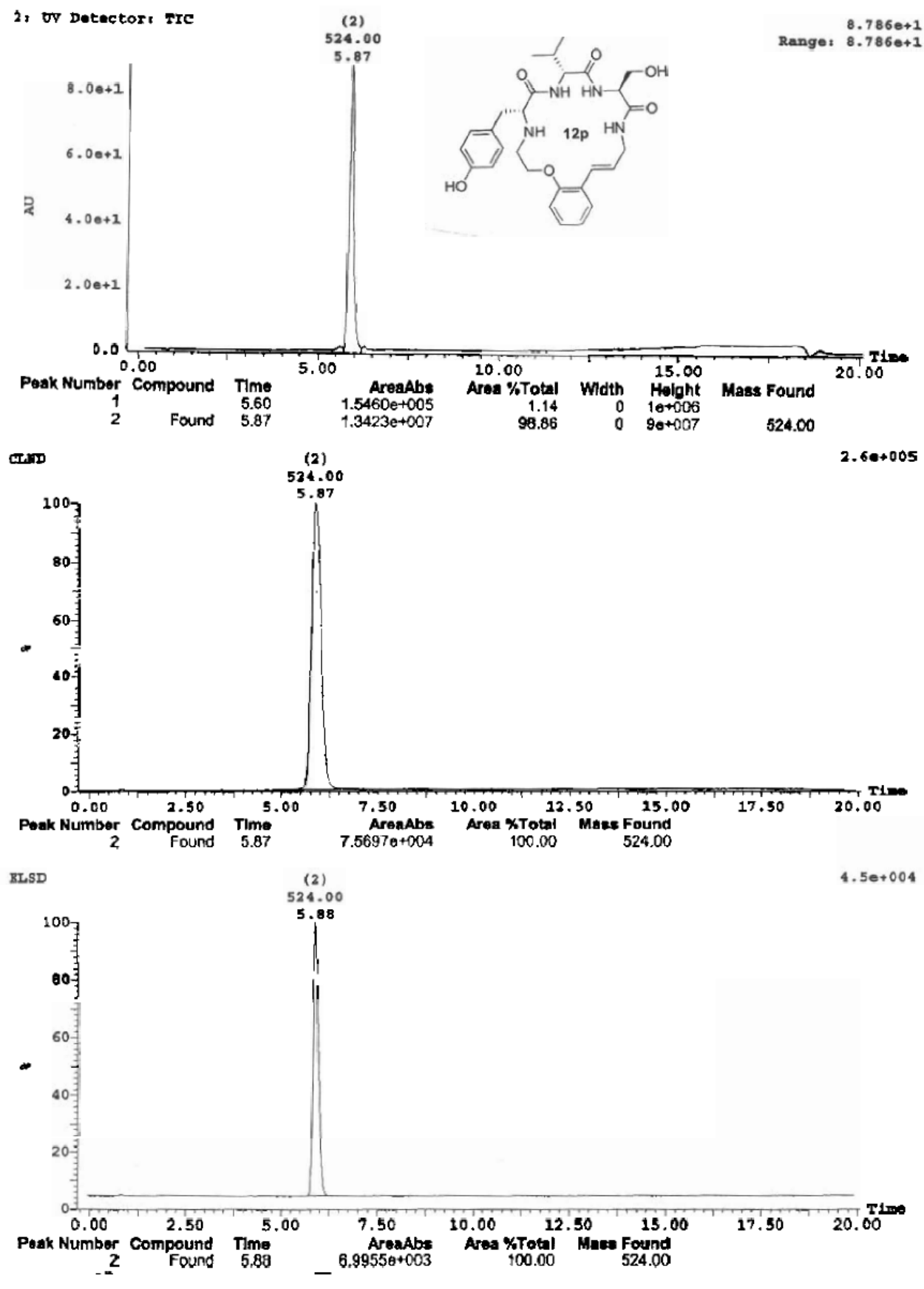

$\begin{array}{rr}\text { Peak ID } & \text { Time } \\ 2 & 5.88\end{array}$

25 Combine $(217,224)$

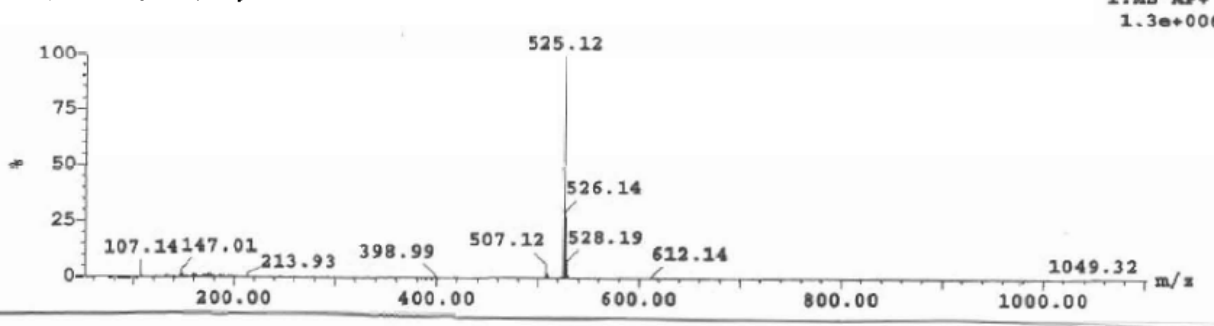



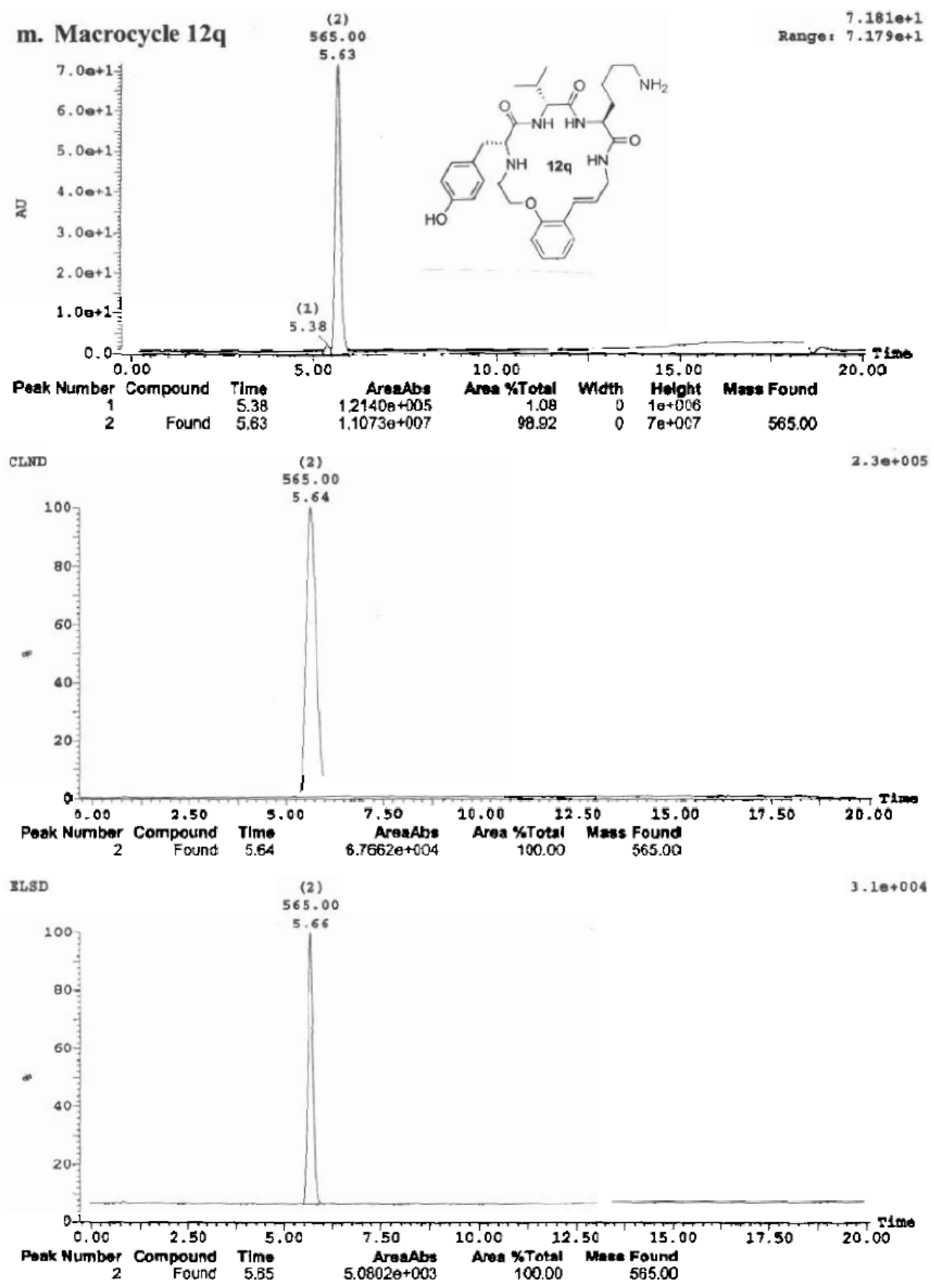

$$
\begin{array}{rr}
\text { Poak ID } & \text { Timo } \\
2 & 5.64
\end{array}
$$

2. Combine $(224: 232)$

$1, M S$ APt

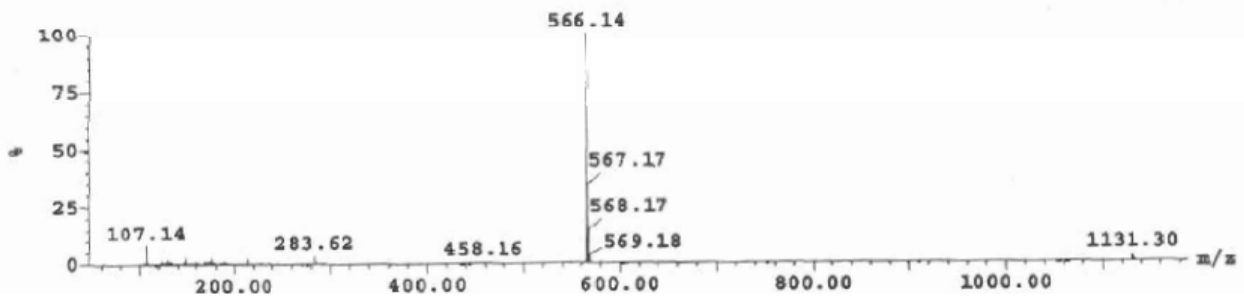




\section{n. Macrocycle 12r}
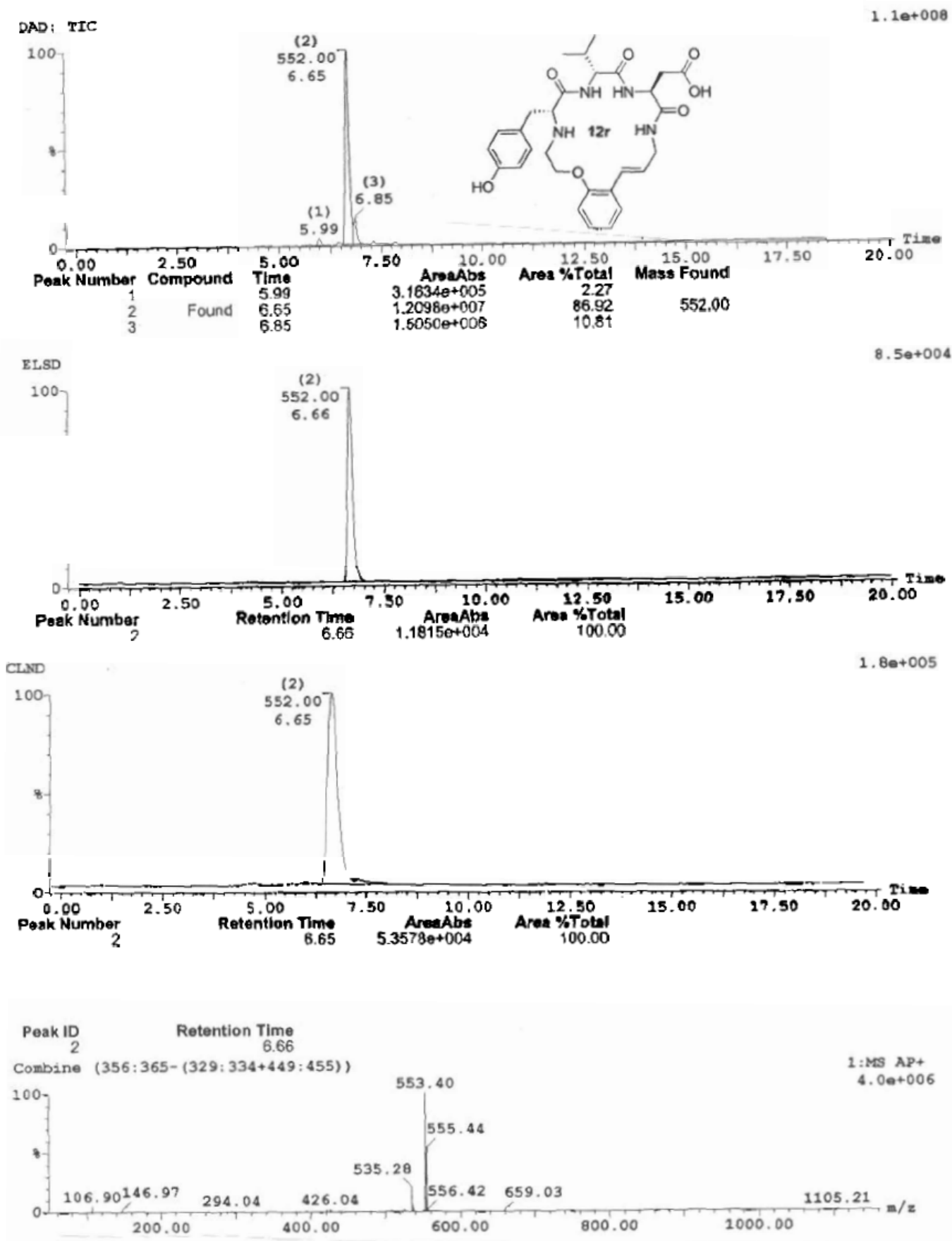

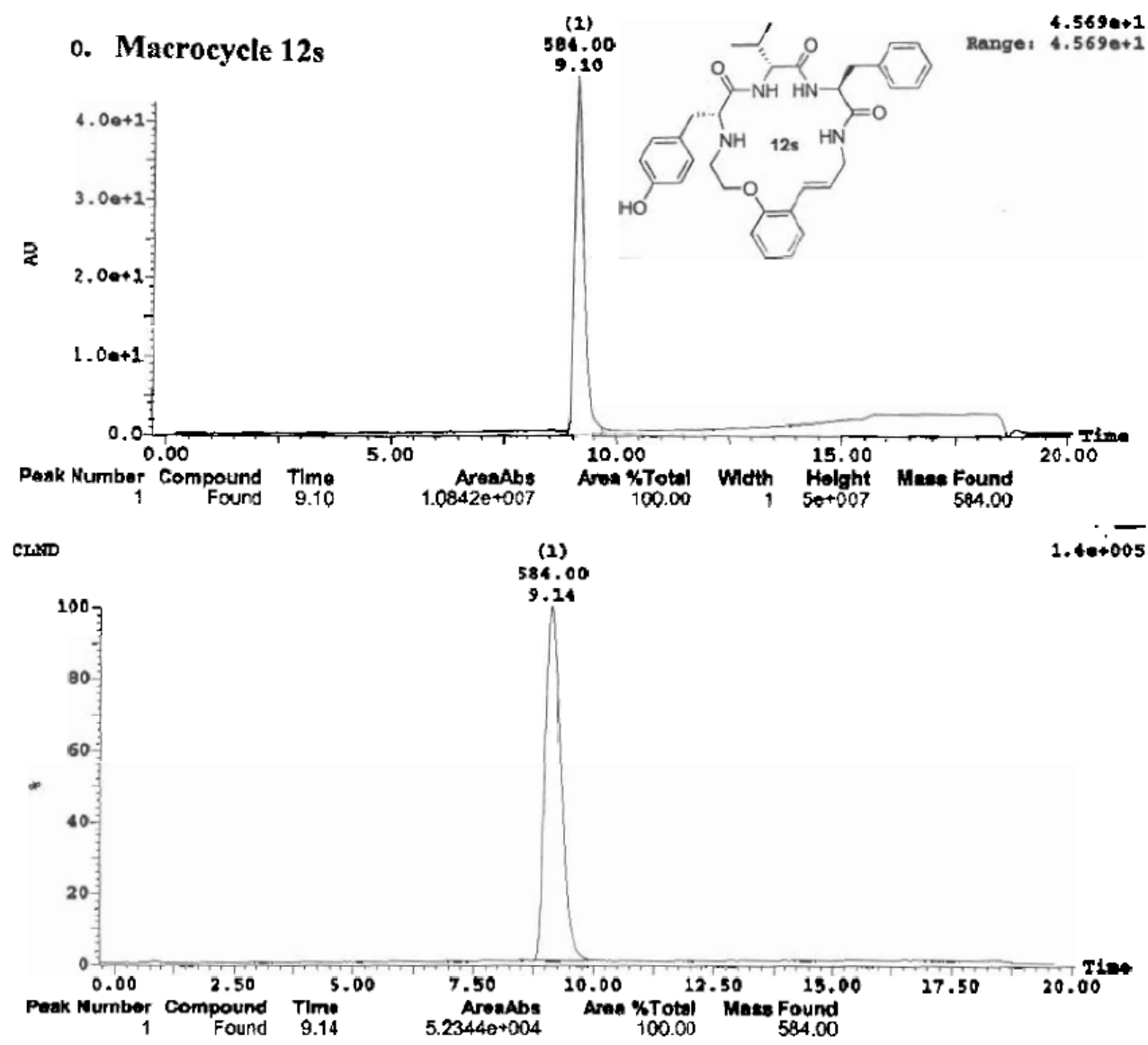

TISD

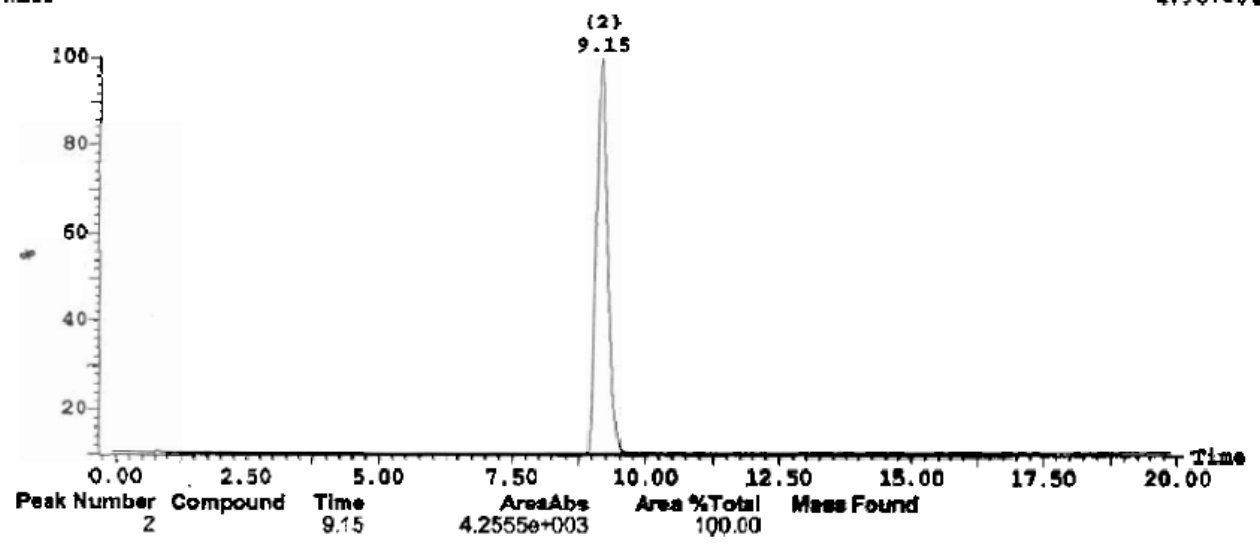

Peak ID Time

1. Combine $(343,350)$

1.26s $23+$

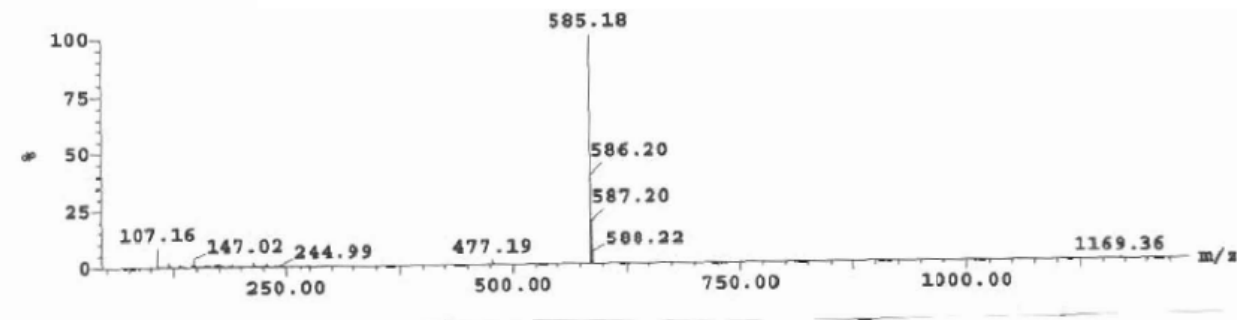



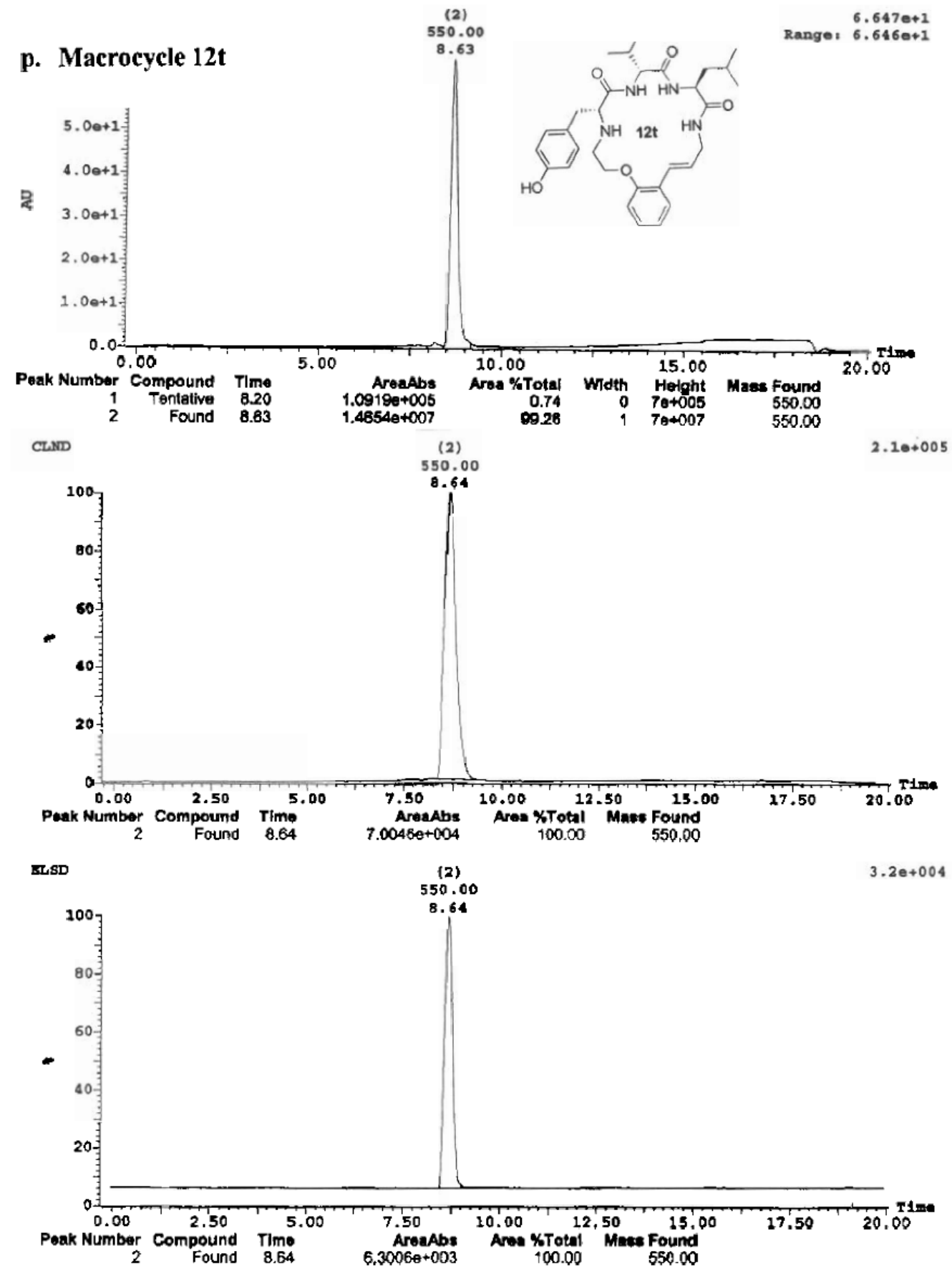

$\begin{array}{rr}\text { Peak ID } & \text { Time } \\ 2 & 8.64\end{array}$

2 : Combine $(357: 365) \quad$ 1:MS AP+

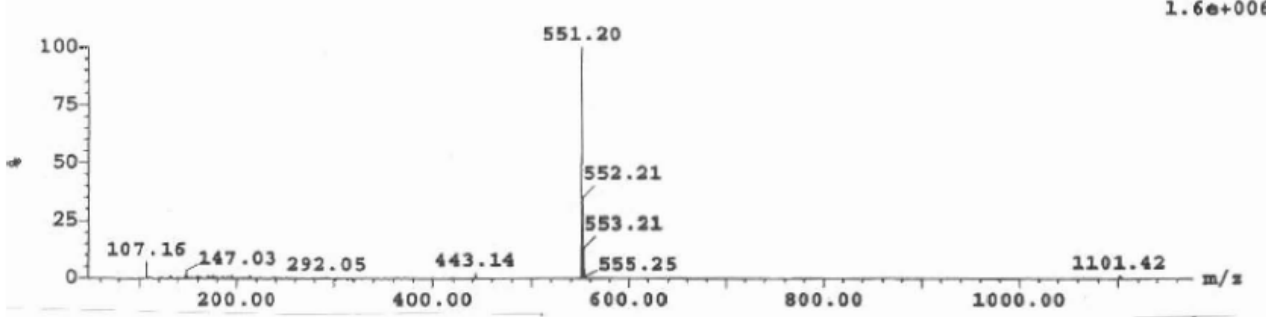




\section{q. Tripeptide 13a}
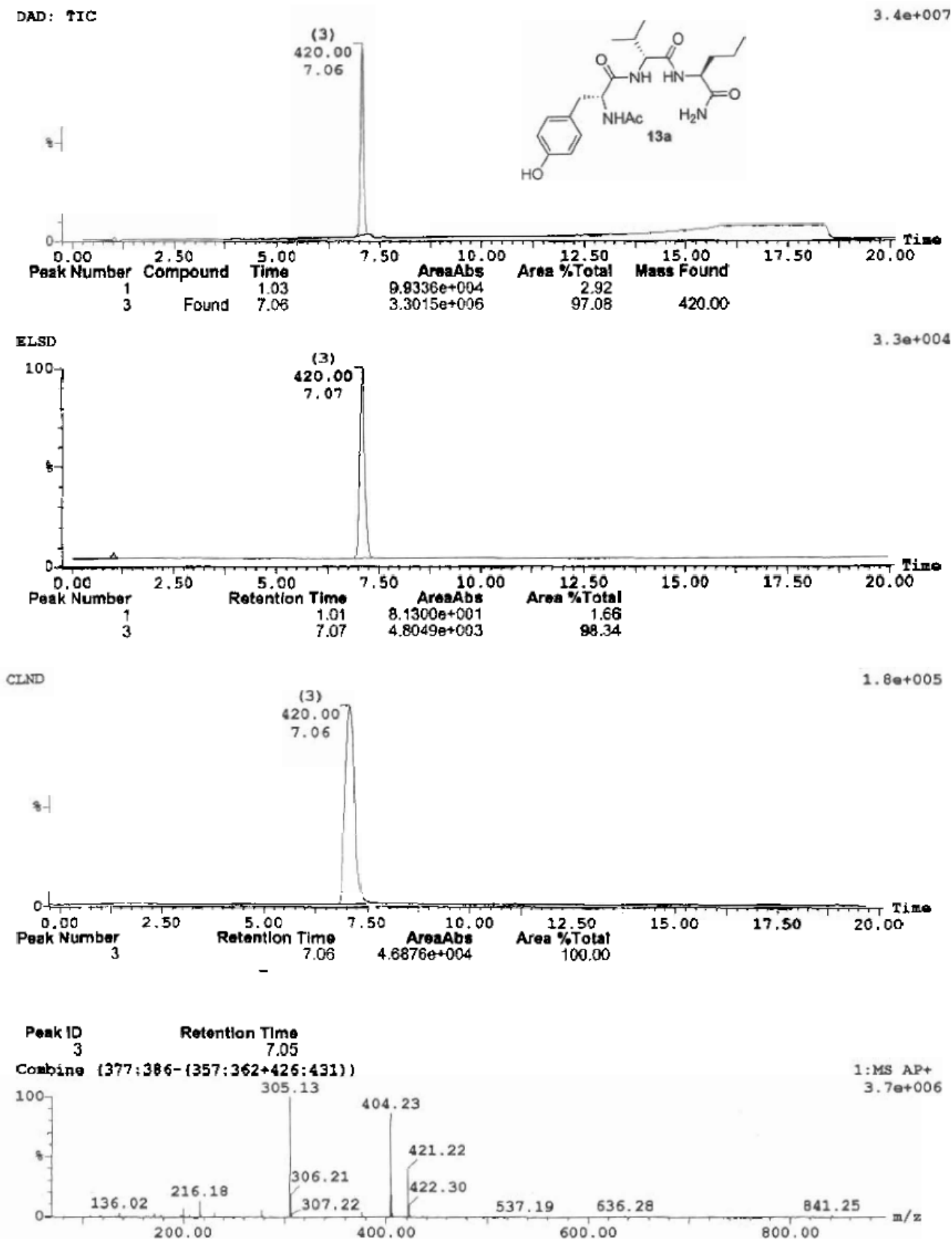


\section{r. Tripeptide 13b}
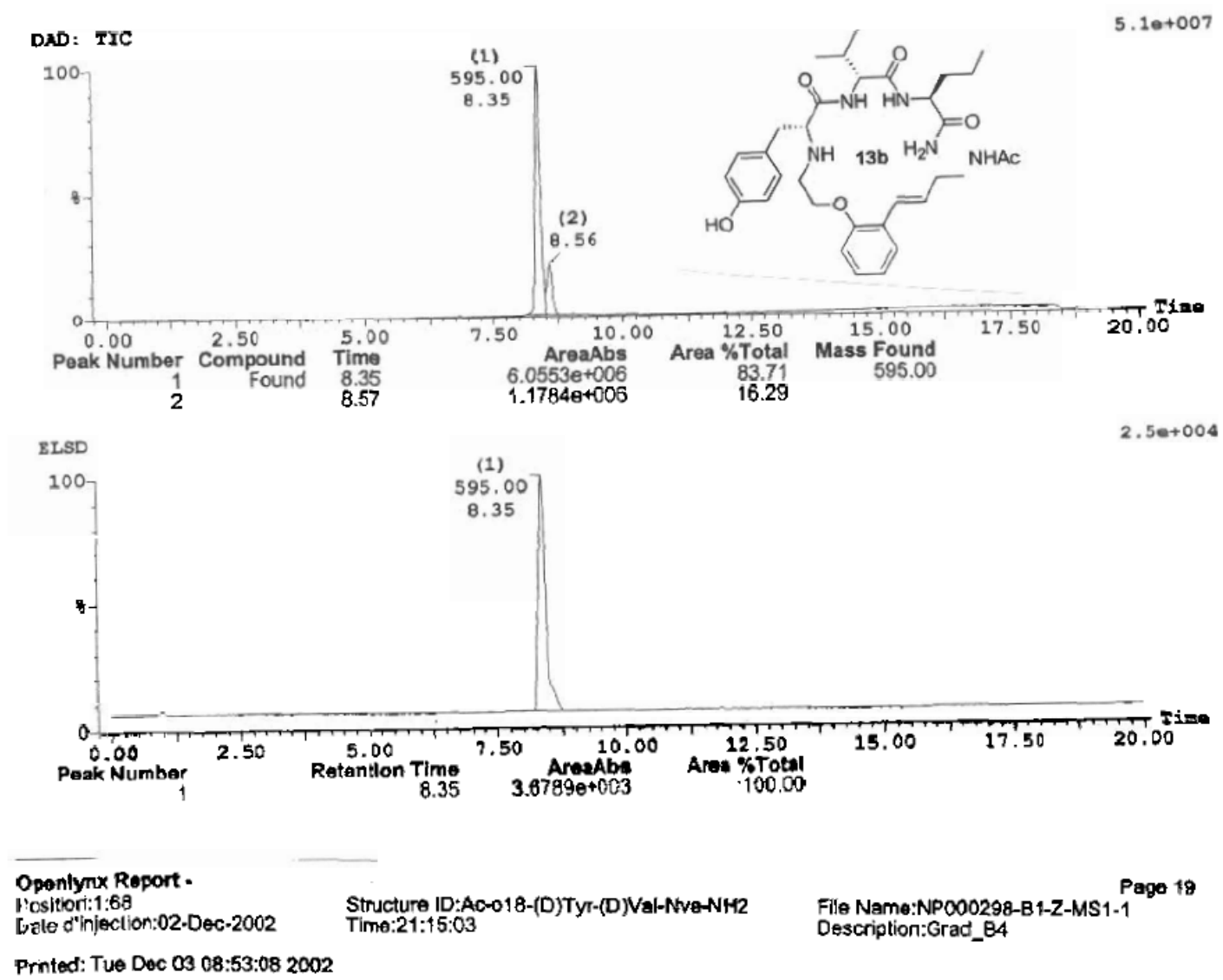

Printed: Tue Doc 03 08:53:08 2002

Sample Report (continued):

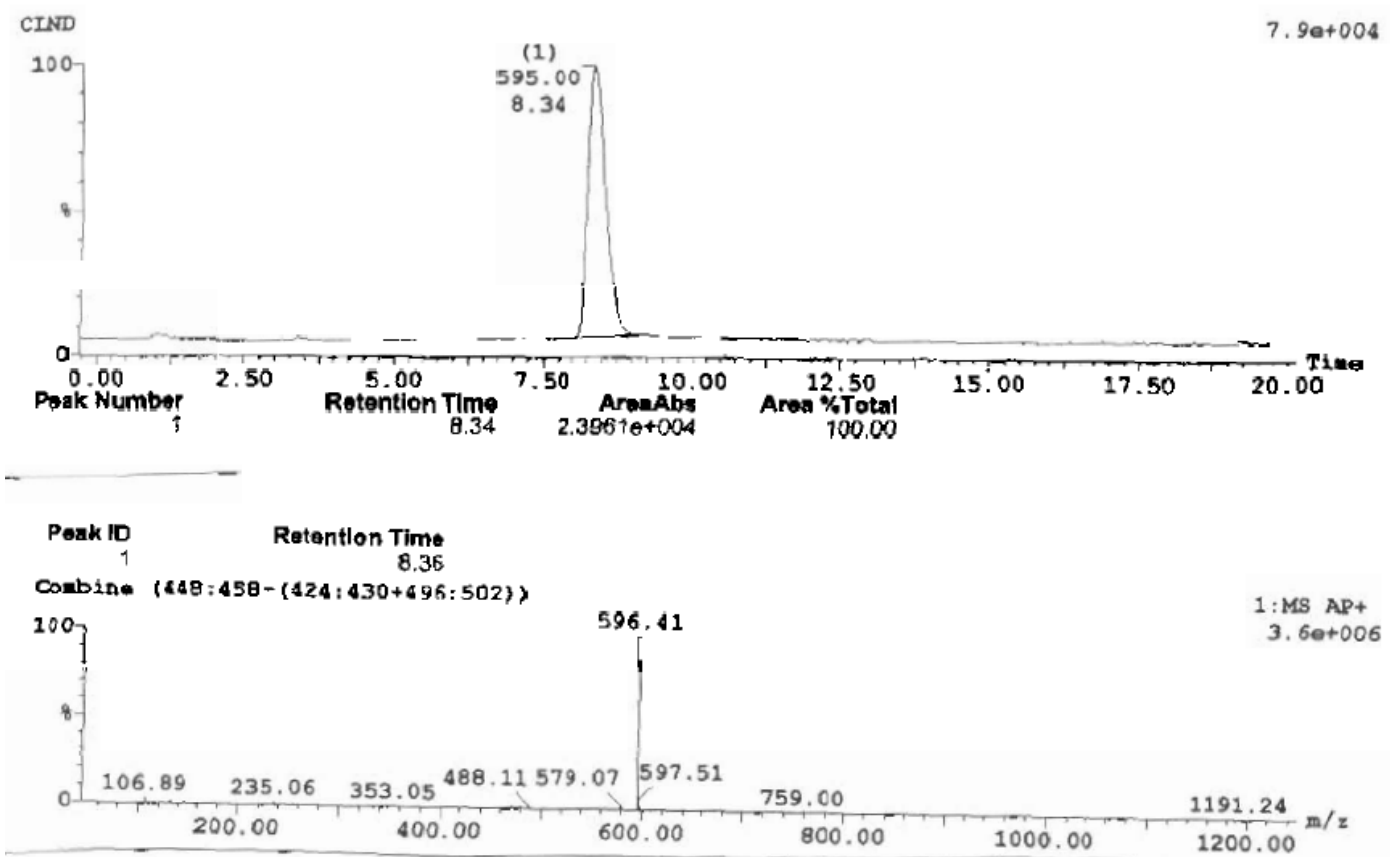




\section{s. Macrocycle 14b}
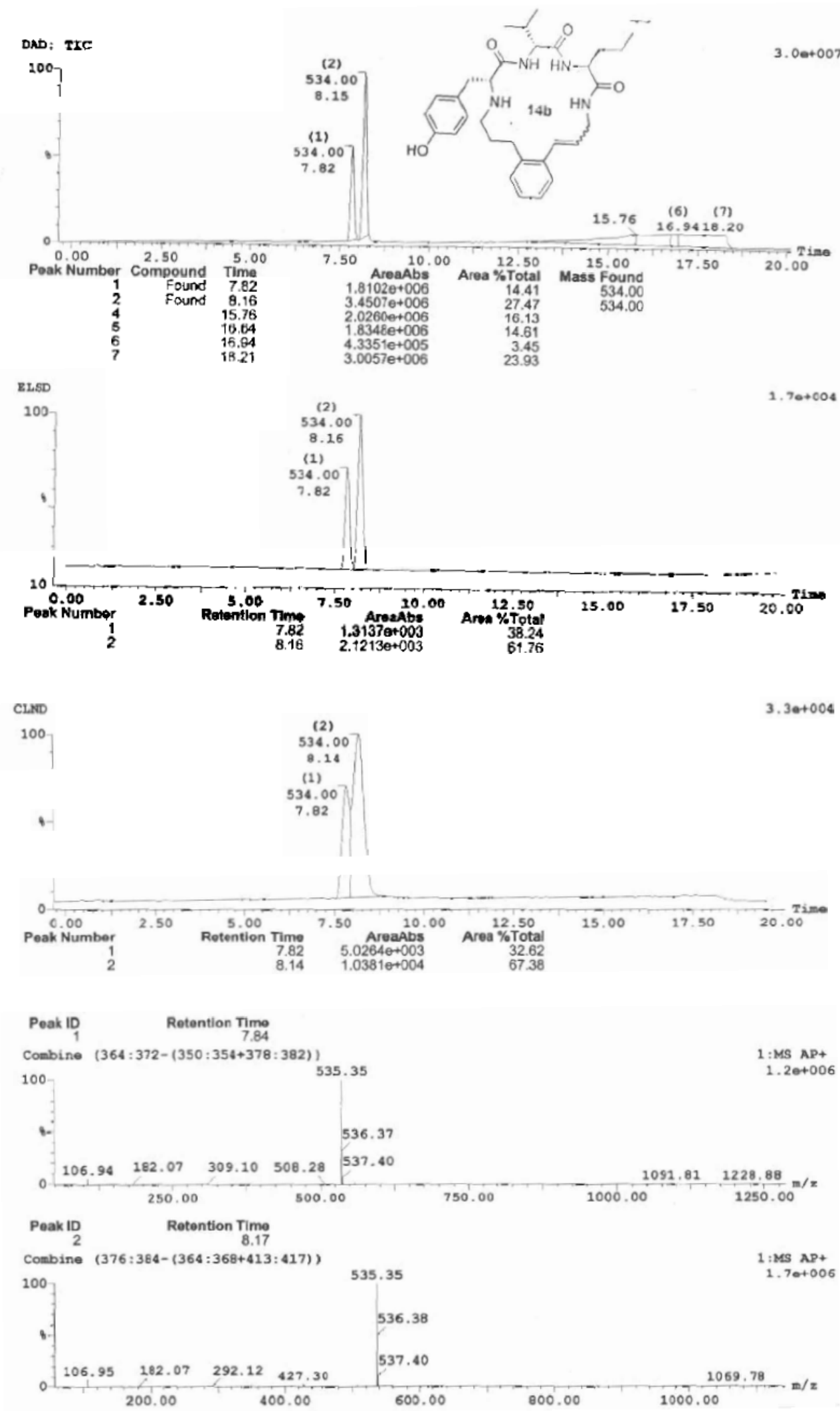
t. Macrocycle 14c
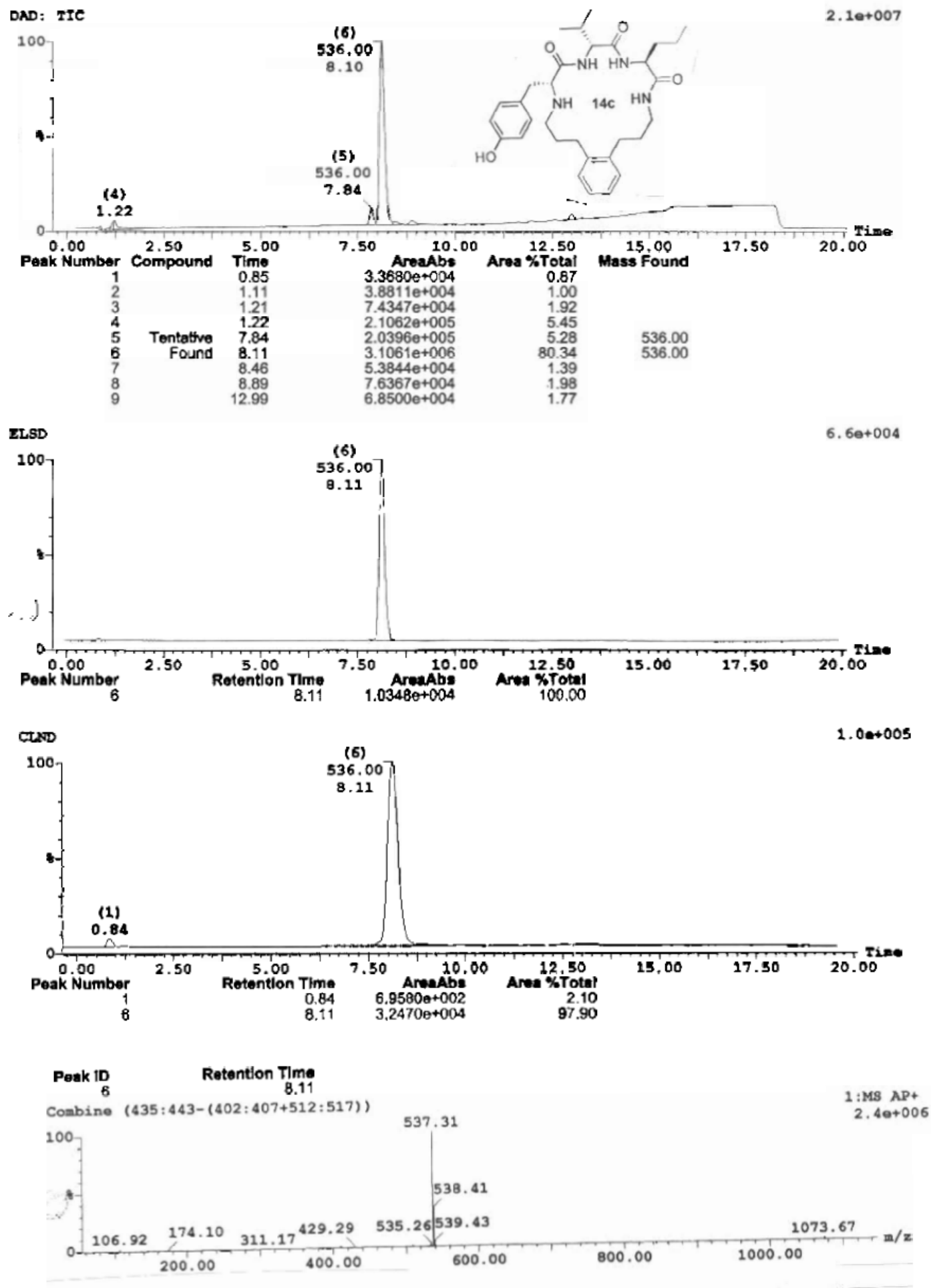
u. Macrocycle 14e
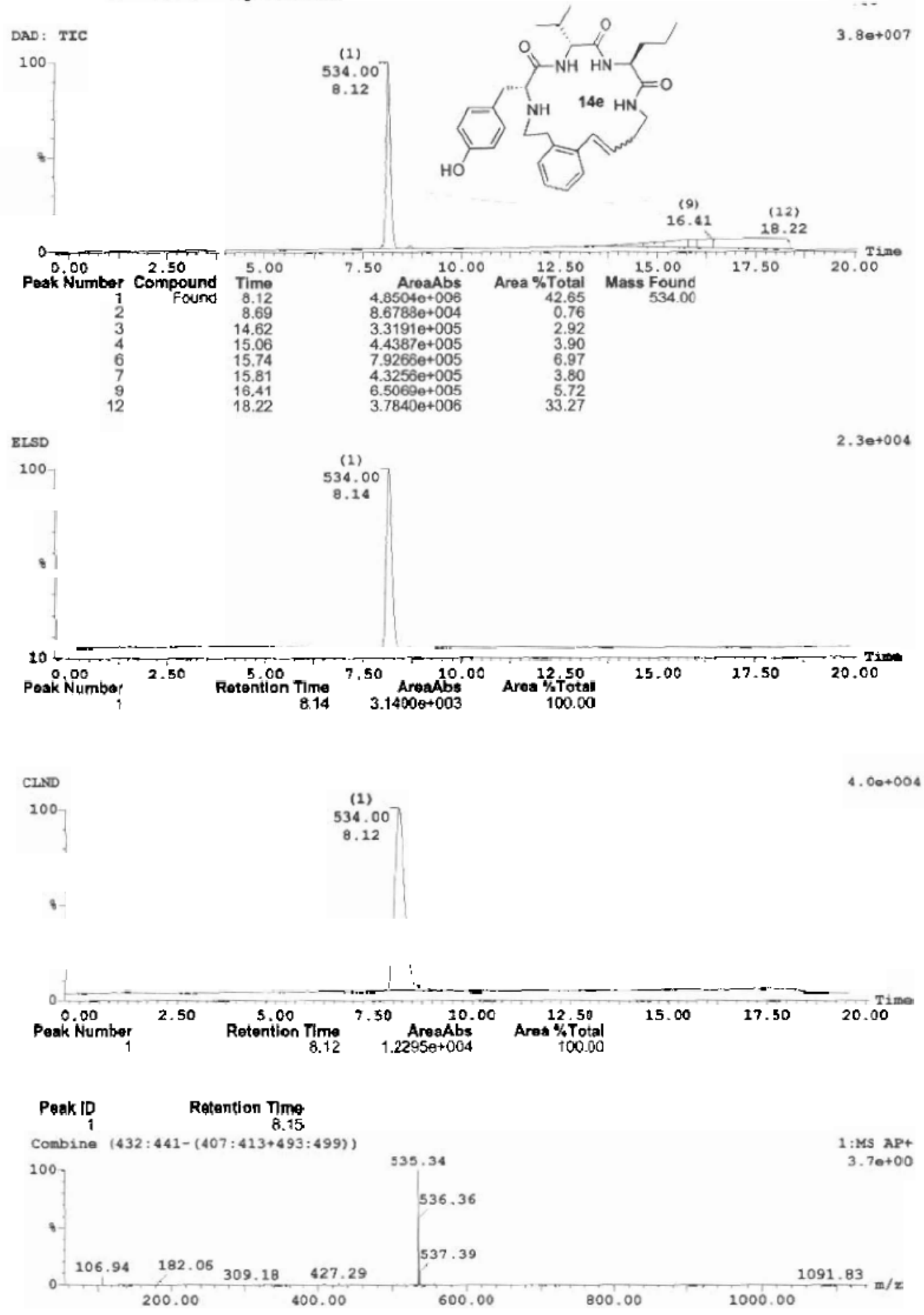


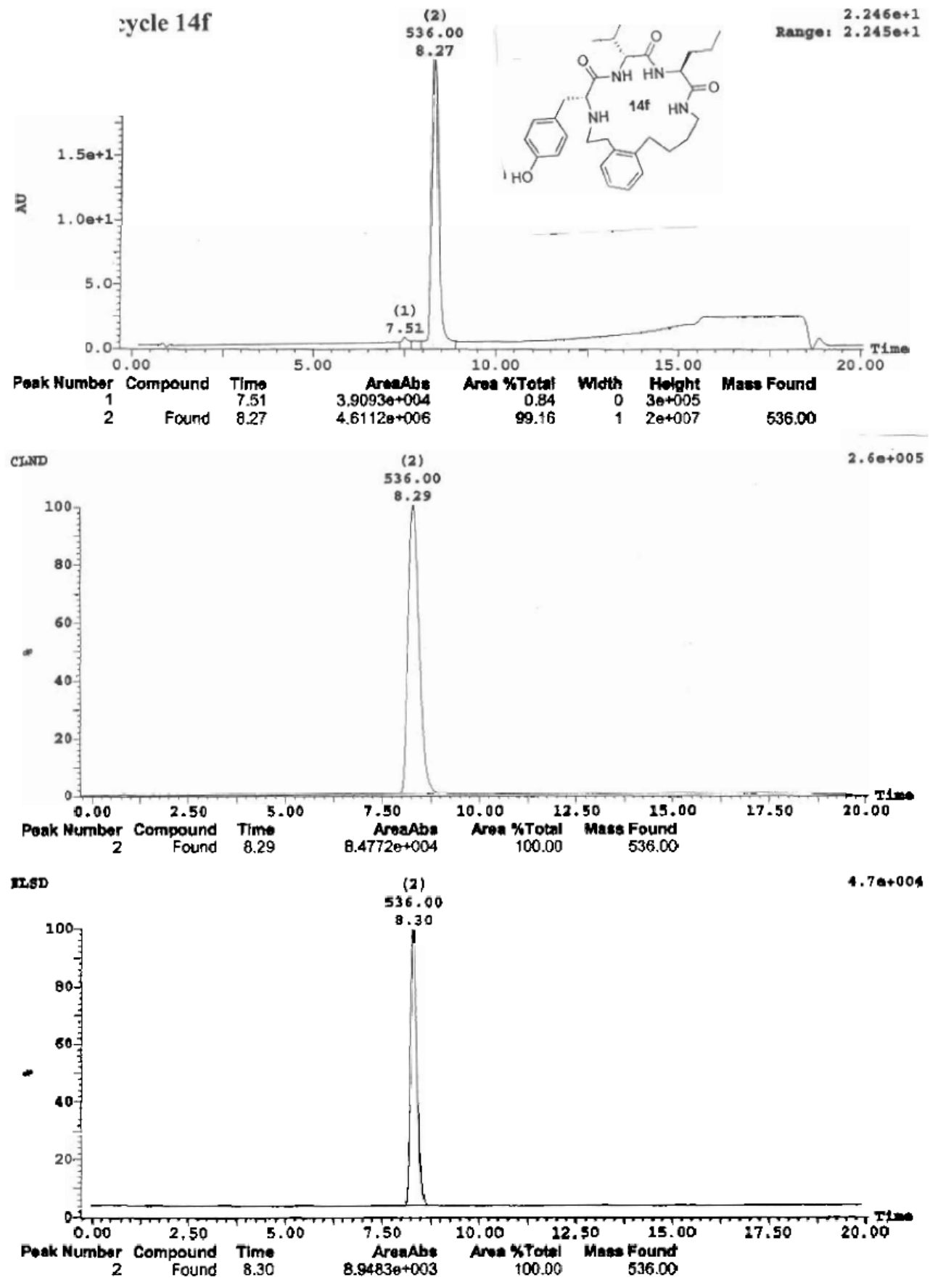

$\begin{array}{rr}\text { Peak ID } & \text { Time } \\ 2 & 8.30\end{array}$

2. Combine $(320,327)$

1, Mes AP+

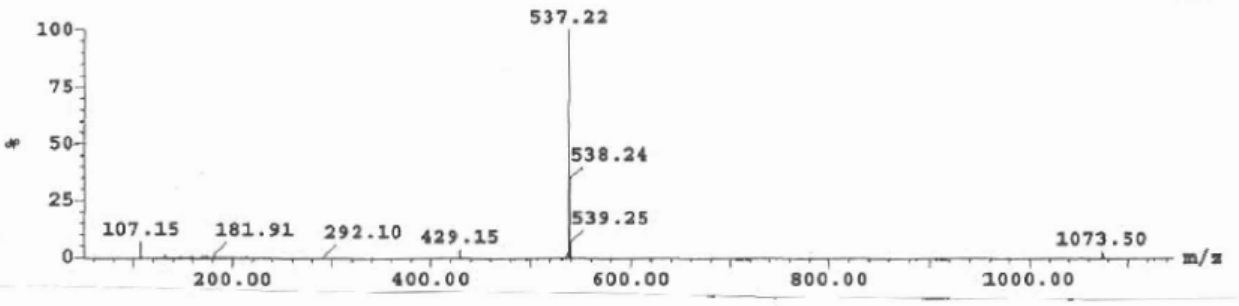


w. Macrocycle 14g
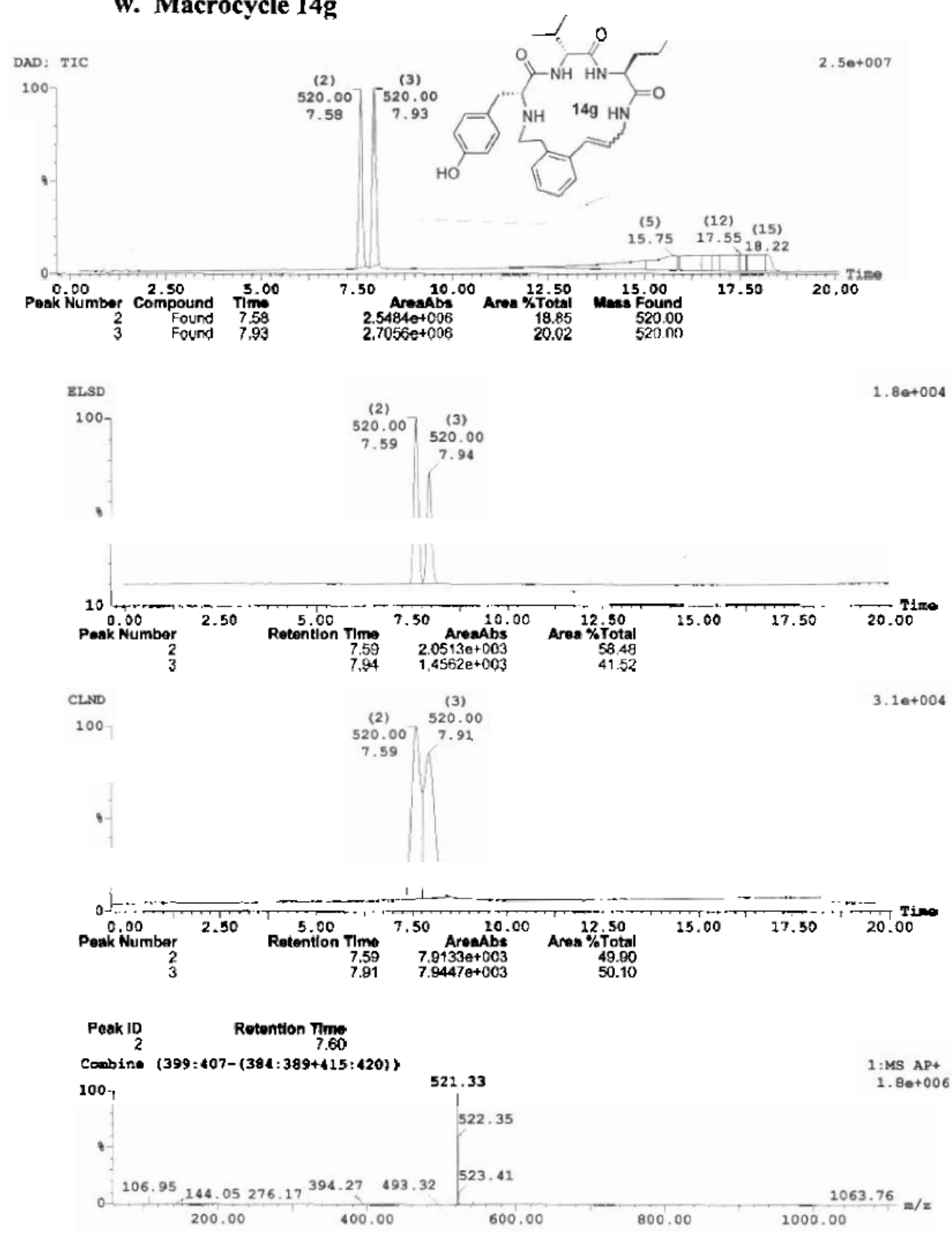

\section{Paak id 3 Retention Time}

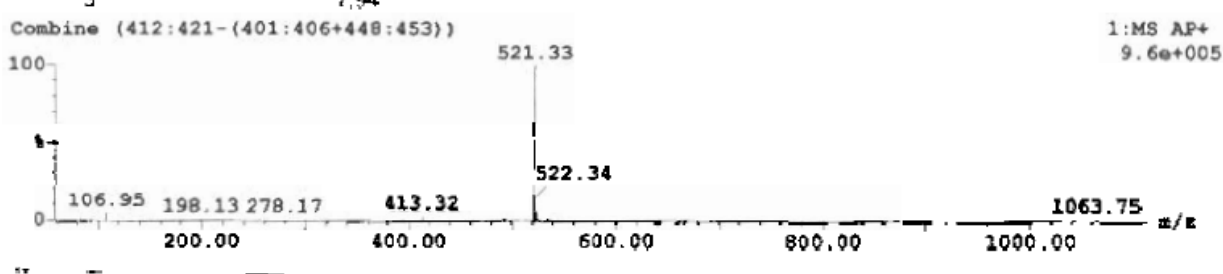



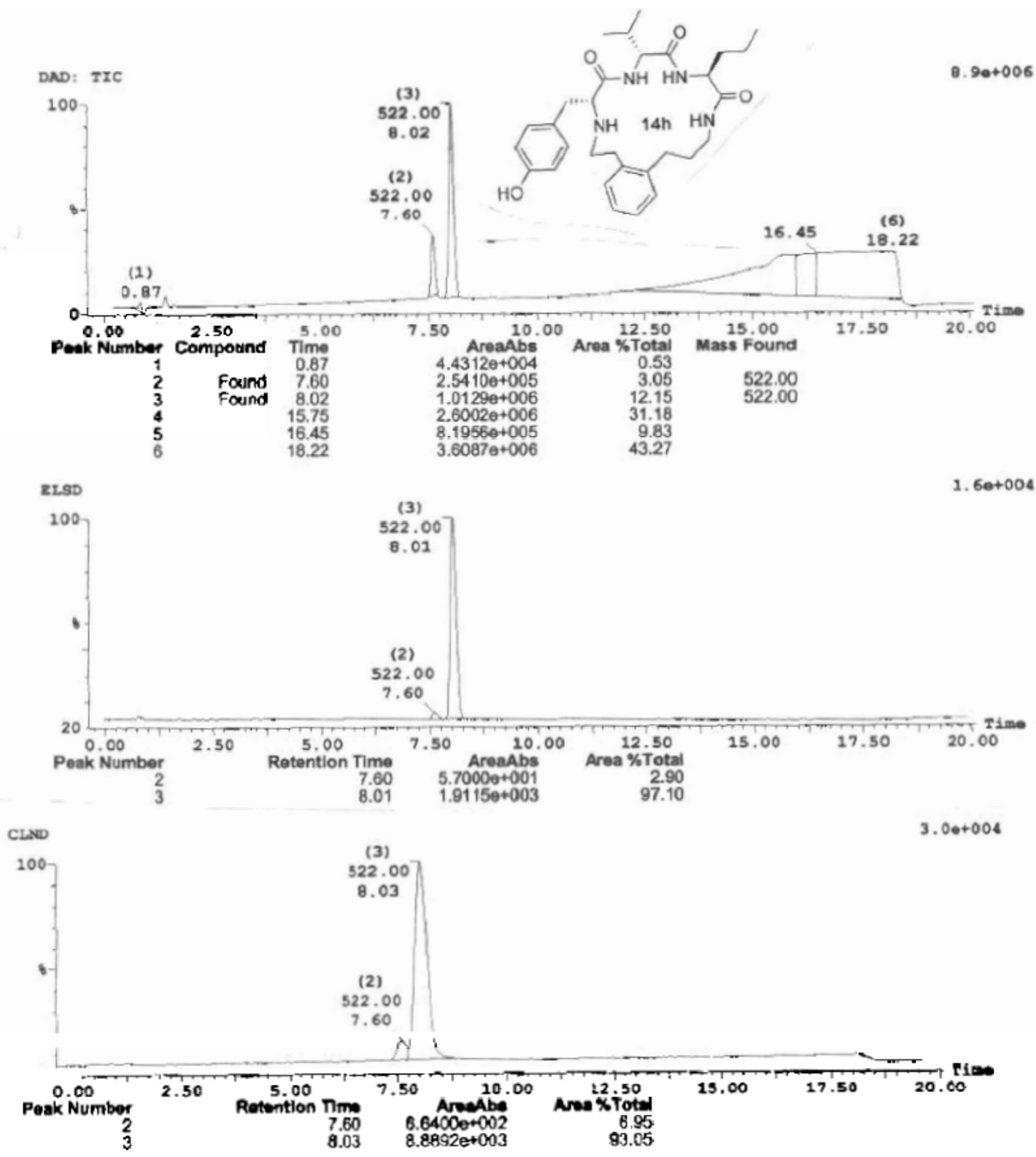

\section{Peak ID Retention Time}

Combine $(396: 404-(378: 383+441: 446))$

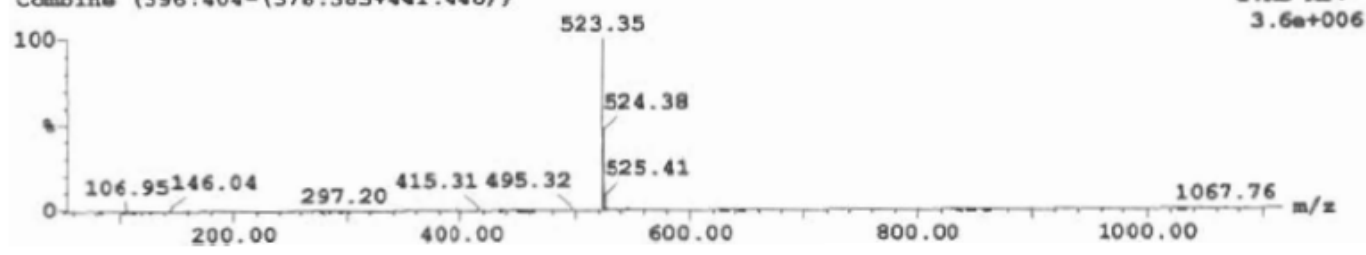




\section{y. Macrocycle $14 \mathrm{~m}$}
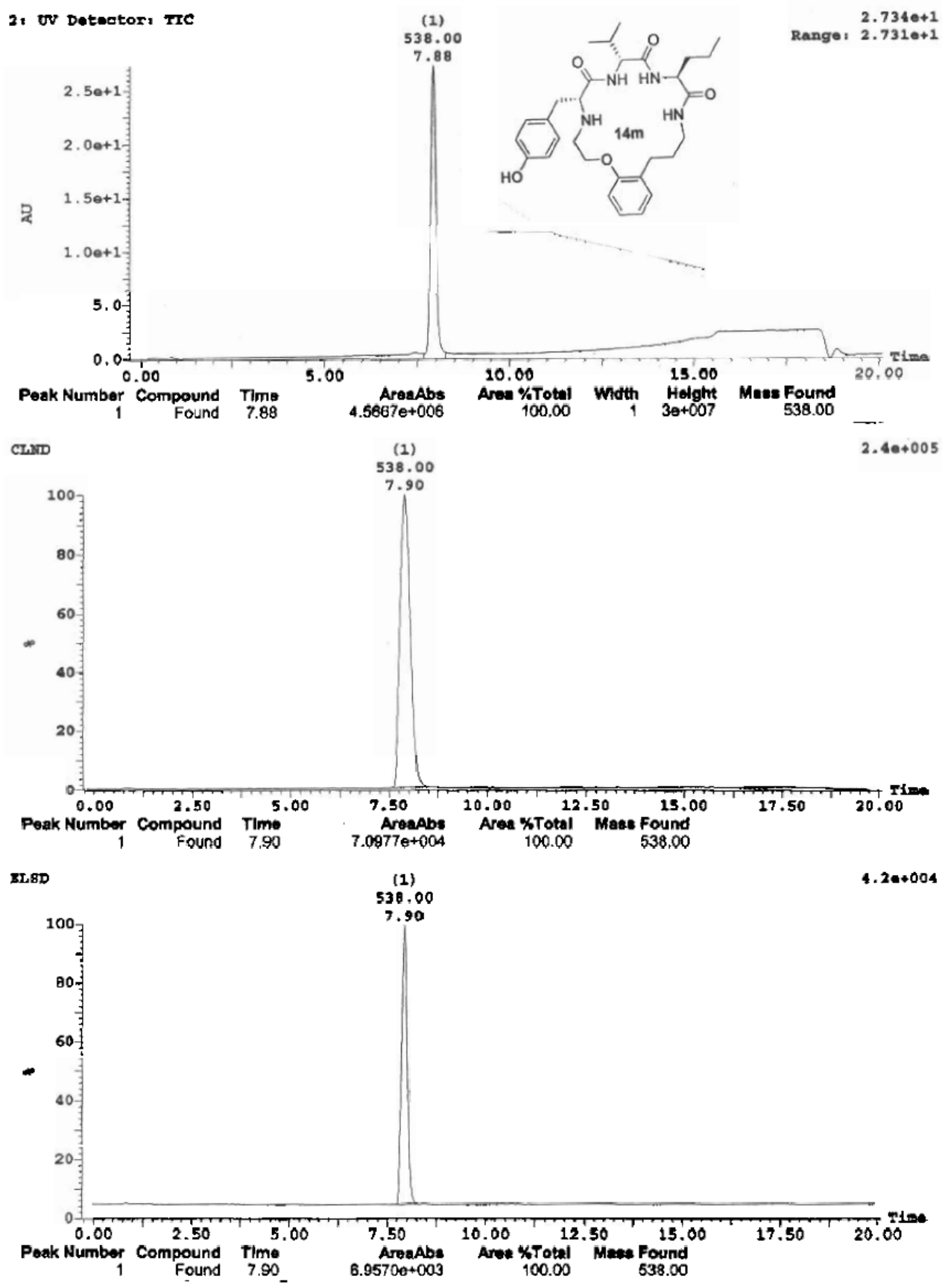

$$
\begin{array}{rr}
\text { Peak ID } & \text { Time } \\
1 & 7.89
\end{array}
$$

1. Combine (299:306)

$1: \mathrm{MS} \mathrm{AP+}$

$1.9 \bullet+006$

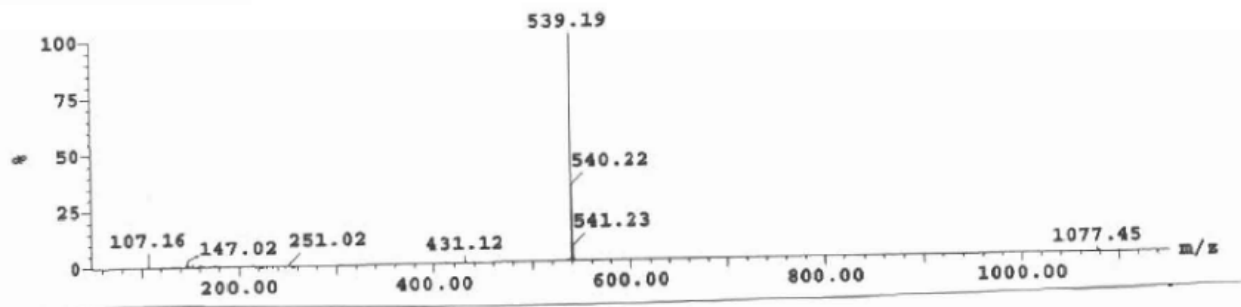


cycle 14n
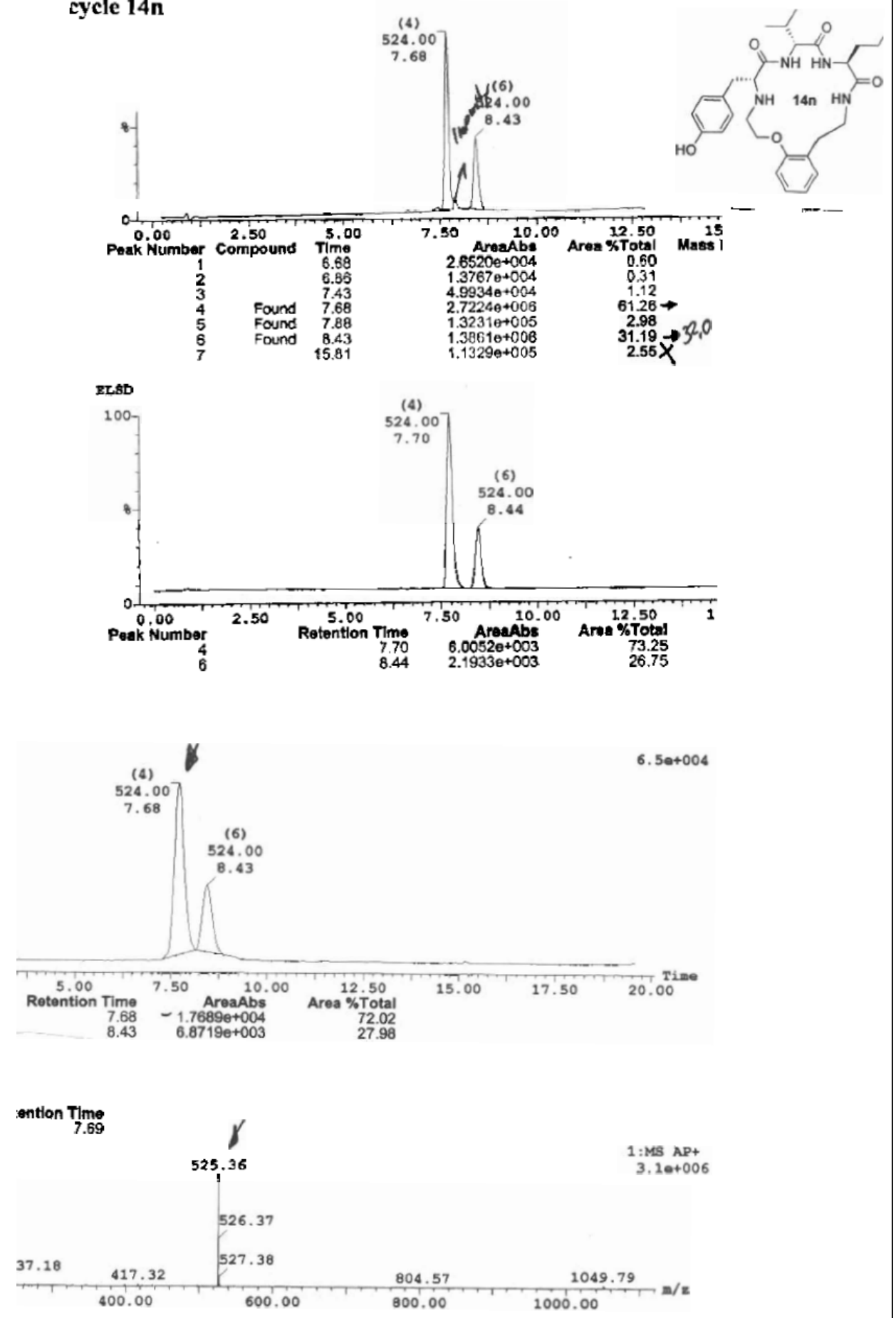

intion Time

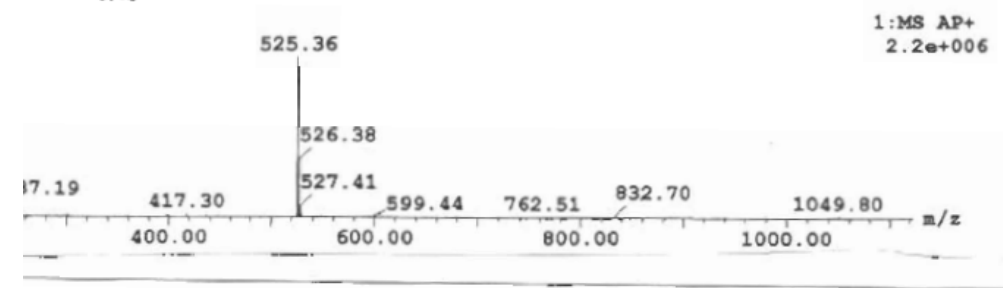




\section{- cycle $15 a$}

DAD: TIC

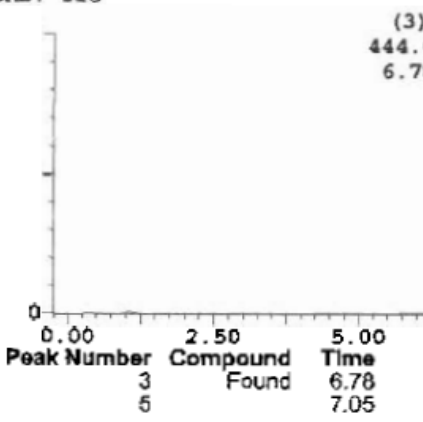

(3) 4.00 6.78 $(5)$
7.05

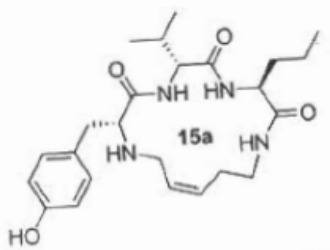

4. $8 e+007$

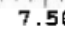

AreaAbs

$7.26320+006$

Area \% Total 25.00

\%otal Mass Found

96.63

444.00

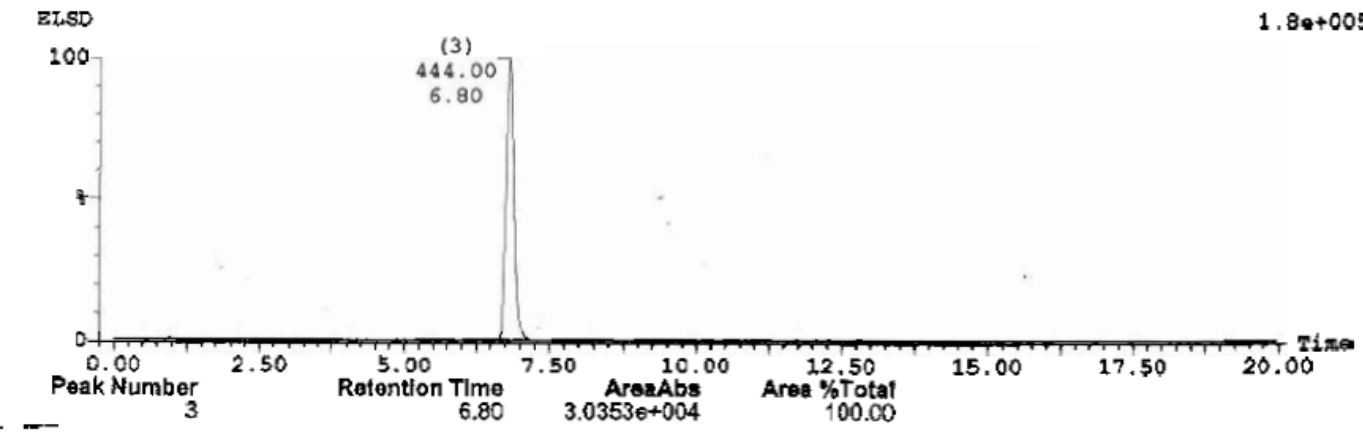
- -

CLND

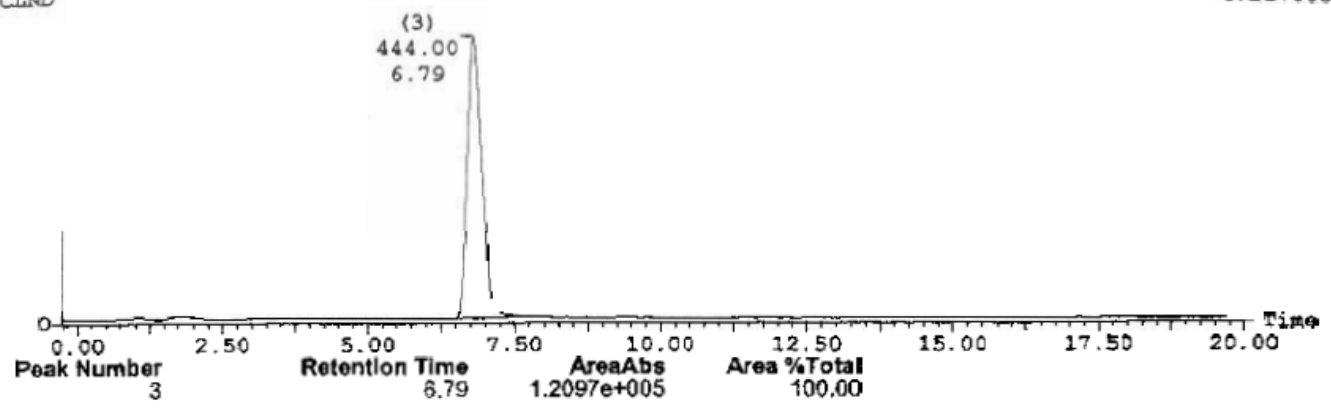

\section{Peak ID Retention Time}

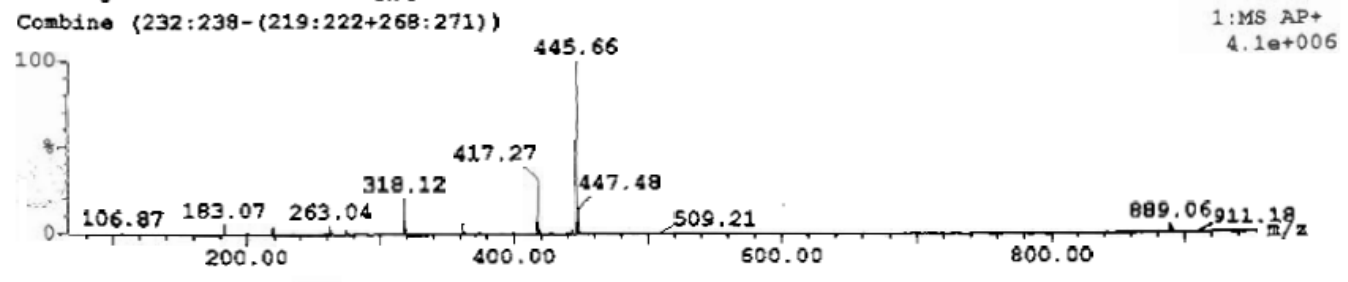




\section{bb. Macrocycle 15b}

Flle Name MOTL003_062_B2_Z_MS2
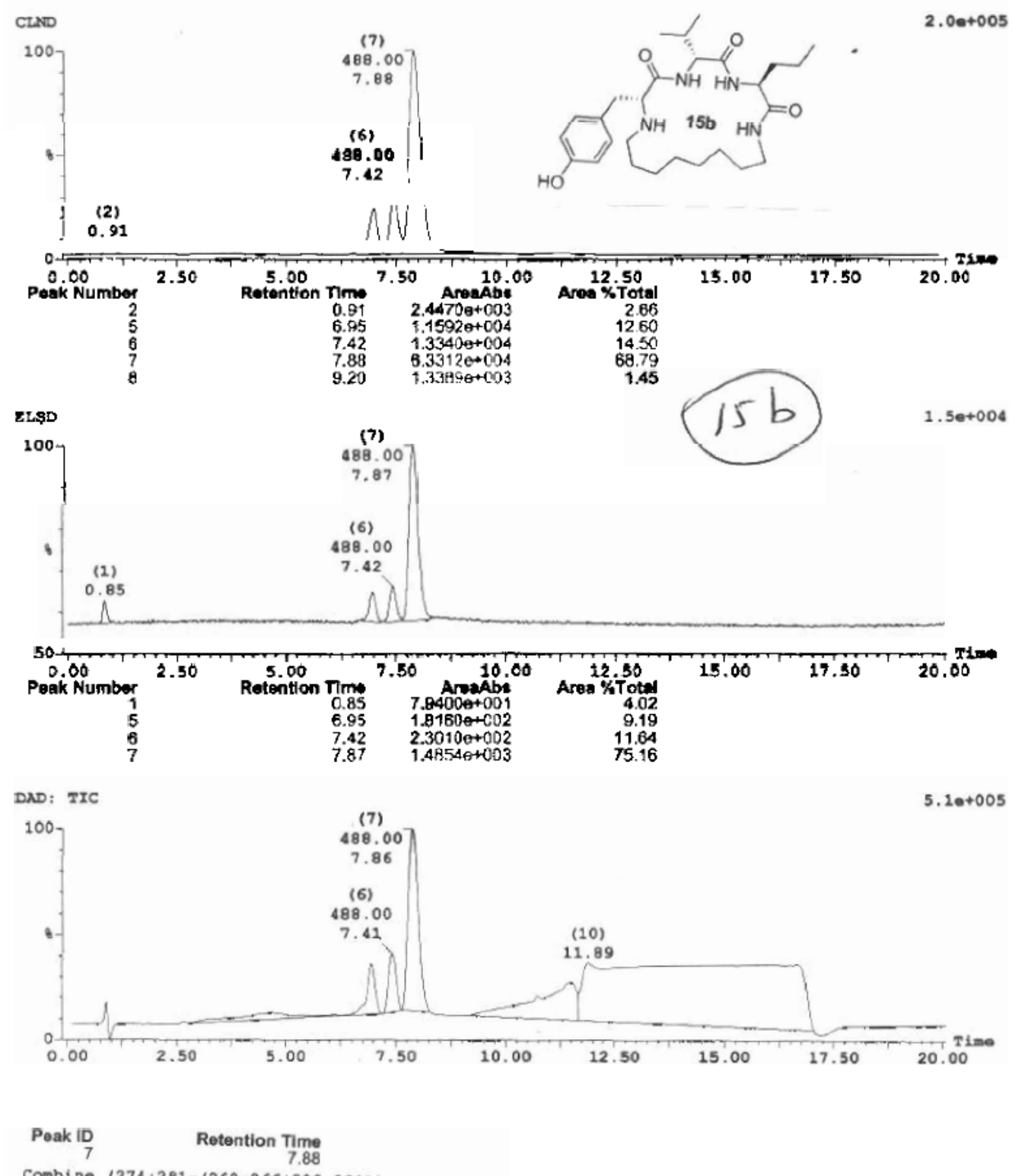

Combine (274:281-(262:266+328:331))
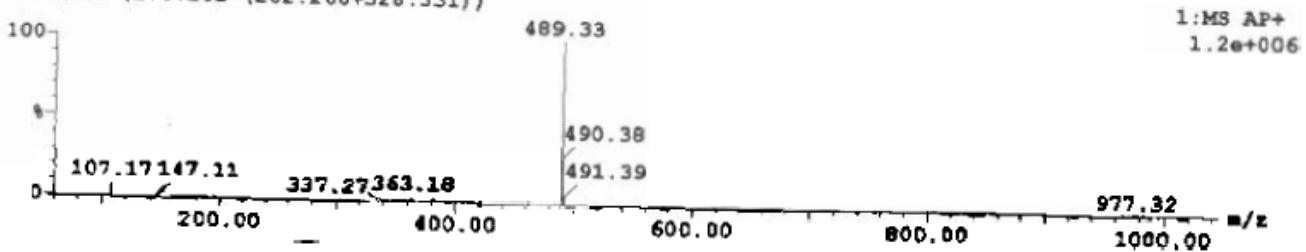

$200.00-100.00$

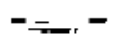

1000.00 


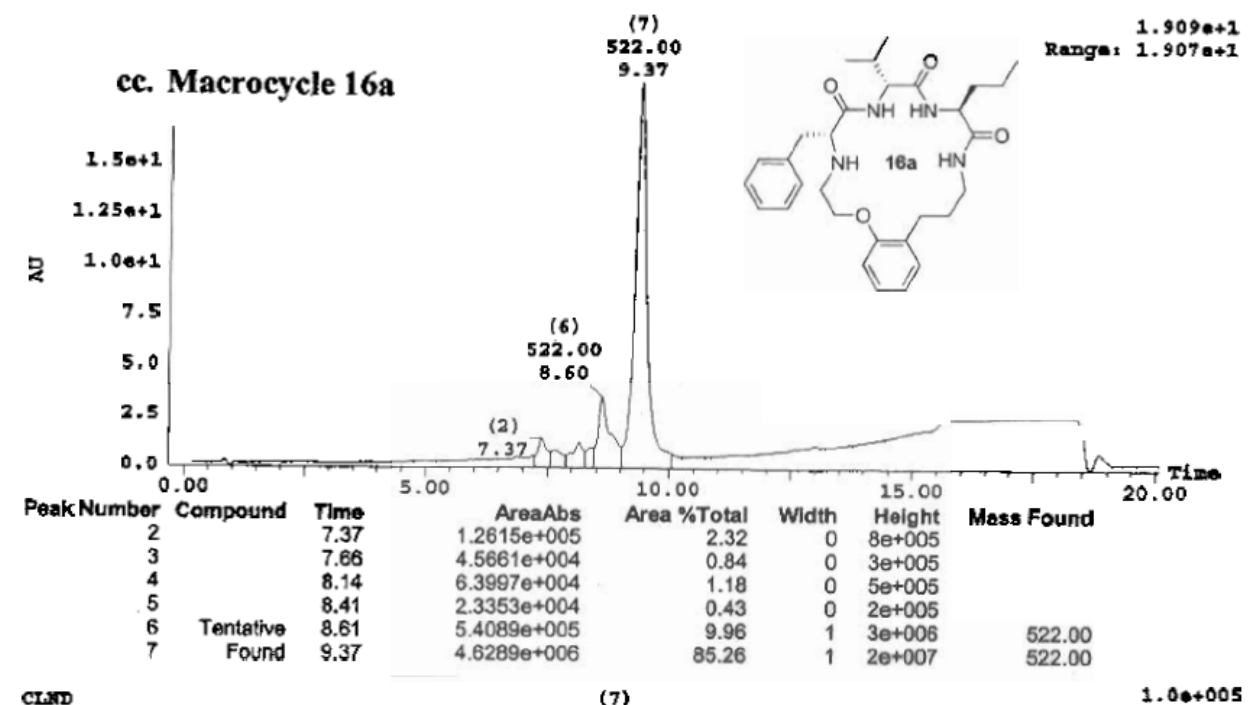

CIND

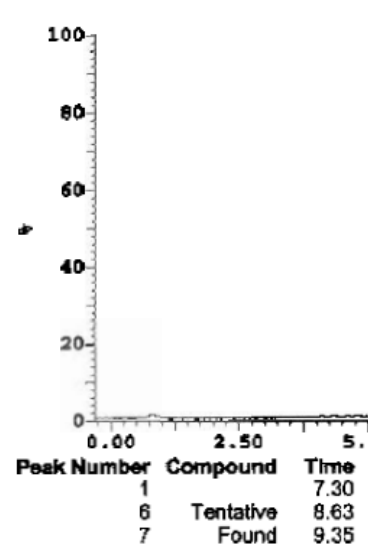

522.00

$1.00+005$

3LSD
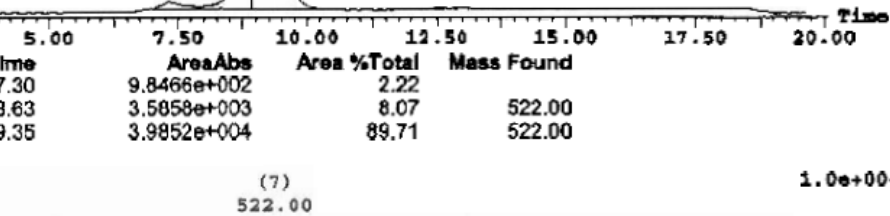

$1.00+004$
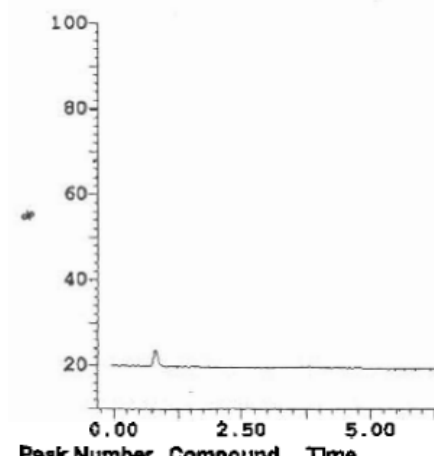

7 Found Thme

Peak ID
$7 \quad 9.35$

1. Combine (350,358)

$1,129 \mathrm{NP}+$

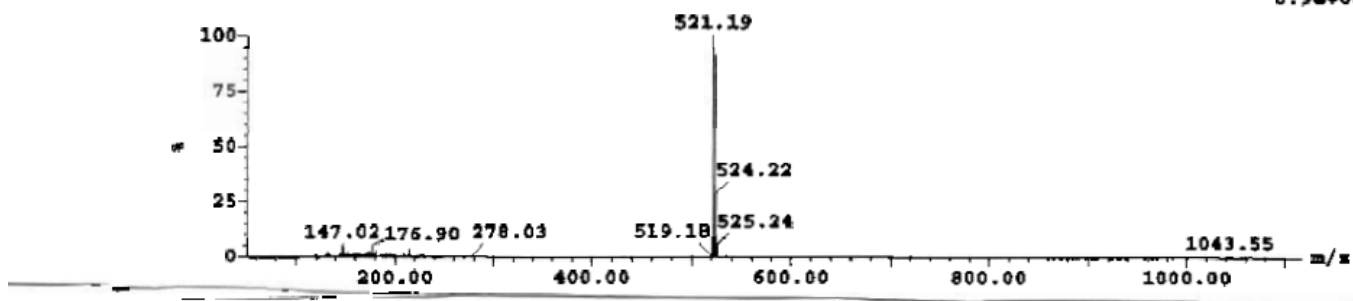




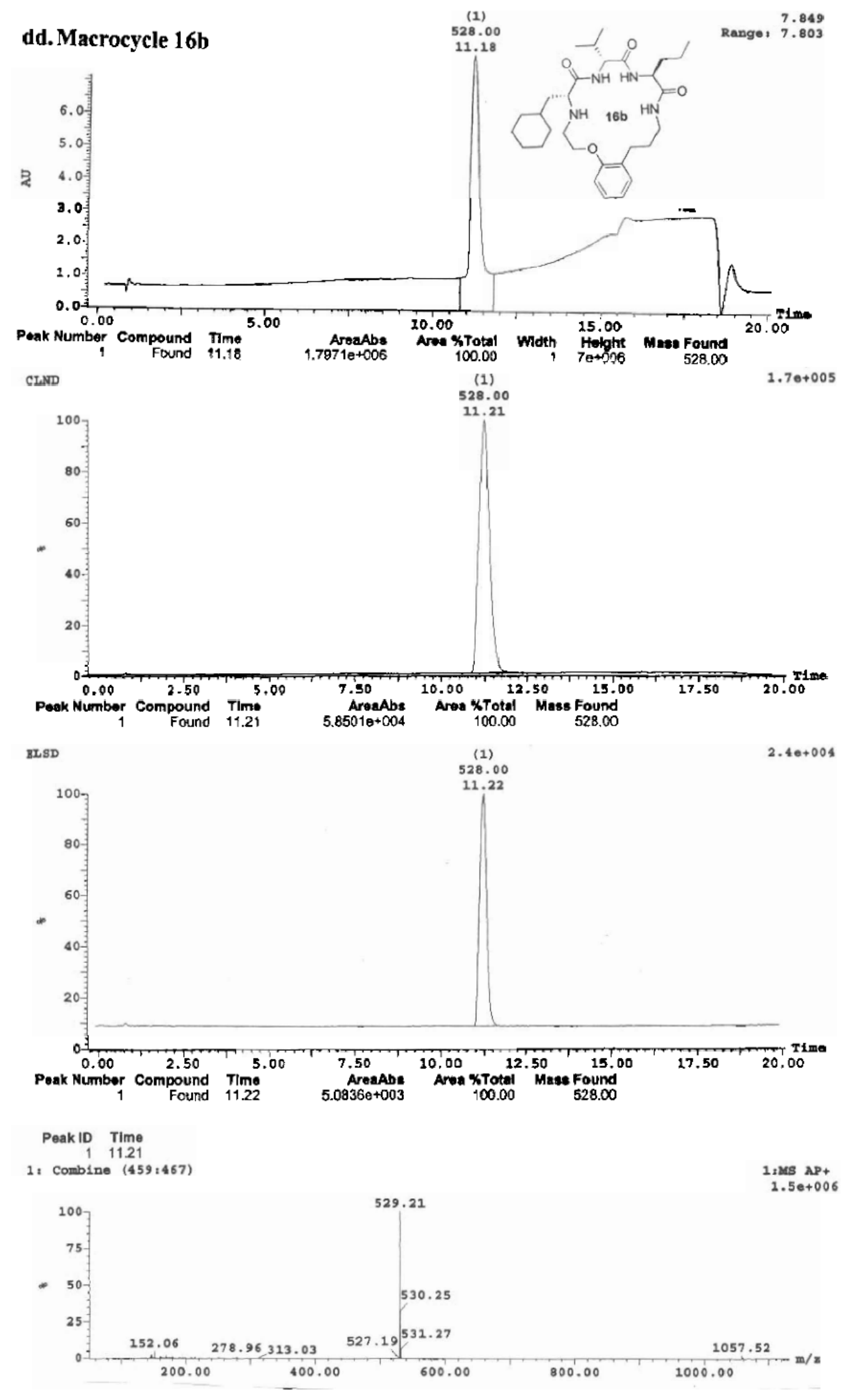



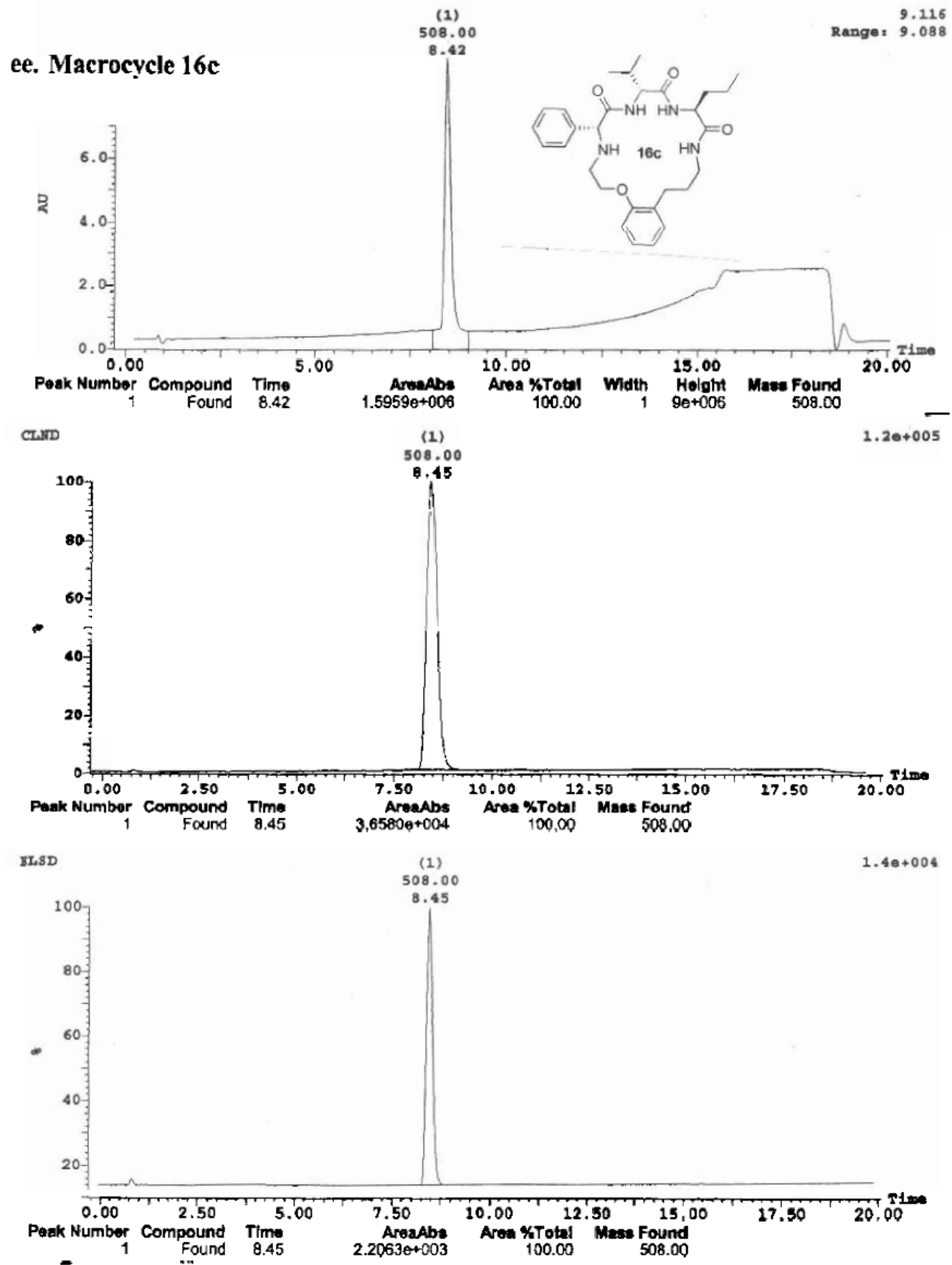

Pank ID Timo

1 Penk ip 8.43

1. Combint (334,341)

$1, \mathrm{MS} \mathrm{AP+}$

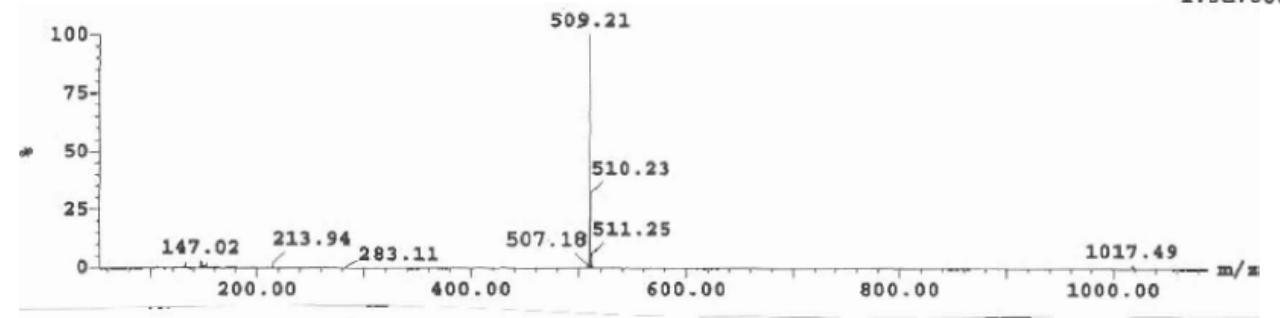


ff. Macrocycle 16d

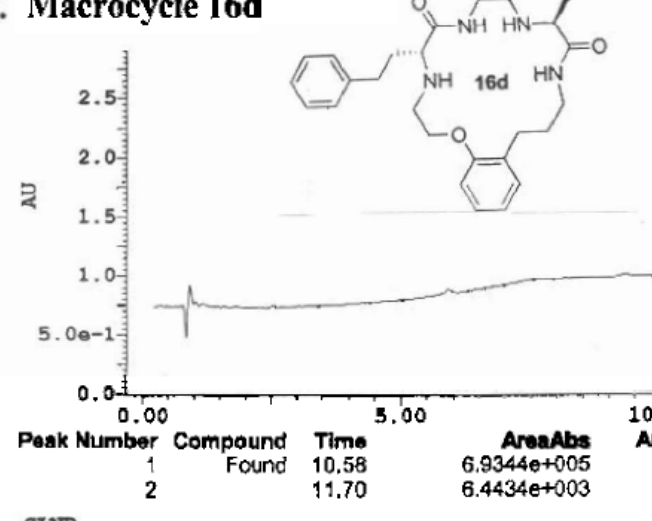

$536.00 \quad$ Range: $\begin{aligned} & 3.364 \\ & 3.314\end{aligned}$

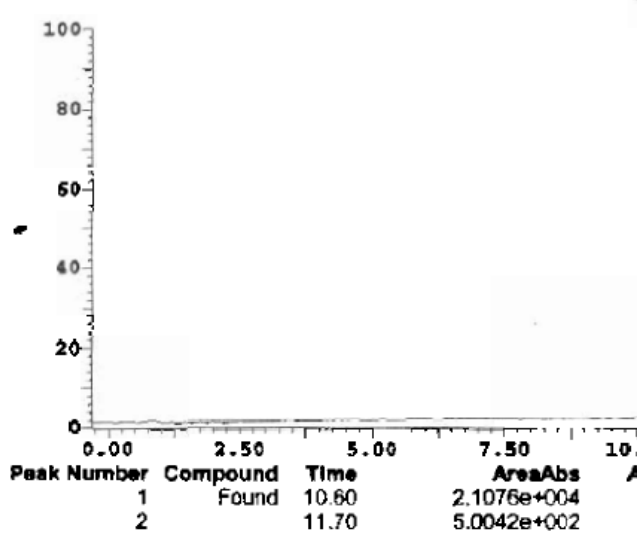

$(1)$
536.00

sLSD

10.60

$\begin{array}{rrr}\text { Woth } & \begin{array}{c}15.00 h \\ \text { Holght } \\ 2 \theta+006\end{array} & \text { Mass Found } \\ 538.00\end{array}$

$0 \quad 50+004$
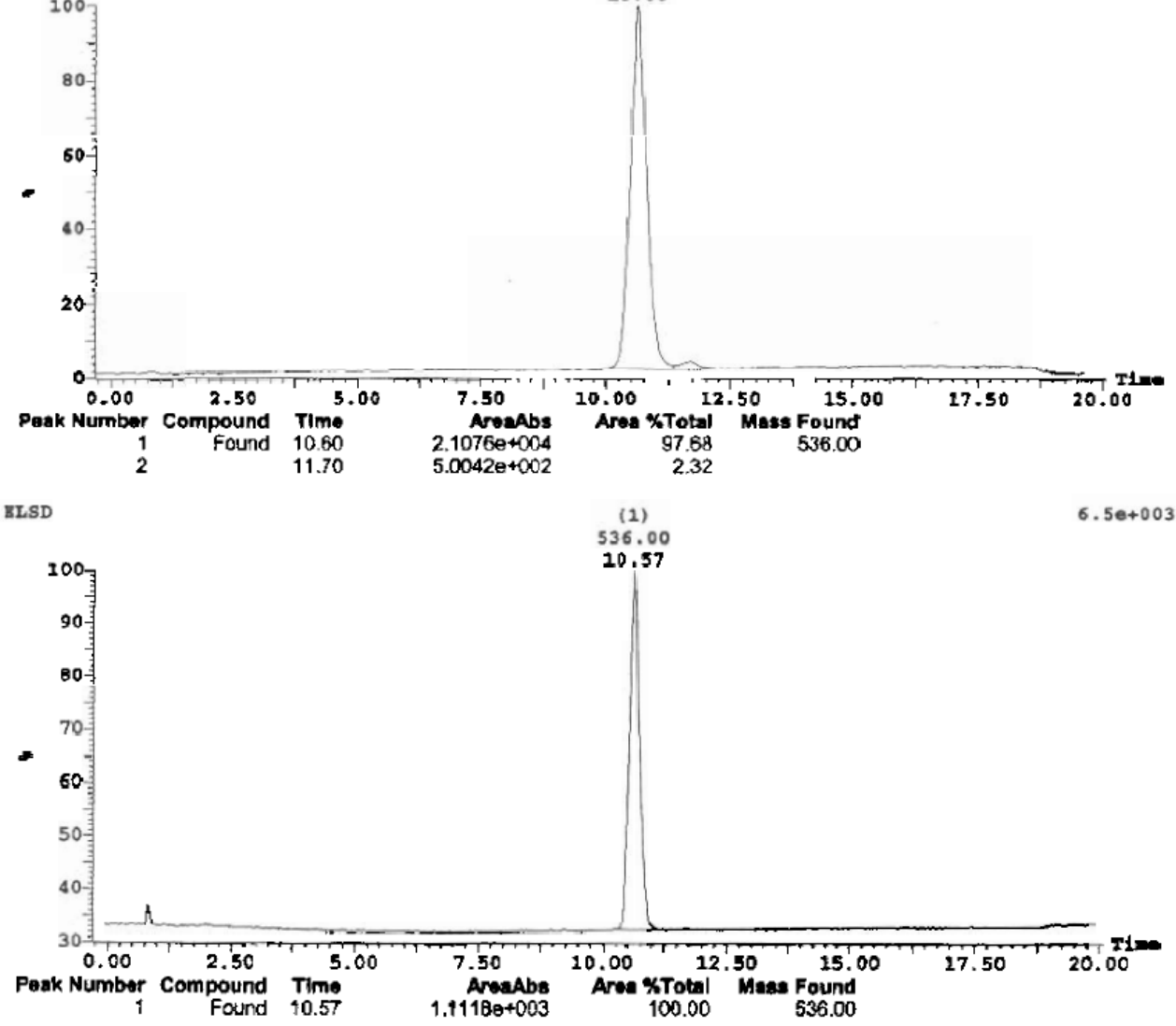

Peak ID ${ }_{1}$ Time

12 Combine $(398,406)$

1 : MES AP+

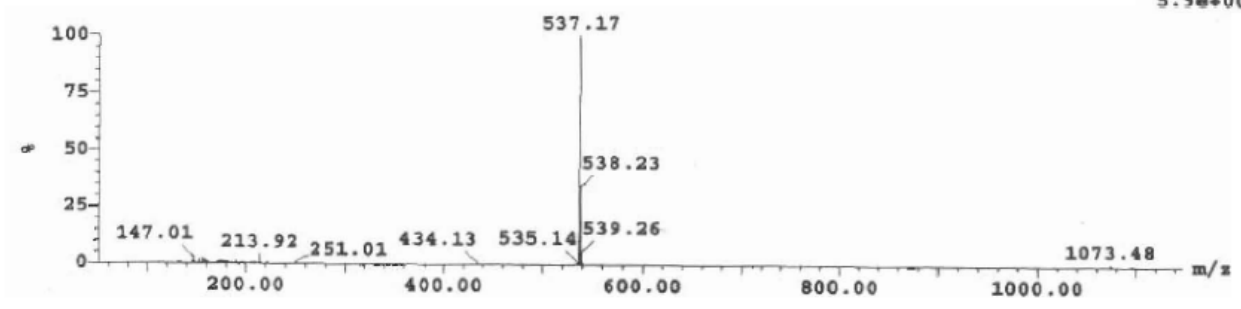




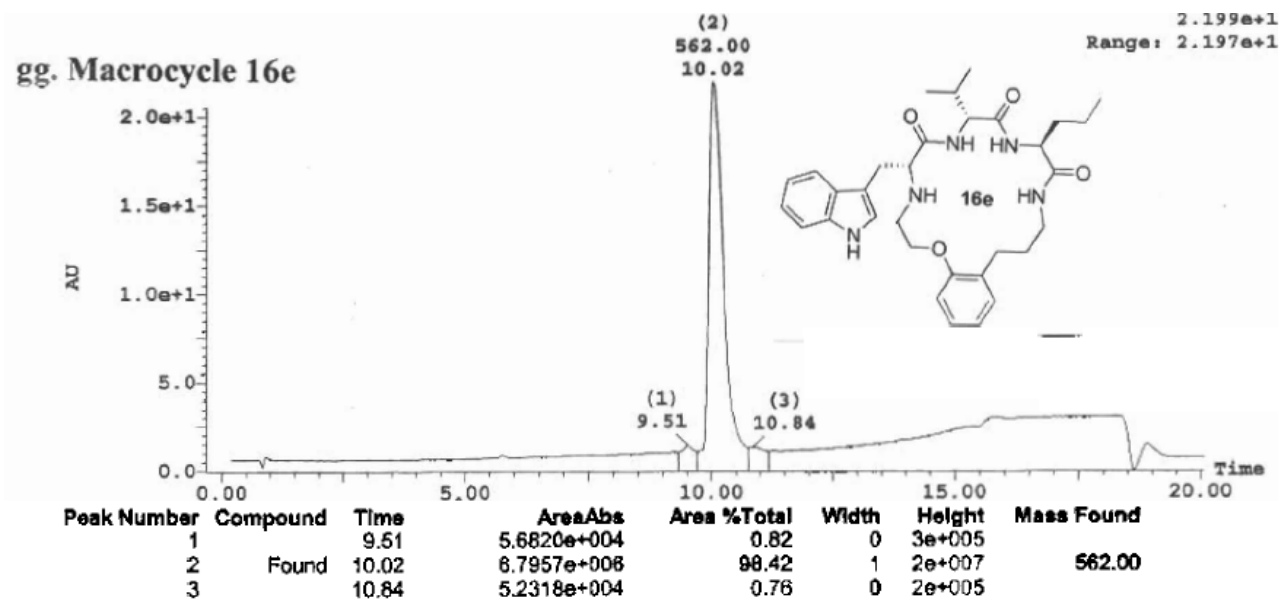

CLND

$(2)$
562.00

$1.00+005$
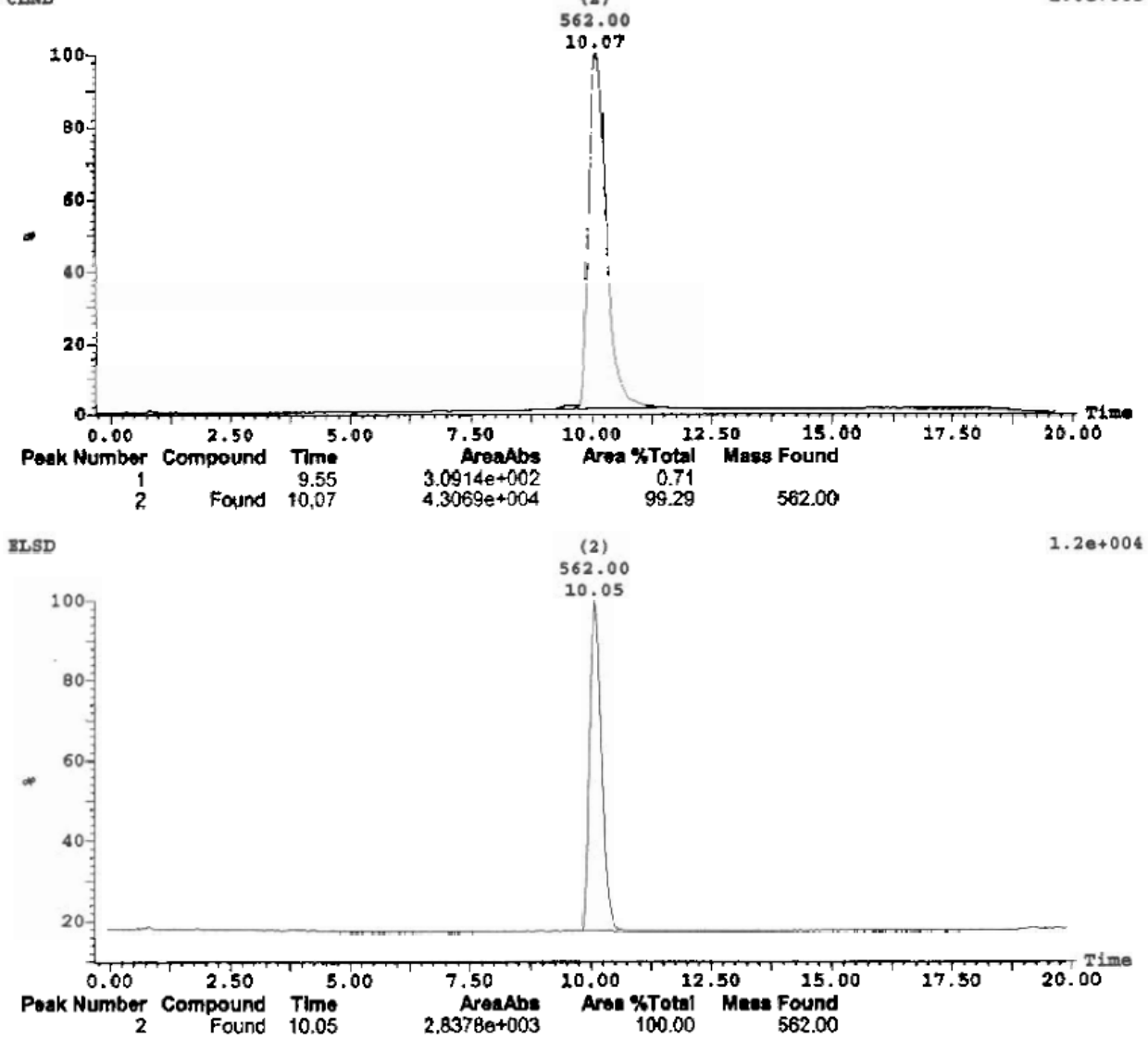

Peak ID $\begin{array}{rr}\text { TIme } \\ 2 & 10.07\end{array}$

2. Combine $\{395: 403\} \quad$ 1:MS AP+

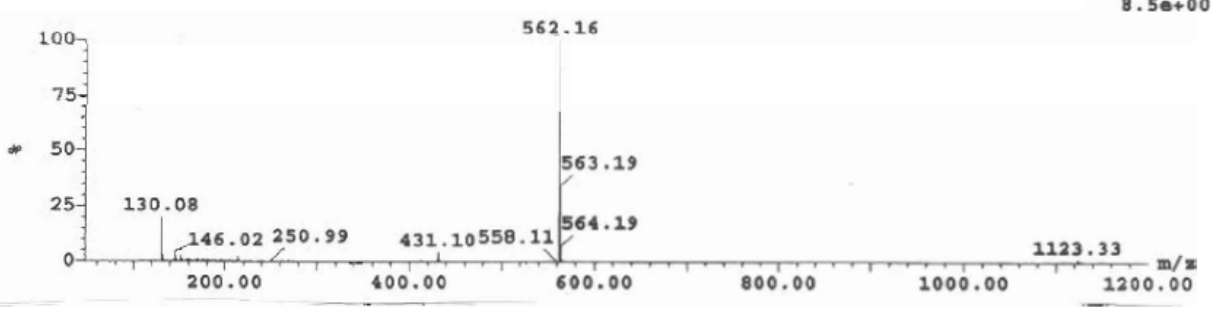


hh. Macrocycle $16 \mathrm{~g}$

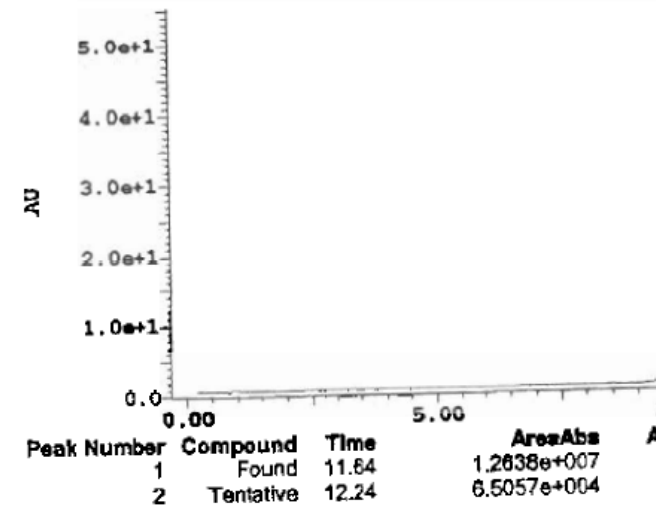

$$
\underset{578.00}{11.64}
$$

CLND

$6.5057 e+004$

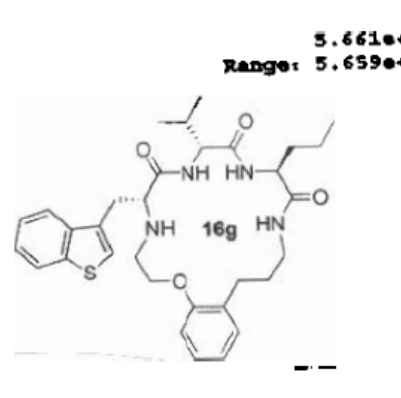

(2)

578.00

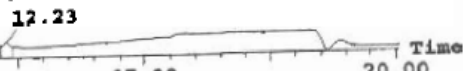

10.00

Woth Holght Mass Found

20.00

$\begin{array}{rrrr}99.49 & 1 & 6 \mathrm{e}+007 & 578.00 \\ 0.51 & 0 & \mathbf{6 e + 0 0 5} & \mathbf{5 7 8 . 0 0}\end{array}$

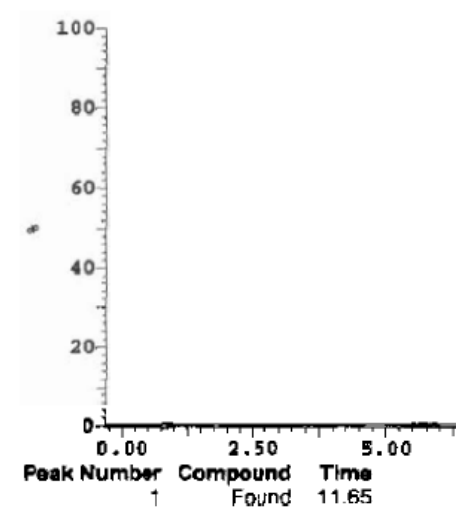

(1)
578.00

$2.2 e+00$ :

11.65

BLSD

pound Time
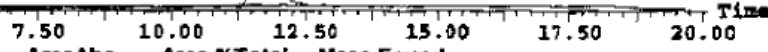
100.00

Found

20.00

100

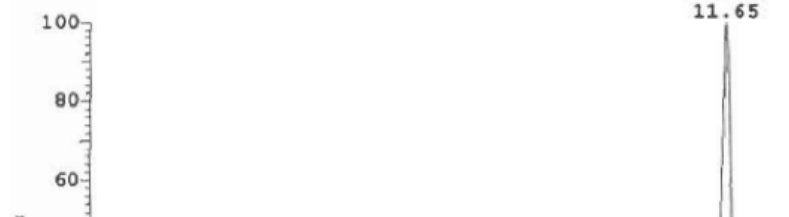

40

4

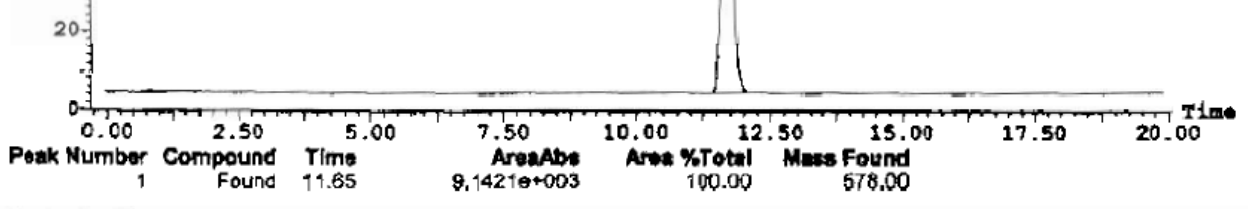

Peak ID Time

1. Comb1ne (461:468)

1:MS AP+

(1)

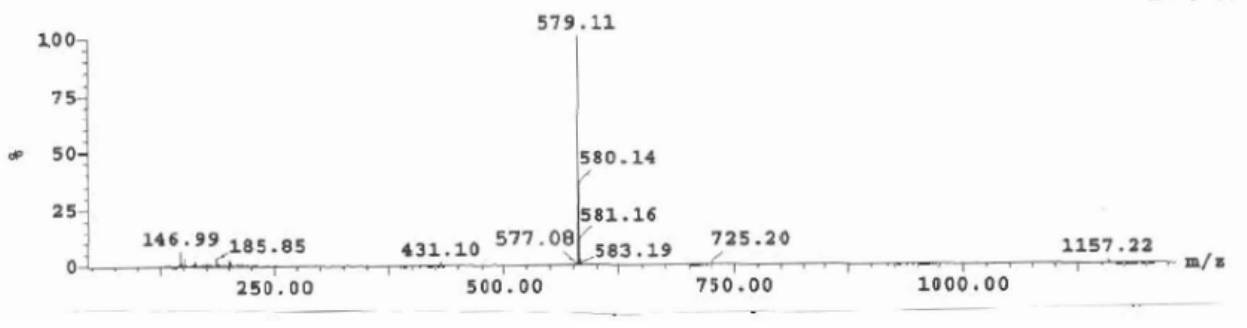


ii. Macrocycle $16 \mathrm{~h}$
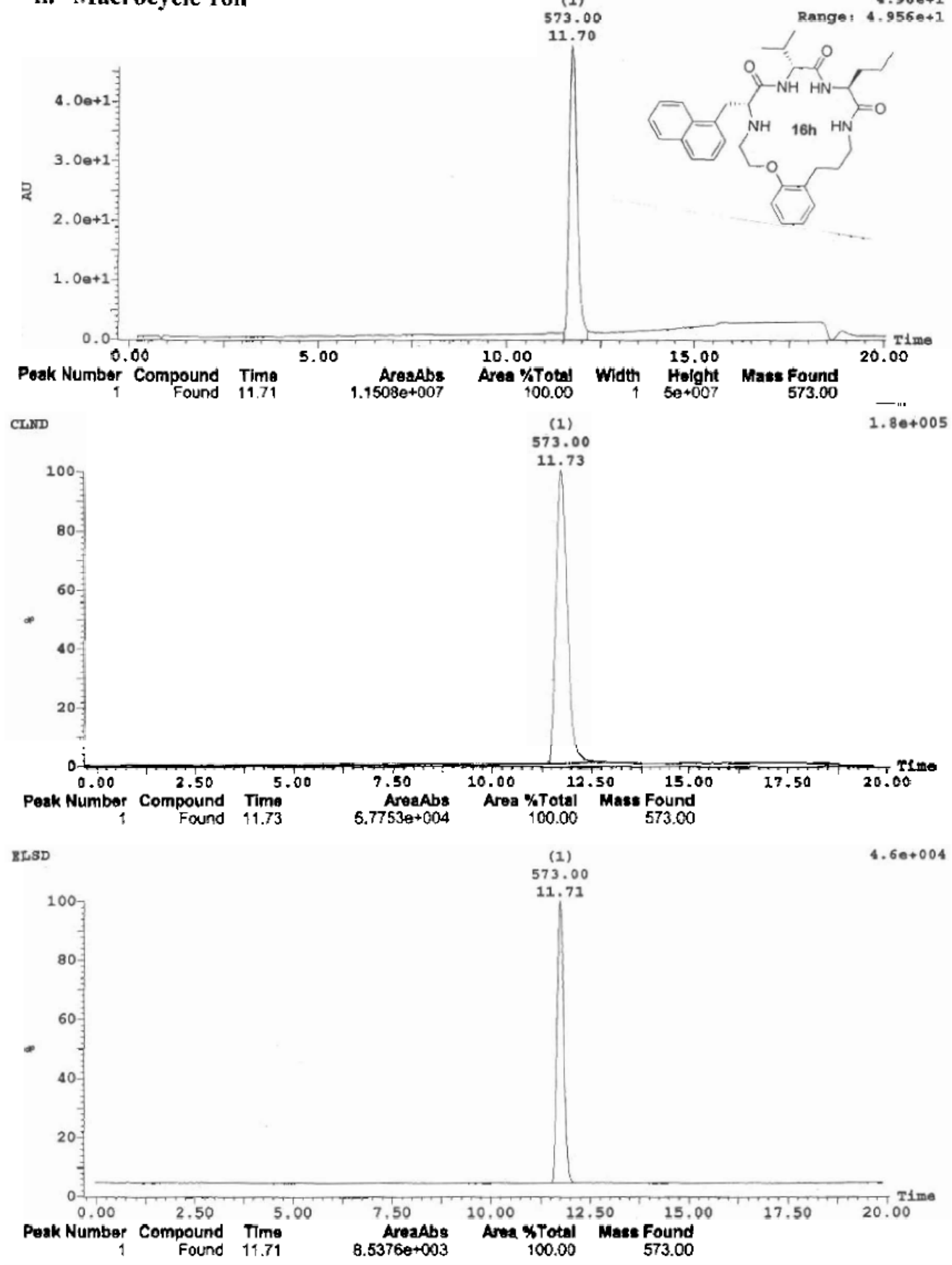

$\begin{array}{rr}\text { Peak ID } & \text { Time } \\ 1 & 11.72\end{array}$

1: Combine $(458,465)$

1. MS AP+

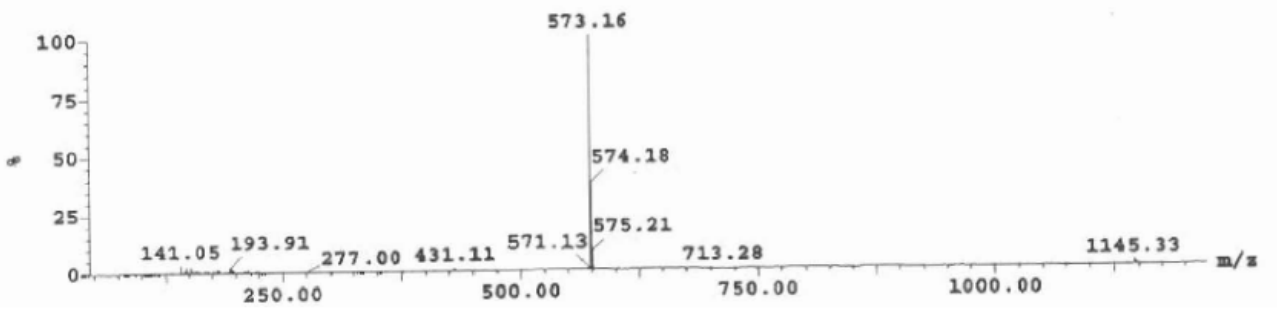


jj. Macrocycle 16i
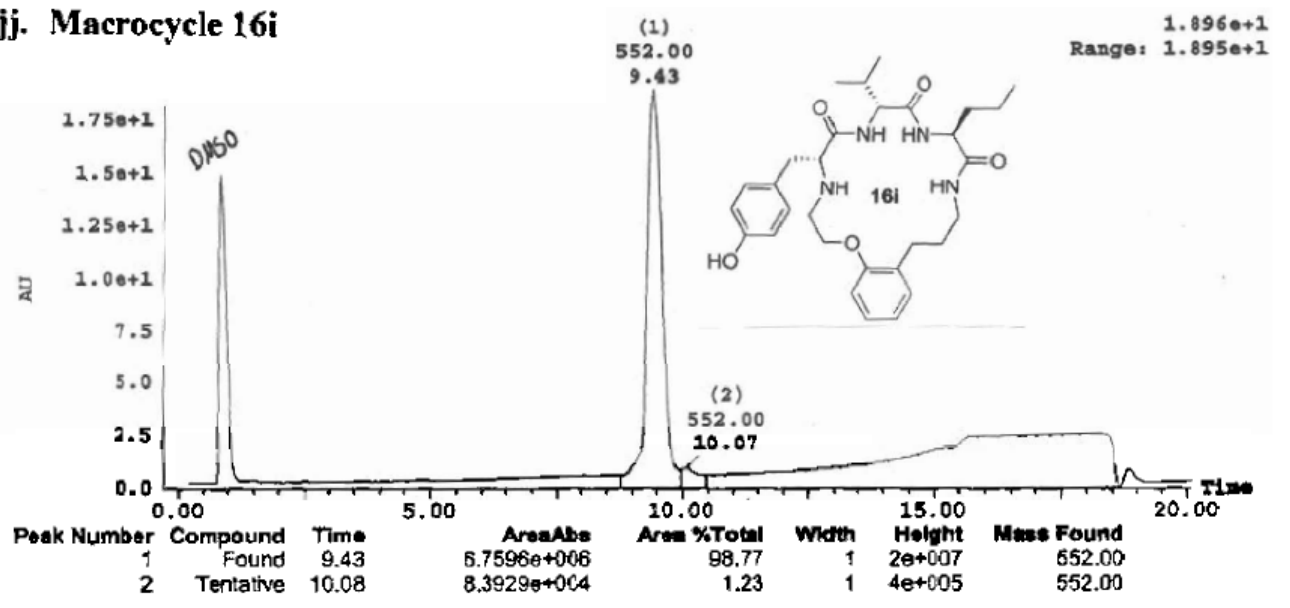

$\stackrel{\substack{(1) \\ 552.00 \\ 9.43}}{40}$

extr

$2.16+009$

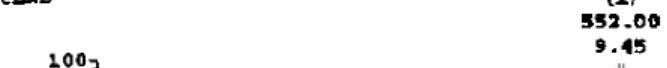

9.45

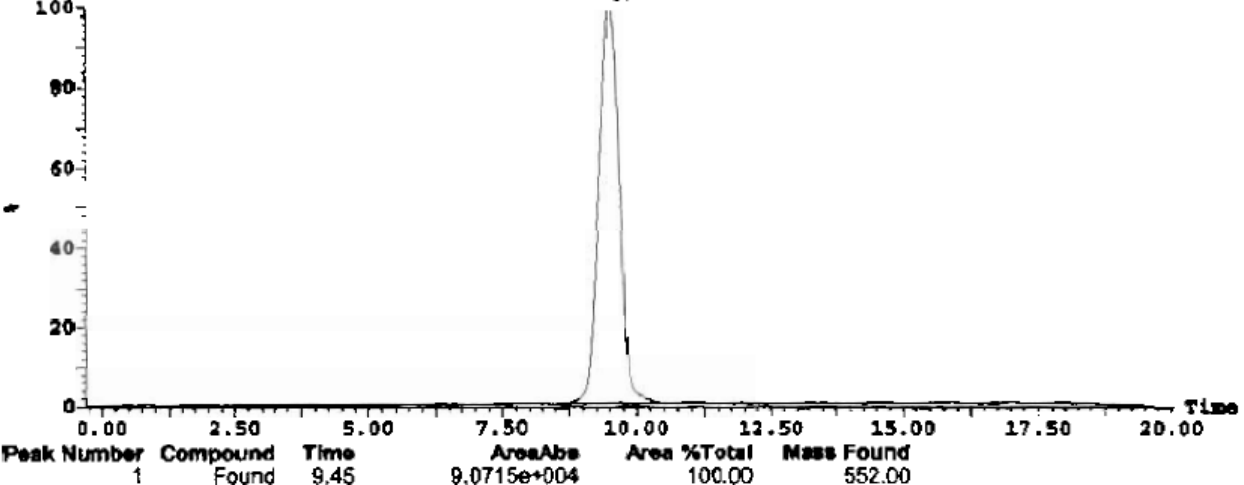

IL8D

Found 9.45

9.0715 e+004

$2.70+004$

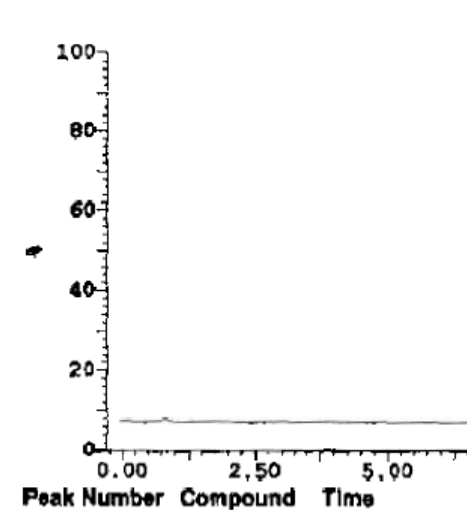

(1)
552.00

100.00

552.00

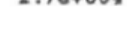

Found Time

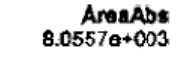

9.45

$\begin{array}{rr}\text { Peak ID } & \text { Time } \\ \mathbf{9 . 4 3}\end{array}$

1. Combine $(360: 368)$

1. MS AP+

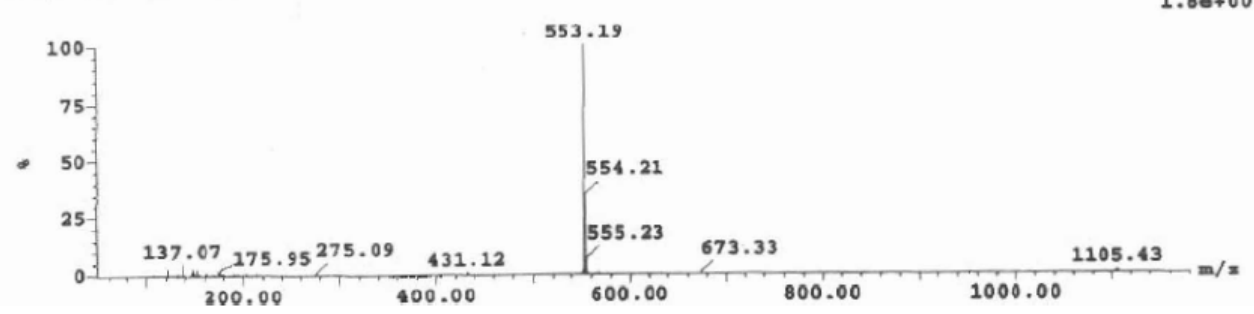




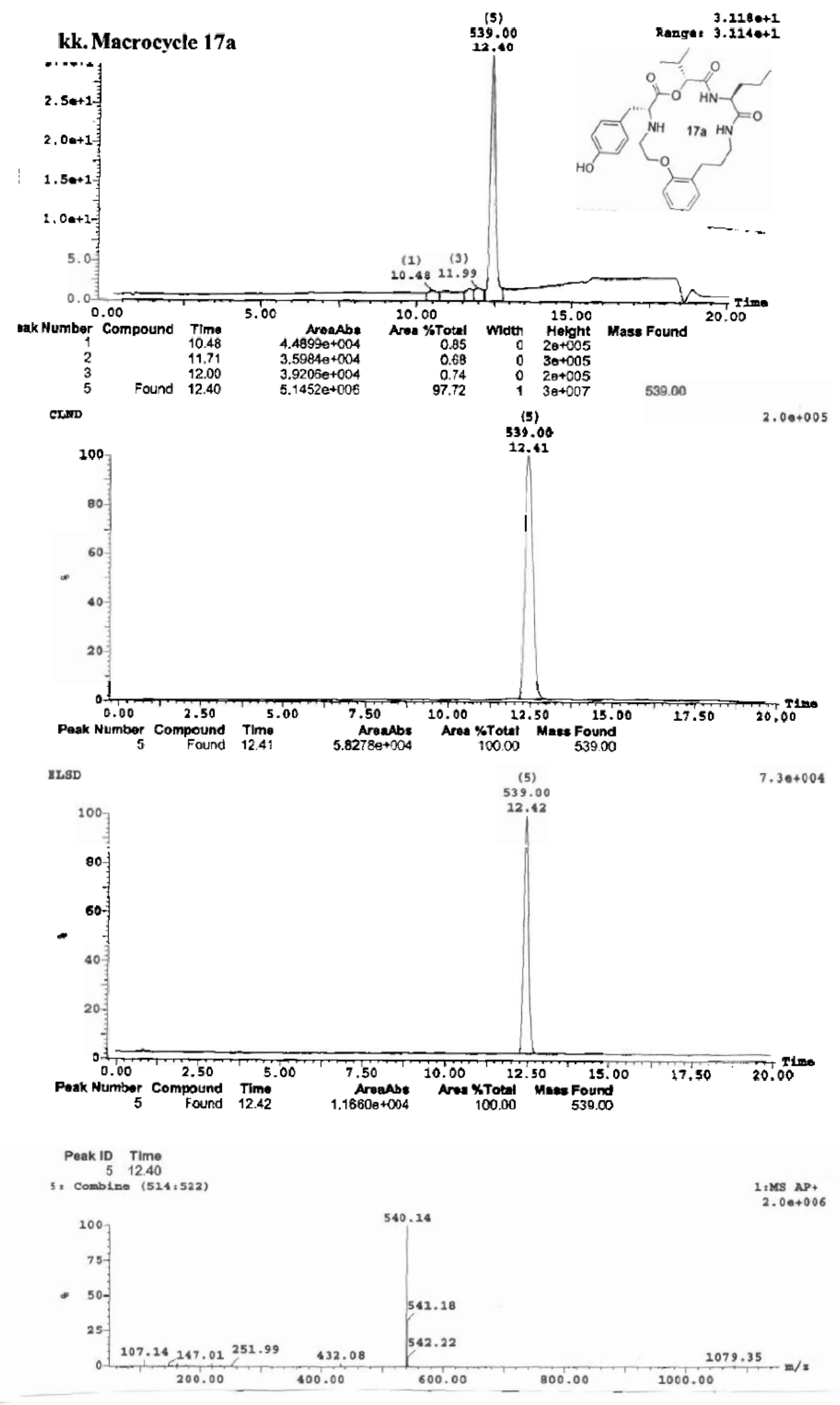


II. Macrocycle 17b
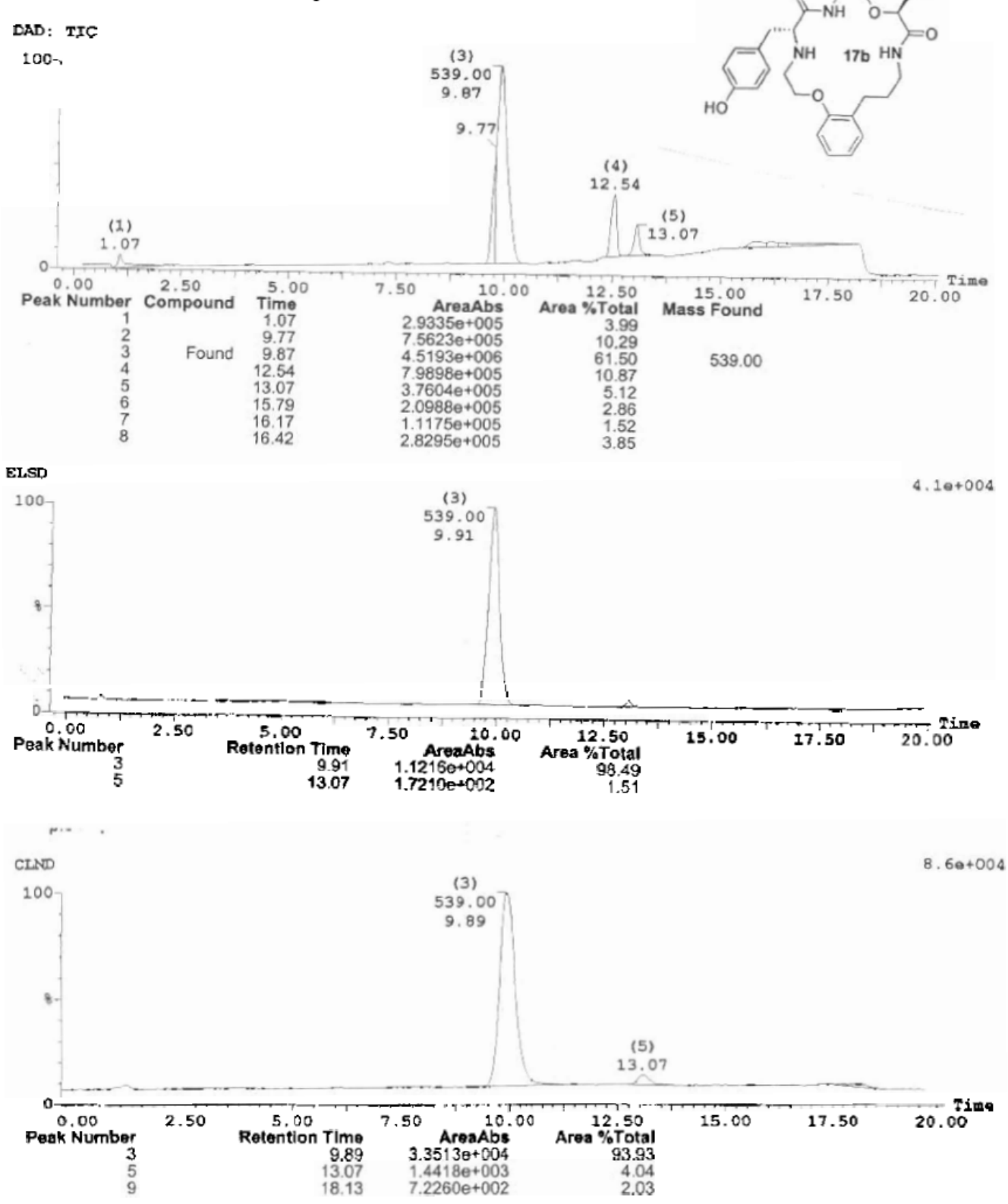

Poak ID $\quad$ Retention Time

Coxbine (455:462-(429:434+523:527)) $1:$ MS AP+

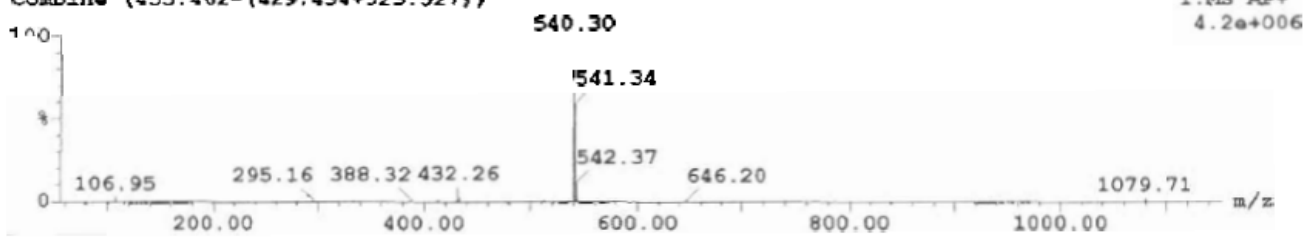


mm. Macrocvcle 17c

2, UV Detector: TIC

(2)

$2.4840+1$

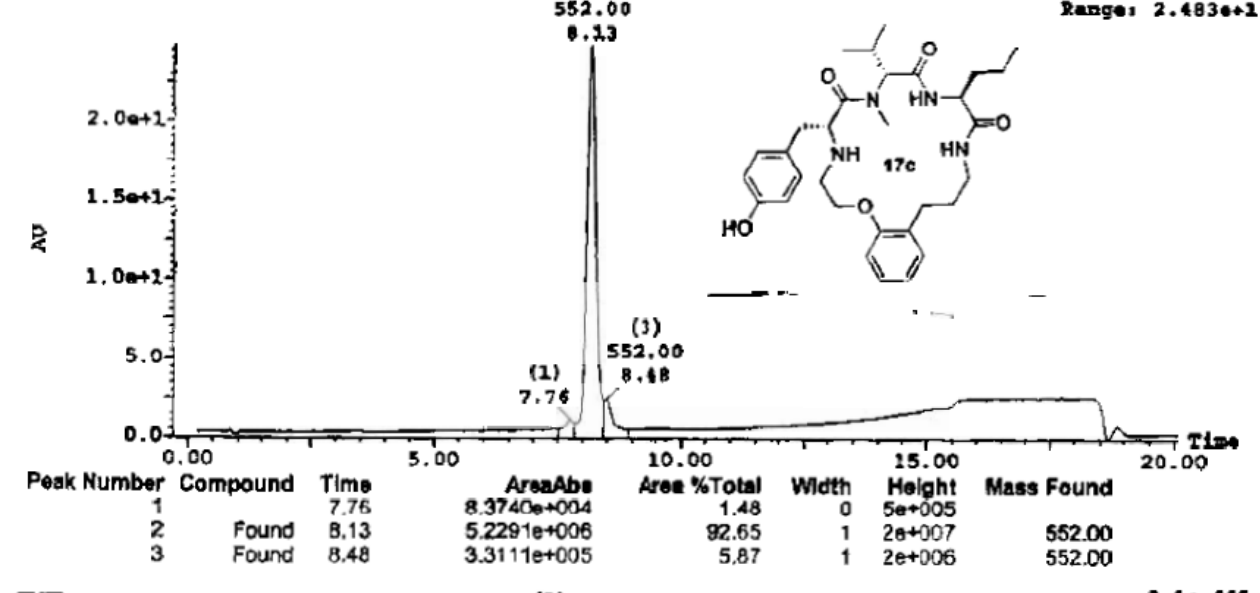

CXID

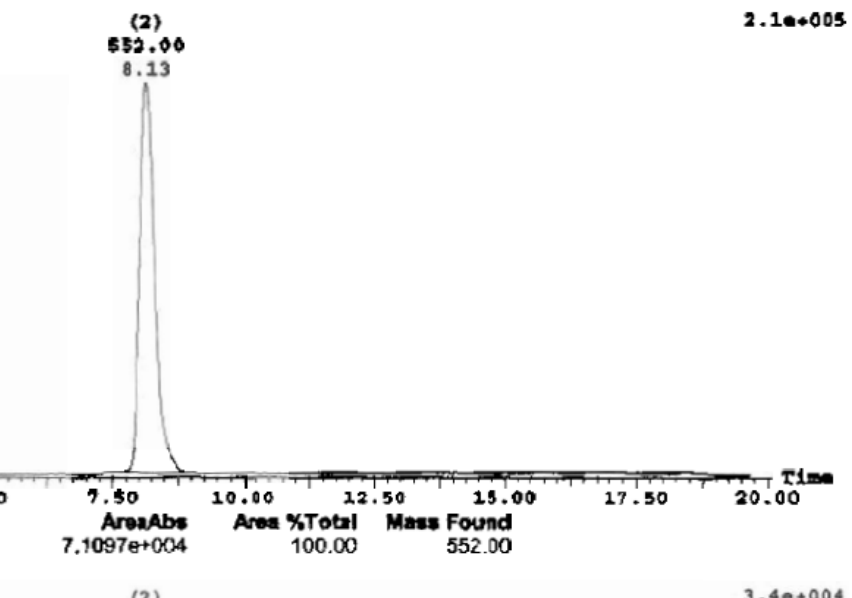

$2.10+005$

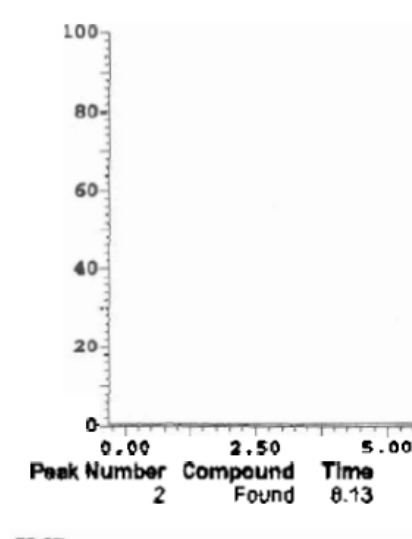

552.00
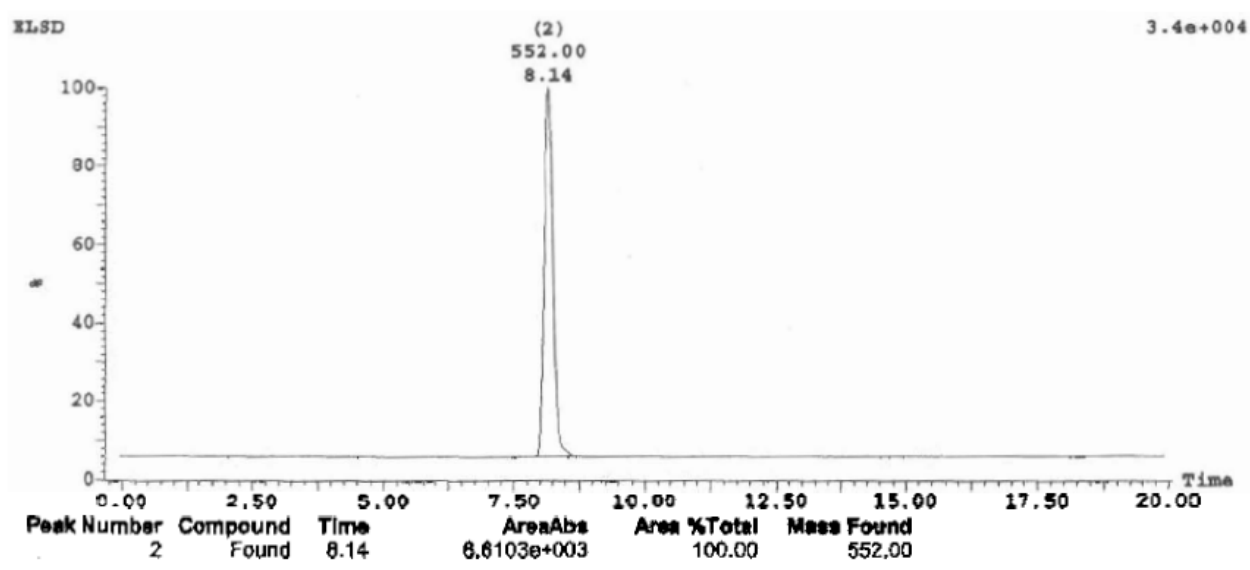

Peak ID Time

2. Combine $(316,323)$

$1.7 \bullet+006$

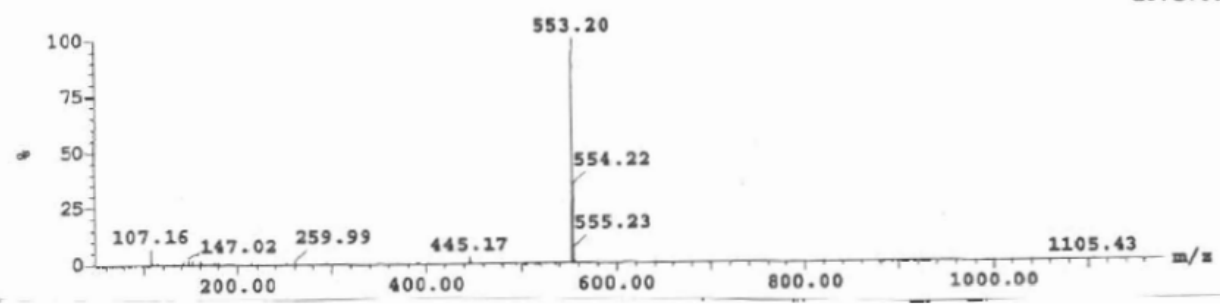


nn. Macrocycle 17d
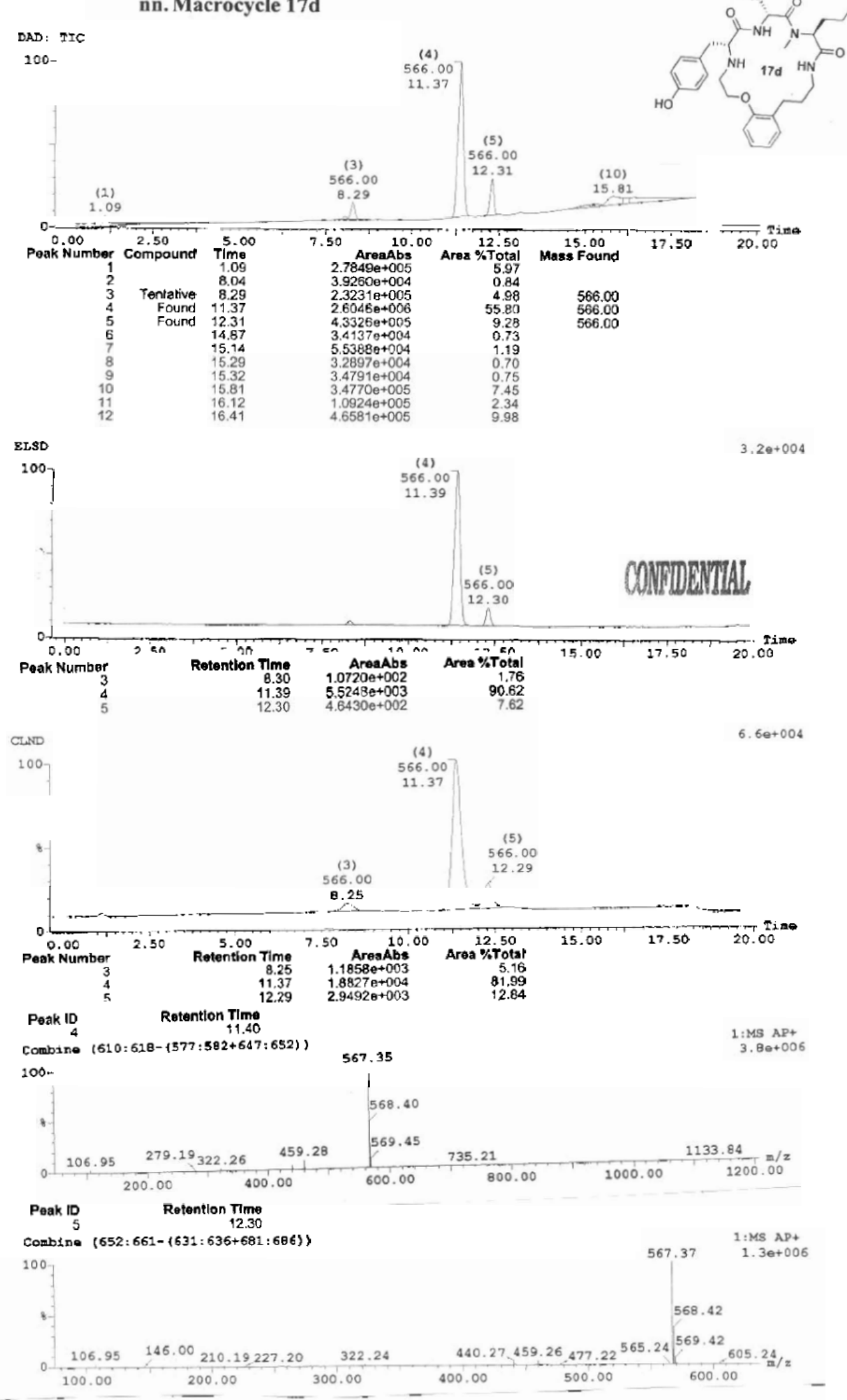


\section{oo. Macrocycle 17e}
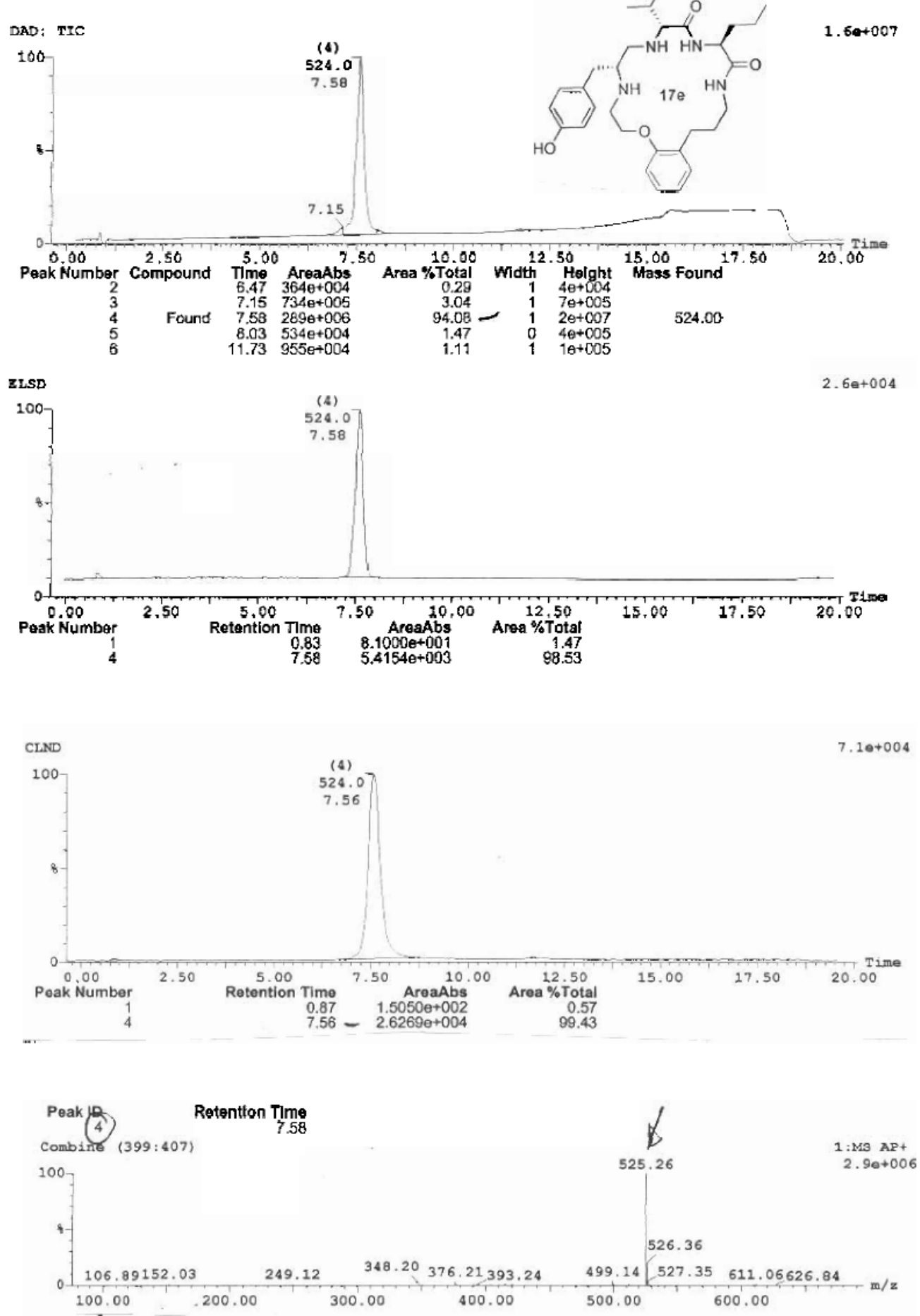


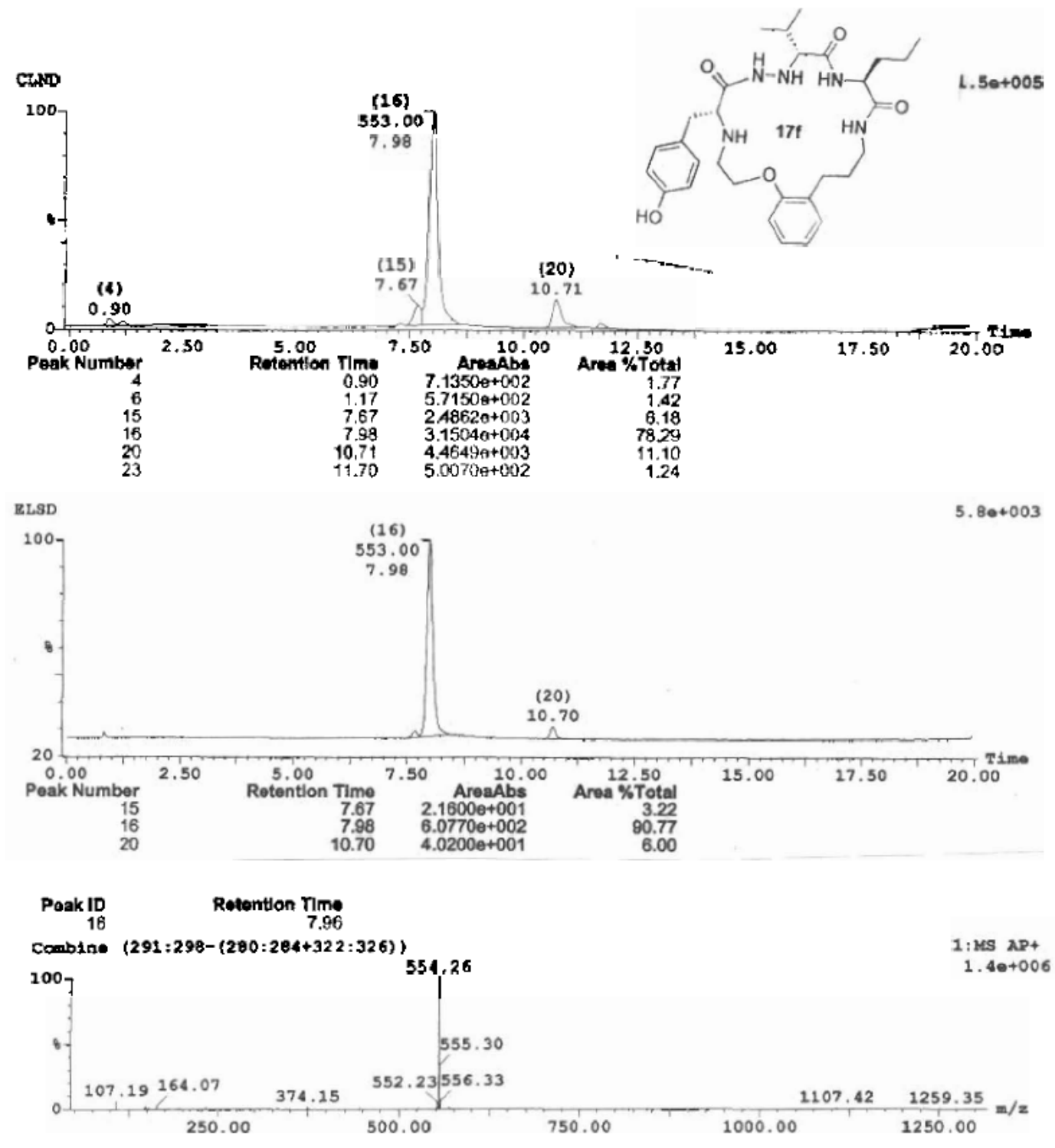


pp. Macrocycle 17g
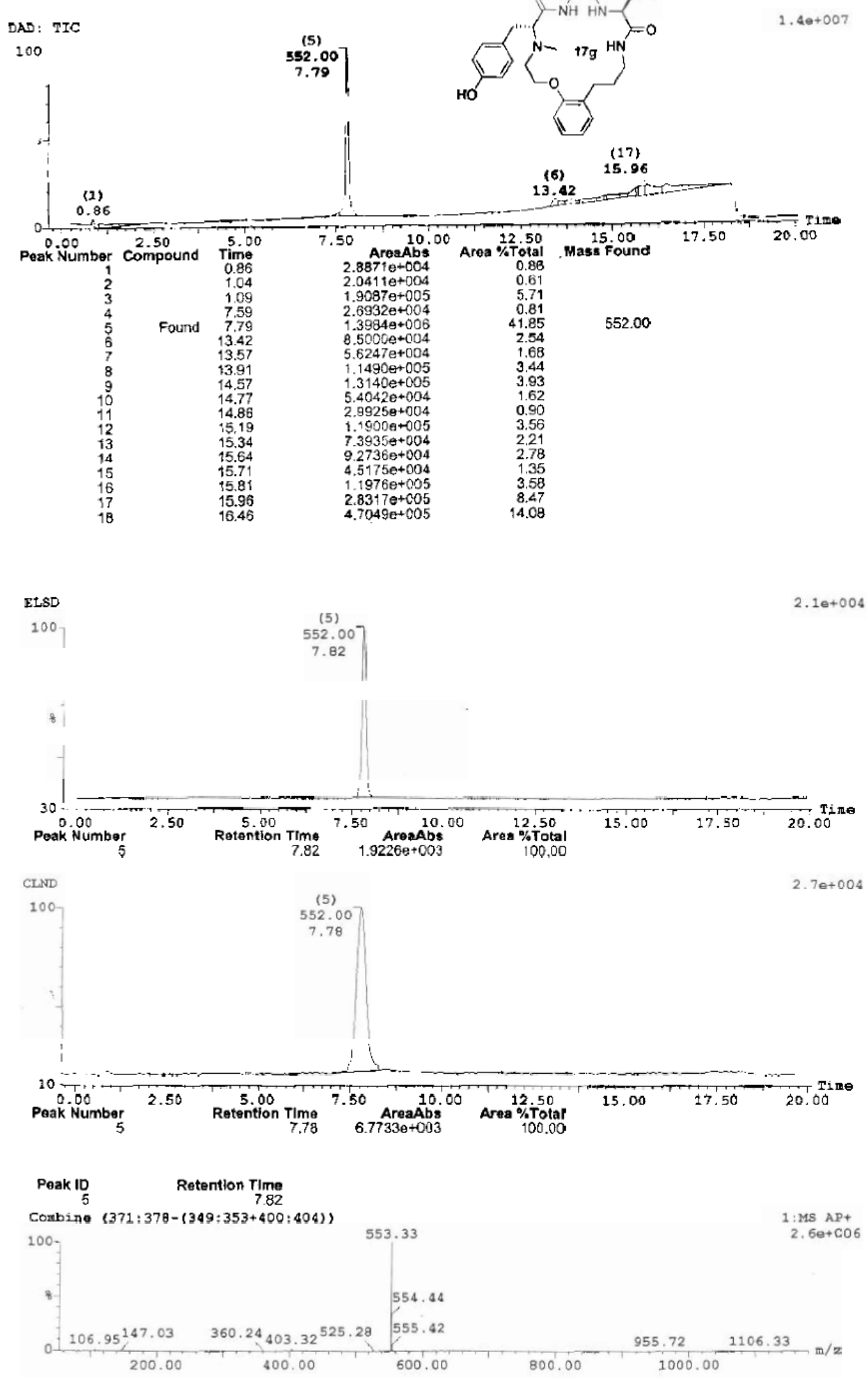
Appendix 3. ${ }^{1} \mathrm{H}$ and ${ }^{13} \mathrm{C}$ NMR spectra of selected final macrocycles a. Macrocycle 1
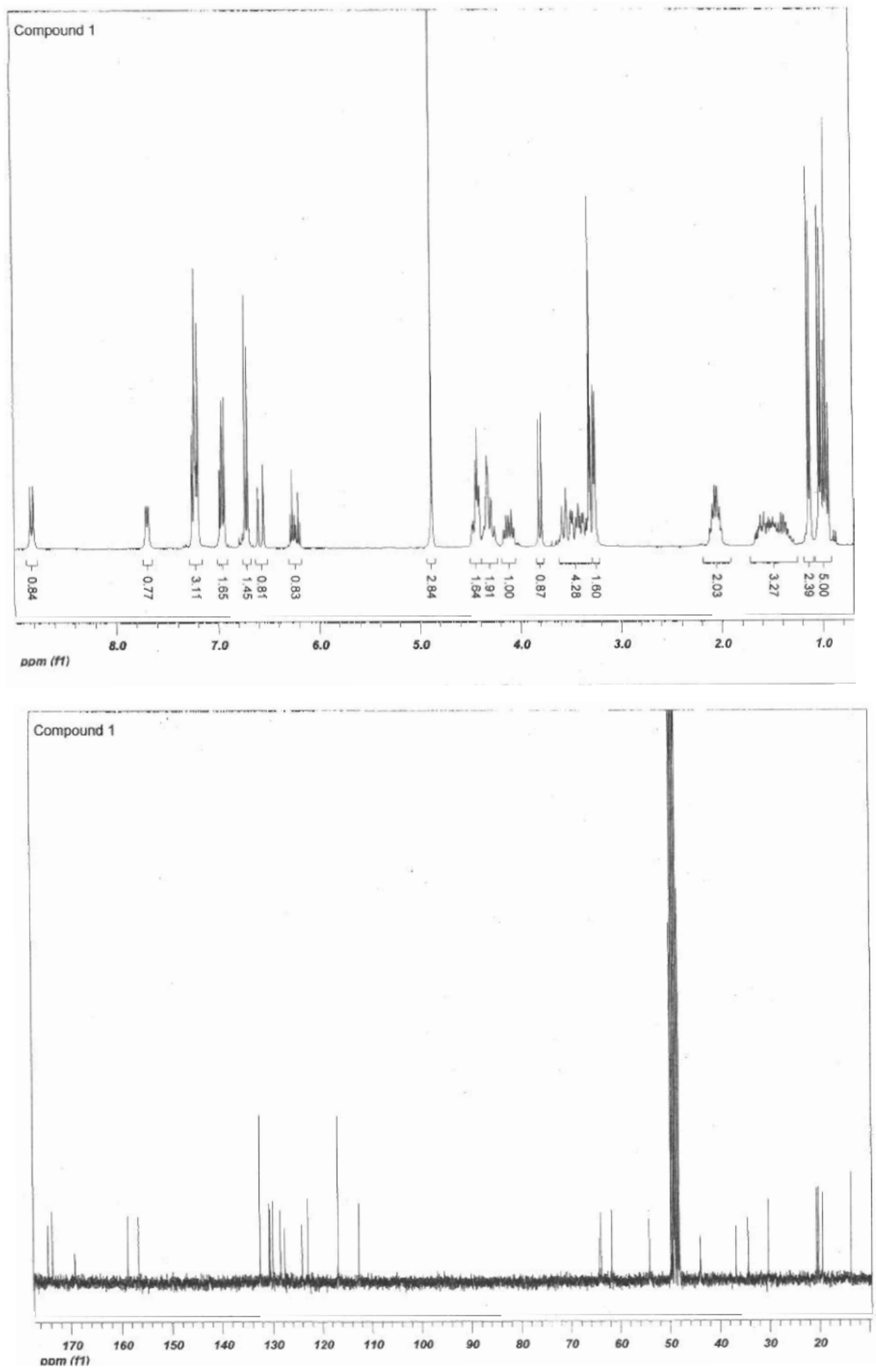
b. Macrocycle 12f
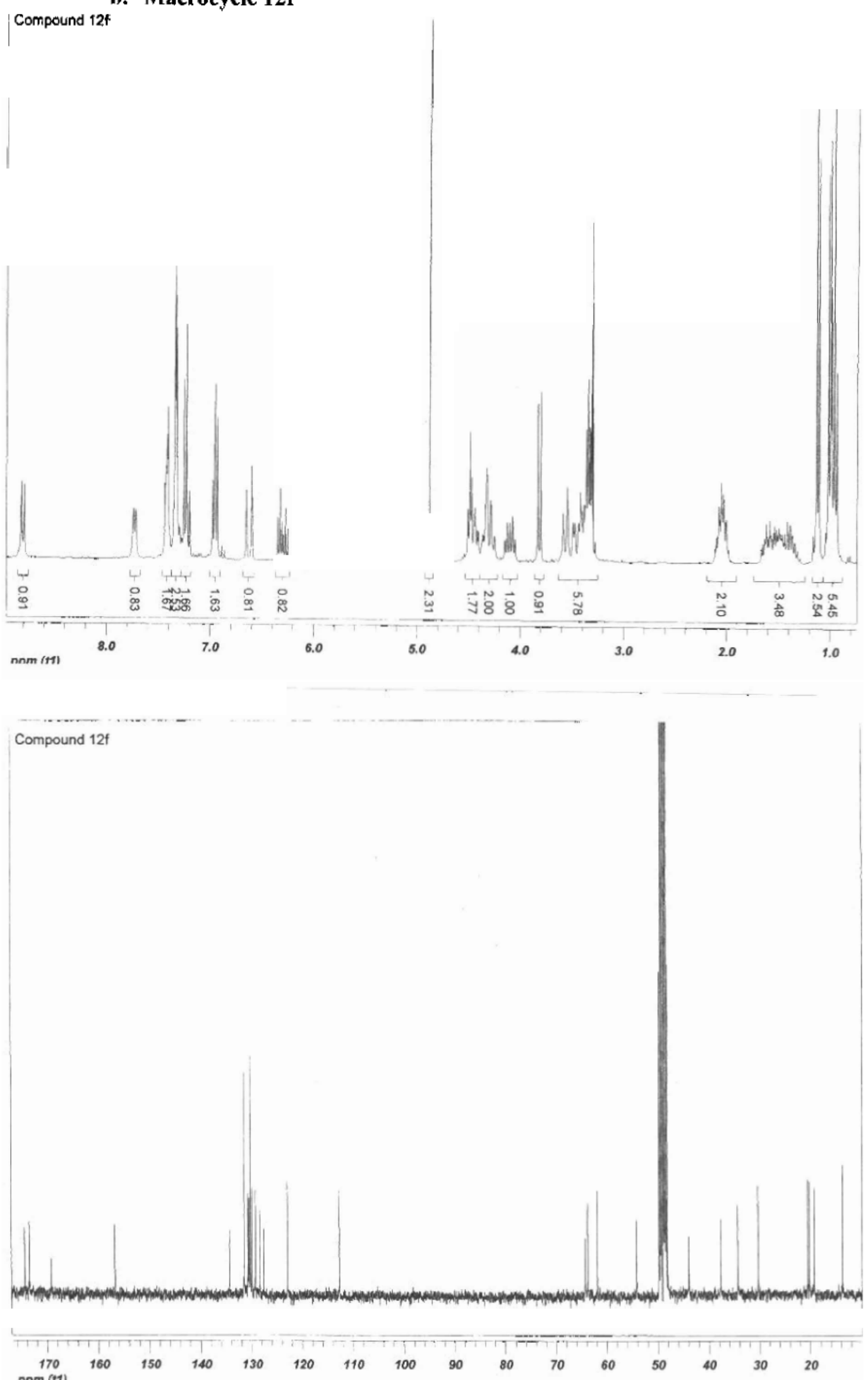


\section{c. Macrocycle 12t}
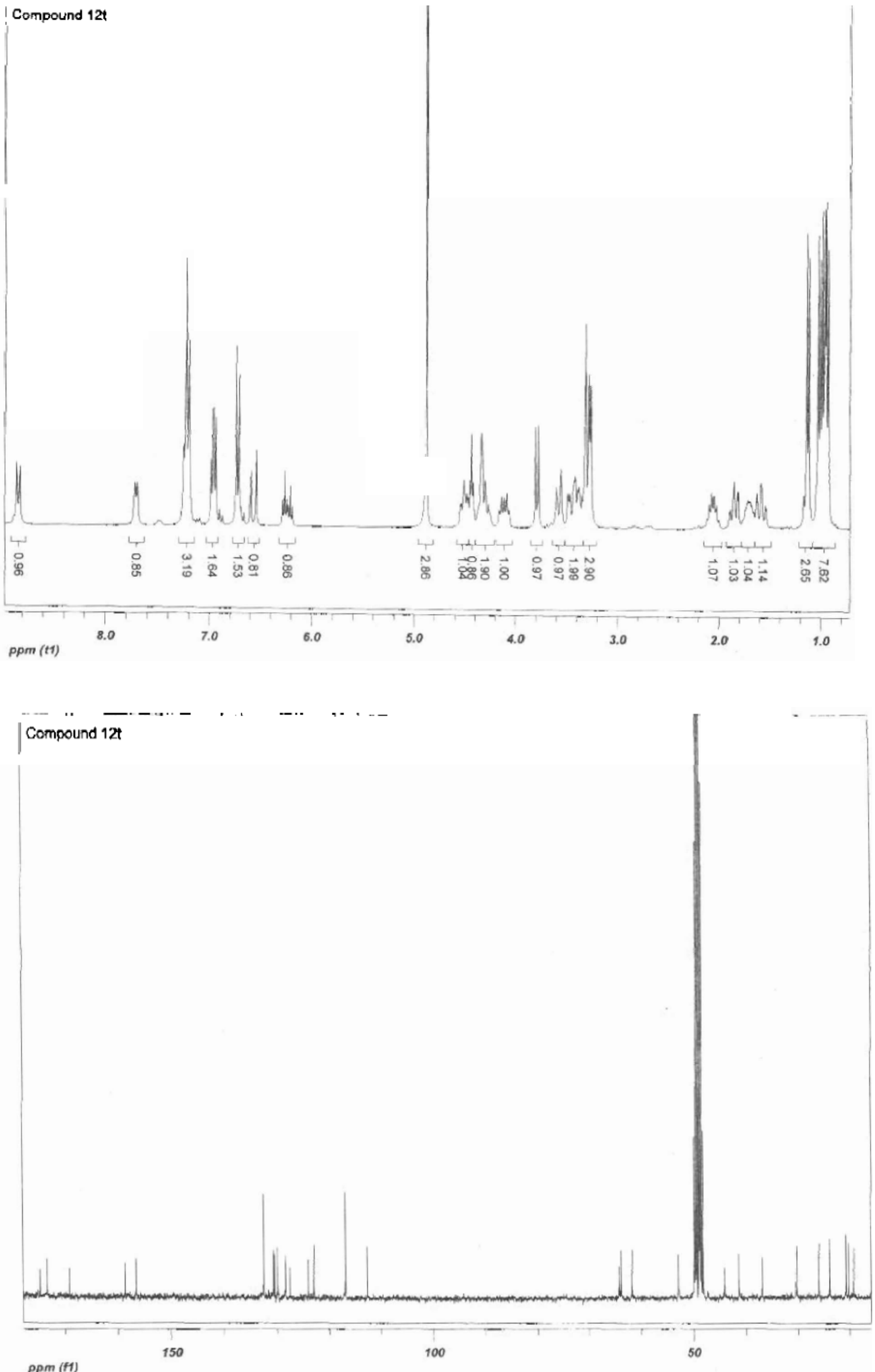


\section{d. Macrocycle 14a}
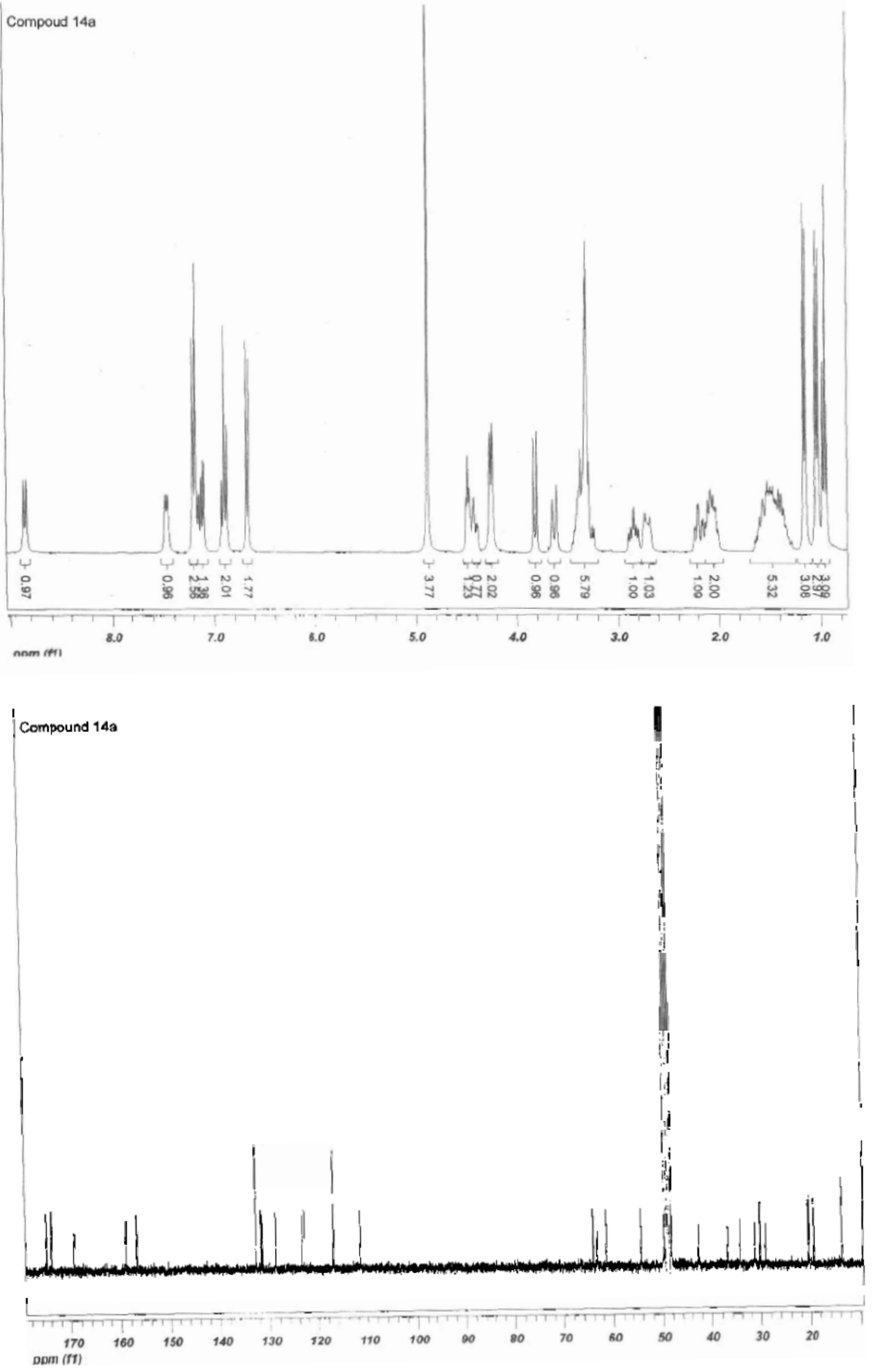


\section{e. Macrocycle 14c}
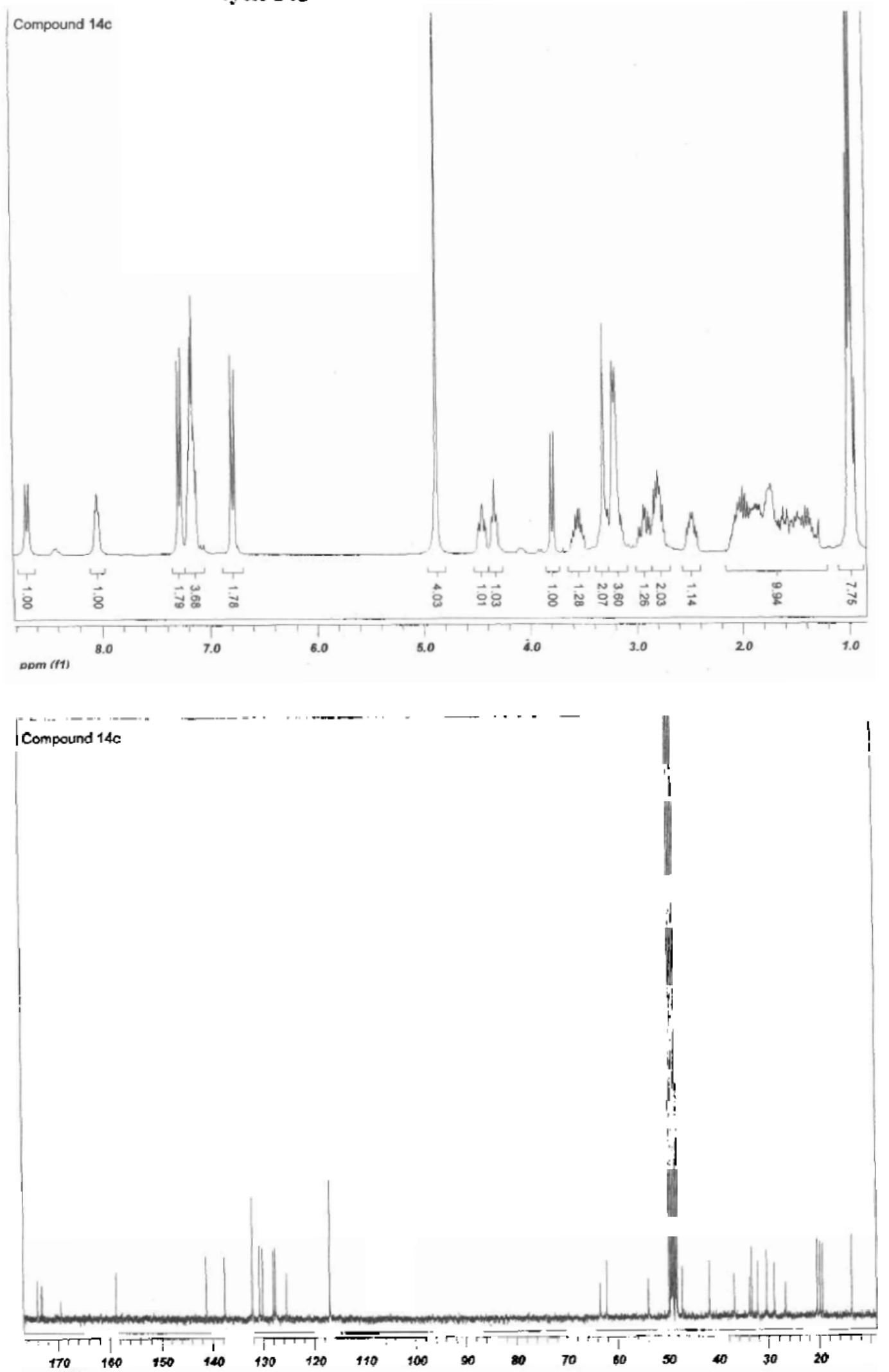
f. Macrocycle 16b
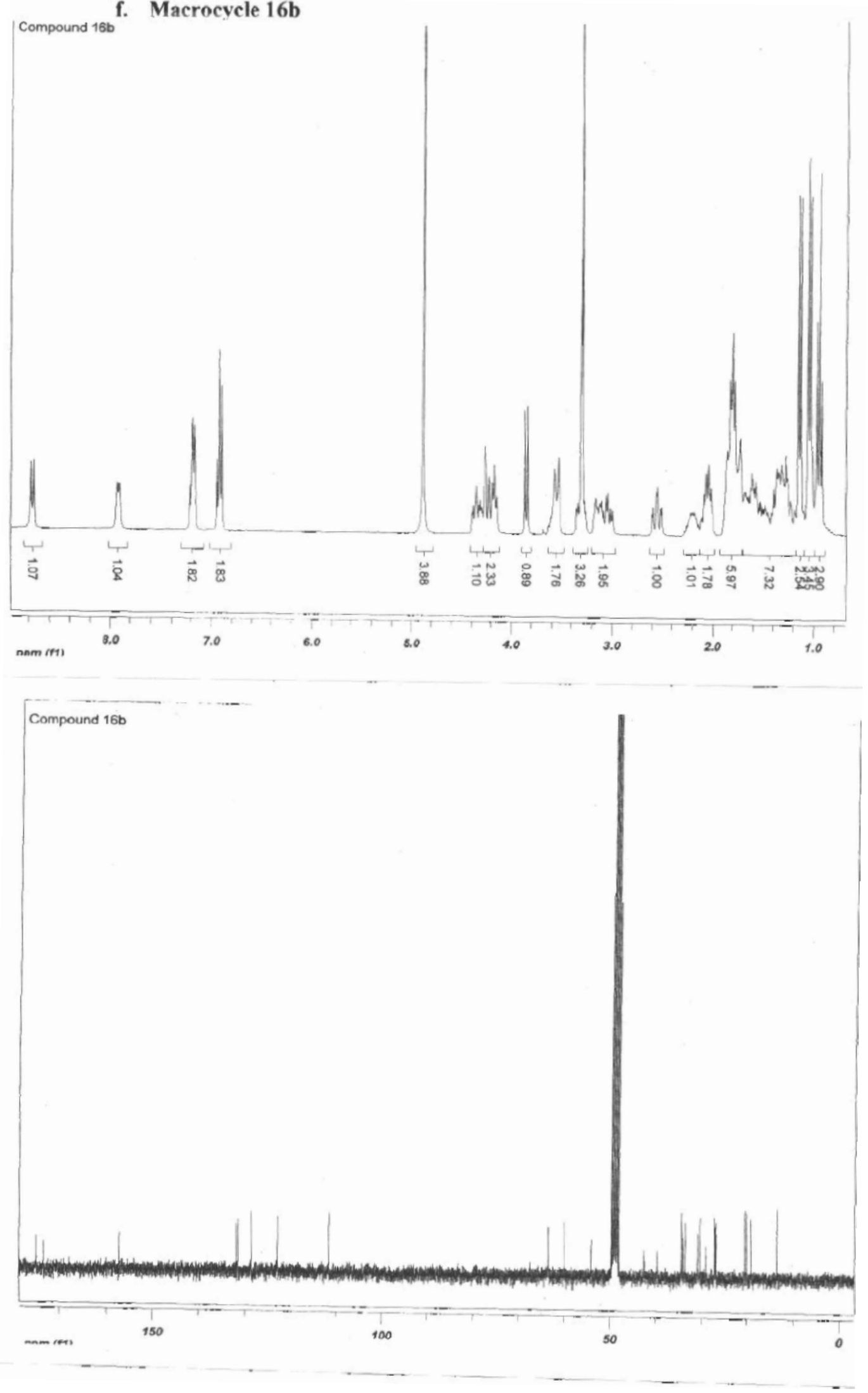
g. Macrocycle 16e
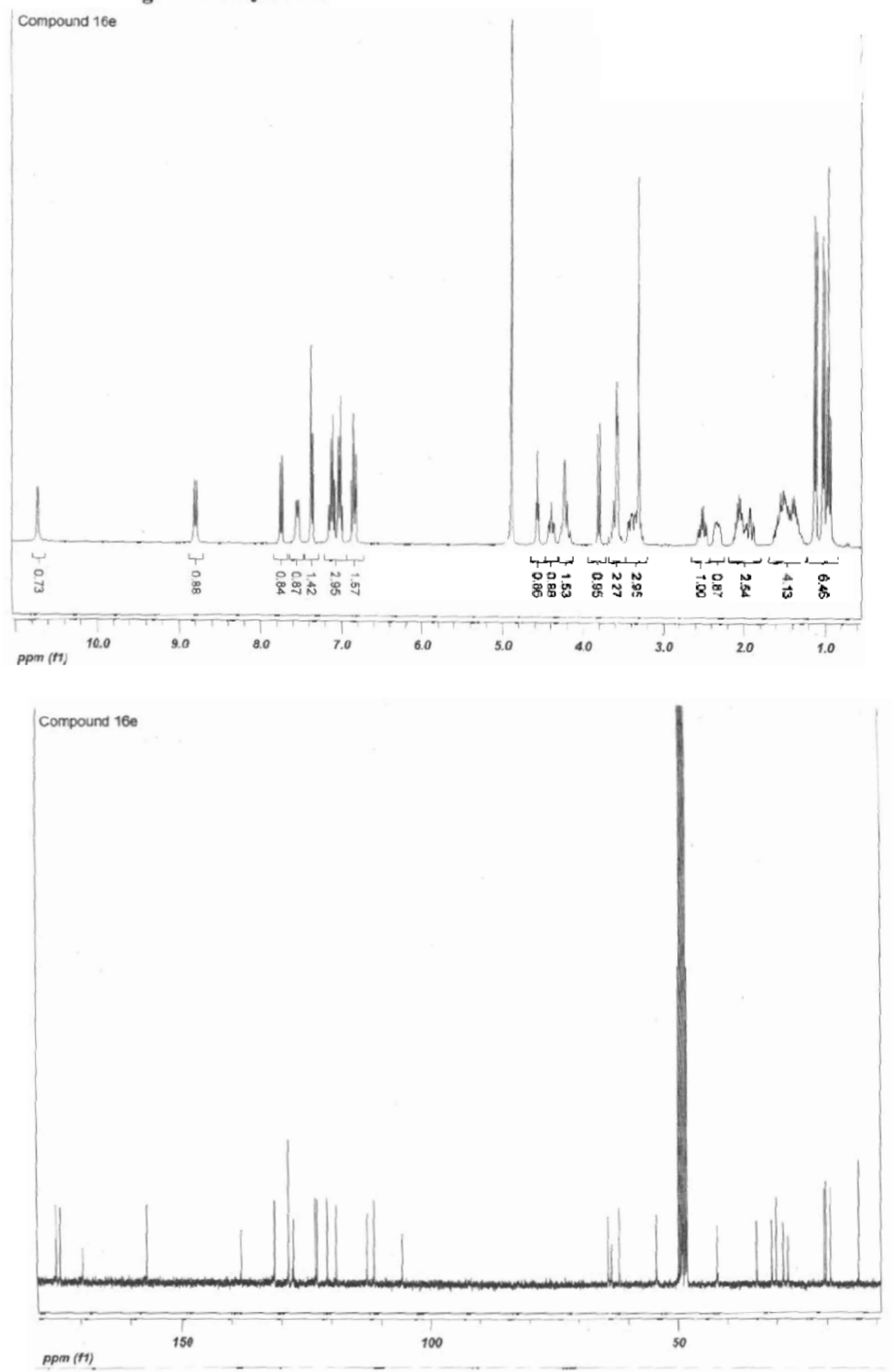
h. Macrocycle 16g

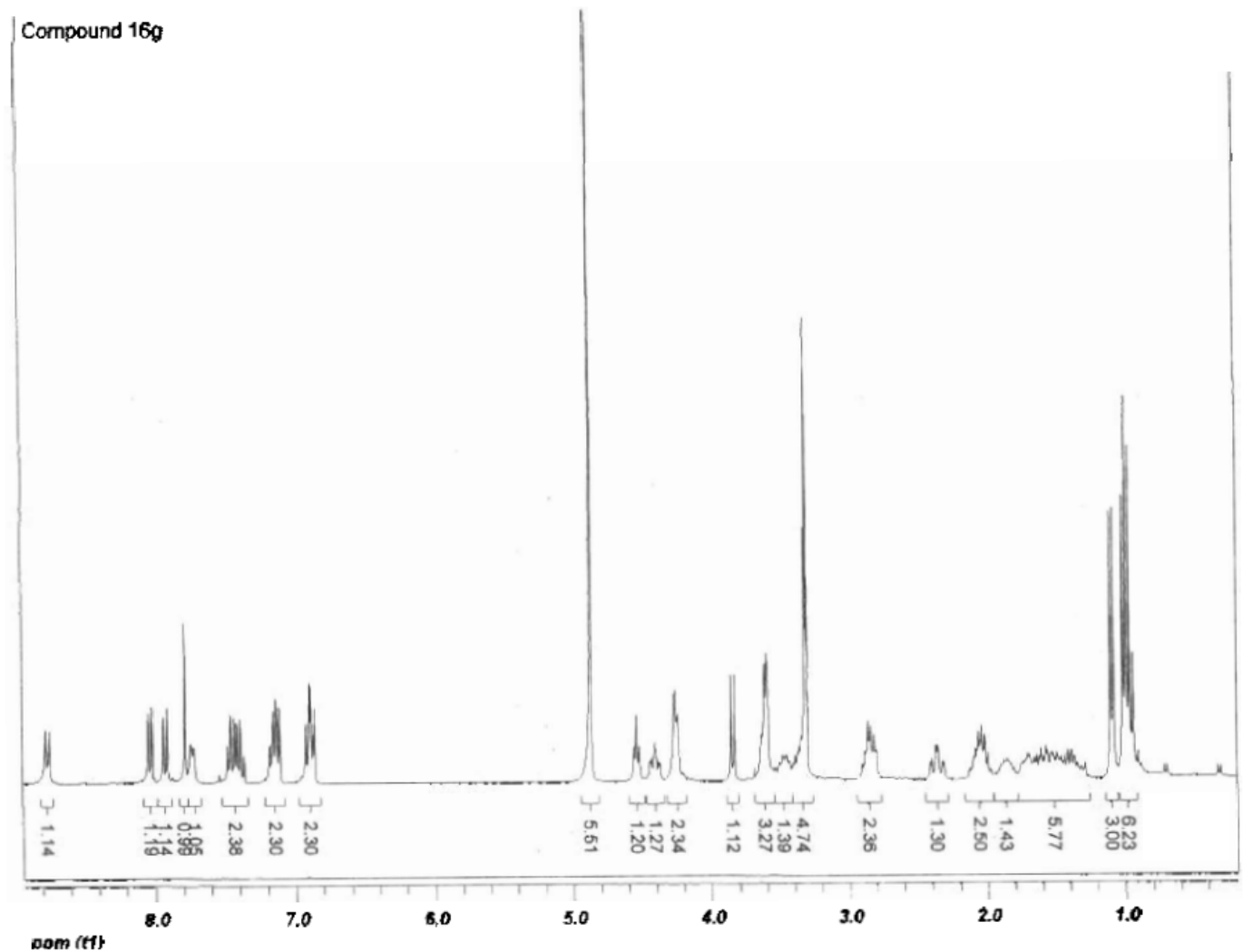

Dom (t)

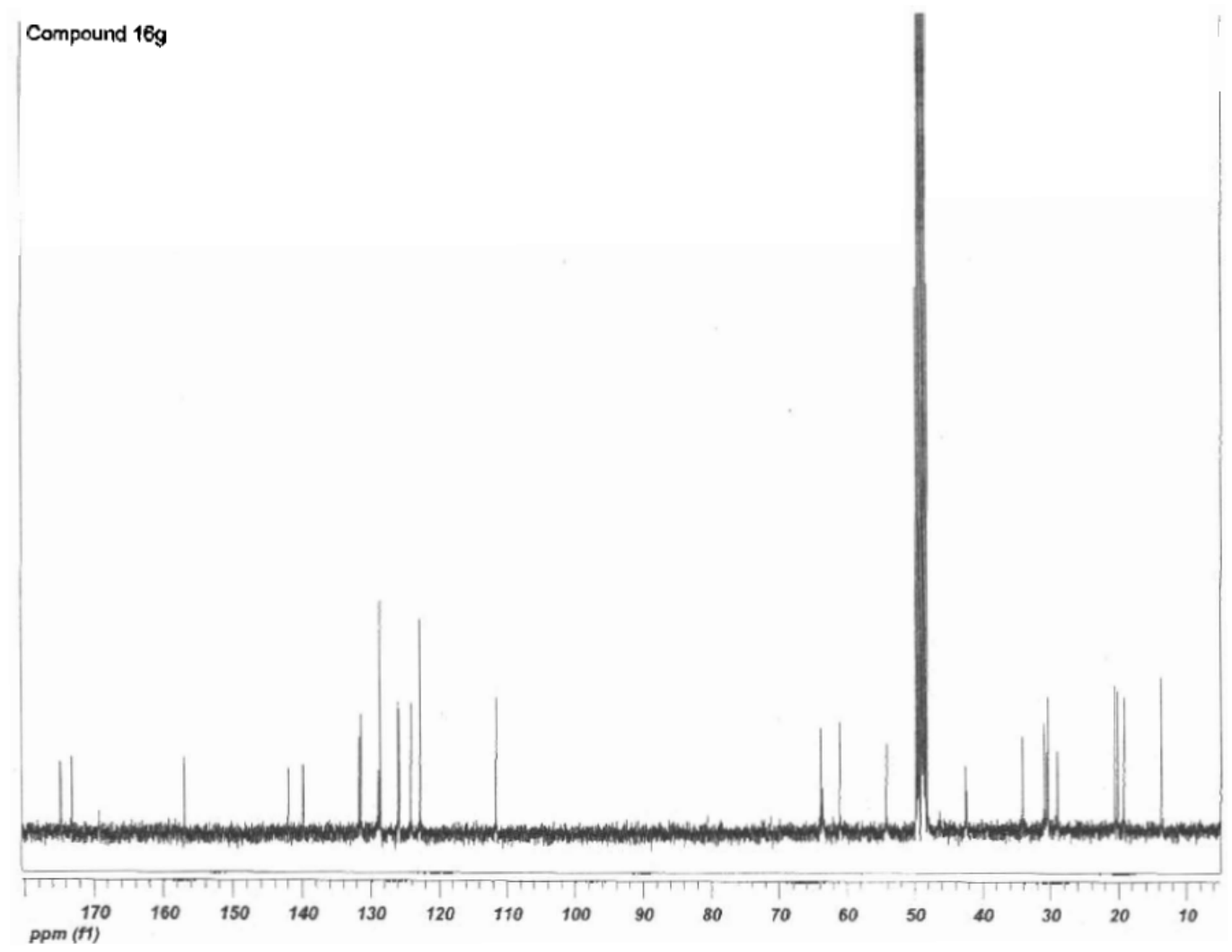



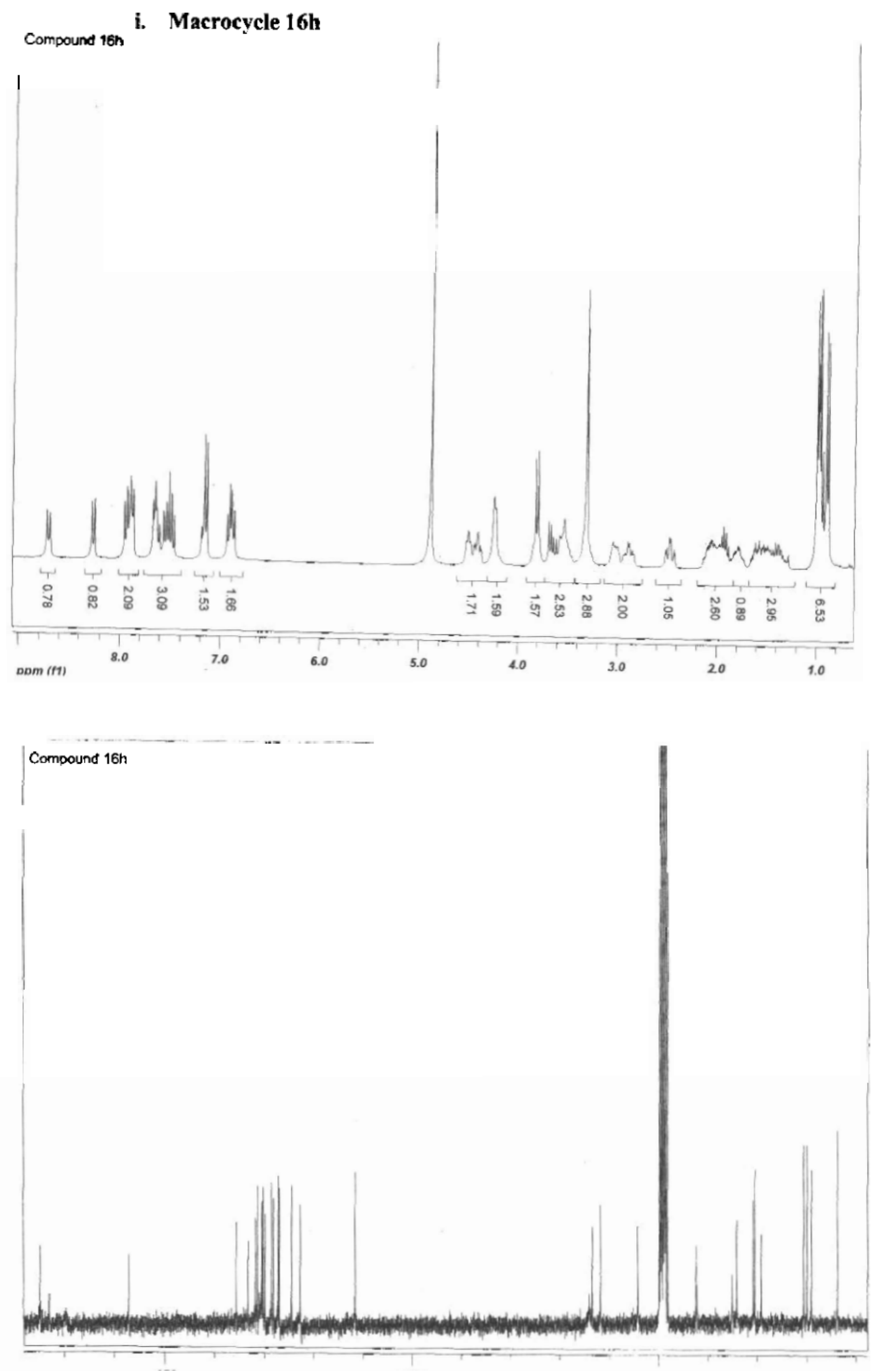


\section{j. Macrocycle 16i}

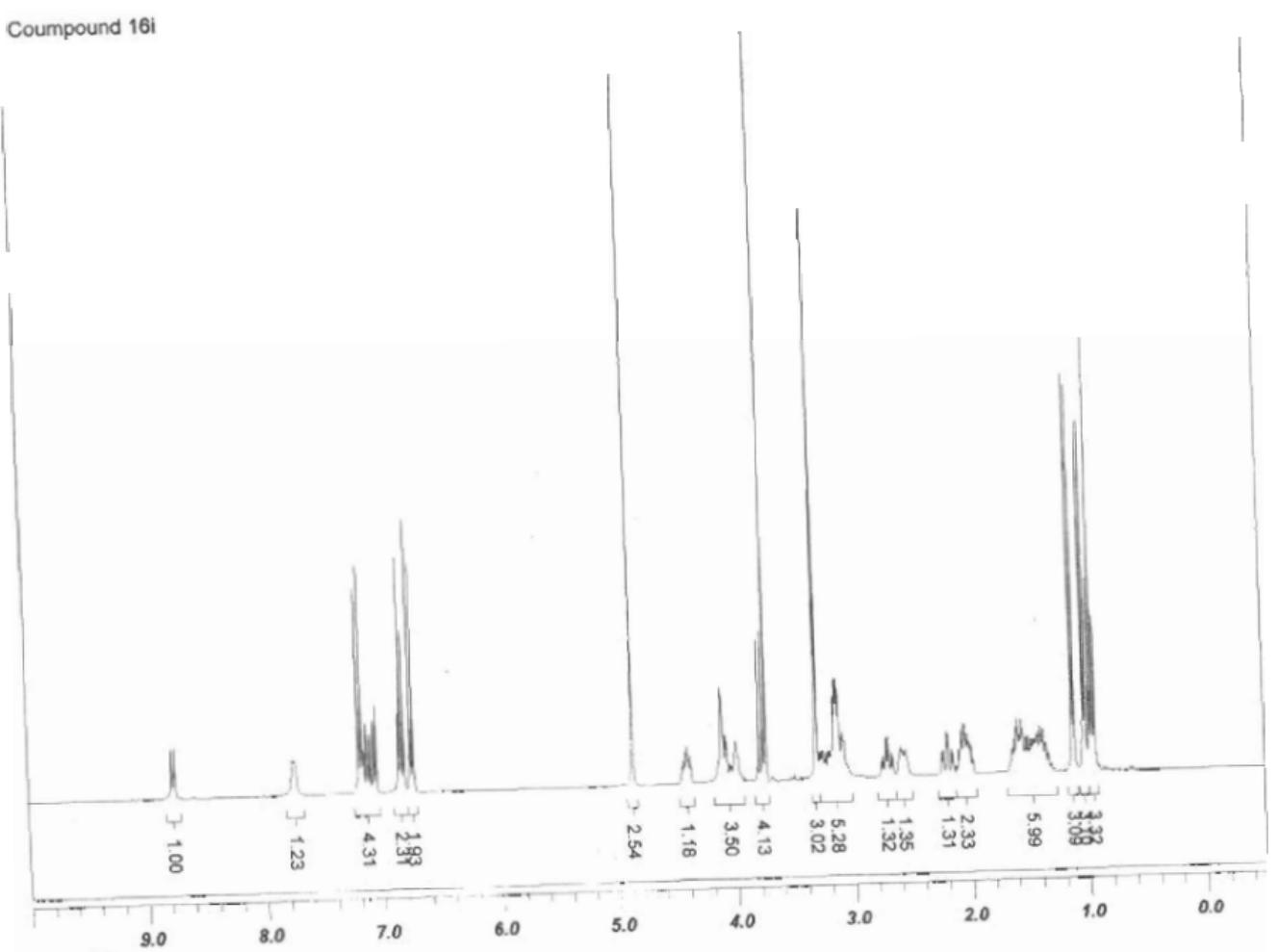

ppm (tt)

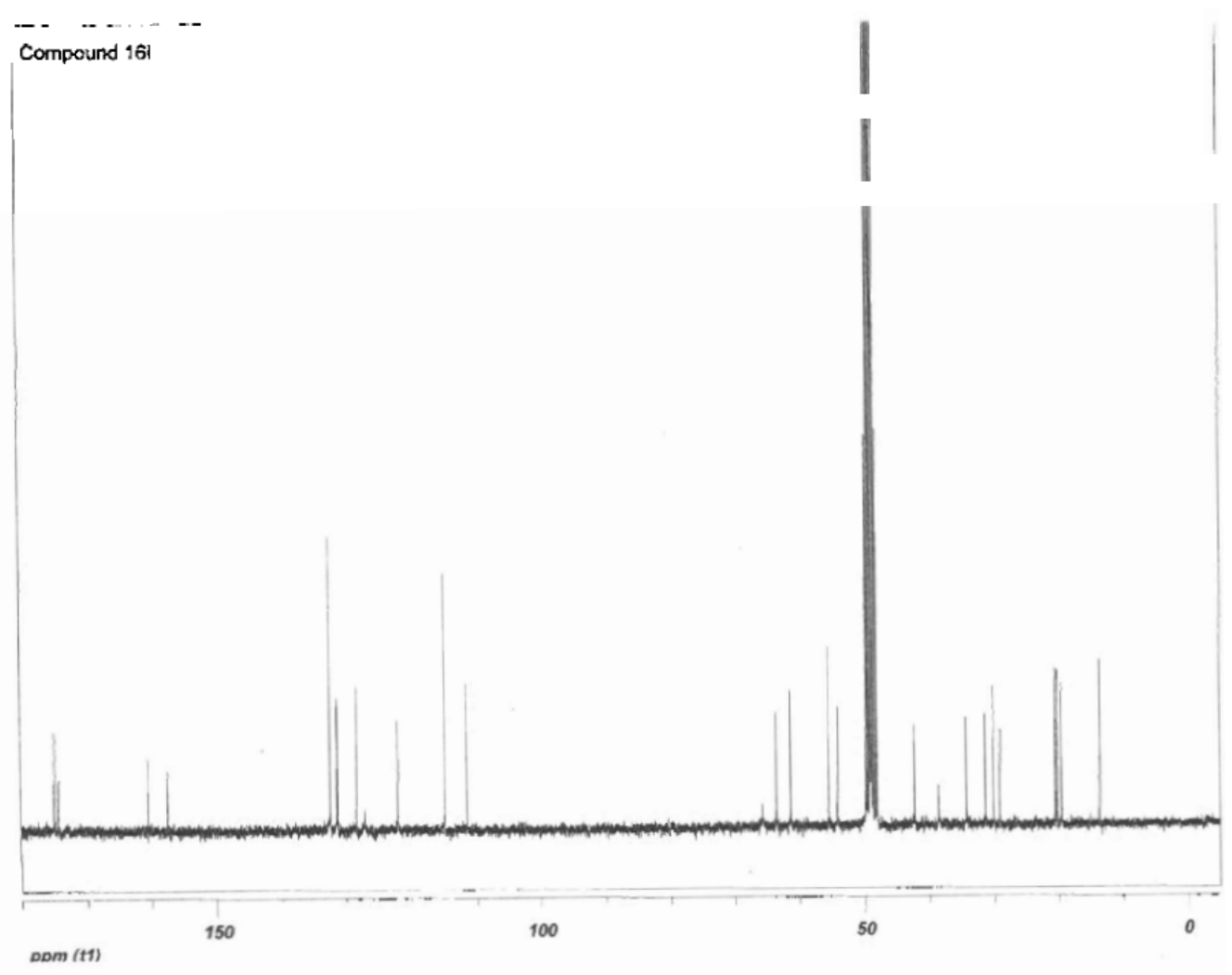



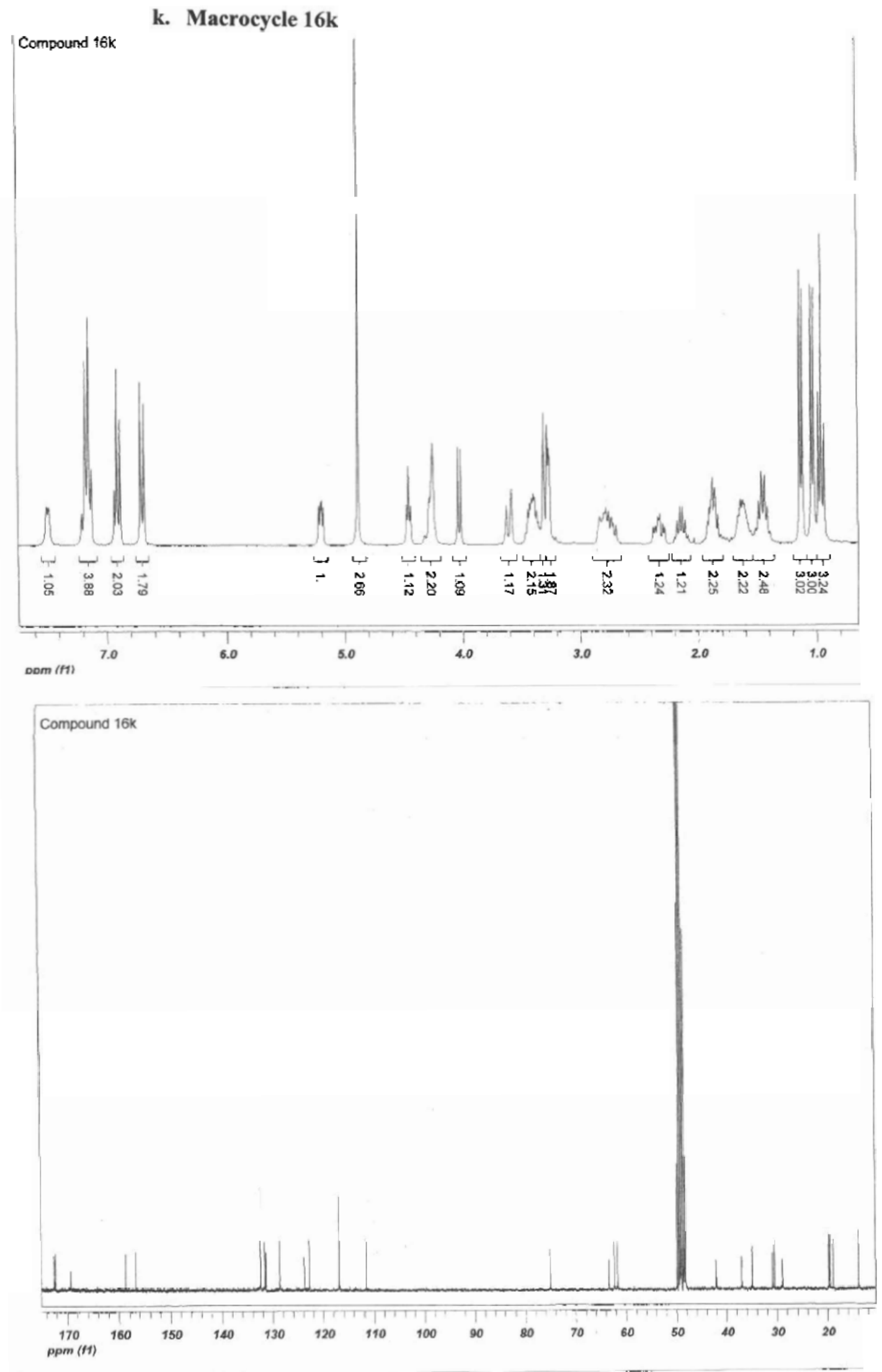
" Present address: MethylGene Inc., Montreal, QC, Canada.

Prof. Theo Peeters, Gut Hormone Lab, Gathuisberg O \& N, Leuven, Belgium. 